US Army Corps of Engineers ${ }_{\circledast}$ Engineer Research and Development Center

\title{
ERD@
}

Strategic Environmental Research and Development Program (SERDP)

Preparative, Extraction, and Analytical Methods for Simultaneous Determination of Legacy and Insensitive Munition (IM) Constituents in Aqueous, Soil or Sediment, and Tissue Matrices

Rebecca A. Crouch, Jared C. Smith, Bobbi S. Stromer,

Christian T. Hubley, Samuel Beal, Guilherme R. Lotufo, Afrachanna D. Butler, Michelle T. Wynter, Dale A. Rosado, Amber L. Russell, Jessica G. Coleman, Jay L. Clausen, and Anthony J. Bednar

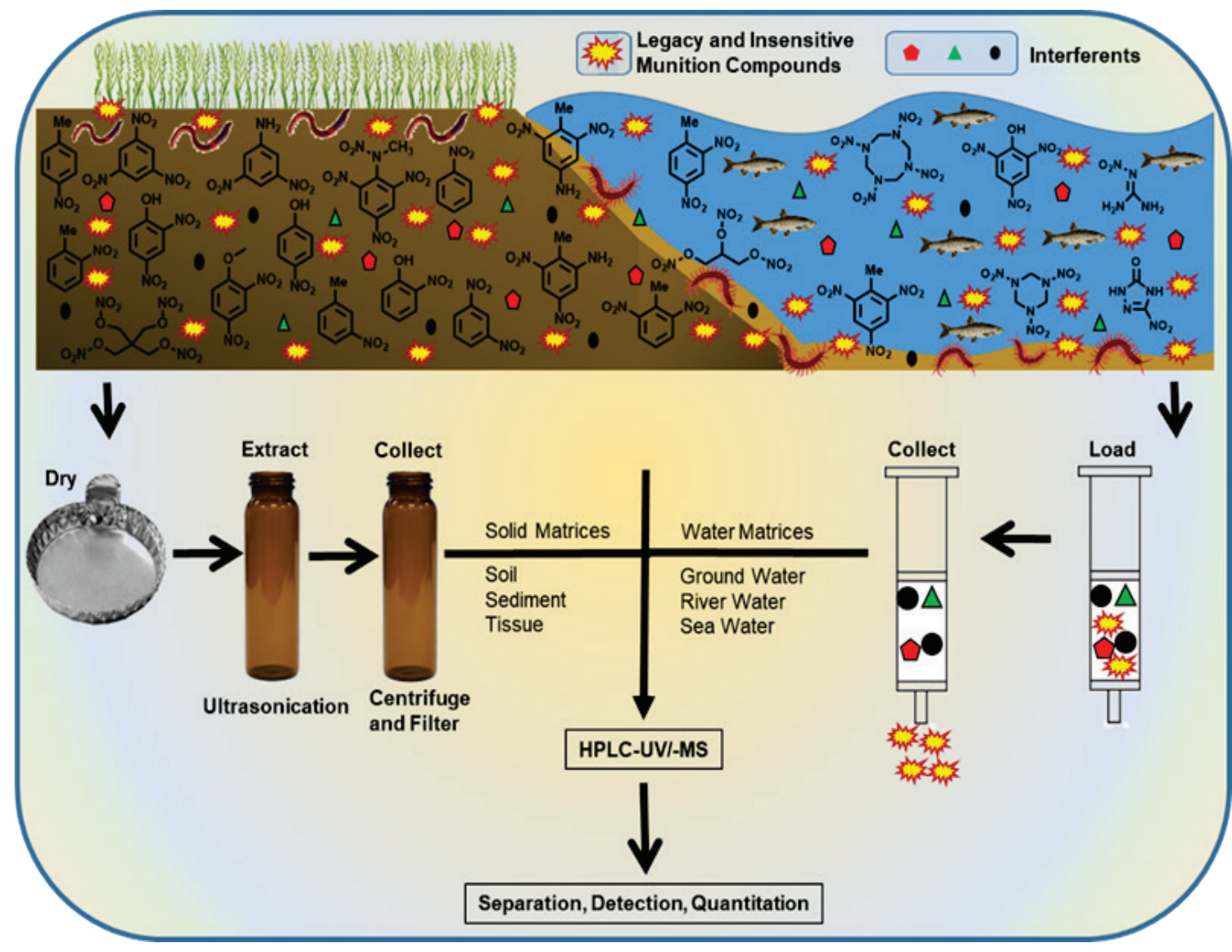


The US Army Engineer Research and Development Center (ERDC) solves the nation's toughest engineering and environmental challenges. ERDC develops innovative solutions in civil and military engineering, geospatial sciences, water resources, and environmental sciences for the Army, the Department of Defense, civilian agencies, and our nation's public good. Find out more at www.erdc.usace.army.mil.

To search for other technical reports published by ERDC, visit the ERDC online library at https://erdclibrary.on.worldcat.org/discovery. 


\section{Preparative, Extraction, and Analytical Methods for Simultaneous Determination of Legacy and Insensitive Munition (IM) Constituents in Aqueous, Soil/Sediment, and Tissue Matrices}

Rebecca A. Crouch, Jared C. Smith, Bobbi S. Stromer, Christian T. Hubley, Guilherme R. Lotufo, Afrachanna D. Butler, Michelle T. Wynter, Dale A. Rosado, Amber L. Russell, Jessica G. Coleman, and Anthony J. Bednar

Environmental Laboratory

US Army Engineer Research and Development Center 3909 Halls Ferry Road

Vicksburg, MS 39180-6199

Samuel Beal and Jay L. Clausen

Cold Regions Research and Engineering Laboratory US Army Engineer Research and Development Center 72 Lyme Road

Hanover, NH 03755-1290

Final report

Approved for public release; distribution is unlimited.

Prepared for Strategic Environmental Research and Development Program (SERDP) Alexandria, VA 22350-3605 


\section{Abstract}

No standard method exists for determining levels of insensitive munition (IM) compounds in environmental matrices. This project resulted in new methods of extraction, analytical separation and quantitation of 17 legacy and 7 IM compounds, daughter products of IM, and other munition compounds absent from USEPA Method 8330B. Extraction methods were developed for aqueous (direct-injection and solid-phase extraction [SPE]), soil, sediment, and tissue samples using laboratory-spiked samples. Aqueous methods were tested on 5 water sources, with 23 of 24 compounds recovered within DoD QSM Ver5.2 limits. New solvent extraction (SE) methods enabled recovery of all 24 compounds from 6 soils within QSM limits, and a majority of the 24 compounds were recovered at acceptable levels from 4 tissues types. A modified chromatographic treatment method removed analytical interferences from tissue extracts. Two orthogonal high-performance liquid chromatographyultraviolet (HPLC-UV) separation methods, along with an HPLC-mass spectrometric (HPLC-MS) method, were developed. Implementing these new methods should reduce labor and supply costs by approximately $50 \%$, requiring a single extraction and sample preparation, and 2 analyses rather than 4. These new methods will support environmental monitoring of IM and facilitate execution of risk-related studies to determine longterm effects of IM compounds.

DISCLAIMER: The contents of this report are not to be used for advertising, publication, or promotional purposes. Citation of trade names does not constitute an official endorsement or approval of the use of such commercial products. All product names and trademarks cited are the property of their respective owners. The findings of this report are not to be construed as an official Department of the Army position unless so designated by other authorized documents. 


\section{Contents}

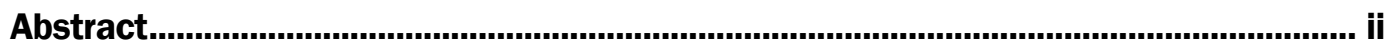

Figures and Tables................................................................................................... iv

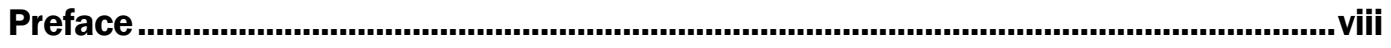

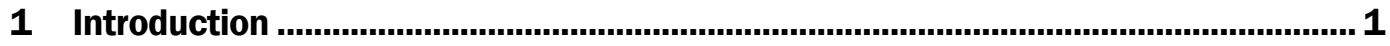

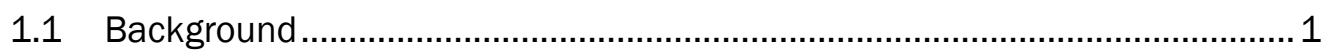

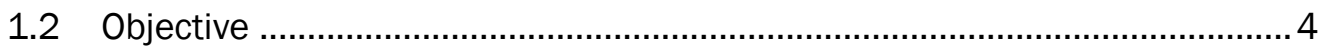

1.3 Technical approach .............................................................................. 4

1.4 Benefits and implications for future research and implementation ..............6

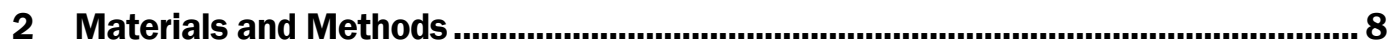

2.1 Primary HPLC-UV method ......................................................................... 8

2.2 Secondary high-performance liquid chromatography-ultraviolet

(HPLC-UV) method .......................................................................................... 10

2.3 High-performance liquid chromatography-mass spectrometric

(HPLC-MS) method ................................................................................... 12

2.4 Method for preparation of waters for direct-injection analysis ......................16

2.5 Solid-phase extraction (SPE) method for waters .......................................16

2.6 Solvent extraction (SE) method for soils .................................................. 17

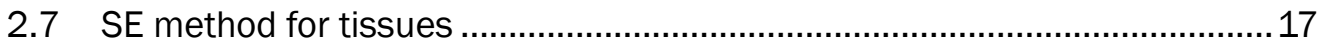

2.8 Chromatographic interference reduction method for tissue extracts ......... 18

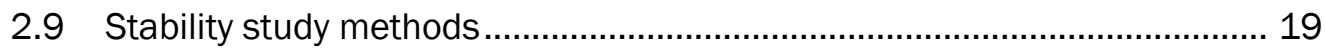

2.10 Interlaboratory batch analysis methods ............................................ 20

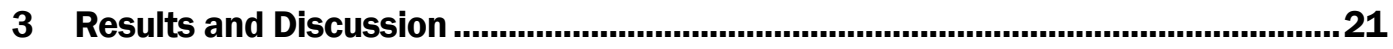

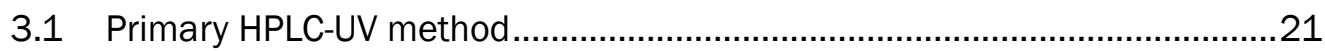

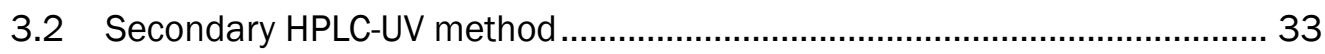

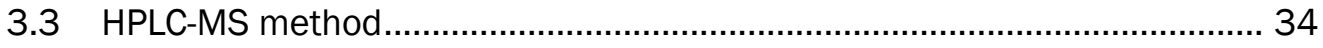

3.4 Method for preparation of waters for direct-injection analysis .......................37

3.5 SPE method for waters......................................................................... 40

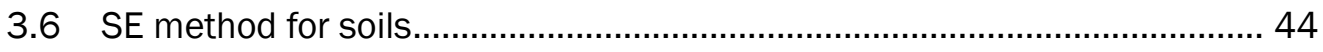

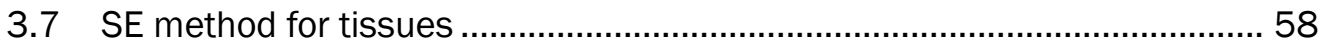

3.8 Chromatographic interference reduction method for tissue extracts .........60 60

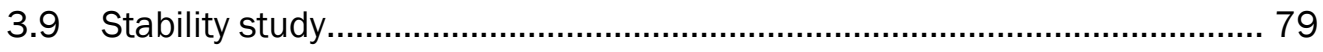

3.10 Interlaboratory batch analysis .......................................................... 86

4 Conclusions and Implications for Future Research and Implementation ..............92

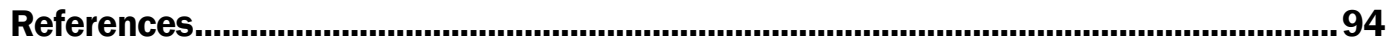

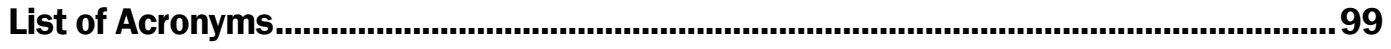




\section{Figures and Tables}

\section{Figures}

Figure 1. HPLC chromatograms of a mixed standard containing $5 \mathrm{mg} / \mathrm{L}$ of 24 legacy and IM compounds and 2 surrogates analyzed by the developed primary HPLC-UV method (210 nm: bottom line; $254 \mathrm{~nm}$ : middle line; $315 \mathrm{~nm}$ : top line). (Retention times are listed in Table 5.)

Figure 2. HPLC chromatograms of a mixed standard containing $10 \mathrm{mg} / \mathrm{L}$ of 24 legacy and IM compounds and 2 surrogates analyzed by the developed secondary HPLC-UV method (210 nm: bottom line; $254 \mathrm{~nm}$ : middle line; $315 \mathrm{~nm}$ : top line). (Retention times are listed in Table 3.)

Figure 3. Total ion chromatogram (TIC) for a mixed standard containing $10 \mathrm{mg} / \mathrm{L}$ of 24 legacy and IM compounds and 2 surrogates analyzed by the developed confirmatory HPLC-MS scan mode method. (Retention times are listed in Table 4.)

Figure 4. Previous HPLC methods used for munition compound determinations, including (a) current USEPA Method 8330B employed at the Engineer Research and Development Center-Environmental Laboratory (ERDC-EL) for HPLC-UV analysis of legacy compounds, (b) method developed at ERDC-EL for HPLC-MS analysis of insensitive munition (IM) compounds (Russell et al. 2014), (c) current method employed at ERDC-EL for HPLC-UV analysis of IM compounds, and (d) primary column HPLC-UV method developed for simultaneous analysis of legacy and IM compounds for SERDP ER-2722.

Figure 5. Effect of varying the solvent gradient initial $\mathrm{MeOH}$ from $2 \%$ to $15 \%$, while holding the $0.1 \% \mathrm{TFA} /$ water and ACN constant, using $5 \mathrm{mg} / \mathrm{L}$ mixed standard containing all 24 compounds of interest and 1,2-DNB surrogate prepared in 50/50 $\mathrm{MeOH} /$ water.

Figure 6 . Effect of varying the solvent gradient isocratic $0.1 \%$ TFA/water from $2 \%$ to $15 \%$, while setting the initial $\mathrm{MeOH}$ at $3 \%$ and holding $\mathrm{ACN}$ constant at $5 \%$, using $5 \mathrm{mg} / \mathrm{L}$ mixed standards containing all 24 compounds of interest and 1,2DNB surrogate prepared in 50/50 MeOH/water. (a) Effect on NQ and NTO, (b) Effect on PA and 2,4-DNP retention times ( $\mathrm{min}$ ) and peak shapes.

Figure 7. Effect of varying the solvent gradient isocratic $\% \mathrm{ACN}$ from $5 \%$ to $8 \%$, while setting the initial $\% \mathrm{MeOH}$ at 3\% and holding $\% 0.1 \% \mathrm{TFA} /$ water constant at $3 \%$, using $5 \mathrm{mg} / \mathrm{L}$ mixed standards containing all 24 compounds of interest and 1,2-DNB surrogate prepared in 50/50 MeOH/water. (a) Effect on NQ and NTO, (b) Effect on middle- and late-eluting compounds.

Figure 8. Effect of introducing an ACN gradient from 6\%-20\% over the period 28-44 min. Red: HPLC-UV chromatogram resulting from ACN gradient method; yellow: ACN composition (\%); blue: HPLC-UV chromatogram resulting from $6 \%$ isocratic $\mathrm{ACN}$ (without ACN gradient)

Figure 9. Effect of varying the sample solvent composition $\% \mathrm{MeOH}$ from $0 \%$ to $100 \%$, using the developed primary HPLC-UV method to analyze $5 \mathrm{mg} / \mathrm{L}$ mixed standards containing all 24 compounds of interest and 1,2-DNB surrogate prepared with indicated $\mathrm{MeOH} /$ water solvent ratios. (a) Effect on NQ and NTO, (b) effect on middle- and late-eluting compounds. 
Figure 10. Secondary HPLC-UV method solvent gradient scheme developed for simultaneous confirmatory analysis of legacy and IM compounds.

Figure 11. HPLC-MS TIC acquired by SIM mode method. SIM window start times are indicated by dotted lines, and SIM group numbers are noted above the plot area. (Retention times are listed in Table 6.)

\section{Tables}

Table 1. Primary high-performance liquid chromatography-ultraviolet (HPLC-UV) separation solvent gradient scheme and other method conditions. (*or $0.25 \%$ $\mathrm{FA} /$ water)

Table 2. Secondary HPLC-UV separation solvent gradient scheme and other method conditions. (*or 0.25\% FA/water).

Table 3. Retention times ( $\mathrm{min}$ ) for the 24 compounds of interest and 2 surrogates, analyzed by the secondary HPLC-UV method.

Table 4. Spray chamber and detector parameters for the developed HPLC-MS scan mode method.

Table 5. Retention times ( $\mathrm{min}$ ), ion masses ( $\mathrm{m} / \mathrm{z}$ ), and identities obtained for mixed standard containing 24 legacy and IM compounds and 2 surrogates using the developed HPLC-MS scan mode method.

Table 6. Retention times (min), method detection limits (MDLs) and linear dynamic range (LDR) upper limits (ULs) for the 24 compounds of interest and 2 surrogates, determined in direct-injection water (Est. MDL), reagent water that underwent SPE preconcentration, and Ottawa sand that underwent SE, analyzed by the primary HPLC-UV method.

Table 7. Selective-ion monitoring (SIM) windows developed from UV peak retention times $(\mathrm{min})$ and ion masses $(\mathrm{m} / \mathrm{z}$ ) observed using the developed scan mode method.

Table 8. Characteristic properties of five water sources used in interlaboratory batch studies. (AVG = average; SD = standard deviation)

Table 9. Recoveries (\%) for five water samples acidified using $2 \% \mathrm{HCl} / \mathrm{MeOH}$ and analyzed by direct injection without undergoing SPE. (AVG = average; SD = standard deviation)

Table 10. Compound recoveries from laboratory-spiked reagent water samples using individual SPE cartridges for extraction/preconcentration of the 24 compounds of interest and 1,2-DNB surrogate.

Table 11. Compound recoveries (\%) from laboratory-spiked reagent water samples using stacked SPE cartridges for extraction/preconcentration of the 24 compounds of interest and 1,2-DNB surrogate.

Table 12. Recoveries (\%) from spiked ASTM fat clay using either $\mathrm{MeOH}$ or ACN to perform SE for either $1 \times 18 \mathrm{~h}$ or $2 \times 9 \mathrm{~h}$ ultrasonication periods.

Table 13. Recoveries (\%) from spiked ASTM fat clay using several multi-stage SE sequences with ultrasonication for either $3 h-3 h-4 h, 6 h-14 h$, or $8 h-8 h$ with various solvent combinations.

Table 14. Characteristic properties for six soils used in SE method development and testing for soils. 
Table 15. Recoveries (\%) from six laboratory-spiked soils using an $18 \mathrm{~h}$ ultrasonication period with $\mathrm{ACN}, \mathrm{MeOH}, 50 / 50 \mathrm{MeOH}$ /water, or water.

Table 16. Recoveries (\%) from six laboratory-spiked soils using four different twoor three-stage ultrasonication sequences. (A) $6 \mathrm{~h} \mathrm{MeOH-14-h} \mathrm{MeOH/water;} \mathrm{(B)} 6$ $\mathrm{h} \mathrm{MeOH}-14 \mathrm{~h}$ water; (C) $3 \mathrm{~h} \mathrm{MeOH}-3 \mathrm{~h}$ water-14 h water; (D) $3 \mathrm{~h} \mathrm{MeOH}-3 \mathrm{~h}$ $\mathrm{MeOH}-14 \mathrm{~h}$ water. (AVG = average; $\mathrm{SD}=$ standard deviation).

Table 17. Recoveries (\%) from four laboratory-spiked tissues using one $18 \mathrm{~h}$ ultrasonic extraction with $\mathrm{MeOH}$, prior to undergoing chromatographic treatment to reduce analytical interference. (AVG = average; $S D=$ standard deviation)

Table 18. Recoveries (\%) from laboratory-spiked polychaete worm tissue $\mathrm{MeOH}$ extracts following either neutral alumina or florisil chromatographic treatment for interference reduction. (AVG = average; $\mathrm{SD}=$ standard deviation).

Table 19. Recoveries (\%) from laboratory-spiked tissues $\mathrm{MeOH}$ extract, following no interference reduction treatment, or treatment with either neutral alumina or florisil. (AVG = average; $S D=$ standard deviation).

Table 20. Recoveries (\%) from postextraction spiked fathead minnow tissue $\mathrm{MeOH}$ extract, following five different chromatographic treatment options for matrix-related analytical interference reduction. (AVG = average; SD = standard deviation).

Table 21. Recoveries (\%) from postextraction spiked earthworm tissue $\mathrm{MeOH}$ extract, following five different chromatographic treatment options for matrixrelated analytical interference reduction. (AVG = average; $S D=$ standard deviation).

Table 22. Recoveries (\%) from postextraction spiked polychaete worm tissue $\mathrm{MeOH}$ extract, following five different chromatographic treatment options for matrix-related analytical interference reduction. (AVG = average; $S D=$ standard deviation)

Table 23. Recoveries (\%) from postextraction spiked ryegrass tissue $\mathrm{MeOH}$ extract, following five different chromatographic treatment options for matrixrelated analytical interference reduction. (AVG = average; $S D=$ standard deviation).

Table 24. Recoveries (\%) from pre-extraction spiked tissue $\mathrm{MeOH}$ extracts, following chromatographic treatment with silica gel for matrix-related analytical interference reduction. (AVG = average; $S D=$ standard deviation).

Table 25. Extraction hold-time stability for laboratory-spiked reagent water samples over seven days. (AVG = average; SD = standard deviation)

Table 26. Analysis hold-time stability for laboratory-spiked reagent water samples over 40 days. (AVG = average; $\mathrm{SD}=$ standard deviation).

Table 27. Extraction hold-time stability for three laboratory-spiked soil samples over 14 days. (AVG = average; SD = standard deviation)

Table 28. Analysis hold-time stability for three laboratory-spiked soil samples over 40 days. (AVG = average; $S D=$ standard deviation $)$

Table 29. Cross-laboratory batch analysis tests using five different water sources and the SPE method developed under SERDP ER-2722. (AVG = average; SD = standard deviation) 
Table 30. Cross-laboratory batch analysis tests using six different soil sources and the two-stage SE method developed under SERDP ER-2722. (AVG = average; $\mathrm{SD}=$ standard deviation) ..............................................................................................90 


\section{Preface}

This study was conducted for the Strategic Environmental Research and Development Program (SERDP) under MIPR W74RDV70604798 under Project ER-2722, "Development and Optimization of Analytical Methods for Simultaneous Determination of IM and Legacy Explosive Compounds". The technical monitor was Dr. Elizabeth A. Ferguson.

The work was performed by the Environmental Chemistry Branch of the Environmental Processes Division, US Army Engineer Research and Development Center, Environmental Laboratory (ERDC-EL). At the time of publication, Amber L. Russell was Chief, Warren P. Lorentz was Chief, and Elizabeth Ferguson was the Technical Director for Military Environmental Engineering and Sciences. The Deputy Director of ERDCEL was Dr. Jack E. Davis and the Director was Dr. Edmond J. Russo Jr.

Special thanks to Dr. Stacy J. Jones for early method development technical assistance. Special thanks to Ms. Hannah R. Peel for assistance with HPLC data processing. Special thanks to Ms. Charolett A. Hayes, Ms. Kayley C. Watson, and Mr. Andrew L. Bray for assistance with supplies procurement and sample matrix characteristic analysis. Special thanks to Ms. Kayley C. Watson and Ms. Kelli L. Hartman for assistance with shipping samples for analysis and receiving samples and supplies.

COL Teresa A. Schlosser was the Commander of ERDC, and Dr. David W. Pittman was the Director.

Portions of this report have been modified and reused with permission from Rebecca A. Crouch, Jared C. Smith, Bobbi S. Stromer, Christian T. Hubley, Samuel Beal, Guilherme R. Lotufo, Afrachanna D. Butler, Michelle T. Wynter, Amber L. Russell, Jessica G.

Coleman, Katrinka M. Wayne, Jay L. Clausen, and Anthony J. Bednar, 2020, "Methods for Simultaneous Determination of Legacy and Insensitive Munition (IM) Constituents in Aqueous, Soil/Sediment, and Tissue Matrices" in Talanta 217 (1 September 2020): 1-11. https://doi.org/10.1016/j.talanta.2020.121008. Copyright 2020 Elsevier. 


\section{Introduction}

\subsection{Background}

No standard method currently exists for analyzing insensitive munition (IM) compounds in environmental matrices (with or without concurrent legacy compounds). Lacking established methods, contract and research laboratories either do not measure IM compounds at all; quantify some, but not all, using US Environmental Protection Agency (USEPA) Method 8330B (USEPA 2006) developed for legacy compounds (leading to inaccuracies for certain IM compounds and degradation products [Felt et al. 2016]); or use methods originally developed for neat materials with no proven performance metrics.

IM compounds are high-energy compounds that, while designed to match the performance of legacy materials, are less likely to detonate when exposed to unintended stimuli such as shock, heat, and adjacent detonating munitions (Barrie 2013). The development of IM began in the 1980 os upon review of several unintended detonations at US Army facilities as a means to improve soldier safety and reduce resource loss (Newman 2010). The primary goal of the IM Program is to oversee the development and production of safer alternatives to replace 2,4,6-trinitrotoluene (TNT) and Composition-B (Comp-B) in US Military ordnance (Kiebler and Manz 2010). Comp-B contains TNT and hexahydro-1,3,5-trinitro-s-triazine (RDX). The compounds and formulations developed under the IM Program are required to meet certain criteria. They must be as effective as legacy munitions; they must show reduced sensitivity compared to legacy munitions; they must be inexpensive; and they must be scalable for production (Roos 2007). Of the numerous compounds and mixtures evaluated for use in IM formulations, three compounds-3-nitro-1,2,4triazol-5-one (NTO); nitroguanidine (NQ); and 2,4-dinitroanisole (DNAN)-hold the most promise as legacy replacements. IMX-101 (NTO, NQ, and DNAN) is the current frontrunner for replacement of TNT in US munitions packing (Picatinny Public Affairs 2010), and IMX-104 (NTO, DNAN, and RDX) is set to replace Comp-B (Mainiero 2015). Other compositions, such as PAX-21 (RDX, DNAN, and ammonium perchlorate) and PAX-41 (DNAN and RDX), have already seen use in theater (Fung et al. 2012). 
Though care may be taken to follow strict munition handling guidelines, unintentional release of munition compounds into the environment could occur at any point during the manufacturing, testing, operation, or demilitarization processes. Contamination could occur due to leaky plumbing at manufacturing facilities, or at wastewater treatment plants, or from unintentional spills during transport. On the battlefield and on testing ranges, unconsumed munition compounds are dispersed at the target and at the point from which the shot was fired (from propellant) as small particles (Jenkins et al. 2001; Jenkins et al. 2005; Jenkins et al. 2006; Pennington et al. 2001, Pennington et al. 2002, Pennington et al. 2003, Pennington et al. 2004, Pennington et al. 2005, Pennington et al. 2006; Taylor et al. 2004). Corrosion and leakage of unexploded ordnance (UXO) can be a major long-term point source on impact areas (Brannon et al. 2000; Chendorain, Stewart, and Packer 2005).

Contamination found on munitions ranges is complex. The various chemical and physical properties of each munition compound, their transformation products, and the interferences arising from the environmental matrix make extraction and quantitation a challenge. Two factors complicate the assessment of environmental impacts from munitions contamination. First, new IM formulations will be used on training ranges where legacy munition contamination may be present. Second, daughter products of IM components, such as 2-/4-nitrophenol (2-/4-NP) or 2,4-dinitrophenol (2,4-DNP) (Hawari et al. 2015) from the degradation of DNAN, appear as IM compounds degrade. Aminotoluenes and nitrotoluenes from the degradation of TNT are examples of degradation products that might also be present if legacy munitions had previously been used at the site (Walsh and Jenkins 1990). Other legacy munitions, such as picric acid (PA) may also be present on training ranges but are not included in USEPA Method 8330 (Goerlitz 1979).

Current high-performance liquid chromatography (HPLC)-and gas chromatography (GC)-based analytical methods require preconcentration by solid-phase extraction (SPE) prior to analysis in order to achieve sub$\mu \mathrm{g} / \mathrm{L}^{1}$ detection limits in water samples. While methods of extracting legacy munitions from water by SPE have been standardized, and several

1. For a full list of the spelled-out forms of the units of measure used in this document, please refer to US Government Publishing Office Style Manual, 31st ed. (Washington, DC: US Government Publishing Office, 2016), 248-52, https://www.govinfo.gov/content/pkg/GPO-STYLEMANUAL-2016/pdf/GPOSTYLEMANUAL-2016.pdf. 
SPE methods are available for the extraction of nitrophenols, only one has been developed for NTO (Walsh 2016). To date, no unified SPE method has been developed that allows for coextraction of NTO, NQ, DNAN, PA, 2,4-DNP, and 2-/4-NP. Lack of such a method means that detection limits are significantly elevated, because IM-containing waters must undergo direct-injection analysis by HPLC.

The traditional acetonitrile (ACN) extraction method for explosives in soils described in USEPA Method $8330 \mathrm{~B}$ results in poor extraction efficiency of NTO, NQ, PA, 2,4-DNP, and 2-/4-NP. The compounds are only slightly soluble in acetonitrile but have relatively high solubility in water at $13 \mathrm{~g} / \mathrm{L}$ for NTO, $2.6 \mathrm{~g} / \mathrm{L}$ for NQ, $17.6 \mathrm{~g} / \mathrm{L}$ for PA, $5.6 \mathrm{~g} / \mathrm{L}$ for 2,4-DNP, $2.1 \mathrm{~g} / \mathrm{L}$ for 2-NP, and $16 \mathrm{~g} / \mathrm{L}$ for 4-NP. Furthermore, PA, NTO, and 2,4-DNP exist as anions at neutral $\mathrm{pH}$ due to their acidic nature, with $\mathrm{pKa}=0.38,3.76$, and 4.11, respectively. Alternatively, NQ (pKa 12.2) can exist as either a nitroimine (predominant at environmental $\mathrm{pH}$ ) or nitroamine, and at very low $\mathrm{pH}$ could become protonated to form a cation (De Vries and St. ClairGantz 1954; Kaplan, Cornell, and Kaplan 1982). DNAN is the exception of the IM compounds, with water solubility comparable to TNT (approximately $200 \mathrm{mg} / \mathrm{L}$ ) (Lide 2005). Indeed, DNAN has been extracted via the standard SPE procedure outlined in USEPA Method 3535 (USEPA 2007).

HPLC separations, coupled with ultraviolet (UV) absorbance or mass spectrometric (MS) detection and quantitation, are the gold standard for analysis of munition compounds (USEPA 2006). Many munition compounds are nitroaromatics (for example, nitrotoluenes and nitrobenzenes) or nitramines (for example, RDX) and are analyzed using USEPA Method 8330. Other energetic compounds, including NTO, DNAN, NQ, and PA, can also be determined using HPLC separations, though the mobile and stationary phases may be modified from the conditions reported in USEPA Method 8330B (USEPA 1996; Goerlitz 1979; Russell et al. 2014). The chemical properties of some of these compounds preclude direct application of the extraction, preconcentration, and analysis methods described in USEPA Methods 3535 and $8330 \mathrm{~B}$ protocols without modification. Therefore, when analysis of samples containing IM and legacy compounds is required, multiple analytical procedures would have to be employed, leading to increased costs and delays in data availability. 
Much research is underway to determine the effects of NTO, DNAN, and NQ in the environment. The lack of uniform methods for extraction of munition compounds in water, soil, and tissue is a barrier to determining the long-term environmental impact of IM compounds. The wide-ranging solubilities and ionic properties of NTO, NQ, DNAN, 2,4-DNP, 2-/4-NP, and legacy munition compounds necessitated the development and optimization of methods to effectively extract or extract and preconcentrate-denoted as extract/(preconcentrate) throughout this technical report-all of the IM and legacy compounds studied. This work fills current gaps in energetics determination methodology by developing a direct-injection and SPE method for waters, solvent extraction (SE) methods for soils and tissues, and two HPLC-UV and one HPLC-MS method for analysis of IM, IM transformation products, and legacy munition compounds. The implementation of these methods for simultaneous determination of IM and legacy munition compounds should lead to resource and labor cost savings, with a minimal increase in environmental monitoring efforts and no modification to existing samplecollection procedures.

\subsection{Objective}

The primary objective of this project was to fulfill the requirements of SERDP SON ERSON-17-02 by developing new methods of extraction, preconcentration, and analytical separation and quantitation of 17 legacy and 7 IM compounds, daughter products of IM, and other munition compounds absent from USEPA Method 8330B. The goal was to produce a single standardized method for simultaneous analysis of legacy and IM compounds in environmental matrices. Two HPLC-UV and one HPLC-MS methods were developed, as well as extraction methods for waters (directinjection and SPE), soils (two-stage SE), and tissues (one-stage SE). An analytical interference reduction procedure was also developed for tissues.

\subsection{Technical approach}

HPLC methods were developed for simultaneous separation, detection, and quantitation of 24 legacy and IM compounds of interest and 2 surrogates. Primary- and secondary-column HPLC-UV methods, as well as a confirmatory HPLC-MS method, were developed by the Environmental Laboratory (EL) at the US Army Corps of Engineers (USACE) Engineer Research and Development Center (ERDC), adapted from existing methods (USEPA 2006; Russell et al. 2014). The compounds of interest 
were the 17 legacy compounds included in USEPA Method 8330B (USEPA 2006) and 7 IM compounds, daughter products, and others absent from USEPA Method 8330B, specifically, NQ, NTO, PA, DNAN, 2,4-DNP, 2-NP, and 4-NP. The linear dynamic ranges (LDRs), method detection limits (MDLs), and matrix effects for IM compounds, IM daughter products, and legacy munition compounds were studied using the developed extraction/(preconcentration) and analytical methods in aqueous and solid matrices.

SPE is a method for extraction and preconcentration of energetic compounds from environmental water samples in both USEPA Method 8330B and internal ERDC-EL IM methods. An SPE method was developed to extract and preconcentrate all 24 compounds of interest (and 2 surrogates) by evaluating a series of cation-exchange, anion-exchange, reverse-phase (polymeric and traditional C-18), and activated carbonbased SPE cartridges. Methods developed using reagent water samples were applied to four additional water matrices: (1) tap water-Vicksburg Municipal Water; (2) ground water-well water from Rayville, Louisiana; (3) river water-Yazoo River near Vicksburg, Mississippi; (4) sea waterHouston Shipping Channel. Water characterization, including pH, TOC, and TDS appear in Table 8 (section 3.4) The developed SPE method efficiently extracted all 24 compounds of interest and 2 surrogates within acceptable Department of Defense (DoD) Quality Systems Manual (QSM) Ver5.2 limits, except NQ (approximately 50\% recovery), from each water type, with slight $\mathrm{pH}-$ related variability, particularly with NTO.

Current USEPA Method 8330B solvent extraction methods were modified to enable extraction of all 24 legacy and IM compounds of interest (and 2 surrogates) from soil samples by adjusting the solvent system and using a two-stage extraction procedure. The developed SE method efficiently extracted all 24 compounds of interest and 2 surrogates within acceptable DoD QSM Ver5.2 limits, using six different soil sources: (1) ASTM fat clay-CH-1; (2) Aberdeen clay-Aberdeen, Maryland; (3) Jefferson clayMadison, Indiana; (4) Memphis silt-Memphis, Tennessee; (5) Ft. Riley clay-Riley, Kansas; (6) Yuma sand-Yuma, Arizona. All six soils showed a wide range of organic matter, $\mathrm{pH}$, and other properties (listed in Table 14, section 3.6).

A tissue extraction method was also developed by slight modification to existing USEPA Method 8330B processes, with the majority of the 24 
compounds and 2 surrogates being extracted within acceptable DoD QSM Ver5.2 limits via a single $18 \mathrm{~h} \mathrm{MeOH}^{2}$ (rather than ACN) extraction. Four different tissue matrices were tested, including (1) earthworms (Eisenia fetida, soil-dwelling invertebrate); (2) fathead minnows (Pimephales promelas, freshwater vertebrate); (3) polychaete worms (Alitta virens, marine invertebrate); and (4) perennial ryegrass (Lolium perenne, perennial plant). Varying degrees of analytical interferences arising from coextracted nontarget matrix components were observed for each tissue type, with the most interference occurring in earthworm tissue. A chromatographic interference reduction method, using common organic laboratory chromatography materials, was developed to remove these matrix-associated analytical interferences.

Stability studies were carried out using laboratory-spiked reagent water and three laboratory-spiked soils (Riley, Yuma, and ASTM fat clay) to verify whether current standard pre- and postextraction hold times of 7/14 days and 40 days, respectively, for semivolatile organics (USEPA 2014) would remain valid for mixtures of the 24 legacy and IM compounds and 2 surrogates. Samples were stored in triplicate under three different conditions: (1) cold/dark ( $4^{\circ} \mathrm{C} /$ amber vials); (2) room temperature/dark $\left(25^{\circ} \mathrm{C} /\right.$ amber vials); and (3) room temperature/light $\left(25^{\circ} \mathrm{C} /\right.$ clear vials) in order to distinguish photo- versus thermal-related degradation of each compound. In addition, the developed extraction and analysis (primary HPLC-UV) methods were applied to laboratory-spiked water (five samples) and soil (six samples) for verification by inter-laboratory testing at ERDC-EL and ERDC Cold Regions Research and Engineering Laboratory (CRREL). For these tests, samples were extracted and analyzed within current standard hold times for semivolatile organics.

\subsection{Benefits and implications for future research and implementation}

The development of these extraction and analysis methods to simultaneously analyze environmentally copresent legacy and IM compounds was necessary to enable future monitoring of co-occurring components at firing ranges, demilitarization facilities, manufacturing facilities, and environmental sites, where munitions are tested, produced,

\footnotetext{
2. For a full list of the spelled-out forms of the chemical elements used in this document, please refer to US Government Publishing Office Style Manual, 31st ed. (Washington, DC: US Government Publishing Office, 2016), 265, https://www.govinfo.gov/content/pkg/GPO-STYLEMANUAL2016/pdf/GPO-STYLEMANUAL-2016.pdf.
} 
and detected (Felt et al. 2013; Walsh et al. 2014). Currently, separate extraction procedures must be carried out to extract legacy and IM compounds. Furthermore, separate primary and secondary analytical methods must be used to quantify legacy and IM compounds. It is estimated that the simultaneous analysis of IM and legacy compounds using the developed primary and secondary HPLC-UV methods may reduce total analysis time by approximately $50 \%$ versus using four different analytical methods, as the previous process required. In addition, the labor and supply cost savings due to coextraction and sample preparation is at least $50 \%$, as only a single extraction procedure and analytical sample preparation are required, versus up to four (including confirmation analyses and associated quality control [QC] samples), since the sample preparation for the primary and secondary methods are the same. Overall, these savings will lead to reduced laboratory costs and more rapid results acquisition. The current work will continue under ESTCP ER19-D1-5078 (Validation of Sample Extraction and Analysis Techniques for Simultaneous Determination of Legacy and Insensitive Munitions [IM] Constituents), to validate the methods described herein.

Furthermore, the products of this work will contribute to the ability to conduct fate and transport studies for IM compounds by providing a standardized method for quantitation of IM and legacy materials needed to determine long-term effects. 


\section{Materials and Methods}

\subsection{Primary HPLC-UV method}

The HPLC-UV and -MS methods developed under SERDP ER-2722 were modified from existing methods and established laboratory techniques. Previously developed (Russell et al. 2014) and currently used explosives analysis methods (USEPA 8330B, in-house IM method; see Figure 4, section 3.1) were used as a starting point and reference in the development of the primary and secondary HPLC-UV methods for SERDP ER-2722.

The primary HPLC-UV method for simultaneous separation and quantitation of 17 legacy and 7 IM compounds, daughter products, and other munition compounds not included in USEPA Method 8330B was developed by adapting previous methods. Method parameters and solvent gradient scheme are shown in Table 1. Method development was carried out using Phenomenex Synergi $4 \mu \mathrm{m}$ Hydro-RP, $80 \AA \AA$, $250 \times 4.6 \mathrm{~mm}$ HPLC columns. An optional Phenomenex SecurityGuard AQ C18 precolumn guard cartridge was included, which could extend column lifetimeespecially when analyzing samples containing complex environmental matrices. As indicated in Table 1, either a $0.1 \%$ TFA or $0.25 \%$ FA (v/v) solution in water can be used. (This was investigated during HPLC-MS method development [section 2.3], due to ion-suppression effects caused by TFA.) An example chromatogram is shown in Figure 1 (acquired using TFA). All chromatographic peaks were identified using individual reference standards.

The HPLC methods developed under Strategic Environmental Research and Development Program (SERDP) Environmental Restoration (ER)-2722 were adapted from a method originally developed for internal ERDC efforts funded by the Environmental Quality and Installations (EQI) program that investigated IM biogeochemistry. The SERDP ER-2722 project and previous EQI-funded efforts built on previously completed SERDP and Environmental Security Technology Certification Program (ESTCP) projects focused on legacy compounds (SERDP ER-1155, SERDP ER1481, and ESTCP ER-2000628). The current work will continue under ESTCP ER19-D15078 (Validation of Sample Extraction and Analysis Techniques for Simultaneous Determination of Legacy and Insensitive Munitions (IM) Constituents), to validate the methods described herein. The efforts undertaken for SERDP ER-2722 were carried out in coordination with those for SERDP ER-2724 (PI: Dr. Roman Kuperman). 
Table 1. Primary high-performance liquid chromatography-ultraviolet (HPLC-UV) separation solvent gradient scheme and other method conditions.

(*or $0.25 \% \mathrm{FA} /$ water)

\begin{tabular}{|c|c|c|c|c|}
\hline \multicolumn{6}{|l|}{$\begin{array}{l}\text { Total run time: } \\
\text { Column temperature: } \mathbf{2 5} \text {; C; Flow rate: } \mathbf{1 . 0} \mathbf{~ m L / m i n ; ~ I n j e c t i o n ~ v o l u m e : ~} 50 \mu \mathrm{L}\end{array}$} \\
\hline Time (min) & Reagent water (\%) & MeOH (\%) & $0.1 \%$ TFA/water (\%)* & ACN (\%) \\
\hline 0.00 & 89 & 3 & 3 & 5 \\
\hline 2.00 & 89 & 3 & 3 & 5 \\
\hline 2.20 & 52 & 40 & 3 & 5 \\
\hline 12.5 & 52 & 40 & 3 & 5 \\
\hline 19.0 & 57 & 35 & 3 & 5 \\
\hline 28.0 & 48 & 44 & 3 & 5 \\
\hline 32.0 & 48 & 44 & 3 & 5 \\
\hline 44.0 & 32 & 60 & 3 & 5 \\
\hline 44.1 & 89 & 3 & 3 & 5 \\
\hline 48.0 & 89 & 3 & 3 & \\
\hline
\end{tabular}

Figure 1. HPLC chromatograms of a mixed standard containing $5 \mathrm{mg} / \mathrm{L}$ of 24 legacy and IM compounds and 2 surrogates analyzed by the developed primary HPLC-UV method (210 nm: bottom line; $254 \mathrm{~nm}$ : middle line; $315 \mathrm{~nm}$ : top line). (Retention times are listed in Table 6.)

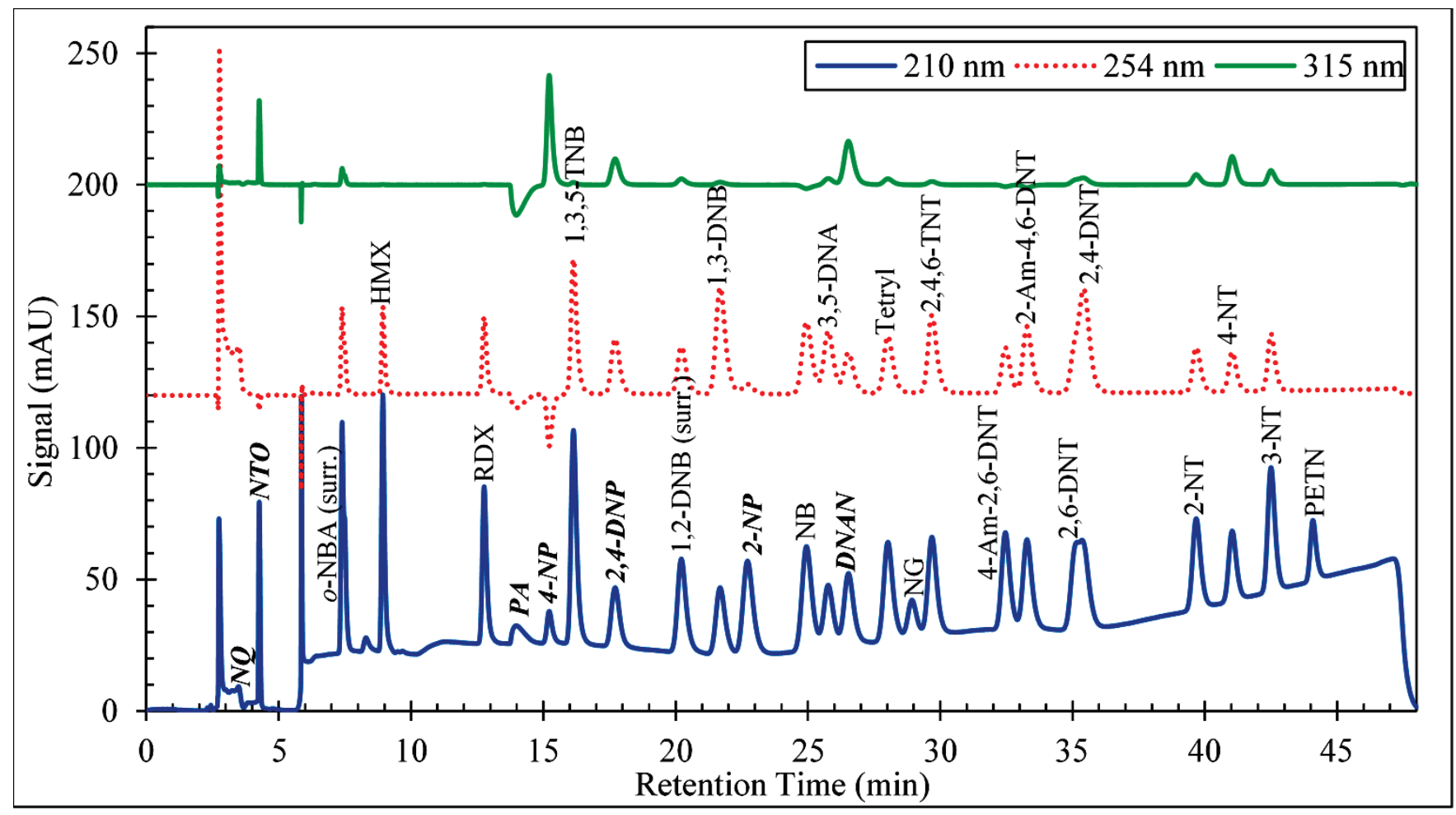

Bold, italicized are IM compounds and degradation products. 


\subsection{Secondary high-performance liquid chromatography-ultraviolet (HPLC-UV) method}

A secondary HPLC-UV method was developed for confirmatory analysis using Restek Pinnacle II Biphenyl, 5 Hm, $150 \times 4.6$ mm HPLC columns. Again, an optional Phenomenex SecurityGuard AQ C18 precolumn guard cartridge was included. The method parameters are shown in Table 2. As indicated, again either a $0.1 \%$ TFA or $0.25 \% \mathrm{FA}(\mathrm{v} / \mathrm{v})$ solution in water can be used to acidify the mobile phase for optimal chromatographic resolution. An example chromatogram is shown in Figure 2 (acquired using FA; retention times listed in Table 3). All chromatographic peaks were identified using individual reference standards.

Table 2. Secondary HPLC-UV separation solvent gradient scheme and other method conditions. (*or $0.25 \% \mathrm{FA} /$ water)

\begin{tabular}{|c|c|c|c|c|}
\hline \multicolumn{5}{|c|}{ Total run time: 35.0 min; Detection wavelengths: 210, 254, 315 nm } \\
Column temperature: $25^{\circ}$ C; Flow rate: 0.9 mL/min; Injection volume: $50 \mu \mathrm{L}$ \\
\hline Time (min) & Reagent water (\%) & MeOH (\%) & 0.1\% TFA/water (\%)* & ACN (\%) \\
\hline 0.00 & 75 & 10 & 10 & 5 \\
\hline 2.50 & 75 & 10 & 10 & 5 \\
\hline 2.60 & 39 & 46 & 10 & 5 \\
\hline 9.00 & 39 & 46 & 10 & 5 \\
\hline 9.10 & 33.5 & 51.5 & 10 & 5 \\
\hline 15.0 & 44 & 41 & 10 & 5 \\
\hline 29.0 & 25 & 60 & 10 & 5 \\
\hline 29.1 & 75 & 10 & 10 & 5 \\
\hline 35.0 & 75 & 10 & 10 & 5 \\
\hline
\end{tabular}


Figure 2. HPLC chromatograms of a mixed standard containing $10 \mathrm{mg} / \mathrm{L}$ of 24 legacy and IM compounds and 2 surrogates analyzed by the developed secondary HPLC-UV method ( $210 \mathrm{~nm}$ : bottom line; $254 \mathrm{~nm}$ : middle line; $315 \mathrm{~nm}$ : top line). (Retention times are listed in Table 3.)

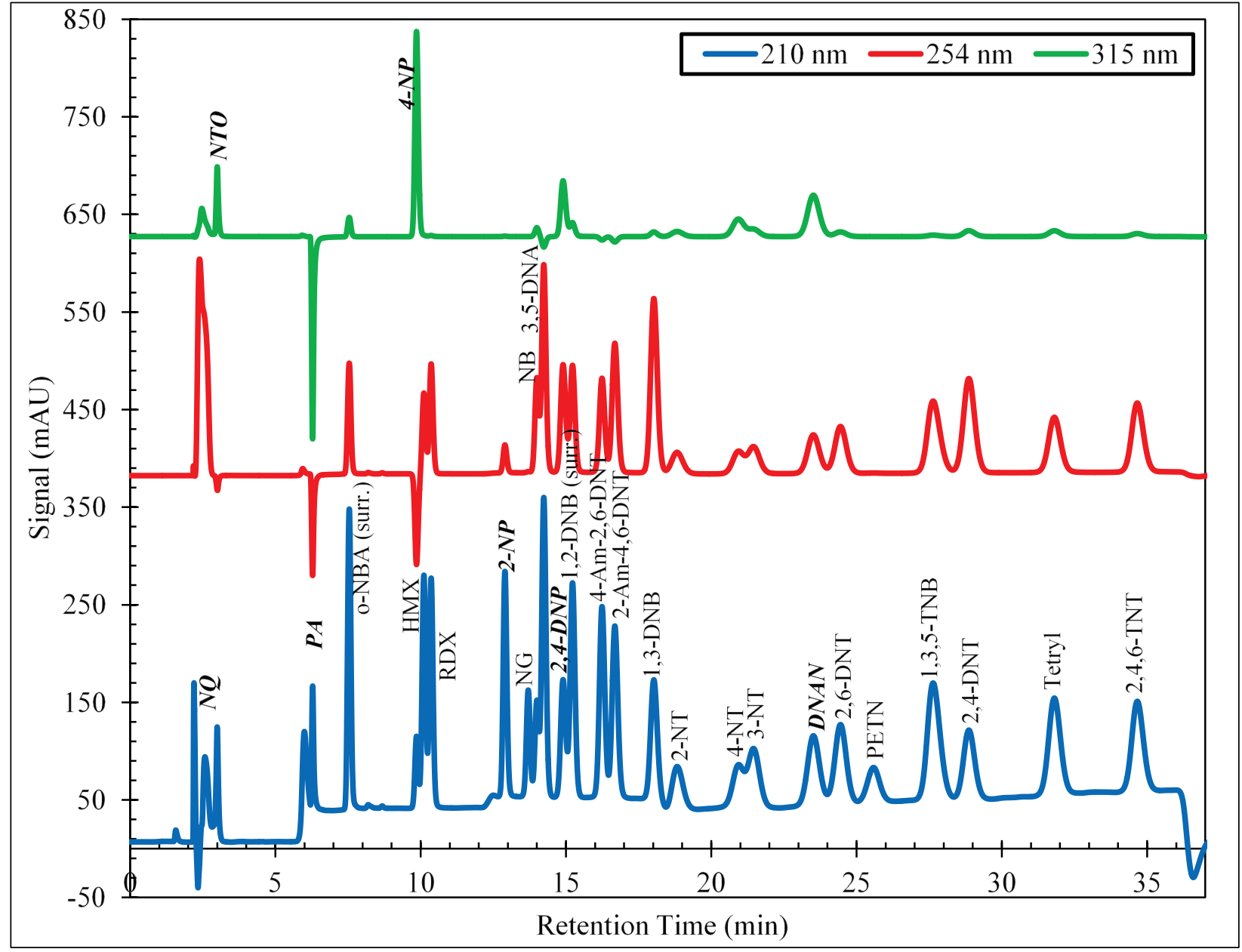

Bold, italicized are IM compounds and degradation products.

Table 3. Retention times ( $\mathrm{min}$ ) for the 24 compounds of interest and 2 surrogates, analyzed by the secondary HPLC-UV method.

\begin{tabular}{|c|c|c|}
\hline Peak \# & Compound & Retention time (min) \\
\hline 1 & NQ & 2.33 \\
\hline 2 & NTO (210nm) & 2.67 \\
\hline 2 & NTO (315nm) & 2.67 \\
\hline 3 & $P A(210 n m)$ & 5.86 \\
\hline 4 & $P A(315 n m)$ & 5.86 \\
\hline 5 & o-NBA (surrogate) & 6.87 \\
\hline 6 & HMX & 8.82 \\
\hline 6 & $4-N P$ & 8.98 \\
\hline 7 & RDX & 9.22 \\
\hline
\end{tabular}




\begin{tabular}{|c|c|c|}
\hline Peak \# & Compound & Retention time (min) \\
\hline 8 & $2-N P$ & 11.54 \\
\hline 9 & NG & 12.94 \\
\hline 10 & NB & 12.68 \\
\hline 11 & $3,5-D N A(210 n m)$ & 12.90 \\
\hline 12 & $3,5-D N A(254 n m)$ & 12.90 \\
\hline 13 & $2,4-D N P$ & 13.55 \\
\hline 14 & $1,2-D N B($ surrogate) & 13.89 \\
\hline 14 & $4-A m-2,6-D N T$ & 15.08 \\
\hline 15 & $2-$ Am-4,6-DNT & 15.62 \\
\hline 16 & $1,3-D N B$ & 17.13 \\
\hline 17 & $2-N T$ & 18.56 \\
\hline 18 & $4-N T$ & 20.47 \\
\hline 19 & $3-N T$ & 20.92 \\
\hline 20 & DNAN & 22.53 \\
\hline 21 & $2,6-D N T$ & 23.37 \\
\hline 22 & PETN & 24.51 \\
\hline 23 & $1,3,5-T N B$ & 25.62 \\
\hline 24 & $2,4-D N T$ & 26.63 \\
\hline 25 & Tetryl & 28.67 \\
\hline 26 & $2,4,6-T N T$ & 30.59 \\
\hline
\end{tabular}

\subsection{High-performance liquid chromatography-mass spectrometric (HPLC-MS) method}

An HPLC-MS scan mode method was developed using an Agilent 6120B single quadropole (SQ) system equipped with an atmospheric-pressure chemical ionization (APCI) source for confirmatory analysis of the 24 compounds of interest and 2 surrogates. Spray-chamber and MS-detector parameters for the scan mode method are provided in Table 4.

Chromatographic separation was achieved via the primary HPLC-UV method described in section 2.1. An example MS total ion chromatogram (TIC) is shown in Figure 3. Several ion masses were observed for each of the 26 compounds analyzed (shown in Table 5), with the exception of nitroglycerine (NG) and 2-, 3-, or 4-nitrotoluene (2-NT, 3-NT, 4-NT), which did not produce any detectable MS signal under the developed spray chamber and detector conditions. In addition, 1,3-dinitrobenzene (1,3-DNB) yielded only a single observed ion. Ions were identified where possible. Observed ions are listed in order of abundance for each compound. 
Table 4. Spray chamber and detector parameters for the developed HPLC-MS scan mode method.

\begin{tabular}{|l|l|}
\hline \multicolumn{1}{|c|}{ Parameter } & \multicolumn{1}{c|}{ Value } \\
\hline Source & $\mathrm{APCl}$ \\
\hline Ionization mode & Negative \\
\hline Drying gas $\left({ }^{\circ} \mathrm{C}\right)$ & 350 \\
\hline Vaporizer $\left({ }^{\circ} \mathrm{C}\right)$ & 325 \\
\hline Drying gas $(\mathrm{L} / \mathrm{min})$ & 4.0 \\
\hline Nebulizer $(\mathrm{psig})$ & 40 \\
\hline Corona $(\mu \mathrm{A})$ & 10 \\
\hline Capillary $(\mathrm{V})$ & 1,500 \\
\hline Mass range & $40-400$ \\
\hline Fragmentor & 100 \\
\hline Gain & 1.00 \\
\hline Threshold & 0 \\
\hline Step size & 0.20 \\
\hline Speed $(\mu / \mathrm{s})$ & 743 \\
\hline Peak width $(\mathrm{min})$ & 0.060 \\
\hline Cycle time $(\mathrm{s} / \mathrm{cycle})$ & 0.57 \\
\hline & \\
\hline
\end{tabular}


Figure 3. Total ion chromatogram (TIC) for a mixed standard containing $10 \mathrm{mg} / \mathrm{L}$ of 24 legacy and IM compounds and 2 surrogates analyzed by the developed confirmatory HPLC-MS scan mode method. (Retention times are listed in Table 5.)

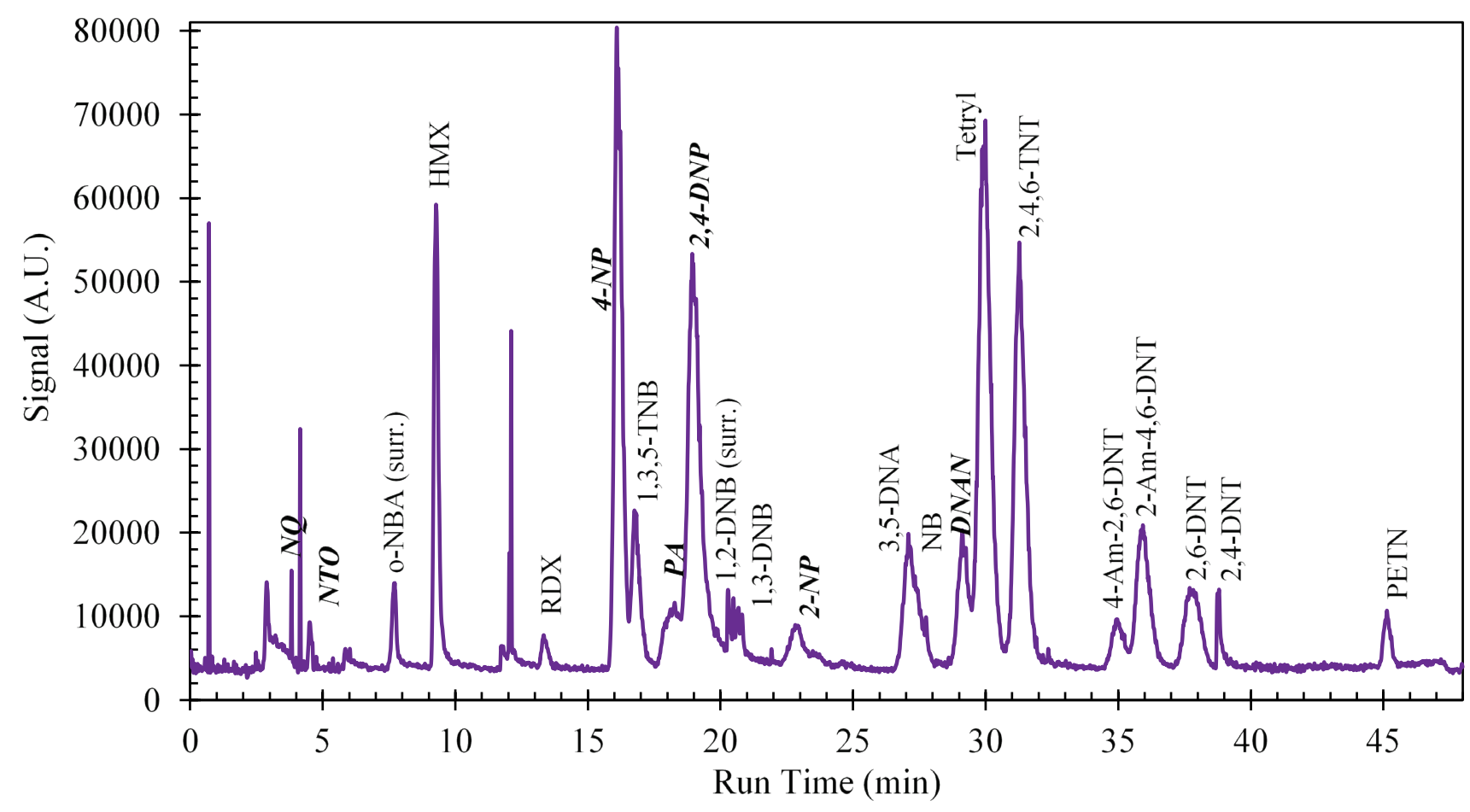

Bold, italicized are IM compounds and degradation products.

Table 5. Retention times ( $\mathrm{min}$ ), ion masses $(\mathrm{m} / \mathrm{z})$, and identities obtained for mixed standard containing 24 legacy and IM compounds and 2 surrogates using the developed HPLC-MS scan mode method.

\begin{tabular}{|c|c|c|c|}
\hline Retention time ( $\mathrm{min})$ & Compound & Ion mass $(\mathrm{m} / \mathrm{z})$ & Ion identity \\
\hline \multirow{2}{*}{3.78} & \multirow{2}{*}{$N Q$} & 203.6 & \\
\hline & & 103.0 & {$[M]-H$} \\
\hline \multirow{2}{*}{4.50} & \multirow{2}{*}{ NTO } & 129.0 & {$[M]-H$} \\
\hline & & 55.0 & \\
\hline \multirow{2}{*}{7.64} & \multirow{2}{*}{ o-NBA (surrogate) } & 122.0 & \\
\hline & & 167.0 & {$[\mathrm{M}]-\mathrm{H}$} \\
\hline \multirow{2}{*}{9.21} & \multirow{2}{*}{ HMX } & 341.0 & {$[\mathrm{M}]-\mathrm{H}+\mathrm{FA}$} \\
\hline & & 147.0 & {$[\mathrm{M}] / 2-\mathrm{H}$} \\
\hline \multirow{2}{*}{13.40} & \multirow{2}{*}{ RDX } & 267.0 & {$[\mathrm{M}]-\mathrm{H}+\mathrm{FA}$} \\
\hline & & 335.0 & {$[\mathrm{M}]-\mathrm{H}+\mathrm{TFA}$} \\
\hline \multirow{2}{*}{16.00} & \multirow{2}{*}{ 4-NP } & 108.0 & \\
\hline & & 138.0 & {$[M]-H$} \\
\hline
\end{tabular}




\begin{tabular}{|c|c|c|c|}
\hline Retention time (min) & Compound & Ion mass (m/z) & Ion identity \\
\hline \multirow{2}{*}{16.80} & \multirow{2}{*}{ 1,3,5-TNB } & 213.0 & {$[\mathrm{M}]-\mathrm{H}$} \\
\hline & & 183.0 & \\
\hline \multirow{2}{*}{18.20} & \multirow{2}{*}{$P A$} & 228.0 & {$[M]-H$} \\
\hline & & 211.9 & \\
\hline \multirow{2}{*}{18.80} & \multirow{2}{*}{ 2,4-DNP } & 183.0 & {$[M]-H$} \\
\hline & & 153.0 & \\
\hline \multirow{2}{*}{22.70} & \multirow{2}{*}{ 1,2-DNB (surrogate) } & 138.0 & \\
\hline & & 168.0 & {$[\mathrm{M}]-\mathrm{H}$} \\
\hline 23.55 & 1.3-DNB & 168.0 & {$[\mathrm{M}]-\mathrm{H}$} \\
\hline \multirow{2}{*}{24.60} & \multirow{2}{*}{$2-N P$} & 138.0 & {$[M]-H$} \\
\hline & & 122.0 & {$[\mathrm{M}]-\mathrm{H}_{2} \mathrm{O}-\mathrm{H}$} \\
\hline \multirow{2}{*}{27.10} & \multirow{2}{*}{ 3,5-DNA } & 182.0 & {$[\mathrm{M}]-\mathrm{H}$} \\
\hline & & 138.0 & \\
\hline \multirow{2}{*}{27.80} & \multirow{2}{*}{ NB } & 182.0 & {$[\mathrm{M}]-\mathrm{H}+\mathrm{HOAC}$} \\
\hline & & 153.0 & \\
\hline \multirow{2}{*}{29.00} & \multirow{2}{*}{$D N A N$} & 183.0 & {$[\mathrm{M}]-\mathrm{CH}_{3}$} \\
\hline & & 152.9 & \\
\hline \multirow{3}{*}{30.00} & \multirow{2}{*}{ Tetryl } & 241.0 & {$[\mathrm{M}]-\mathrm{H}+\mathrm{NO}_{2}{ }^{-*}$} \\
\hline & & 288.0 & {$[\mathrm{M}]-\mathrm{H}$} \\
\hline & $N G$ & 226.1 & [M]-H (not obsv.) \\
\hline \multirow{2}{*}{31.30} & \multirow{2}{*}{ 2,4,6-TNT } & 226.0 & {$[\mathrm{M}]-\mathrm{H}$} \\
\hline & & 210.0 & {$[\mathrm{M}]-\mathrm{H}_{2} \mathrm{O}-\mathrm{H}$} \\
\hline \multirow{2}{*}{35.10} & \multirow{2}{*}{ 4-Am-2,6-DNT } & 196.9 & {$[\mathrm{M}]-\mathrm{H}$} \\
\hline & & 167.0 & \\
\hline \multirow{2}{*}{35.95} & \multirow{2}{*}{ 2-Am-4,6-DNT } & 196.0 & {$[\mathrm{M}]-\mathrm{H}$} \\
\hline & & 179.9 & {$[\mathrm{M}]-\mathrm{H}_{2} \mathrm{O}-\mathrm{H}$} \\
\hline \multirow{2}{*}{37.54} & \multirow{2}{*}{ 2,6-DNT } & 152.0 & {$[\mathrm{M}]-30 *$} \\
\hline & & 122.1 & \\
\hline \multirow{2}{*}{37.87} & \multirow{2}{*}{ 2,4-DNT } & 165.0 & {$[\mathrm{M}]-\mathrm{H}_{2} \mathrm{O}-\mathrm{H}$} \\
\hline & & 181.0 & {$[\mathrm{M}]-\mathrm{H}$} \\
\hline $42.00-44.50$ & 2-NT/3-NT/4-NT & 136.1 & [M]-H (not obsv.) \\
\hline \multirow{2}{*}{45.10} & \multirow{2}{*}{ PETN } & 62.0 & $\mathrm{NO}_{3}-*$ \\
\hline & & 270.9 & \\
\hline
\end{tabular}

Bold, italicized are IM compounds and degradation products.

*Avci, Anilanmert, and Cengiz 2017; Gapeev, Signman, and Yinon 2003; Jiang 2010; Kinghorn, Milner, and Zweigenbaum 2005; Thurman and Ferrar 2012; and Xu et al. 2004. 


\subsection{Method for preparation of waters for direct-injection analysis}

Water samples known or suspected to contain the compounds of interest at levels detectable without extraction and preconcentration can be analyzed by direct injection using the developed analytical HPLC-UV or MS methods. In order to ensure the accurate analysis of ionic species (including NTO), an acidification step was added for direct-injection water samples. A solution of $1 \% \mathrm{HCl} / \mathrm{MeOH}$ was used to acidify and dilute water samples for final acid concentration of $0.5 \%(\mathrm{v} / \mathrm{v})$ and final solvent ratio of 50/50 MeOH/water.

\subsection{Solid-phase extraction (SPE) method for waters}

The SPE method developed under SERDP ER-2722 involved the sequential stacking of three different commercially-available SPE cartridges: (1) Strata X (polymeric reverse phase, $500 \mathrm{mg} / 6 \mathrm{~mL}$, Phenomenex); (2) Strata X-A (polymeric strong anion exchange, 500 $\mathrm{mg} / 6 \mathrm{~mL}$, Phenomenex); and (3) Supelclean ENVI-Carb (granular activated carbon, GAC, $500 \mathrm{mg} / 6 \mathrm{~mL}$, Supelco). The SPE cartridge conditioning, loading, and elution procedures were developed using common SPE methods for environmental water extraction and preconcentration. Specifically, SPE cartridges were conditioned with two 5 $\mathrm{mL}$ aliquots of $\mathrm{MeOH}$ and then equilibrated with two $5 \mathrm{~mL}$ aliquots of reagent water. Approximately $2 \mathrm{~mL}$ of reagent water was then added to each conditioned cartridge (to prevent drying) before the cartridges were stacked in the following order for loading using SPE tube adapters (Supelco): (1) Strata X at the top, (2) Strata X-A in the middle, and (3) ENVI-Carb on the bottom. Each triple-stacked SPE unit was loaded with $100 \mathrm{~mL}$ laboratory-spiked water sample containing all 26 compounds of interest (including two surrogates) or blank (unspiked) water sample. In order to allow for mass-balance analysis, a small amount of pass-through water was collected (for example, breakthrough determinations).

After allowing loaded SPE cartridges to air-dry under vacuum for approximately $10 \mathrm{~min}$ to remove all remaining water, the stacking order of the cartridges was reversed so that ENVI-Carb was at the top, Strata X-A was in the middle, and Strata X was on the bottom. Each sample-loaded SPE unit was eluted first with $5 \mathrm{~mL} \mathrm{MeOH}$, followed by $5 \mathrm{~mL} 2 \%$ $\mathrm{HCl} / \mathrm{MeOH}$. Extracts were collected separately, stored at $\leq 4^{\circ} \mathrm{C}$, and later prepared for analysis. $\mathrm{MeOH}$ and acidified $\mathrm{MeOH}$ extracts were analyzed 
individually, or by combining known ratios of each, and diluting with reagent water, for a final solvent ratio of $50 / 50 \mathrm{MeOH} /$ water.

\subsection{Solvent extraction (SE) method for soils}

The SE method developed under SERDP ER-2722 for soils was a two-stage extraction procedure, modified from the current USEPA Method 8330B. Sample collection, storage, drying, and grinding procedures were not modified. Specifically, soils were ground to $<0.85 \mathrm{~mm}$ (US Standard sieve \#20) particle diameter using a ceramic mortar and pestle, dried at $25^{\circ} \mathrm{C}$ in a forced-air convection oven in the absence of light. Soil samples were spiked (varying concentrations) with a mixed reference standard containing all 26 compounds of interest (including two surrogates) in a mixture of $\mathrm{MeOH} / \mathrm{ACN}$ or with unspiked $\mathrm{MeOH} / \mathrm{ACN}$, and vortexed for 1 min to mix. Samples were allowed to dry again in the oven at $25^{\circ} \mathrm{C}$ and then mixed using a horizontal sample roller for up to $18 \mathrm{~h}$ at $4^{\circ} \mathrm{C}$ in the absence of light.

Samples were then extracted using a two-stage ultrasonication procedure. For each sample, $5 \mathrm{~mL}$ of $\mathrm{MeOH}$ per gram of soil was added, and soilsolvent mixtures were placed in a cooled (by constant water replacement) ultrasonic bath for $6 \mathrm{~h}$ in the absence of light. Soil-solvent mixtures were centrifuged, and the supernatant $(\mathrm{MeOH}$ extract) was collected by syringe filtering through a $0.45 \mu \mathrm{m}$ PTFE hydrophobic disk filter. Next, $5 \mathrm{~mL}$ of $5 \mathrm{O} / 5 \mathrm{O} \mathrm{MeOH} /$ water per gram of soil was added, and the soil-solvent mixtures were placed in the cooled ultrasonic bath for another $14 \mathrm{~h}$ in the absence of light. Again, soil-solvent mixtures were centrifuged, and the supernatant (MeOH-water extract) was collected by syringe filtering through a new $0.45 \mu \mathrm{m}$ PTFE hydrophobic disk filter. Extracts were collected separately, stored at $\leq 4^{\circ} \mathrm{C}$, and later prepared for analysis. Extracts were analyzed individually, or by combining known ratios of each, and diluting for a final solvent ratio of $50 / 50 \mathrm{MeOH} /$ water.

\subsection{SE method for tissues}

The SE method developed under SERDP ER-2722 for tissues was a single $18 \mathrm{~h}$ ultrasonic extraction procedure, modified from the current USEPA Method 8330B. Briefly, whole tissues were ground without lyophilization (wet) under liquid nitrogen, using either a mill or stainless steel mortar and pestle, to as fine a particle size or paste as possible. Aliquotted samples were spiked with a mixed reference standard containing all 26 
compounds of interest (including two surrogates) in a mixture of $\mathrm{MeOH} / \mathrm{ACN}$ or with unspiked $\mathrm{MeOH} / \mathrm{ACN}$, vortexed for $1 \mathrm{~min}$, and were homogenized well prior to extraction. No post-spike drying step was performed for tissue samples. Homogenized samples were extracted using a single $18 \mathrm{~h}$ ultrasonication with $\mathrm{MeOH}$. For each sample, $5 \mathrm{~mL}$ of $\mathrm{MeOH}$ per gram of wet sample was added, and samples were placed in a cooled (by constant water replacement) ultrasonic bath for $18 \mathrm{~h}$ in the absence of light. Tissue-solvent mixtures were centrifuged, and the supernatant (MeOH extract) was collected by syringe filtering through a $0.45 \mu \mathrm{m}$ PTFE hydrophobic disk filter. Extracts were stored at $\leq 4^{\circ} \mathrm{C}$ and later prepared for analysis. $\mathrm{MeOH}$ extracts were analyzed after diluting with water for a final solvent ratio of $50 / 50 \mathrm{MeOH} /$ water. (At cold temperatures, some tissue extracts were observed to develop a precipitate. These samples were filtered further using either $0.45 \mu \mathrm{m}$ PTFE hydrophobic or $0.20 \mu \mathrm{m}$ Anotop 10 inorganic membrane disk filters.)

\subsection{Chromatographic interference reduction method for tissue extracts}

The tissue interference reduction method developed under SERDP ER2722 was a modified chromatographic method (Larson et al. 1999). Other common organic laboratory procedures were tested, including storage at low temperature or acidification to induce complete precipitation, followed by filtration. However, these methods were not as effective as chromatographic methods. Initial tests were performed using either neutral alumina or florisil, and later tests included combinations of these, basic alumina, or silica. In later tests, $\mathrm{MeOH}$ extracts of unspiked tissues were spiked for a final concentration of $6 \mathrm{mg} / \mathrm{L}$ of the 24 compounds of interest and 2 surrogates. Small-scale chromatography columns were prepared using $53 / 4$ in $(14.6 \mathrm{~cm}$ ) borosilicate pipettes, loaded with a total of $0.2 \mathrm{~g}$ packing material. Five different column packing schemes were used: (1) $0.1 \mathrm{~g}$ neutral alumina layered on top of $0.1 \mathrm{~g}$ florisil, (2) $0.1 \mathrm{~g}$ florisil layered on top of $0.1 \mathrm{~g}$ neutral alumina, (3) 1:1 mixed neutral alumina and florisil, (4), basic alumina, and (5) silica gel. Chromatography columns were wetted with $\mathrm{MeOH}$ just before loading $1 \mathrm{~mL}$ tissue $\mathrm{MeOH}$ extract. After the $1 \mathrm{~mL} \mathrm{MeOH}$ extract had completely passed through the column, $1 \mathrm{ml}$ of $\mathrm{MeOH}$ was used to elute, followed by $1 \mathrm{~mL} 2 \%$ $\mathrm{HCl} / \mathrm{MeOH}$. The resulting $3 \mathrm{~mL}$ of column-treated $\mathrm{MeOH}$ extract was vortexed to mix. Treated extracts were again stored at $\leq 4^{\circ} \mathrm{C}$ and later prepared for analysis by diluting with water for a final solvent ratio of $5 \mathrm{O} / 5 \mathrm{O} \mathrm{MeOH} /$ water. Several of the treatment options were effective at 
reducing the analytical interferences observed for the tissues. However, the silica gel option proved most effective for the majority of compounds in the majority of tissue types.

\subsection{Stability study methods}

Photo and thermal stability was investigated for each of the 24 compounds of interest and 2 surrogates by testing the current pre- and postextraction hold times for water and soils, which are 7/14 days for extraction, respectively, and 40 days for analysis for munition compound determinations performed using USEPA Method 8330B. Extraction and analysis hold times were not previously reported for tissues in Method $8330 B$.

Reagent water was batch-spiked, aliquotted, extracted (using the developed SPE method), and analyzed (using the primary HPLC-UV method) on Day o. Portions of laboratory-spiked water were stored under three different conditions until Day 7. The three storage conditions were (1) cold $\left(4^{\circ} \mathrm{C}\right)$, dark (amber containers); (2) room temperature $\left(25^{\circ} \mathrm{C}\right)$, dark; and (3) room temperature, light (clear containers). On Day 7, the stored water samples were extracted and analyzed. In addition to storing portions of laboratory-spiked water on Day o, aliquots of Day o $\mathrm{MeOH} /$ acidified $\mathrm{MeOH}$ extracts were also stored under the same three conditions until Day 40. On Day 40, the stored $\mathrm{MeOH}$ and acidified $\mathrm{MeOH}$ extracts were analyzed using the primary HPLC-UV method. Included as part of the stability studies in water were direct-injection (no SPE) water samples, which were spiked at a higher level to enable detection without preconcentration.

Three soils were batch-spiked and extracted (using the methods described in section 2.6) and analyzed (using the primary HPLC-UV method) on Day $\mathrm{o} / 1$ (due to the two-day extraction procedure). Portions of the laboratoryspiked soils were stored under the same three conditions as for water samples until Day 14. On Day 14, the stored soil samples were extracted (Day 14/15) and analyzed (Day 15). Again, in addition to storing portions of laboratory-spiked soils on Day o, aliquots of Day o/1 MeOH and $\mathrm{MeOH} /$ water extracts (combined) were also stored under the same three conditions until Day 40. On Day 40, the stored extracts were analyzed using the primary HPLC-UV method. 


\subsection{Interlaboratory batch analysis methods}

An interlaboratory batch study was carried out at ERDC-EL and ERDCCRREL. Briefly, five water sources (reagent, tap, river, sea, and ground) and six soil sources (Aberdeen, Jefferson, Memphis, Riley, Yuma, and ASTM fat clay) were batch-spiked, homogenized, aliquotted, and distributed to each laboratory for extraction using the developed SPE and SE methods, followed by analysis using the developed primary HPLC-UV method. Samples were spiked with the 24 compounds of interest and 2 surrogates. High-level, direct-injection water samples were spiked at 2 $\mathrm{mg} / \mathrm{L}$, and low-level water samples for SPE extraction and preconcentration were spiked at $0.10 \mathrm{mg} / \mathrm{L}$. Soils were spiked at 20 $\mathrm{mg} / \mathrm{kg}$. Each laboratory received identical protocols for sample extraction, analytical sample preparation, and analysis.

During cross-laboratory studies using the direct injection method for waters, much lower recoveries for NTO, and in some cases $o$-NBA surrogate, were observed for field water samples than for reagent water. Therefore, further experiments were carried out in which the $\mathrm{pH}$ of samples to be analyzed by direct injection was adjusted using $2 \%$ $\mathrm{HCl} / \mathrm{MeOH}$ (the same used for stage two of SPE elution), so that the final acid concentration was the same as in SPE extracted and preconcentrated samples, or double. Briefly, reagent water, Vicksburg municipal water (tap), and three field water samples were spiked with the 24 compounds of interest and 2 surrogates for a final concentration of $1 \mathrm{mg} / \mathrm{L}$ and either $0.5 \%$ or $1.0 \% \mathrm{HCl}(\mathrm{v} / \mathrm{v})$. The acidified, laboratory-spiked water samples were diluted 1:1 with $\mathrm{MeOH}$ and analyzed using the developed primary HPLC-UV method. 


\section{Results and Discussion}

\subsection{Primary HPLC-UV method}

Previously developed (Russell et al. 2014) and currently employed munition compound analysis methods (USEPA 8330B, in-house IM method) were used as references in the development of the primary HPLC-UV method. Figure 4 shows the isocratic or gradient methods referenced. The separation solvent gradient scheme and other method conditions for the primary HPLC-UV method itself are shown in Table 1 in section 2.1. Peak identities (obtained by analysis of individual reference standards), method detection limits (MDLs), and linear dynamic ranges (LDRs) are provided in Table 6.

Figure 4. Previous HPLC methods used for munition compound determinations, including (a) current USEPA Method 8330B employed at the Engineer Research and Development Center-Environmental Laboratory (ERDC-EL) for HPLC-UV analysis of legacy compounds, (b) method developed at ERDC-EL for HPLC-MS analysis of insensitive munition (IM) compounds (Russell et al. 2014), (c) current method employed at ERDC-EL for HPLC-UV analysis of IM compounds, and (d) primary column HPLC-UV method developed for simultaneous analysis of legacy and IM compounds for SERDP ER-2722.

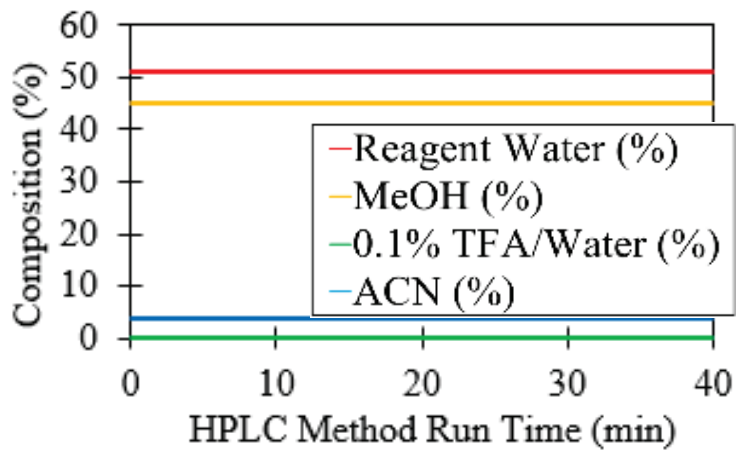

(a)

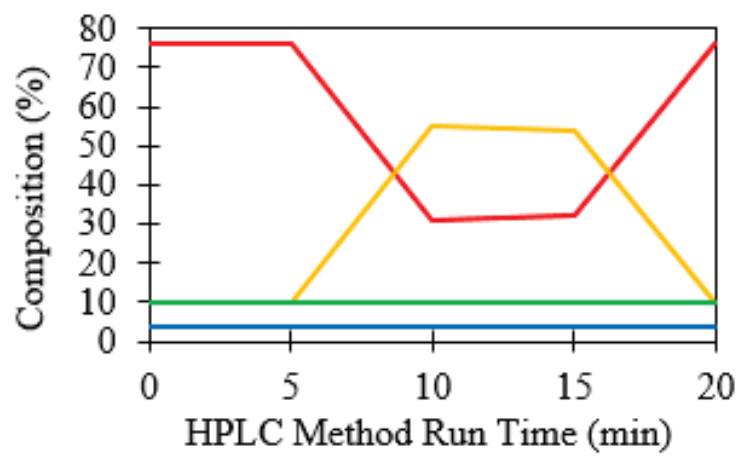

(c)

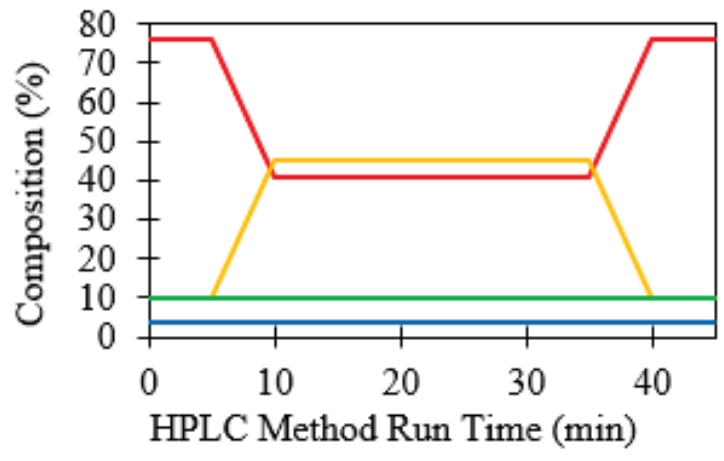

(b)

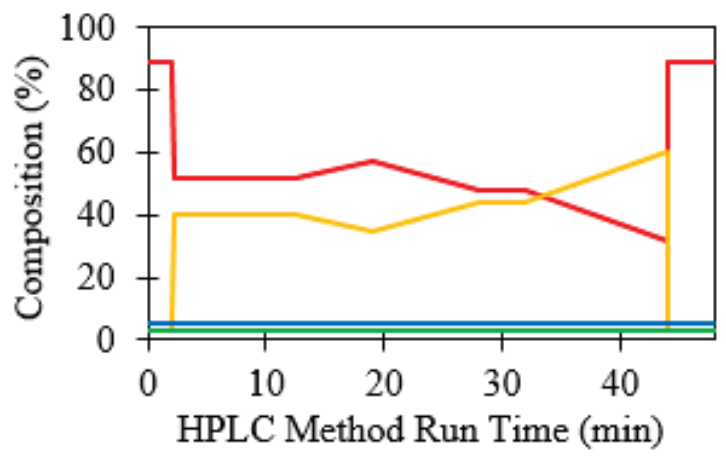

(d) 
Table 6. Retention times ( $\mathrm{min}$ ), method detection limits (MDLs) and linear dynamic range (LDR) upper limits (ULs) for the 24 compounds of interest and 2 surrogates, determined in direct-injection water (Est. MDL), reagent water that underwent SPE preconcentration, and Ottawa sand that underwent SE, analyzed by the primary HPLC-UV method.

\begin{tabular}{|c|c|c|c|c|c|c|}
\hline Peak \# & Compound & $\begin{array}{l}\text { Retention } \\
\text { time (min) }\end{array}$ & $\begin{array}{c}\text { Est. MDL } \\
(n=10 \text { at } 40 \\
\mu \mathrm{g} / \mathrm{L})(\mu \mathrm{g} / \mathrm{L})\end{array}$ & $\begin{array}{l}\text { MDL in reagent } \\
\text { water }(n=10 \text { at } \\
40 \mu \mathrm{g} / \mathrm{L})(\mu \mathrm{g} / \mathrm{L})\end{array}$ & $\begin{array}{c}\text { MDL in Ottawa } \\
\text { sand }(n=10 \text { at } 4 \\
\mathrm{mg} / \mathrm{kg})(\mathrm{mg} / \mathrm{kg})\end{array}$ & $\begin{array}{l}\text { LDR UL } \\
(\mathrm{mg} / \mathrm{L})\end{array}$ \\
\hline 1 & $N Q$ & 3.51 & 16 & 12 & 2.64 & $\geq 80$ \\
\hline 2 & NTO (210nm) & 4.29 & 6 & 20 & 1.26 & $\geq 50$ \\
\hline 2 & NTO $(315 n m)$ & 4.29 & 9 & 15 & 0.82 & $\geq 60$ \\
\hline 3 & o-NBA (surrogate) & 7.45 & 12 & 49 & 0.32 & $\geq 80$ \\
\hline 4 & HMX & 8.96 & 6 & 11 & 1.18 & $\geq 70$ \\
\hline 5 & RDX & 12.81 & 6 & 9 & 0.66 & $\geq 70^{a}$ \\
\hline 6 & PA (210nm) & 14.64 & 10 & 23 & 3.88 & $\geq 70^{a}$ \\
\hline 6 & $P A(315 n m)$ & 14.58 & 12 & 11 & 1.44 & $\geq 80^{\circ}$ \\
\hline 7 & 4-NP & 15.31 & 10 & 7 & 0.94 & $\geq 80$ \\
\hline 8 & 1,3,5-TNB & 16.17 & 11 & 13 & 1.14 & $\geq 80$ \\
\hline 9 & 2,4-DNP & 17.86 & 9 & 22 & 4.42 & $\geq 80$ \\
\hline 10 & 1,2-DNB (surrogate) & 20.35 & 15 & 16 & 2.38 & $\geq 70$ \\
\hline 11 & 1,3-DNB & 21.80 & 7 & 12 & 0.94 & $\geq 80$ \\
\hline 12 & 2-NP & 22.91 & 12 & 14 & 1.26 & $\geq 80$ \\
\hline 13 & NB & 25.42 & 9 & 10 & 1.74 & $\geq 80$ \\
\hline 14 & 3,5-DNA (210nm) & 26.16 & 13 & 16 & 3.02 & $\geq 70$ \\
\hline 14 & 3,5-DNA (254nm) & 25.93 & 13 & 13 & 0.38 & $\geq 70$ \\
\hline 15 & DNAN & 26.89 & 11 & 16 & 1.58 & $\geq 70$ \\
\hline 16 & Tetryl & 28.43 & 12 & 8 & 2.08 & $\geq 70$ \\
\hline 17 & $N G$ & 29.30 & 17 & 27 & 5.06 & $\geq 70$ \\
\hline 18 & 2,4,6-TNT & 30.06 & 15 & 11 & 2.14 & $\geq 70$ \\
\hline 19 & 4-Am-2,6-DNT & 32.60 & 11 & 17 & 2.56 & $\geq 80$ \\
\hline 20 & 2-Am-4,6-DNT & 33.43 & 11 & 22 & 2.50 & $\geq 80$ \\
\hline 21 & 2,6-DNT & 35.25 & 14 & 37 & 2.82 & $\geq 70$ \\
\hline 22 & 2,4-DNT & 35.57 & 7 & 12 & 0.70 & $\geq 80$ \\
\hline 23 & 2-NT & 40.18 & 13 & 14 & 1.08 & $\geq 80$ \\
\hline 24 & 4-NT & 41.42 & 12 & 16 & 2.00 & $\geq 80$ \\
\hline 25 & 3-NT & 42.84 & 14 & 21 & 0.84 & $\geq 80$ \\
\hline 26 & PETN & 44.38 & 16 & 22 & 3.46 & $\geq 80$ \\
\hline
\end{tabular}


In the table, LDR values represent the highest concentration of spiked standard analyzed within $\pm 10 \%$ of the known spike concentration, using a complete mixed reference standard of the 24 compounds of interest and 2 surrogates. Because most of the commercially available individual reference standards and mixes were acquired at $1,000 \mathrm{mg} / \mathrm{L}$ in $\mathrm{MeOH}$ or $\mathrm{ACN}$, solutions at higher concentrations $(>50 \mathrm{mg} / \mathrm{L}$ ) contained greater than 1:1 MeOH/water ratios, which was determined to be the optimal analytical sample solvent mixture (see Figure 9). Because previous studies indicated that $\mathrm{MeOH} /$ water ratios of 9:1 caused chromatographic deterioration (see Figure 9), $80 \mathrm{mg} / \mathrm{L}$ with 8:1 MeOH/water content was the highest concentration tested. The upper limit of the linear range for some compounds may be higher than $80 \mathrm{mg} / \mathrm{L}$. Results for multiple wavelengths were included for NTO, PA, and 3,5-DNA, to allow for quantitation using either wavelength. In some cases, detection of NTO and PA at $315 \mathrm{~nm}$ may be preferred in order to minimize the effects of analytical interferences-for example, with tissue samples. The PA chromatographic peak at $315 \mathrm{~nm}$ is inverted (versus at $210 \mathrm{~nm}$ ) and lies below the baseline. For 3,5-DNA, the detection limits obtained for $210 \mathrm{~nm}$ and $254 \mathrm{~nm}$ were typically very similar, and either wavelength could be used for quantitation. MDLs were determined for direct-injection water samples (Est. $M D L)$, SPE water samples (MDL in reagent water), and SE solid samples with Ottawa sand (MDL in Ottawa sand).

For simultaneous legacy and IM compound analysis, it was clear that a more complex gradient of the major aqueous (water) and organic phases $(\mathrm{MeOH})$ would be required, with the final method incorporating elements of all three of the methods referenced (Figure $4 a-c$ ). Specifically, the primary HPLC-UV method gradient started with very low percentage of $\mathrm{MeOH}$ that increased sharply after $2 \mathrm{~min}$, initiating a period of approximately $30 \mathrm{~min}$ during which the percentage of water was to varying degrees slightly greater than the percentage of $\mathrm{MeOH}$, followed by a period of approximately 10 min during which the percentage of $\mathrm{MeOH}$ surpassed the percentage of water and continued to increase up to $60 \%$. A brief re-equilibration period was placed at the end of the gradient method in order to allow the system time between sample injections to reequilibrate to initial conditions. The small decrease in $\mathrm{MeOH}$ from $40 \%$ at $12.5 \mathrm{~min}$ to $35 \%$ at $19 \mathrm{~min}$ (Figure $4 \mathrm{~d}$ ) was introduced in order to improve separation of the hydrophobic compounds that elute between 20-30 min, as neither isocratic conditions nor a linear increase in percentage of $\mathrm{MeOH}$ from 12.5 to $28 \mathrm{~min}$ resulted in well-resolved, stable chromatography. The 
developed primary HPLC-UV method incorporated conditions favorable for separation of the 24 chemically disparate compounds of interest (and 2 surrogates). Further details on the optimization of the initial percentage $\mathrm{MeOH}$, as well as the isocratic percentage of $0.1 \% \mathrm{TFA}$ (or $0.25 \% \mathrm{FA}$ ) and percentage of ACN throughout the method are discussed below.

Throughout primary column HPLC-UV method development, NQ and 2,6/2,4-DNT resolution remained the most challenging. Resolution of 2,6DNT and 2,4-DNT was observed to vary greatly across manufacturer production lots and individual parts; however, resolution tended to be improved for well-conditioned, newer columns. Therefore, a decrease in the resolution of these two compounds could signal that a column has degraded, and a new column could improve analyses. Meanwhile, NQ, as anticipated, seemed to suffer the most from solvent effects, specifically changes in $\mathrm{MeOH}$ concentration, resulting in peak splitting and migration, so that the optimal initial percentage of $\mathrm{MeOH}$ determined for the primary HPLC-UV separation served to minimize these negative effects but did not completely eliminate them. In fact, NQ resolution (retention time and peak shape) depended greatly on the aqueous-to-organic ratio in both sample solvent matrix and elution solvent gradient, with comprehensive studies discussed below. Therefore, secondary confirmation of NQ by the secondary HPLC-UV or -MS method may be necessary to confirm results obtained using the primary column.

As previously mentioned, solvent effects on the gradient method, as well as on sample preparation, were studied. Preliminary method development results indicated that a complex, multistage gradient would be required for separation of all compounds of interest and that the most effective initial percentage of $\mathrm{MeOH}$ concentration was likely to be $<10 \%$. It was, thus, necessary to determine the initial percentage of $\mathrm{MeOH}$ that would yield the most stable retention times and peak shapes for NQ and NTO, the most polar and earliest-eluting compounds of interest, to ensure reliable quantitation. The effect of varying the solvent gradient initial percentage $\mathrm{MeOH}$ from $2 \%$ to $15 \%$ was studied, while holding the isocratic $0.1 \%$ TFA and $\mathrm{ACN}$ constant at $3 \%$ and $5 \%$, respectively, using a $5 \mathrm{mg} / \mathrm{L}$ mixed standard containing all 24 compounds of interest and 1,2-DNB (surrogate) prepared in 50/50 MeOH/water. Little effect was observed for any compounds other than NQ and NTO (data not shown). Both NQ and NTO underwent large retention time shifts ( $>0.5 \mathrm{~min}$ ) and changes in peak shape, including reduced intensity and splitting of NTO at $>10 \% \mathrm{MeOH}$ 
(Figure 5). Meanwhile, NQ shifted almost entirely into the void peak but did become sharper as the $\mathrm{MeOH}$ concentration increased. Overall, it was determined that $3 \% \mathrm{MeOH}$ yielded the best NTO peak shape and intensity, as well as NQ distance from both the void peak and NTO, with sufficient baseline resolution for reliable quantitation.

The effect of varying the isocratic mobile phase component $0.1 \%$ TFA/water from $2 \%$ to $15 \%$ was studied, while holding the initial $\mathrm{MeOH}$ and isocratic ACN constant at $3 \%$ and $5 \%$, respectively, using a $5 \mathrm{mg} / \mathrm{L}$ mixed standard containing all 24 compounds of interest and 1,2-DNB (surrogate) prepared in 50/50 MeOH/water. Little effect was observed for compounds with retention times greater than 20 min (data not shown), which were generally nonionic. NQ was for the most part unaffected by changes in \% TFA (Figure 6a). The most significant effects were observed for PA, NTO, and 2,4-DNP, which were the most acidic compounds studied ( $\mathrm{pKa}=0.38,3.76$, and 4.11, respectively). Meanwhile, NTO underwent a great deal of peak broadening (from a peak width of 0.1 min to $0.3 \mathrm{~min}$ ) and retention time shift of approximately $0.5 \mathrm{~min}$ (Figure 6a) as $0.1 \% \mathrm{TFA} /$ water increased from $2 \%$ to $15 \%$. 
Figure 5. Effect of varying the solvent gradient initial $\mathrm{MeOH}$ from $2 \%$ to $15 \%$, while holding the $0.1 \%$ TFA/water and ACN constant, using $5 \mathrm{mg} / \mathrm{L}$ mixed standard containing all 24 compounds of interest and 1,2-DNB surrogate prepared in 50/50 $\mathrm{MeOH} /$ water. (Detection at $210 \mathrm{~nm}$ )

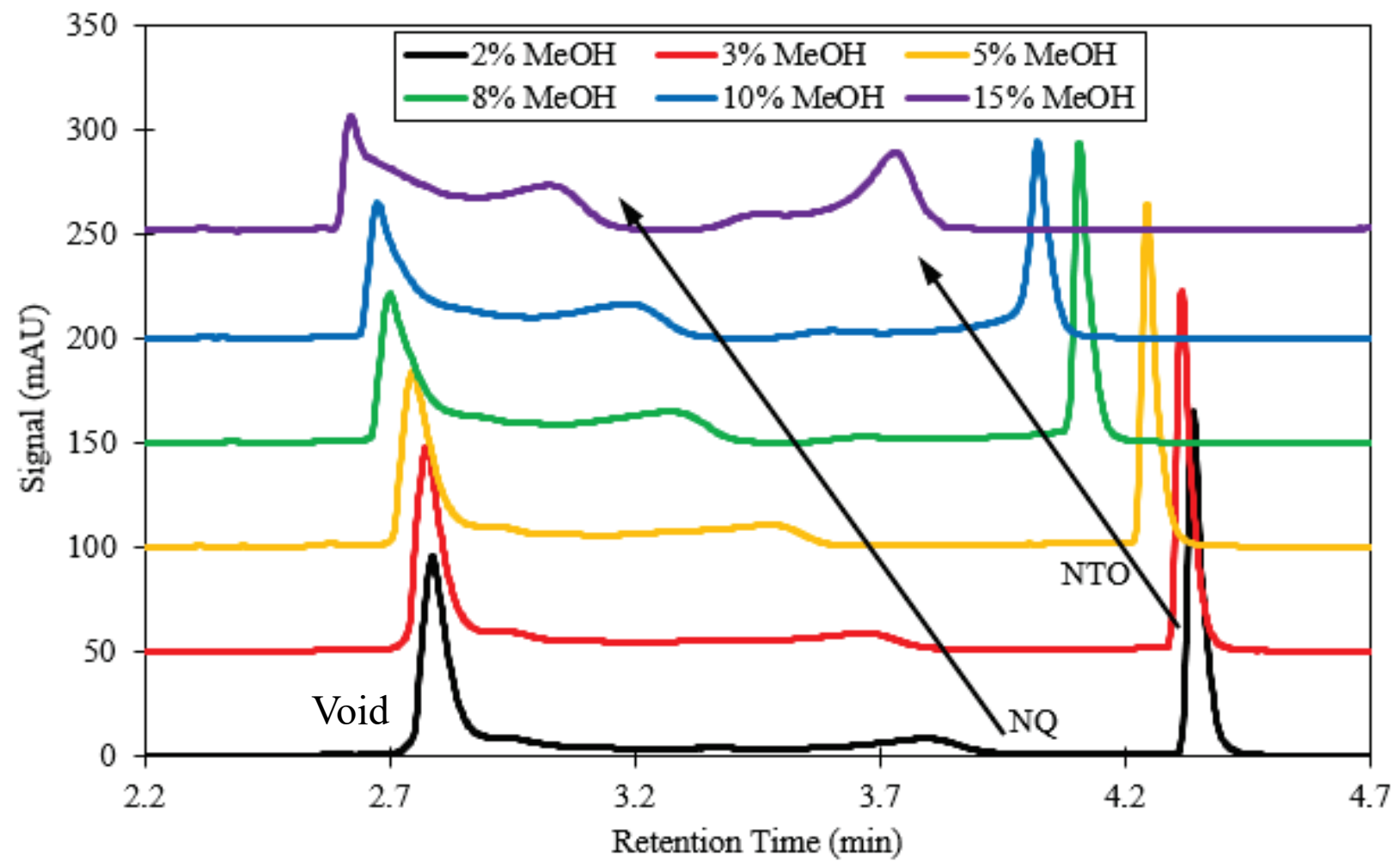

In addition, both PA and 2,4-DNP underwent extreme peak shifting (ranging 12-15 min and 16.5-18 min, respectively), and shifted inversely with respect to one another, on the basis of the TFA concentration. At lower $\mathrm{pH}$, PA shifted to earlier retention times, while 2,4-DNP shifted to later retention times. No analytical (coelution) challenges arose because of 2,4-DNP peak shifting.

Conversely, PA coeluted with 4-NP at $2 \% 0.1 \% \mathrm{TFA} /$ water, shifted left to coelute with RDX with the $0.1 \% \mathrm{TFA} /$ water set to $8 \%$ of the mobile phase composition, and eluted before RDX by $15 \%$ 0.1\% TFA/water. In another part of these studies (data not shown), PA was also observed to undergo retention time shifts over a range of approximately 1 min as a result of increased or decreased sample $\mathrm{pH}$ arising from changes in the concentration of PA itself. Higher concentrations of PA resulted in earlier elution ( $\sim 13 \mathrm{~min}$ ), and lower concentrations of PA resulted in later elution ( $\sim 14 \mathrm{~min}$ ), similar to the TFA-dependent shifting observed in Figure $6 \mathrm{~b}$. This wide variability of PA retention time was due to its very low pKa, which 
was not buffered well by the TFA in the mobile phase. Over the course of the current effort, PA concentration-dependent PA peak shifting was observed over a range of concentrations because of $\mathrm{pH}$ variability in the sample matrix or in the prepared 0.1\% TFA/water mobile phase, or both. Considering all effects of TFA concentration on the primary HPLC-UV method chromatography, a $3 \%$ isocratic mobile phase composition of $0.1 \%$ $\mathrm{TFA} /$ water was chosen, to enable efficient and consistent quantitation of NTO and PA. As a technical note, the extreme $\mathrm{pH}$ sensitivity observed for PA highlighted the importance of careful preparation of the 0.1\% TFA/water solvent to ensure chromatographic stability.

The effect of varying the solvent gradient isocratic percentage of ACN from $5 \%$ to $8 \%$ was studied, while holding the initial $\mathrm{MeOH}$ and isocratic $0.1 \%$ $\mathrm{TFA} /$ water constant at $3 \%$, using a $5 \mathrm{mg} / \mathrm{L}$ mixed standard containing all 24 compounds of interest and 1,2-DNB (surrogate) prepared in 50/50 $\mathrm{MeOH} /$ water (Figure 7). While retention time shifts for NQ and NTO from $3.6 \mathrm{~min}$ to $3.5 \mathrm{~min}$ and $4.3 \mathrm{~min}$ to $3.9 \mathrm{~min}$, respectively, as percentage of $\mathrm{ACN}$ increased from $5 \%$ to $8 \%$, peak shape, resolution, and intensity were not affected by changes in percentage of ACN (Figure 7a). However, ACN concentration was shown to impact the resolution of middle- and lateeluting compounds, including most of the legacy munition compounds (present in the current USEPA Method 8330B), resulting in an overall decrease of $2-3$ min method run time, and one or more coelutions at $>6 \%$ $\mathrm{ACN}$ (Figure 7b). Because there were no coelutions at either $5 \%$ or $6 \%$ $\mathrm{ACN}$, and because some compounds were better resolved either at $5 \%\left(1,3^{-}\right.$ $\mathrm{DNB} / 2-\mathrm{NP}$ ) or at $6 \% \mathrm{ACN}$ (Tetryl/NG), the use of either $5 \%$ or $6 \%$ isocratic $\mathrm{ACN}$ would be appropriate.

Cursory experiments were carried out to investigate whether the gradient method could be shortened by ramping up the percentage of ACN during the final 20 min of the method (Figure 8). For this test, $6 \% \mathrm{ACN}$ was used from $0-28$ min then was increased from $6 \%$ to $20 \%$ from $28-44 \mathrm{~min}$. Total run time was shortened by $5 \mathrm{~min}$; however, the introduction of an ACN gradient would only be recommended in cases where the additional complication to the method resulted in significant benefit to the user.

Further experiments showed that NQ underwent substantial changes in retention time (from $3.3 \mathrm{~min}$ to $3.9 \mathrm{~min}$ ) and peak shape, including splitting and broadening, resulting in several small peaks that appeared near (and possibly included within) the void peak (2.7 $\mathrm{min})$ and one main 
peak that shifted closer to the NTO peak as percentage of $\mathrm{MeOH}$ composition increased (Figure 9a). Overall, a 50/50 MeOH/water sample solvent composition was determined to be optimal. Neither the NTO nor any of the later-eluting analytes were negatively affected by a $50 \% \mathrm{MeOH}$ composition, and adequate baseline resolution enabled analysis using the main NQ peak (3.65 min), which yielded a linear calibration curve from $0.020 \mathrm{mg} / \mathrm{L}$ to $20 \mathrm{mg} / \mathrm{L}\left(\mathrm{R}^{2} \geq 0.97\right.$ ) with MDL of $16 \mu \mathrm{g} / \mathrm{L}$ (Table 6). For the majority of included compounds, no peak broadening or shifting was observed up to $75 \% \mathrm{MeOH}$, with the first signs of negative chromatographic effects appearing at $90 \% \mathrm{MeOH}$ between 8 and $28 \mathrm{~min}$ (Figure 9b). Overall, NQ posed the greatest analytical challenges, because of its highly polar character. The solvent gradient and sample solvent composition conditions developed for the primary HPLC-UV method served to minimize negative effects on NQ retention time and peak shape but did not eliminate them, so that a confirmation method (such as the secondary HPLC-UV or -MS method described) should be used to confirm NQ determinations. 
Figure 6. Effect of varying the solvent gradient isocratic $0.1 \%$ TFA/water from $2 \%$ to $15 \%$, while setting the initial $\mathrm{MeOH}$ at $3 \%$ and holding ACN constant at $5 \%$, using 5 $\mathrm{mg} / \mathrm{L}$ mixed standards containing all 24 compounds of interest and 1,2-DNB surrogate prepared in 50/50 MeOH/water. (a) Effect on NQ and NTO, (b) Effect on PA and 2,4-DNP retention times $(\mathrm{min})$ and peak shapes.

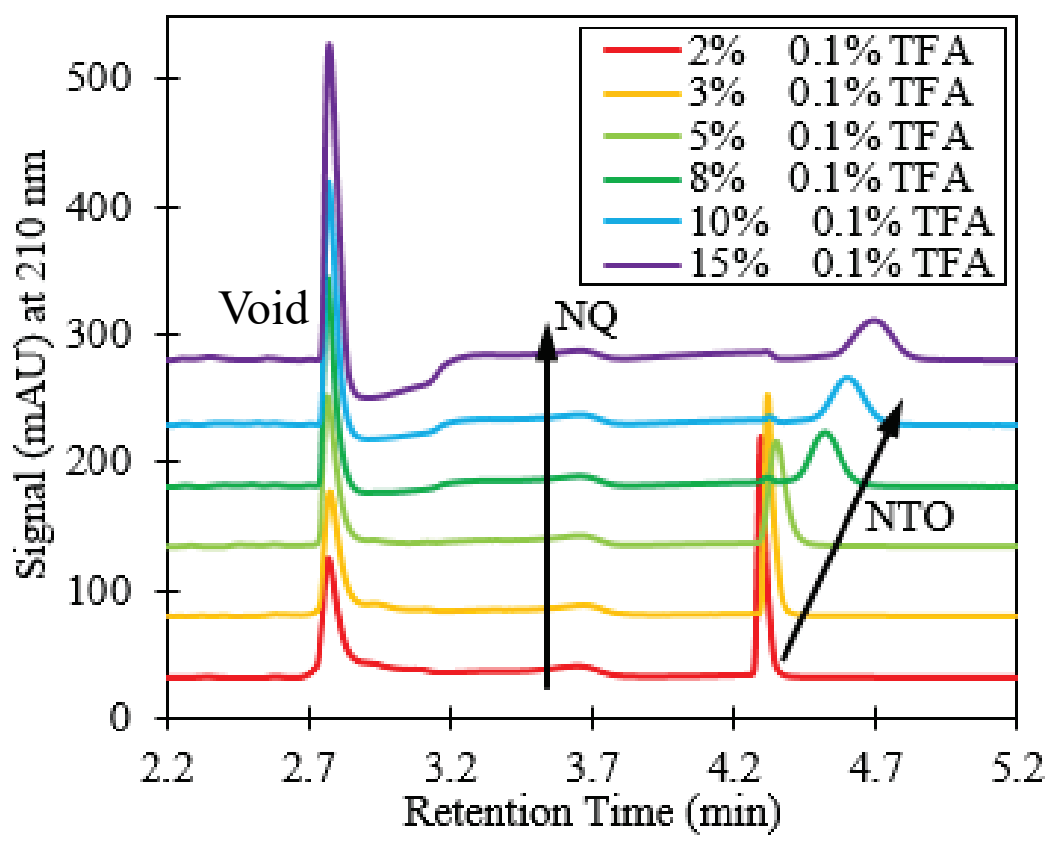

(a)

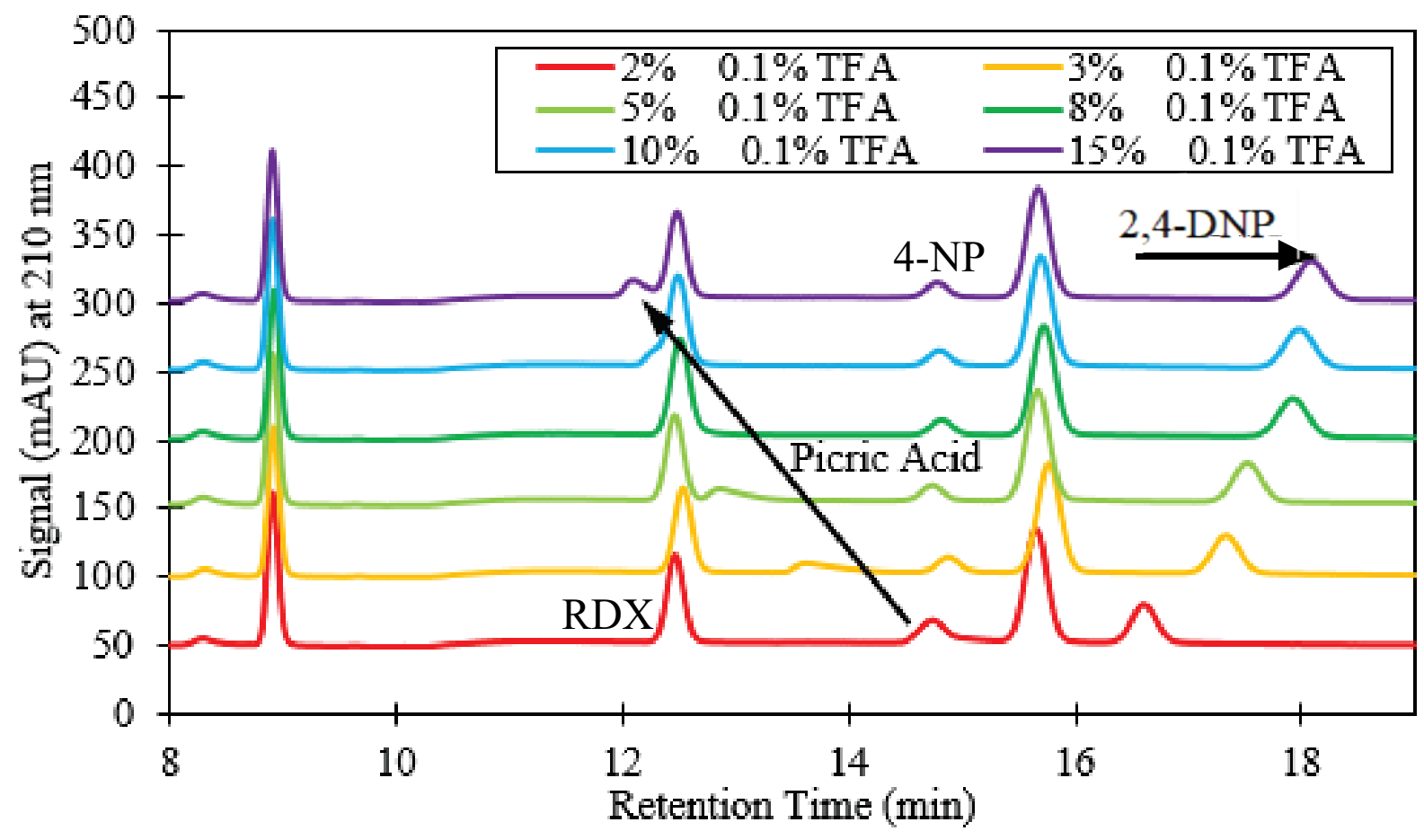

(b) 
Figure 7. Effect of varying the solvent gradient isocratic $\%$ ACN from $5 \%$ to $8 \%$, while setting the initial $\% \mathrm{MeOH}$ at $3 \%$ and holding $\% 0.1 \%$ TFA/water constant at 3\%, using

$5 \mathrm{mg} / \mathrm{L}$ mixed standards containing all 24 compounds of interest and 1,2-DNB surrogate prepared in 50/50 MeOH/water. (a) Effect on NQ and NTO, (b) Effect on middle- and late-eluting compounds.

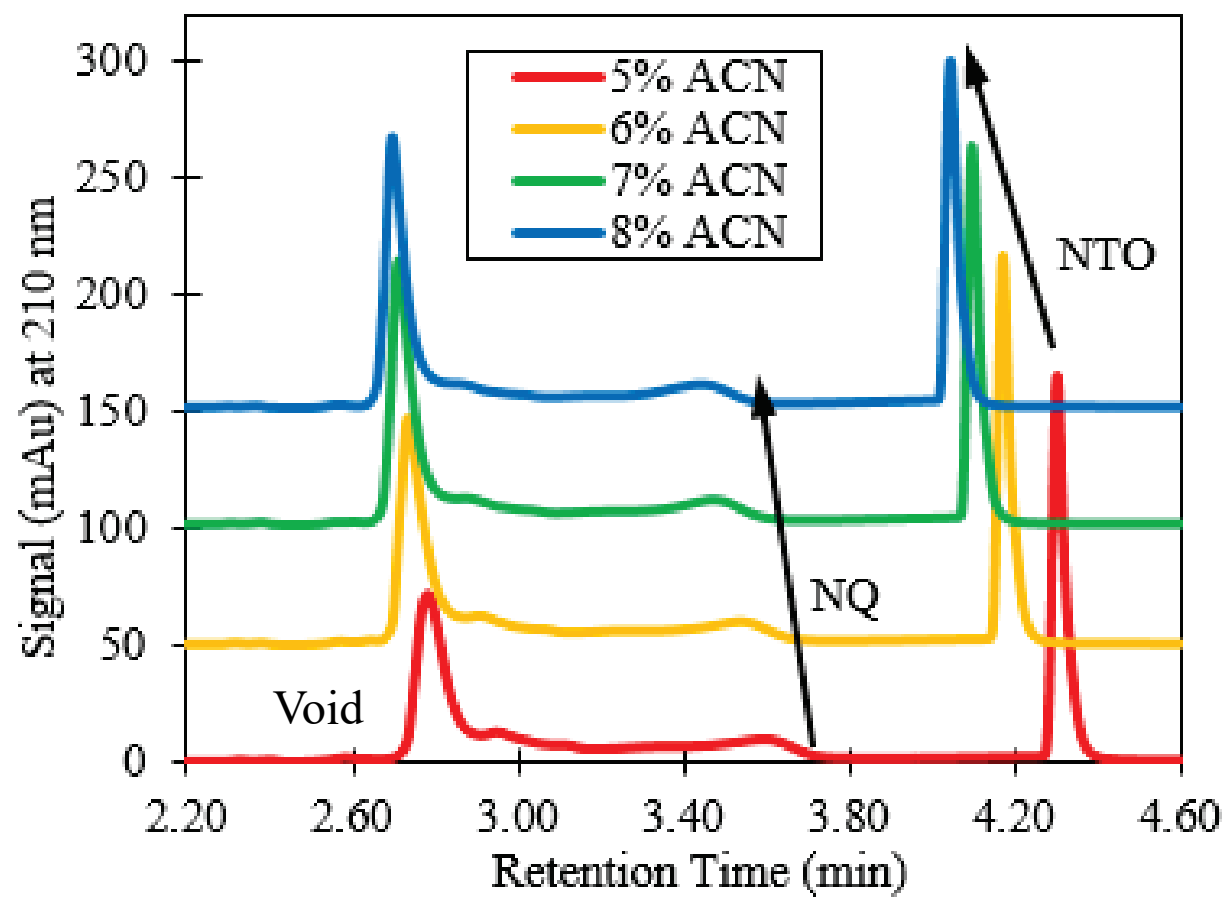

(a)

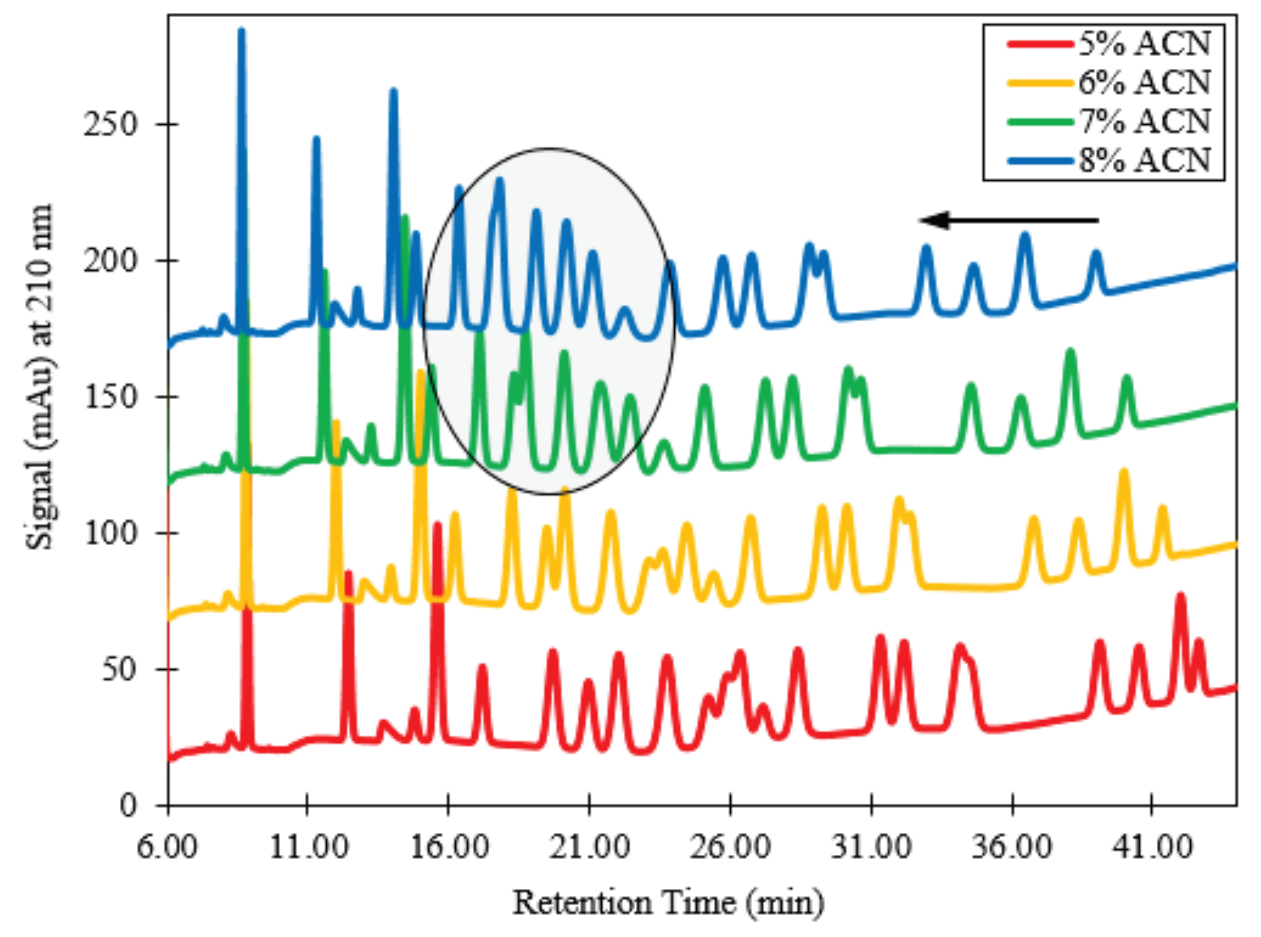

(b) 
Figure 8. Effect of introducing an ACN gradient from 6\%-20\% over the period 28-44 min. Red: HPLC-UV chromatogram resulting from ACN gradient method; yellow: ACN composition (\%); blue: HPLC-UV chromatogram resulting from $6 \%$ isocratic ACN

(without ACN gradient).

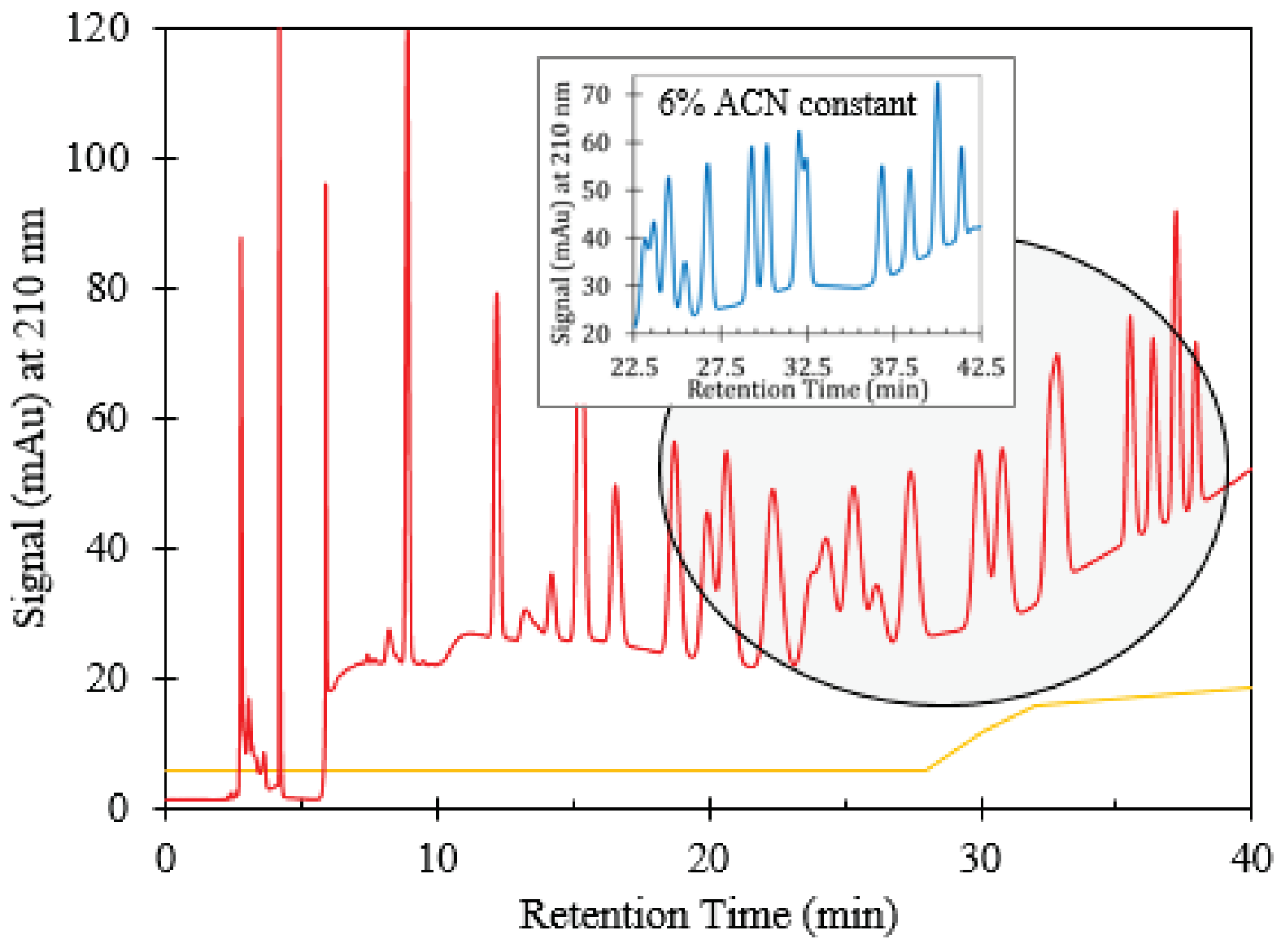


Figure 9. Effect of varying the sample solvent composition $\% \mathrm{MeOH}$ from $0 \%$ to $100 \%$, using the developed primary HPLC-UV method to analyze $5 \mathrm{mg} / \mathrm{L}$ mixed standards containing all 24 compounds of interest and 1,2-DNB surrogate prepared with indicated $\mathrm{MeOH} /$ water solvent ratios. (a) Effect on NQ and NTO, (b) effect on middleand late-eluting compounds.

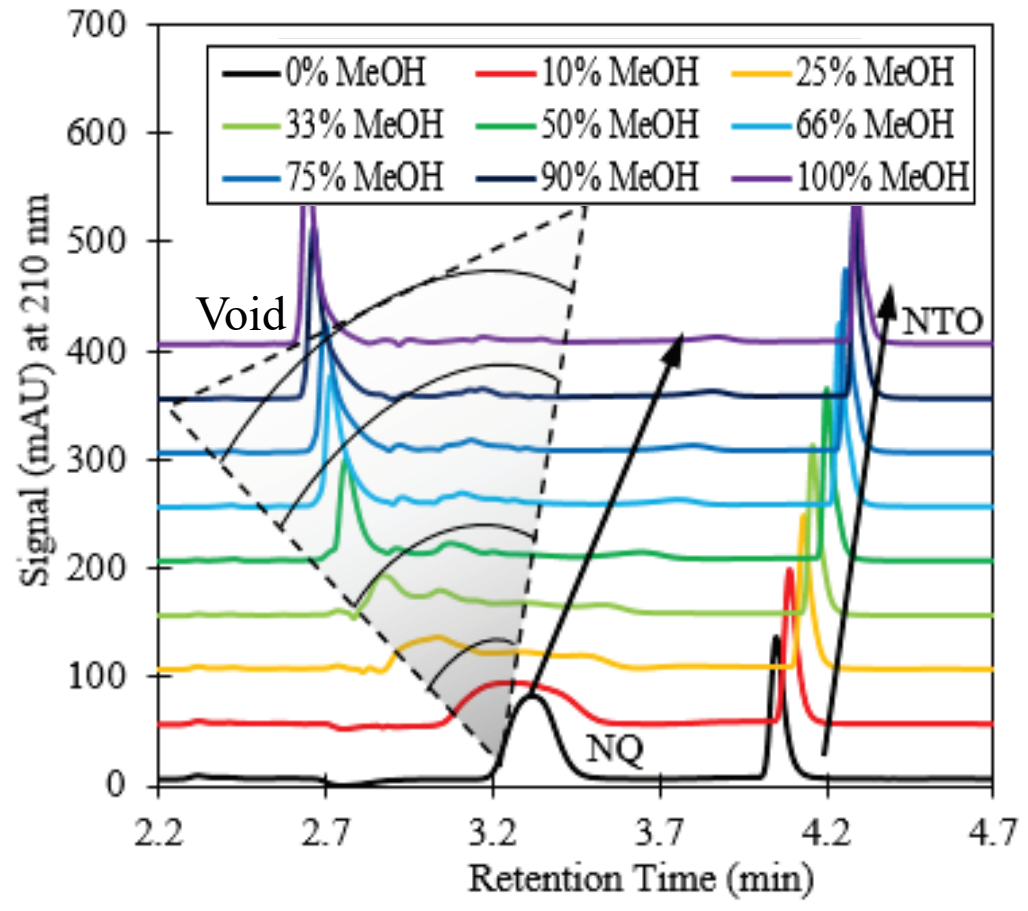

(a)

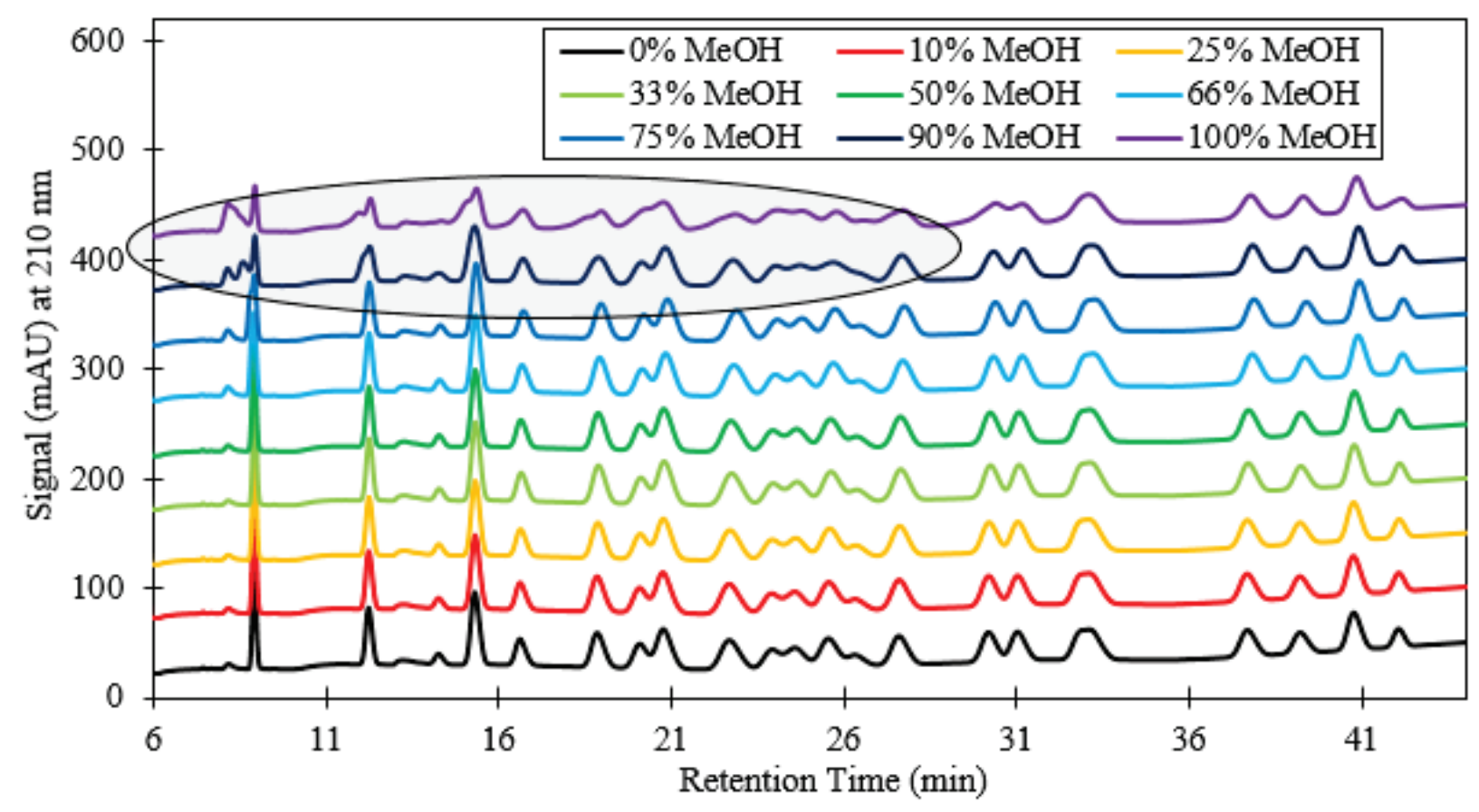

(b) 


\subsection{Secondary HPLC-UV method}

A secondary HPLC-UV method was developed to enable confirmatory analysis of the 24 legacy and IM compounds of interest and 2 surrogates. The solvent gradient scheme and other method parameters are shown in Table 3, and an example chromatogram is shown in Figure 2 (with peak assignments determined using individual reference standards), in section 2.2.

A graphical representation of the solvent gradient scheme for the secondary HPLC-UV method is shown in Figure 10. The initial portion of the gradient (o-2.5 min) was designed to elute the highly polar NQ and NTO. The next stage consists of a brief isocratic period (2.5-9 $\mathrm{min}$ ), followed by a spike and then a gradual decrease of the percentage of $\mathrm{MeOH}$ (9-15 min), was designed to elute and resolve the more hydrophobic compounds. The third stage of the gradient (15-29 min), with an increase to $60 \% \mathrm{MeOH}$ composition, was designed to elute the most hydrophobic compounds, decrease their retention times, and reduce overall method run time. A brief period at the end of the method returned the system to initial conditions to re-equilibrate before the next sample injection.

Three difficulties were addressed during the development of this method. Initially, (1) PA eluted within a void peak (6.5 $\mathrm{min}$ ) resulting from a sharp shift in aqueous-to-organic ratio at $4.1 \mathrm{~min}$ (rather than the final $2.6 \mathrm{~min}$ ), visible at $210 \mathrm{~nm}$; (2) HMX, 4-NP, and RDX co-eluted with each other; and, (3) NQ was poorly resolved at $210 \mathrm{~nm}$. To mitigate these issues, the isocratic percentage of $0.1 \% \mathrm{TFA} /$ water and percentage of $\mathrm{ACN}$ were optimized, and small adjustments to solvent gradient timing and the percentage of $\mathrm{MeOH}$ shifts were tested. By making slight changes in the percentage of $\mathrm{MeOH}$ gradient, the HMX, 4-NP, and RDX became well resolved. While NQ and PA became better resolved through solvent gradient method optimization, the issues with their chromatography were not eliminated. Therefore, an alternative option for improved chromatography could be to use alternate detection wavelengths, such as $254 \mathrm{~nm}$ for NQ and $315 \mathrm{~nm}$ for PA, rather than using $210 \mathrm{~nm}$, where void peaks did not appear, as these wavelengths were distant enough from the $\mathrm{MeOH}$ UV cutoff (205 $\mathrm{nm}$ ) and should result in acceptable detection limits. 
Figure 10. Secondary HPLC-UV method solvent gradient scheme developed for simultaneous confirmatory analysis of legacy and IM compounds.

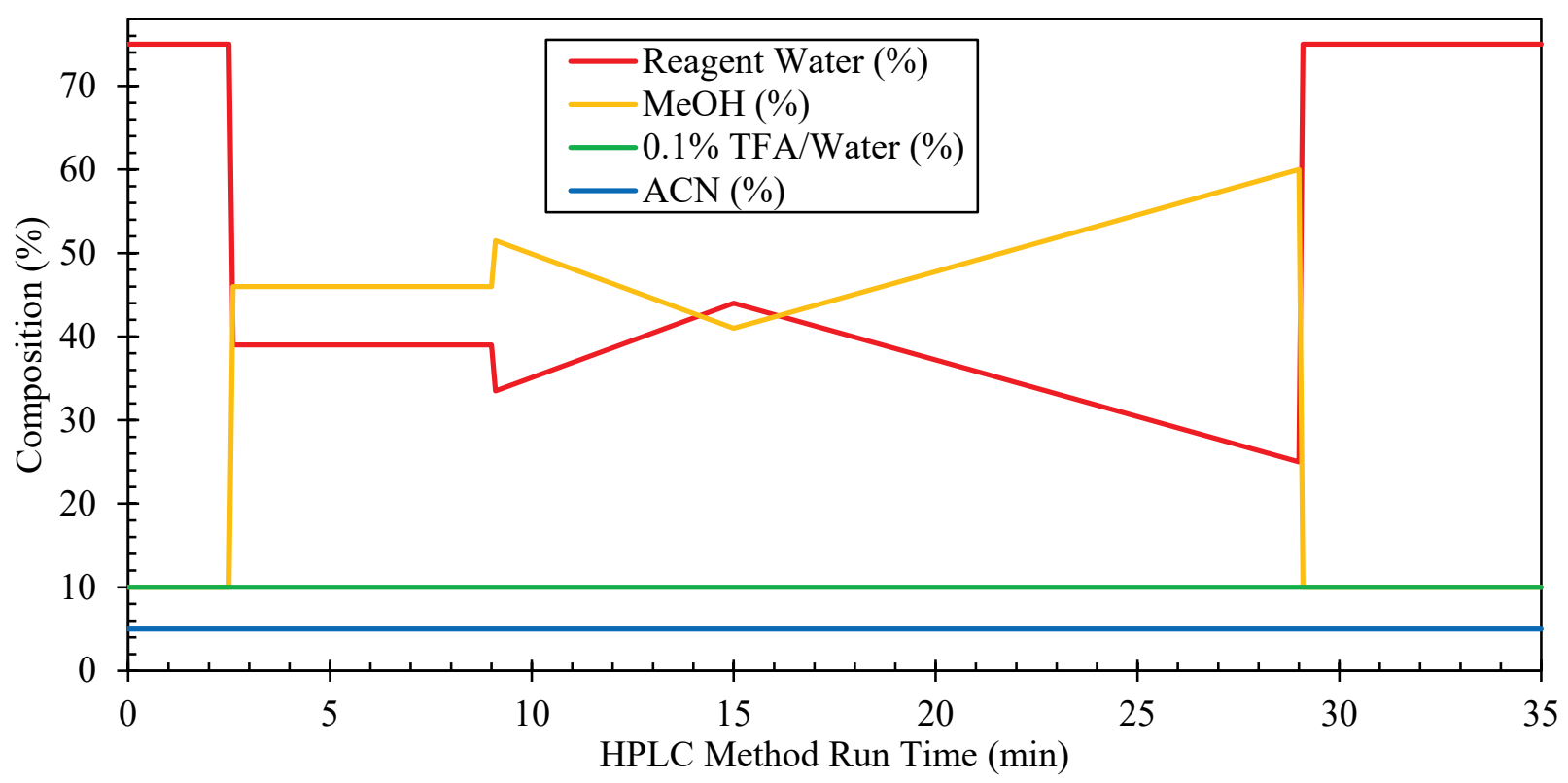

\subsection{HPLC-MS method}

An HPLC-MS scan mode method was developed to enable confirmatory analysis of the 24 legacy and IM compounds of interest and 2 surrogates. The solvent gradient scheme and other HPLC method parameters were unchanged from the primary HPLC-UV method described in section 2.3.

Efforts were made to transfer the LC-MS scan method to a selective-ion monitoring (SIM) method to improve detection limits by selectively detecting either one or two of the ion masses observed for each compound in scan mode experiments. The experimentally acquired ion masses obtained using the developed scan mode method, described in section 2.3 (Table 5 and Figure 3), were used to create ion-time windows for a SIM method. Several iterations with varying numbers of windows and times were attempted, with the most successful shown in Table 7 and Figure 11. The only other parameter that was changed from the scan mode method for the chromatogram shown in Figure 11 was the gain (2.0), which was increased to boost the signal. The peak width setting of $0.06 \mathrm{~min}$ resulted in total dwell times of between 330 and $345 \mathrm{msec}$ per SIM group, which was equally divided among the SIM ions in each group, as a fixed function of the system's software. Retention times were approximately the same as those for the scan mode method (Table 5). The compounds in SIM Group 1 (NQ, NTO, o-NBA, and HMX) were not observed. Most compounds in SIM 
Groups 2 and 4 were detected well, except for PA, 2,4-DNP, NB, and NG, which were not observed. Meanwhile, all the compounds in SIM Group 3 were observed. For SIM Groups 5 and 6, just one compound each was observed, 4-Am-2,6-DNT and PETN, respectively. Because of the issues encountered during SIM mode method development, confirmatory analysis should be performed using the scan mode method.

Table 7. Selective-ion monitoring (SIM) windows developed from UV peak retention times ( $\mathrm{min}$ ) and ion masses $(\mathrm{m} / \mathrm{z}$ ) observed using the developed scan mode method.

\begin{tabular}{|c|c|c|c|c|}
\hline $\begin{array}{l}\text { SIM window } \\
\text { start time } \\
\text { (min) }\end{array}$ & $\begin{array}{c}\text { SIM } \\
\text { window } \\
\text { group \# }\end{array}$ & Compound & $\begin{array}{c}\text { SIM ion } \\
(m / z)\end{array}$ & $\begin{array}{l}\text { Dwell } \\
\text { time } \\
\text { (ms) }\end{array}$ \\
\hline \multirow{8}{*}{0.00} & \multirow{8}{*}{1} & $N Q(1)$ & 203.6 & 42 \\
\hline & & $N Q(2)$ & 103.0 & 42 \\
\hline & & NTO (1) & 129.0 & 42 \\
\hline & & NTO (2) & 55.0 & 42 \\
\hline & & o-NBA (surr.) (1) & 122.0 & 42 \\
\hline & & o-NBA (surr.) (2) & 167.0 & 42 \\
\hline & & $\operatorname{HMX}(1)$ & 341.0 & 42 \\
\hline & & $\operatorname{HMX}(2)$ & 147.0 & 42 \\
\hline \multirow{9}{*}{11.50} & \multirow{9}{*}{2} & $\operatorname{RDX}(1)$ & 267.0 & 37 \\
\hline & & $\operatorname{RDX}(2)$ & 335.0 & 37 \\
\hline & & 4-NP(1) & 138.0 & 37 \\
\hline & & 4-NP(2) & 108.0 & 37 \\
\hline & & 1,3,5-TNB (1) & 213.0 & 37 \\
\hline & & 1,3,5-TNB (2)/2,4-DNP (1) & 183.0 & 37 \\
\hline & & 2,4-DNP (2) & 153.0 & 37 \\
\hline & & $P A(1)$ & 228.0 & 37 \\
\hline & & $P A(2)$ & 211.9 & 37 \\
\hline \multirow{3}{*}{20.50} & \multirow{3}{*}{3} & 1,2-DNB (surr.) (1)/2-NP (1) & 138.0 & 115 \\
\hline & & 1,2-DNB (surr.) (2)/1,3-DNB (1) & 168.0 & 115 \\
\hline & & $2-N P(2)$ & 122.1 & 115 \\
\hline \multirow{3}{*}{25.50} & \multirow{3}{*}{4} & NB (1)/3,5-DNA (1) & 182.0 & 37 \\
\hline & & NB (2) & 153.0 & 37 \\
\hline & & 3,5-DNA (2) & 138.0 & 37 \\
\hline
\end{tabular}




\begin{tabular}{|c|c|c|c|c|}
\hline $\begin{array}{l}\text { SIM window } \\
\text { start time } \\
\text { (min) }\end{array}$ & $\begin{array}{c}\text { SIM } \\
\text { window } \\
\text { group \# }\end{array}$ & Compound & $\begin{array}{c}\text { SIM ion } \\
(\mathrm{m} / \mathrm{z})\end{array}$ & $\begin{array}{l}\text { Dwel } \\
\text { time } \\
\text { (ms) }\end{array}$ \\
\hline & & DNAN (1) & 183.0 & 37 \\
\hline & & DNAN (2) & 152.9 & 37 \\
\hline & & Tetryl (1) & 241.0 & 37 \\
\hline & & Tetryl (2) & 288.0 & 37 \\
\hline & & 2,4,6-TNT (1)/NG (not obsv.) & 226.0 & 37 \\
\hline & & 2,4,6-TNT (2) & 210.0 & 37 \\
\hline \multirow{8}{*}{32.50} & \multirow{8}{*}{5} & 4-Am-2,6-DNT (1) & 196.9 & 42 \\
\hline & & 4-Am-2,6-DNT (2) & 167.0 & 42 \\
\hline & & 2-Am-4,6-DNT (1) & 196.0 & 42 \\
\hline & & 2-Am-4,6-DNT (2) & 179.9 & 42 \\
\hline & & 2,6-DNT (1) & 152.0 & 42 \\
\hline & & 2,6-DNT (2) & 122.1 & 42 \\
\hline & & 2,4-DNT (1) & 165.0 & 42 \\
\hline & & 2,4-DNT (2) & 181.0 & 42 \\
\hline \multirow{3}{*}{40.00} & \multirow{3}{*}{6} & 2-NT/3-NT/4-NT (not obsv.) & 136.1 & 115 \\
\hline & & PETN (1) & 62.0 & 115 \\
\hline & & PETN (2) & 270.9 & 115 \\
\hline
\end{tabular}

Bold, italicized are IM compounds and degradation products.

*SIM window start time = LC-MS method run time (no MS delay) 
Figure 11. HPLC-MS TIC acquired by SIM mode method. SIM window start times are indicated by dotted lines, and SIM group numbers are noted above the plot area.

(Retention times are listed in Table 7.)

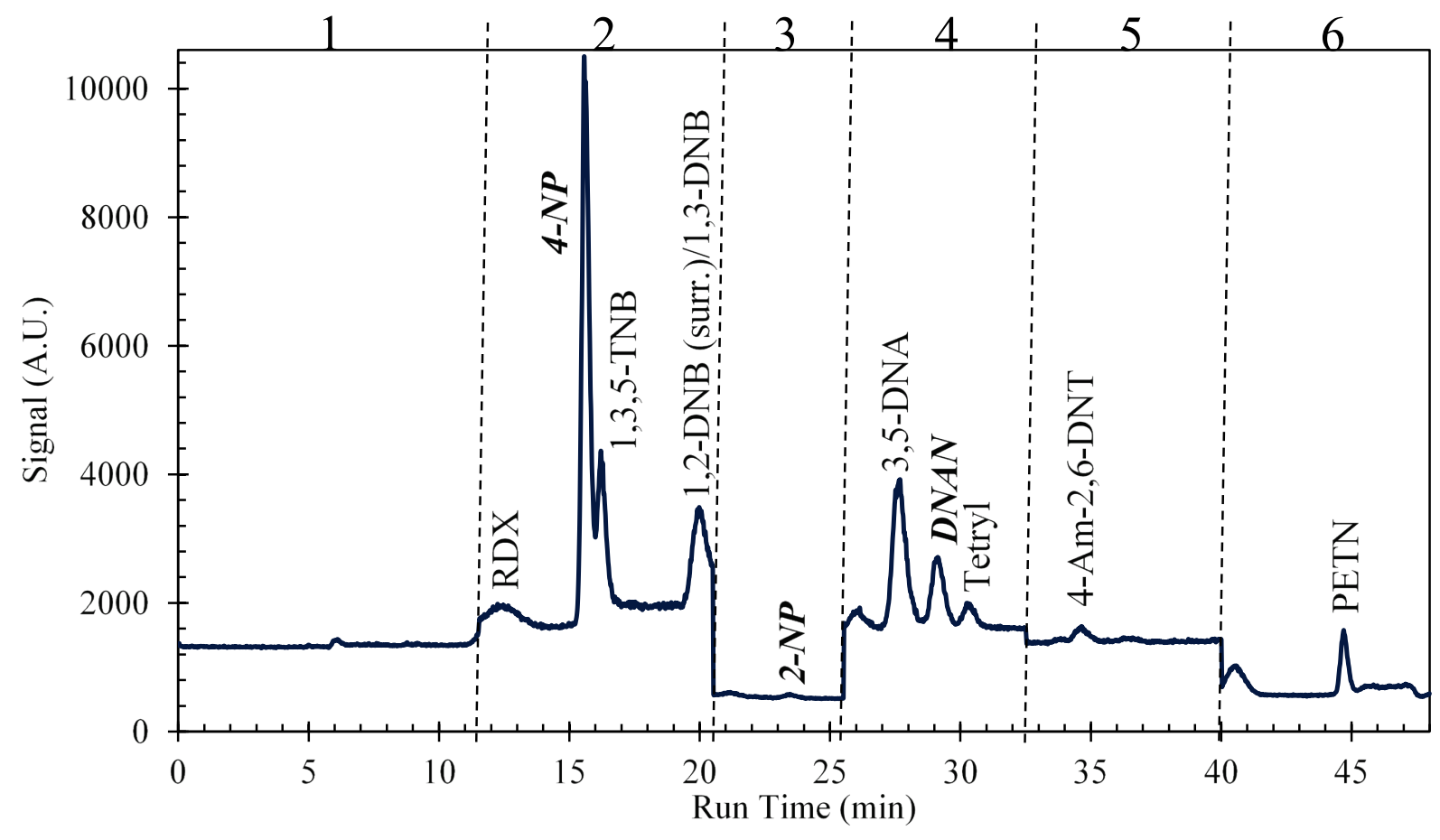

Bold, italicized are IM compounds and degradation products.

\subsection{Method for preparation of waters for direct-injection analysis}

During the direct-injection water portion of the interlaboratory study (section 3.10), much lower recoveries for NTO, and in some cases $o$-NBA surrogate, were observed for field water samples than for reagent water. As this trend seemed related to $\mathrm{pH}$, with NTO recovery being lower for higher-pH water samples (Table 8), further experiments were carried out in which the $\mathrm{pH}$ of samples to be analyzed by direct injection was adjusted. A solution of $2 \% \mathrm{HCl} / \mathrm{MeOH}$ (the same used for stage two of SPE elution) was used, for final acid concentrations equal (0.5\%, v/v) or double ( $1 \%$, $\mathrm{v} / \mathrm{v}$ ) that of corresponding SPE extracted and preconcentrated samples. Recovery results for the acidified direct-injection water samples are shown in Table 9. For each field water source, acidification with $\mathrm{HCl}$ resulted in near $100 \%$ recovery for NTO and $o$-NBA. Moreover, an acid concentration of $0.5 \%$ was sufficient, and $1 \%$ acid was not necessary. Therefore, for water samples with $\mathrm{pH} \geq 6.5$ (approximately) to be analyzed by direct injection, acidification is recommended. Furthermore, for higher-pH samples extracted and preconcentrated by SPE that are known or suspected to 
contain NTO, additional acidification may also be necessary (as for the pH 9.2 tap water used in the current study).

Table 8. Characteristic properties of five water sources used in interlaboratory batch studies. (AVG = average; SD = standard deviation)

\begin{tabular}{|c|c|c|c|c|c|c|}
\hline \multirow[b]{2}{*}{ Water source } & \multirow[b]{2}{*}{$\mathrm{pH}$} & \multirow[b]{2}{*}{$\begin{array}{c}\text { Conductivity } \\
(\mu \mathrm{S} / \mathrm{cm})\end{array}$} & \multicolumn{2}{|c|}{$\begin{array}{l}\text { Total organic carbon } \\
\text { (TOC) }(\mathrm{mg} / \mathrm{L})\end{array}$} & \multicolumn{2}{|c|}{$\begin{array}{c}\text { Total dissolved solids } \\
\text { (TDS) (mg/L) }\end{array}$} \\
\hline & & & $\begin{array}{l}\text { AVG } \\
(n=3)\end{array}$ & Std Dev & $\begin{array}{c}\text { AVG } \\
(n=3)\end{array}$ & SD \\
\hline Reagent (ERDC-EL) & 6.30 & 3.53 & 0.00 & 0.00 & -11 & 1.2 \\
\hline Tap (Vicksburg, MS) & 9.16 & 208.1 & 1.11 & 0.12 & 125 & 1.2 \\
\hline Ground (Rayville, LA) & 8.10 & 456.6 & 1.31 & 0.33 & 264 & 3.3 \\
\hline $\begin{array}{c}\text { Yazoo River } \\
\text { (Vicksburg, MS) }\end{array}$ & 8.22 & 254.2 & 5.62 & 0.03 & 198 & 2.0 \\
\hline $\begin{array}{c}\text { Sea (Houston } \\
\text { Shipping Channel) }\end{array}$ & 7.84 & 13,350 & 5.14 & 0.05 & 8,910 & 7.2 \\
\hline
\end{tabular}


Table 9. Recoveries (\%) for five water samples acidified using $2 \% \mathrm{HCl} / \mathrm{MeOH}$ and analyzed by direct injection without undergoing SPE. ( $\mathrm{AVG}=$ average; $\mathrm{SD}=$ standard deviation)

\begin{tabular}{|c|c|c|c|c|c|c|c|c|c|c|c|c|c|c|c|c|c|c|c|c|}
\hline \multirow[b]{4}{*}{ Compound } & \multicolumn{20}{|c|}{ Recoveries (\%) } \\
\hline & \multicolumn{10}{|c|}{$0.5 \% \mathrm{HCl}(\mathrm{vol} / \mathrm{vol})$} & \multicolumn{10}{|c|}{$1 \% \mathrm{HCl}$ (vol/vol) } \\
\hline & \multicolumn{2}{|c|}{ Reagent water } & \multicolumn{2}{|c|}{ Tap water } & \multicolumn{2}{|c|}{$\begin{array}{l}\text { Yazoo River } \\
\text { water }\end{array}$} & \multicolumn{2}{|c|}{$\begin{array}{l}\text { Houston } \\
\text { Shipping } \\
\text { Channel water }\end{array}$} & \multicolumn{2}{|c|}{ Well water } & \multicolumn{2}{|c|}{ Reagent water } & \multicolumn{2}{|c|}{ Tap water } & \multicolumn{2}{|c|}{$\begin{array}{l}\text { Yazoo River } \\
\text { water }\end{array}$} & \multicolumn{2}{|c|}{\begin{tabular}{|l|} 
Houston \\
Shipping \\
Channel water
\end{tabular}} & \multicolumn{2}{|c|}{ Well water } \\
\hline & $\begin{array}{l}\text { AVG } \\
(n=2)\end{array}$ & SD & $\begin{array}{l}\text { AVG } \\
(n=3)\end{array}$ & SD & $\begin{array}{l}\text { AVG } \\
(n=3)\end{array}$ & SD & $\begin{array}{l}\text { AVG } \\
(n=3)\end{array}$ & SD & $\begin{array}{l}\text { AVG } \\
(n=3)\end{array}$ & SD & $\begin{array}{l}\text { AVG } \\
(n=3)\end{array}$ & SD & $\begin{array}{l}\text { AVG } \\
(n=3)\end{array}$ & SD & $\begin{array}{l}\text { AVG } \\
(n=3)\end{array}$ & SD & $\begin{array}{l}\text { AVG } \\
(n=3)\end{array}$ & SD & $\begin{array}{l}\text { AVG } \\
(n=3)\end{array}$ & SD \\
\hline$N Q$ & 99 & 5.4 & 110 & 2.2 & 101 & 2.2 & 107 & 7.4 & 101 & 6.4 & 109 & 6.1 & 108 & 12.2 & 120 & 14.4 & 112 & 17.6 & 106 & 19.0 \\
\hline NTO $(210 \mathrm{~nm})$ & 111 & 10.4 & 114 & 3.9 & 117 & 7.0 & 119 & 2.4 & 111 & 8.0 & 118 & 9.9 & 108 & 6.5 & $132^{*}$ & 15.6 & $125^{*}$ & 21.4 & 112 & 11.0 \\
\hline NTO $(315 \mathrm{~nm})$ & 110 & 14.7 & 112 & 6.2 & 120 & 3.9 & 121 & 3.8 & 114 & 4.6 & 121 & 10.2 & 113 & 6.2 & $131^{*}$ & 15.6 & 121 & 20.4 & 117 & 11.2 \\
\hline o-NBA (surrogate) & 94 & 9.0 & 98 & 5.8 & 98 & 5.8 & 99 & 1.9 & 96 & 7.1 & 104 & 4.1 & 104 & 8.5 & 112 & 11.9 & 102 & 17.2 & 102 & 11.6 \\
\hline HMX & 94 & 9.1 & 97 & 5.4 & 95 & 5.9 & 98 & 4.2 & 94 & 0.9 & 101 & 10.1 & 98 & 8.1 & 106 & 16.0 & 97 & 17.3 & 94 & 10.2 \\
\hline $\mathrm{RDX}$ & 96 & 12.3 & 100 & 4.0 & 95 & 6.7 & 100 & 1.1 & 96 & 6.2 & 101 & 6.7 & 102 & 10.4 & 109 & 17.7 & 102 & 17.5 & 99 & 9.6 \\
\hline$P A(210 n m)$ & 83 & 5.4 & 93 & 4.5 & 87 & 6.3 & 87 & 8.6 & 89 & 6.3 & 95 & 10.8 & 98 & 7.2 & 104 & 23.7 & 105 & 23.6 & 97 & 8.7 \\
\hline$P A(315 n m)$ & 91 & 8.0 & 96 & 5.2 & 93 & 7.0 & 93 & 5.1 & 90 & 7.8 & 97 & 6.0 & 97 & 8.6 & 106 & 14.0 & 98 & 18.8 & 95 & 10.0 \\
\hline 4-NP & 95 & 12.0 & 98 & 5.1 & 99 & 6.1 & 99 & 4.8 & 94 & 6.3 & 99 & 6.7 & 95 & 8.9 & 108 & 14.1 & 100 & 17.2 & 96 & 10.5 \\
\hline $1,3,5-\mathrm{TNB}$ & 92 & 10.9 & 98 & 3.0 & 96 & 4.8 & 96 & 3.3 & 92 & 4.5 & 97 & 6.1 & 98 & 5.3 & 105 & 15.4 & 98 & 17.9 & 94 & 8.9 \\
\hline 2,4-DNP & 86 & 9.6 & 93 & 7.7 & 92 & 5.9 & 94 & 7.3 & 87 & 3.8 & 100 & 3.2 & 92 & 11.2 & 107 & 13.6 & 94 & 18.2 & 92 & 10.6 \\
\hline $\begin{array}{r}1,2-\mathrm{DNB} \\
\text { (surrogate) }\end{array}$ & 91 & 11.0 & 98 & 6.5 & 92 & 5.0 & 96 & 3.6 & 93 & 2.9 & 97 & 9.0 & 98 & 10.1 & 110 & 13.8 & 100 & 18.6 & 94 & 14.0 \\
\hline 1,3-DNB & 92 & 11.2 & 100 & 7.4 & 95 & 4.5 & 96 & 3.4 & 91 & 4.6 & 103 & 12.1 & 99 & 7.2 & 107 & 13.5 & 99 & 17.5 & 96 & 10.8 \\
\hline $2-N P$ & 88 & 13.5 & 92 & 6.8 & 92 & 5.9 & 92 & 4.1 & 88 & 2.4 & 90 & 4.5 & 84 & 9.6 & 99 & 17.7 & 95 & 13.1 & 91 & 9.7 \\
\hline NB & 88 & 107.0 & 85 & 6.8 & 90 & 7.4 & 92 & 2.0 & 88 & 5.1 & 94 & 5.2 & 82 & 6.0 & 103 & 14.7 & 96 & 19.4 & 93 & 9.9 \\
\hline 3,5-DNA (210nm) & 106 & 12.4 & 109 & 6.6 & 101 & 4.9 & 106 & 3.1 & 98 & 3.7 & 102 & 1.1 & 103 & 11.4 & 115 & 17.1 & 106 & 18.1 & 102 & 10.8 \\
\hline 3,5 -DNA $(254 \mathrm{~nm})$ & 107 & 11.8 & 111 & 8.5 & 106 & 5.7 & 109 & 1.9 & 104 & 2.1 & 108 & 4.6 & 107 & 9.1 & 119 & 18.0 & 109 & 17.5 & 105 & 10.1 \\
\hline$D N A N$ & 87 & 12.3 & 92 & 5.0 & 86 & 3.9 & 88 & 2.1 & 83 & 3.8 & 89 & 3.6 & 89 & 6.8 & 96 & 16.6 & 95 & 15.4 & 88 & 11.2 \\
\hline Tetryl & 94 & 7.5 & 99 & 3.5 & 96 & 5.1 & 97 & 5.6 & 95 & 7.1 & 98 & 4.4 & 104 & 15.7 & 111 & 13.9 & 101 & 18.5 & 97 & 9.4 \\
\hline NG & 106 & 5.0 & 103 & 8.3 & 112 & 2.8 & 99 & 8.3 & 109 & 4.6 & 112 & 11.5 & 113 & 18.9 & $127^{*}$ & 9.7 & 118 & 15.4 & 108 & 9.6 \\
\hline 2,4,6-TNT & 92 & 6.7 & 99 & 6.8 & 94 & 8.0 & 93 & 3.9 & 94 & 0.4 & 95 & 6.0 & 100 & 15.5 & 110 & 10.5 & 100 & 20.3 & 93 & 10.1 \\
\hline 4-Am-2,6-DNT & 93 & 11.0 & 80 & 4.4 & 95 & 7.0 & 98 & 6.4 & 94 & 7.6 & 96 & 8.3 & 76 & 9.2 & 108 & 14.5 & 100 & 18.6 & 95 & 11.8 \\
\hline 2-Am-4,6-DNT & 93 & 11.4 & 83 & 2.3 & 95 & 5.6 & 102 & 4.6 & 99 & 1.8 & 99 & 8.7 & 85 & 9.5 & 108 & 16.1 & 101 & 20.0 & 94 & \begin{tabular}{|l|}
11.1 \\
\end{tabular} \\
\hline 2,6-DNT & 92 & 8.4 & 93 & 5.8 & 95 & 2.1 & 102 & 7.1 & 89 & 4.4 & 95 & 5.1 & 96 & 7.0 & 109 & 17.0 & 102 & 21.2 & 95 & 10.2 \\
\hline 2,4-DNT & 88 & 9.5 & 97 & 4.3 & 96 & 6.6 & 98 & 6.3 & 94 & 4.8 & 103 & 6.5 & 98 & 8.8 & 107 & 13.1 & 99 & 19.2 & 96 & 12.0 \\
\hline 2-NT & 98 & 8.9 & 104 & 1.2 & 98 & 6.3 & 101 & 2.4 & 95 & 2.2 & 101 & 4.5 & 98 & 6.5 & 103 & 27.0 & 100 & 16.2 & 95 & 11.4 \\
\hline 4-NT & 91 & 8.2 & 97 & 4.6 & 91 & 5.8 & 95 & 5.7 & 92 & 6.4 & 96 & 7.3 & 91 & 8.7 & 114 & 12.7 & 95 & 14.1 & 94 & 10.6 \\
\hline 3-NT & 97 & 13.8 & 101 & 3.3 & 95 & 6.1 & 99 & 6.3 & 92 & 4.3 & 96 & 1.1 & 98 & 4.7 & 107 & 15.8 & 97 & 14.8 & 95 & \begin{tabular}{|l|}
9.5 \\
\end{tabular} \\
\hline PETN & 99 & 13.3 & 106 & 7.7 & 101 & 6.6 & 98 & 7.5 & 94 & 7.2 & 97 & 12.7 & 110 & 4.8 & 110 & 11.8 & 100 & 19.0 & 94 & 9.1 \\
\hline
\end{tabular}

(D) 


\subsection{SPE method for waters}

Current USEPA Method 8330B and ERDC-EL SPE methods were modified to enable extraction and preconcentration of all 24 compounds of interest (and 2 surrogates) from environmental water samples. A series of cation-exchange, anion-exchange, reverse phase, and GAC-based SPE cartridges were evaluated using slightly modified SPE methods for environmental water extraction and preconcentration. The ability of each cartridge, individually or sequentially, to recover the 24 compounds of interest and 2 surrogates from laboratory-spiked reagent water samples was compared.

The results in Table 10 show the varying abilities of seven individual SPE cartridges to extract and preconcentrate 25 compounds (prior to addition of the second surrogate, $o$-NBA). The individual cartridges compared in this experiment were (from left to right in the table) (1) Strata X (polymeric reverse phase, $500 \mathrm{mg} / 6 \mathrm{~mL}$, Phenomenex, PRP500); (2) ENVI-18 (traditional C-18, 1 g/6 mL, Supelclean, C181G); (3) Strata X-A (polymeric strong anion exchange, $200 \mathrm{mg} / 6 \mathrm{~mL}$, Phenomenex, PSA200); (4) Strata X-A (polymeric strong anion exchange, $500 \mathrm{mg} / 6 \mathrm{~mL}$, Phenomenex, PSA500); (5) ENVI-Carb (GAC, $250 \mathrm{mg} / 3 \mathrm{~mL}$, Supelclean, GAC250); (6) Strata ABW (mixed mode strong cation exchange (4ethylbenzene sulfonate) and weak anion exchange (propylamine), 200 mg/3 mL, Phenomenex, ABW200); and (7) a new Phenomenex GAC cartridge undergoing product testing $\left(500 \mathrm{mg} / 6 \mathrm{~mL}, \mathrm{ACP}_{500}\right)$.

Overall, the reverse phase (PRP500 and $\mathrm{C} 181 \mathrm{G}$ ) and anion exchange (PSA200 and PSA500) tested were able to extract most compounds within DoD QSM Ver5.2 limits. The GAC250 was also able to extract many compounds, but fewer than the reverse phase and anion exchange. In some cases, particularly for the acidic compounds, when recoveries were low, mass balance analysis indicated that the compounds were effectively adsorbed onto cartridges but failed to elute. On the other hand, NQ tended to be the only compound that was poorly adsorbed onto any individual cartridge. Of the seven individual cartridges, ABW20o performed best for NQ with 61\% recovery; however, this result proved to be irreproducible.

The ABW200 and ACP500 cartridges did not recover many analytes within accepted ranges and so were not included in further studies. Aside from ABW200, GAC250 performed best for NQ, with $30 \%$ recovery. 
Meanwhile, PSA500 was twice as effective as PSA200 for NQ recovery (11\% versus 6\%), and PRP500 was better than $\mathrm{C} 181 \mathrm{G}$ for NQ (10\% versus $5 \%$ ), NTO ( $3 \%$ versus $1 \%$ ), and PA (102\% versus $11 \%$ ) recovery.

Furthermore, both of the PSA cartridges were able to recover all of the remaining compounds within DoD QSM Ver5.2 limits (apart from the anomalously high NG recoveries for this experiment). The PRP5OO and C181G failed only to recover NTO or NTO and PA, respectively, indicating that inclusion of an anion exchange cartridge would be important for extraction of the highly acidic compounds.

On the basis of the results with individual cartridges, several double- and triple-stacked options were tested, to identify a sequential option that yielded acceptable recoveries for all compounds. The stacking order for sample loading and elution was reversed to prevent irreversible binding of analytes to incompatible SPE cartridge matrices, which was observed during evaluation of individual cartridges. In addition, two sizes of ENVICarb cartridges were tested, the $250 \mathrm{mg} / 3 \mathrm{~mL}$ (GAC250) and a larger 500 $\mathrm{mg} / 6 \mathrm{~mL}$ (GAC500). Results for six stacked options are shown in Table 9, where loading-stage stacking order from top to bottom is indicated, including (A) PRP500-PSA500-GAC250, (B) PRP500-PSA500-GAC500, (C) C181G-PSA500-GAC250, (D) C181G-PSA500-GAC500, (E) PSA5O0C181G-GAC250, and (F) PSA500-GAC250.

Table 10. Compound recoveries from laboratory-spiked reagent water samples using individual SPE cartridges for extraction/preconcentration of the 24 compounds of interest and 1,2-DNB surrogate.

\begin{tabular}{|c|c|c|c|c|c|c|c|}
\hline \multirow[b]{2}{*}{ Compound } & \multicolumn{7}{|c|}{ Recoveries (\%) } \\
\hline & PRP500 & C181G & PSA200 & PSA500 & GAC250 & ABW200 & ACP500 \\
\hline$N Q$ & $10+$ & $5+$ & $6+$ & $11 \dagger$ & $30+$ & $61^{*}$ & $2 \uparrow$ \\
\hline NTO $(210 \mathrm{~nm})$ & $3+$ & $1 \dagger$ & 120 & 118 & 123 & $2 \uparrow$ & $235+$ \\
\hline HMX & 113 & 104 & 118 & 118 & 118 & 88 & 27 \\
\hline $\mathrm{RDX}$ & 112 & 115 & 113 & 113 & 116 & 102 & 1 \\
\hline$P A(210 \mathrm{~nm})$ & 102 & $11 \dagger$ & 119 & 113 & $1 \dagger$ & $N D+$ & 102 \\
\hline 4-NP & 108 & 112 & 112 & 110 & 121 & $16+$ & $65^{\star}$ \\
\hline 1,3,5-TNB & 114 & 114 & 112 & 112 & 88 & $3+$ & $15+$ \\
\hline 2,4-DNP & 108 & 106 & $126^{\star}$ & 117 & $4 \dagger$ & $N D+$ & 102 \\
\hline 1,2-DNB (surr.) & 100 & 102 & 100 & 101 & 100 & 99 & $4 \dagger$ \\
\hline 1,3-DNB & 111 & 114 & 112 & 112 & 112 & $21 \dagger$ & $52 \dagger$ \\
\hline
\end{tabular}




\begin{tabular}{|c|c|c|c|c|c|c|c|}
\hline \multirow[b]{2}{*}{ Compound } & \multicolumn{7}{|c|}{ Recoveries (\%) } \\
\hline & PRP500 & C181G & PSA200 & PSA500 & GAC250 & ABW200 & ACP500 \\
\hline $2-N P$ & 95 & 97 & 95 & 96 & 95 & $56+$ & $49+$ \\
\hline NB & 112 & 114 & 112 & 113 & $19+$ & $9+$ & $\mathrm{ND} \dagger$ \\
\hline 3,5-DNA (254 nm) & 111 & 114 & 111 & 114 & 113 & 110 & $\mathrm{ND}+$ \\
\hline DNAN & 106 & 108 & 108 & 107 & 108 & $1 \dagger$ & $10+$ \\
\hline Tetryl & 112 & 115 & 81 & 81 & 105 & 86 & $6+$ \\
\hline$N G$ & 114 & 115 & $148+$ & $175 \dagger$ & 105 & 111 & $\mathrm{ND} \dagger$ \\
\hline 2,4,6-TNT & 110 & 113 & 104 & 105 & 79 & $8+$ & $28+$ \\
\hline 4-Am-2,6-DNT & 117 & 114 & 112 & 112 & 118 & $53+$ & $52 \dagger$ \\
\hline 2-Am-4,6-DNT & 115 & 115 & 112 & 113 & $6+$ & $13+$ & $\mathrm{ND}+$ \\
\hline 2,6-DNT & 113 & 118 & 115 & 108 & 115 & 100 & $24 \dagger$ \\
\hline 2,4-DNT & 105 & 98 & 100 & 119 & 113 & $2 \dagger$ & $21 \dagger$ \\
\hline 2-NT & 109 & 111 & 108 & 109 & 109 & 85 & $3+$ \\
\hline 4-NT & 109 & 113 & 110 & 109 & 109 & $59 *$ & $31 \dagger$ \\
\hline 3-NT & 109 & 112 & 110 & 110 & 109 & $75^{*}$ & $14 \dagger$ \\
\hline PETN & $126 *$ & 110 & 109 & 111 & 110 & 102 & $2 \dagger$ \\
\hline
\end{tabular}

Bold, italicized are IM compounds and degradation products. ND: not detected.

Green: $75 \%-125 \%$; light green (*): $57 \%-74 \%$ or $126 \%-35 \%$; red $(\dagger):<57 \%$ or $>135 \%$

(DoD QSM Ver5.2 for Waters-lowest LCL: MNX, 57\%; highest UCL: HMX, 135\%)

Table 11. Compound recoveries (\%) from laboratory-spiked reagent water samples using stacked SPE cartridges for extraction/preconcentration of the 24 compounds of interest and 1,2-DNB surrogate.

\begin{tabular}{|c|c|c|c|c|c|c|}
\hline & \multicolumn{6}{|c|}{ Recoveries (\%) } \\
\hline Compound & $\begin{array}{c}\text { A } \\
\text { PRP500 } \\
\text { I } \\
\text { PSA500 } \\
\text { I } \\
\text { GAC250 }\end{array}$ & $\begin{array}{c}\text { B } \\
\text { PRP500 } \\
\text { I } \\
\text { PSA500 } \\
\text { I } \\
\text { GAC500 }\end{array}$ & $\begin{array}{c}\text { C } \\
\text { C181G } \\
\text { I } \\
\text { PSA500 } \\
\text { I } \\
\text { GAC250 }\end{array}$ & $\begin{array}{c}\text { D } \\
\text { C181G } \\
\text { I } \\
\text { PSA500 } \\
\text { I } \\
\text { GAC500 }\end{array}$ & $\begin{array}{c}E \\
\text { PSA500 } \\
\text { I } \\
\text { C181G } \\
\text { I } \\
\text { GAC250 }\end{array}$ & $\begin{array}{c}F \\
\text { PSA500 } \\
\text { I } \\
\text { GAC250 }\end{array}$ \\
\hline$N Q$ & $2+$ & $19+$ & $48+$ & $4+$ & $43+$ & $38+$ \\
\hline NTO $(210 \mathrm{~nm})$ & 107 & 98 & 109 & 103 & 107 & 111 \\
\hline HMX & 97 & 95 & 117 & 102 & 113 & 110 \\
\hline RDX & 91 & 92 & 114 & 99 & 107 & 109 \\
\hline$P A(210 \mathrm{~nm})$ & 94 & 86 & 96 & $67 *$ & 102 & 101 \\
\hline
\end{tabular}




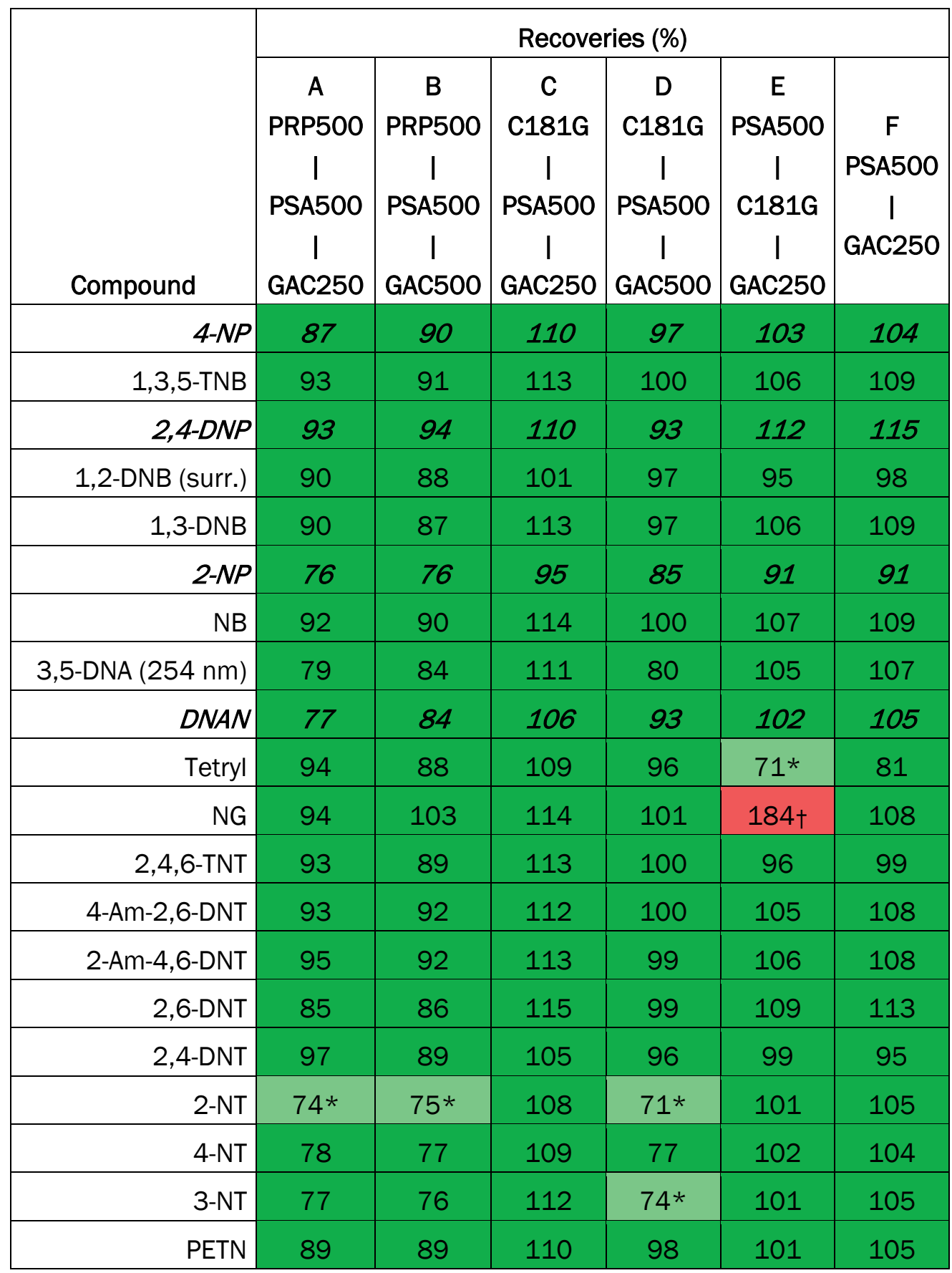

Bold, italicized are IM compounds and degradation products.

Green: $75 \%-125 \%$; light green (*): $57 \%-74 \%$ or $126 \%-135 \%$; red $(\dagger):<57 \%$ or $>135 \%$

(DoD QSM Ver5.2 for Waters-lowest LCL: MNX, 57\%; highest UCL: HMX, 135\%)

NQ recovery for each option was expected to be $\geq 50 \%$, on the basis of the recoveries for individual cartridges noted in Table 8 and the assumption of an additive relationship. While NQ recoveries for this particular experiment were not as high as expected, options B and C from Table 9 were selected for further tests. Although option F (PSA500-GAC250) also yielded higher recovery of NQ (38\%), triple-stacked options that included 
a reverse-phase cartridge were preferred for further studies as an added mechanism to ensure prevention of analyte breakthrough in more concentrated, larger volume or more complex matrix samples; however, this option (or PSA500-GAC500) may be acceptable in some cases to reduce method complexity. Furthermore, in cases where NQ is known or likely to be absent or not of interest, it may be acceptable to use a single PSA500 cartridge (Table 10).

Studies of the 24 compounds' and 2 surrogates' pre- and postextraction stability in laboratory-spiked reagent water samples were carried out using options B and C from Table 11. On the basis of the slightly better results for option B in the stability studies (Tables 24 and 25 in section 3.9), the PRP500-PSA500-GAC500 option was selected as the best multicartridge option for recovery of all compounds, with NQ recovery consistently approximately $50 \%$. There was also a laboratory process-based preference for GAC500 versus GAC250 in stacked options, as the reduced surface area and volume capacity of the GAC250 $(3 \mathrm{~mL})$ resulted in an increased time requirement for sample loading and complicated SPE conditioning and extract elution procedures. Therefore, option B was chosen for use in cross-laboratory batch tests of five different laboratory-spiked water samples (Table 29 in section 3.10).

\subsection{SE method for soils}

Current USEPA Method 8330B and ERDC-EL SE methods were modified to enable extraction of all 24 compounds of interest (and 2 surrogates) from environmental soil samples. Preliminary SE trials indicated that traditional USEPA Method 8330B solid matrix extraction methods (that is, extraction using ACN for a single $18 \mathrm{~h}$ ultrasonication period) would be insufficient to extract all 24 compounds of interest, supported by previous studies (Walsh et al. 2016; Felt et al. 2016). Therefore, several different solvents, ultrasonication times, and multistage extraction procedures were investigated.

Early trials compared single $18 \mathrm{~h}$ extractions of laboratory-spiked samples using either $\mathrm{MeOH}$ or ACN, according to USEPA Method $8330 \mathrm{~B}$ procedures, including spiking, drying, and ultrasonication. The majority of the method development was carried out using a standard soil, ASTM fat clay (CH-1). From the results of early trials, it became clear that using either $\mathrm{ACN}$ or $\mathrm{MeOH}$ alone would be insufficient to extract all compounds from soils at acceptable recovery rates. Table 12 compares compound 
recoveries for laboratory-spiked ASTM fat clay soil samples using either $\mathrm{MeOH}$ or $\mathrm{ACN}$ for either $1 \times 18 \mathrm{~h}$ or $2 \times 9 \mathrm{~h}$ ultrasonication periods, with no other modifications to USEPA Method 8330 B procedures of drying, sonicating, and filtering. For both $\mathrm{MeOH}$ and $\mathrm{ACN}$, splitting the ultrasonication period into two $9 \mathrm{~h}$ stages, rather than using a single $18 \mathrm{~h}$ period, improved recoveries, especially for some of the IM compounds and daughter products. For NTO, PA, 4-NP, 2,4-DNP, and DNAN, higher recoveries were observed when $\mathrm{MeOH}$ was the extraction solvent, while higher recoveries were observed for 2-NP and NQ with ACN. Interestingly, HMX and RDX recoveries were consistently poor in $\mathrm{MeOH}$ extractions, while with $\mathrm{ACN}$, these two legacy compounds were recovered at near $100 \%$. Since the majority of IM compounds and daughter products were recovered at higher rates by $\mathrm{MeOH}$ than $\mathrm{ACN}$, and since a multi-stage ultrasonication procedure was shown to increase recovery rates overall, further experiments were modified from the $2 \times 9 \mathrm{~h} \mathrm{MeOH}$ option, and were designed mainly to improve recoveries of NQ, NTO, HMX, and RDX.

Several two- and three-stage ultrasonication sequences using various combinations of extraction solvents (including $\mathrm{MeOH}, 5 \mathrm{O} / 5 \mathrm{O}$ $\mathrm{MeOH} /$ water, and water) were tested, with a summary of the results shown in Table 13. Options A-D were three-stage sequences, where stage one and two were carried out during extraction Day 1 and stage three was carried out overnight from Day 1 into Day 2. Options E-J were two-stage sequences, where stage one of option $\mathrm{E}-\mathrm{G}$ was carried out during extraction Day 1, and stage two was carried out overnight from Day 1 into Day 2 like with options A-D. Meanwhile, for options H-J, extraction stage one was carried out on Day 1, and stage two was carried out on Day 2, with overnight storage at $4^{\circ} \mathrm{C}$ in the absence of light. Several multistage ultrasonication sequences resulted in recovery rates for all compounds within the DoD QSM Ver5.2 accepted range (64\%-135\%) for soils analyzed by USEPA Method 8330B, including options A, B, F, G, I, and J. Each of these options employed a combination of $\mathrm{MeOH}$ and water extraction solvents. Only options $\mathrm{E}$ and $\mathrm{H}$, which consisted of sequential (6 $\mathrm{h}-14 \mathrm{~h}$ or $8 \mathrm{~h}-8 \mathrm{~h}$, respectively) $\mathrm{MeOH}$ extractions, resulted in low recoveries of NQ, NTO, HMX, and RDX, as expected on the basis of previous results (Table 12). Of the six multistage options that showed acceptable recoveries for all compounds, option $\mathrm{F}$ or $\mathrm{G}$ was preferred so as to simplify the method and to enable users to perform the procedure within the time constraints of a normal workday. 
Table 12. Recoveries (\%) from spiked ASTM fat clay using either MeOH or ACN to perform SE for either $1 \times 18 \mathrm{~h}$ or $2 \times 9 \mathrm{~h}$ ultrasonication periods.

\begin{tabular}{|c|c|c|c|c|}
\hline \multirow[b]{2}{*}{ Compound } & \multicolumn{4}{|c|}{ Recoveries (\%) } \\
\hline & $18 \mathrm{~h} \mathrm{MeOH}$ & $2 \times 9 \mathrm{~h} \mathrm{MeOH}$ & $18 \mathrm{~h} \mathrm{ACN}$ & $2 \times 9 \mathrm{~h} \mathrm{ACN}$ \\
\hline$N Q$ & $30+$ & $41 \dagger$ & $36+$ & $50+$ \\
\hline NTO $(210 \mathrm{~nm})$ & $22 \uparrow$ & $58+$ & $15+$ & $30+$ \\
\hline HMX & $15 \dagger$ & $37 t$ & 84 & 103 \\
\hline RDX & $15 \dagger$ & $35+$ & 78 & 95 \\
\hline$P A(210 \mathrm{~nm})$ & $75^{\star}$ & 92 & $64^{*}$ & 76 \\
\hline 4-NP & 84 & 104 & 82 & 93 \\
\hline 1,3,5-TNB & 87 & 108 & 90 & 110 \\
\hline $2,4-D N P$ & $48+$ & $75^{\star}$ & $24 \dagger$ & $21 \dagger$ \\
\hline 1,2-DNB (surr.) & 81 & 103 & 82 & 101 \\
\hline 1,3-DNB & 86 & 106 & 76 & 97 \\
\hline $2-N P$ & 45 & $67^{*}$ & $64^{*}$ & 80 \\
\hline NB & 84 & 105 & 78 & 97 \\
\hline 3,5-DNA (254 nm) & 93 & 113 & 87 & 104 \\
\hline DNAN & 84 & 105 & $75^{*}$ & 89 \\
\hline Tetryl & 82 & 102 & $68 *$ & 98 \\
\hline$N G$ & 85 & 106 & $45+$ & 121 \\
\hline 2,4,6-TNT & 87 & 107 & 86 & 119 \\
\hline 4-Am-2,6-DNT & 88 & 111 & 109 & $165+$ \\
\hline 2-Am-4,6-DNT & 88 & 114 & 120 & $172 \dagger$ \\
\hline 2,6-DNT & 84 & 99 & 86 & 114 \\
\hline 2,4-DNT & 90 & 116 & 92 & 108 \\
\hline 2-NT & 92 & 112 & 79 & 114 \\
\hline 4-NT & 88 & 107 & 90 & 115 \\
\hline 3-NT & 88 & 110 & 89 & $128 *$ \\
\hline PETN & 90 & 111 & 87 & 118 \\
\hline
\end{tabular}

Bold, italicized are IM compounds and degradation products.

Green: $75 \%-125 \%$; light green $(*)$ : $64 \%-74 \%$ or $126 \%-135 \%$; red $(\dagger):<64 \%$ or $>135 \%$

(DoD QSM Ver5.2 for Solids-lowest LCL: 4-Am-2,6-DNT, 64\%; highest UCL: Tetryl, 135\%) 
Table 13. Recoveries (\%) from spiked ASTM fat clay using several multi-stage SE sequences with ultrasonication for either $3 \mathrm{~h}-3 \mathrm{~h}-4 \mathrm{~h}, 6 \mathrm{~h}-14 \mathrm{~h}$, or $8 \mathrm{~h}-8 \mathrm{~h}$ with various solvent

\begin{tabular}{|c|c|c|c|c|c|c|c|c|c|c|}
\hline \multirow[b]{3}{*}{ Compound } & \multicolumn{10}{|c|}{ Recoveries (\%) } \\
\hline & \multicolumn{4}{|c|}{$3 h-3 h-14 h$} & \multicolumn{3}{|l|}{$6 \mathrm{~h}-14 \mathrm{~h}$} & \multicolumn{3}{|l|}{$8 h-8 h$} \\
\hline & \begin{tabular}{|l|} 
A \\
1. $\mathrm{MeOH}$ \\
2. $\mathrm{MeOH}$ \\
3. $\mathrm{H}_{2} \mathrm{O}$
\end{tabular} & \begin{tabular}{|l|} 
B \\
1. $\mathrm{MeO}$ \\
2. $\mathrm{H}_{2} \mathrm{O}$ \\
3. $\mathrm{H}_{2} \mathrm{O}$
\end{tabular} & $\begin{array}{l}\text { C } \\
\text { 1. } \mathrm{MeOH} \\
\text { 2. } \mathrm{MeOH} \\
\text { 3. } \mathrm{MeOH} / \mathrm{H}_{2} \mathrm{O}\end{array}$ & $\begin{array}{l}\text { D } \\
\text { 1. } \mathrm{MeOH} \\
\text { 2. } \mathrm{MeOH} / \mathrm{H}_{2} \mathrm{O} \\
\text { 3. } \mathrm{H}_{2} \mathrm{O}\end{array}$ & $\begin{array}{l}\mathrm{E} \\
\text { 1. } \mathrm{MeOH} \\
\text { 2. } \mathrm{MeOH}\end{array}$ & $\begin{array}{l}\mathrm{F} \\
\text { 1. } \mathrm{MeOH} \\
2 . \\
\mathrm{MeOH} / \mathrm{H}_{2} \mathrm{O}\end{array}$ & $\begin{array}{l}\mathrm{G} \\
\text { 1. } \mathrm{MeOH} \\
\text { 2. } \mathrm{H}_{2} \mathrm{O}\end{array}$ & $\begin{array}{l}\mathrm{H} \\
\text { 1. } \mathrm{MeOH} \\
\text { 2. } \mathrm{MeO}\end{array}$ & \begin{tabular}{|l|} 
I. $\mathrm{MeOH}$ \\
2. $\mathrm{H}_{2} \mathrm{O}$
\end{tabular} & $\begin{array}{l}\mathrm{J} \\
\text { 1. } \mathrm{MeOH} \\
\text { 2. } \mathrm{MeOH} / \mathrm{H}_{2} \mathrm{O}\end{array}$ \\
\hline$N Q$ & $69^{*}$ & 88 & $54 \dagger$ & $69^{*}$ & $53+$ & $69^{*}$ & 79 & $52 \dagger$ & $74^{*}$ & $66^{*}$ \\
\hline NTO $(210 \mathrm{~nm})$ & 77 & 94 & 91 & 107 & $37 \dagger$ & 97 & 86 & $36 \dagger$ & 81 & 82 \\
\hline HMX & $65 *$ & 92 & $68 *$ & 92 & $31 \dagger$ & $72 *$ & $71 *$ & $32 \dagger$ & $69 *$ & $67 *$ \\
\hline RDX & $69 *$ & 99 & $72 *$ & 96 & $32 \dagger$ & 76 & 77 & $33 t$ & $74 *$ & $71^{*}$ \\
\hline$P A(210 n m)$ & 104 & $126^{*}$ & 107 & $125^{*}$ & 116 & 121 & 123 & 110 & 114 & 115 \\
\hline 4-NP & 103 & 119 & 107 & $125^{*}$ & 120 & 122 & 124 & 116 & 119 & 119 \\
\hline $1,3,5-\mathrm{TNB}$ & 105 & 110 & 110 & 124 & 125 & 122 & 115 & 121 & 110 & 121 \\
\hline 2,4-DNP & 92 & 116 & 95 & 118 & 81 & 110 & 111 & 79 & 104 & 102 \\
\hline $\begin{array}{r}1,2-\mathrm{DNB} \\
\text { (surrogate) }\end{array}$ & 104 & 117 & 106 & 124 & 120 & 121 & 122 & 115 & 117 & 118 \\
\hline 1,3-DNB & 105 & 120 & 108 & $128^{*}$ & 124 & 125 & 125 & 120 & 121 & 123 \\
\hline $2-N P$ & 77 & 107 & 79 & 109 & $69^{*}$ & 103 & 104 & $69 *$ & 95 & 93 \\
\hline NB & 104 & 116 & 104 & 124 & 119 & 118 & 116 & 117 & 112 & 114 \\
\hline 3,5-DNA $(254 \mathrm{~nm})$ & 99 & 113 & 99 & 116 & 110 & 111 & 112 & 107 & 107 & 108 \\
\hline$D N A N$ & 104 & 115 & 112 & $127^{*}$ & $128^{*}$ & 120 & 121 & 118 & 115 & 120 \\
\hline Tetryl & 102 & 114 & 103 & 123 & 119 & 117 & 117 & 115 & 111 & 119 \\
\hline $\mathrm{NG}$ & 94 & 102 & 86 & 105 & 98 & 99 & 101 & 98 & 97 & 98 \\
\hline 2,4,6-TNT & 99 & 109 & 100 & 119 & 117 & 118 & 113 & 113 & 110 & 114 \\
\hline 4-Am-2,6-DNT & 106 & 119 & 113 & $130 *$ & 122 & 123 & 122 & 119 & 118 & 120 \\
\hline 2-Am-4,6-DNT & 108 & 123 & 116 & $137 \dagger$ & $131 *$ & $132 *$ & $130 *$ & $127 *$ & $126^{*}$ & $133 *$ \\
\hline 2,6-DNT & 110 & 116 & 105 & 124 & 117 & 117 & 124 & $133 *$ & 121 & 117 \\
\hline 2,4-DNT & 104 & 119 & 111 & $128^{*}$ & $126^{*}$ & $126^{*}$ & 123 & 117 & 119 & 124 \\
\hline 2-NT & 105 & 120 & 108 & $127 *$ & $127 *$ & $127 *$ & 125 & 123 & 120 & $126^{*}$ \\
\hline
\end{tabular}




\begin{tabular}{|c|c|c|c|c|c|c|c|c|c|c|}
\hline \multirow[b]{3}{*}{ Compound } & \multicolumn{10}{|c|}{ Recoveries (\%) } \\
\hline & \multicolumn{4}{|c|}{$3 h-3 h-14 h$} & \multicolumn{3}{|l|}{$6 h-14 h$} & \multicolumn{3}{|l|}{$8 h-8 h$} \\
\hline & $\begin{array}{l}\text { A } \\
\text { 1. } \mathrm{MeOH} \\
\text { 2. } \mathrm{MeOH} \\
\text { 3. } \mathrm{H}_{2} \mathrm{O}\end{array}$ & $\begin{array}{l}\text { B } \\
\text { 1. } \mathrm{MeO} \\
\text { 2. } \mathrm{H}_{2} \mathrm{O} \\
\text { 3. } \mathrm{H}_{2} \mathrm{O}\end{array}$ & $\begin{array}{l}\text { C } \\
\text { 1. } \mathrm{MeOH} \\
\text { 2. } \mathrm{MeOH} \\
\text { 3. } \mathrm{MeOH} / \mathrm{H}_{2} \mathrm{O}\end{array}$ & $\begin{array}{l}\text { D } \\
\text { 1. } \mathrm{MeOH} \\
\text { 2. } \mathrm{MeOH} / \mathrm{H}_{2} \mathrm{O} \\
\text { 3. } \mathrm{H}_{2} \mathrm{O}\end{array}$ & $\begin{array}{l}\mathrm{E} \\
\text { 1. } \mathrm{MeOH} \\
\text { 2. } \mathrm{MeOH}\end{array}$ & $\begin{array}{l}\mathrm{F} \\
1 . \mathrm{MeOH} \\
2 . \\
\mathrm{MeOH} / \mathrm{H}_{2} \mathrm{O}\end{array}$ & $\begin{array}{l}\mathrm{G} \\
\text { 1. } \mathrm{MeOH} \\
\text { 2. } \mathrm{H}_{2} \mathrm{O}\end{array}$ & $\begin{array}{l}\mathrm{H} \\
\text { 1. } \mathrm{MeOH} \\
\text { 2. } \mathrm{MeO}\end{array}$ & \begin{tabular}{|l|} 
I. $\mathrm{MeOH}$ \\
2. $\mathrm{H}_{2} \mathrm{O}$
\end{tabular} & $\begin{array}{l}\mathrm{J} \\
\text { 1. } \mathrm{MeOH} \\
\text { 2. } \mathrm{MeOH} / \mathrm{H}_{2} \mathrm{O}\end{array}$ \\
\hline 4-NT & 105 & 116 & 108 & 124 & $126^{*}$ & $127 *$ & 124 & 122 & 119 & 125 \\
\hline 3-NT & 103 & 116 & 110 & $126^{*}$ & 122 & 123 & 121 & 118 & 117 & 118 \\
\hline PETN & 113 & $132 *$ & 109 & $128^{*}$ & $130 *$ & $131 *$ & $135^{*}$ & $125 *$ & $132 *$ & $135 *$ \\
\hline
\end{tabular}

Green: $75 \%-125 \%$; light green (*): $64 \%-74 \%$ or $126 \%-135 \%$; red $(+):<64 \%$ or $>135 \%$

Green: $75 \%-125 \%$; light green $\left(^{\star}\right): 64 \%-74 \%$ or $126 \%-135 \%$; red $(\dagger):<64 \%$ or $>135 \%$
(DoD QSM Ver5.2 for Solids-lowest LCL: 4-Am-2,6-DNT, 64\%; highest UCL: Tetryl, $135 \%)$ 
Overall, the results shown in Table 13 indicated that water (a more polar solvent than either $\mathrm{ACN}$ or $\mathrm{MeOH}$ ) effectively improved recoveries of NQ, NTO, HMX, and RDX from ASTM fat clay spiked samples and also aided recovery of some other compounds, including 2,4-DNP and 2-NP. While NQ and NTO are highly water soluble and higher recoveries due to extracting with $\mathrm{MeOH} /$ water or water were expected for them, the superior ability of water versus $\mathrm{MeOH}$ to extract $\mathrm{HMX}$ and RDX was not predicted. However, this unexpected result may be because of the observed ability of the water physically to disperse the soil much better than the $\mathrm{MeOH}$, possibly preventing the entrapment of the hydrophobic compounds and resulting in higher observed recoveries.

Because of the unexpected nature of the results when using water as the extraction solvent or cosolvent with $\mathrm{MeOH}$, a similar experiment was carried out to confirm the effects (data not shown). In addition, a comparison of $18 \mathrm{~h}$ ultrasonic extractions using either $\mathrm{ACN}, \mathrm{MeOH}$, or $50 / 50 \mathrm{MeOH} /$ water in several different soil types was performed. Six soils with varying physicochemical characteristics were used, described in Table 14, including five field soils (Aberdeen, Jefferson, Memphis, Riley, and Yuma), and the ASTM fat clay used previously. Soil classification is provided, including gravel, sand, and fines percentages. Chemical properties include $\mathrm{pH}$, cation-exchange capacity (CEC), anion-exchange capacity (AEC), total organic carbon (TOC), and percent moisture. The results shown in Table 15 indicated that extraction of the compounds of interest depended on compound chemical properties and soil characteristics and reinforced previous results that showed that extraction using any single solvent or cosolvent mixture would not be sufficient to extract the 24 compounds (and 1,2-DNB surrogate) from any of the six tested soils. (For the ASTM soil, a water-only option was also tested, with mixed results.)

Because differences were observed for different soil types, further SE method development trials were carried out using all six soils. Using the results from the ASTM fat clay trials (Table 13), two two-stage and two three-stage sequential ultrasonication options were tested (Table 16). All four options were successful for each soil type. Only three outliers occurred, for the Yuma sand using option $\mathrm{C}(3 \mathrm{~h} \mathrm{MeOH}-3 \mathrm{~h}$ water-14 $\mathrm{h}$ water), which were $1 \%-3 \%$ higher than the accepted $135 \%$ (DoD QSM Ver5.2). Thus, this subsequent round of trials confirmed that including 
water as an extraction solvent resulted in improved recoveries for NQ, NTO, HMX, and RDX across a broad range of soil types.

Overall, it was shown that a two-stage SE procedure including water as an extraction solvent (Table 16, option A and B) was necessary and sufficient to result in recovery of all compounds of interest (and two surrogates) within current accepted limits (64\%-135\%) for all soils tested. Results for further tests carried out using option A (for the compounds of interest and two surrogates) appear in sections 3.9 and 3.10. Option A was selected over option B so that both stages in the extraction procedure would include organic extraction solvent $(\mathrm{MeOH})$, which minimized deviation from current USEPA Method $8330 \mathrm{~B}$ procedures. A three-stage extraction sequence proved unnecessary but may be employed, if desired. For cases in which NQ, NTO, HMX, and RDX are known to be absent or are not of interest in soils similar to those tested, an extraction procedure that includes water as an extraction solvent may not be necessary. In such cases, a one-step ultrasonication may be sufficient, and a two-step procedure may not enhance recovery at a statistically significant or costeffective rate. 
Table 14. Characteristic properties for six soils used in SE method development and testing for soils.

\begin{tabular}{|c|c|c|c|c|c|c|c|c|c|c|c|}
\hline Name & Collection Site & Region & Classification & Gravel (\%) & Sand (\%) & Fines (\%) & $\mathrm{pH}$ & $\begin{array}{l}\text { CEC (meq } \\
\mathrm{Na} / 100 \mathrm{~g})\end{array}$ & $\begin{array}{l}\text { AEC (meq } \\
\text { S / 100g) }\end{array}$ & $\begin{array}{c}\text { TOC } \\
(\mathrm{mg} / \mathrm{kg})\end{array}$ & Moisture (\%) \\
\hline Aberdeen & $\begin{array}{c}\text { Aberdeen Proving } \\
\text { Ground (Aberdeen, MD) }\end{array}$ & Mid Atlantic, Southeast & Clay (CL) with sand & 2.9 & 25.4 & 71.7 & 7.12 & 20.6 & 51.2 & 6,700 & 2.1 \\
\hline Jefferson & $\begin{array}{c}\text { Jefferson Proving } \\
\text { Ground (Madison, IN) }\end{array}$ & Great Lakes, Midwest & Clay (CL) with sand & 0.0 & 19.7 & 80.3 & 4.62 & 26.2 & 60.9 & 1,400 & 2.1 \\
\hline Memphis & Memphis, TN & Mid-South & Silt (ML) & 0.0 & 0.5 & 99.5 & 7.56 & 11.8 & 45.3 & 610 & 1.1 \\
\hline Riley & Ft. Riley (Riley, KS) & Central Plains, Midwest & Clay; trace of sand & 0.0 & 3.3 & 96.7 & 5.96 & 32.9 & 53.0 & 15,000 & 1.4 \\
\hline Yuma & $\begin{array}{c}\text { Yuma Proving Ground } \\
\text { (Yuma, AZ) }\end{array}$ & Pacific, Southwest & Sand with gravel & 35 & 53.2 & 11.8 & 6.98 & 14.7 & 47.9 & $N D *$ & 1.6 \\
\hline ASTM Fat Clay (CH-1) & \multicolumn{2}{|c|}{ (ASTM-ISR Reference Soils Program) } & Clay $(\mathrm{CH})$ & 0.0 & 0.7 & 99.3 & 7.45 & 24.5 & 24.4 & 3,600 & 5.9 \\
\hline
\end{tabular}

*ND: not detected (Reporting limit: $250 \mathrm{mg} / \mathrm{kg}$ ) 
Table 15. Recoveries (\%) from six laboratory-spiked soils using an $18 \mathrm{~h}$ ultrasonication period with $\mathrm{ACN}, \mathrm{MeOH}, 50 / 50 \mathrm{MeOH} /$ water, or water.

\begin{tabular}{|c|c|c|c|c|c|c|c|c|c|}
\hline \multirow[b]{3}{*}{ Compound } & \multicolumn{9}{|c|}{ Recoveries (\%) } \\
\hline & \multicolumn{3}{|c|}{ Aberdeen } & \multicolumn{3}{|c|}{ Jefferson } & \multicolumn{3}{|c|}{ Memphis } \\
\hline & $\mathrm{ACN}$ & $\mathrm{MeOH}$ & $\mathrm{MeOH} / \mathrm{H}_{2} \mathrm{O}$ & ACN & $\mathrm{MeOH}$ & $\mathrm{MeOH} / \mathrm{H}_{2} \mathrm{O}$ & $\mathrm{ACN}$ & $\mathrm{MeOH}$ & $\mathrm{MeOH} / \mathrm{H}_{2} \mathrm{O}$ \\
\hline$N Q$ & $67^{*}$ & $72^{\star}$ & 108 & $67^{*}$ & 81 & 106 & $38+$ & 91 & 123 \\
\hline NTO $(210 \mathrm{~nm})$ & 22 & 14 & 88 & 22 & 8 & 108 & 24 & 50 & 101 \\
\hline $\mathrm{HMX}$ & 109 & 40 & 96 & 112 & 39 & 96 & 107 & $42 \dagger$ & 87 \\
\hline RDX & 110 & 45 & 108 & 103 & 49 & 103 & 105 & 48 & 97 \\
\hline$P A(210 \mathrm{~nm})$ & 58 & 98 & 113 & 11 & 100 & 120 & 84 & 108 & $128^{*}$ \\
\hline $4-N P$ & 98 & 99 & 105 & 100 & 109 & 97 & 94 & 103 & 104 \\
\hline 1,3,5-TNB & 109 & 99 & 85 & 106 & 104 & 84 & 104 & 100 & 55 \\
\hline 2,4-DNP & 21 & 82 & 105 & 60 & 51 & 105 & 15 & 85 & 103 \\
\hline 1,2-DNB (surr.) & 95 & 87 & 87 & 92 & 96 & 84 & 85 & 89 & 91 \\
\hline 1,3-DNB & 92 & 87 & 88 & 92 & 98 & 85 & 91 & 90 & 89 \\
\hline $2-N P$ & 43 & 33 & 45 & 33 & 44 & 6 & 11 & 15 & 38 \\
\hline NB & 108 & 105 & 100 & 97 & 103 & 99 & 105 & 104 & 92 \\
\hline $\begin{array}{c}\text { 3,5-DNA (254 } \\
\mathrm{nm})\end{array}$ & 15 & 11 & 15 & 20 & 25 & ND & 63 & 4 & 24 \\
\hline$D N A N$ & 102 & 103 & 99 & 103 & 108 & 93 & 104 & 98 & 94 \\
\hline Tetryl & 99 & 94 & $72 *$ & 98 & 102 & 31 & 104 & 49 & 97 \\
\hline$N G$ & 97 & 92 & 97 & $64 *$ & 90 & 86 & 83 & 90 & 86 \\
\hline 2,4,6-TNT & 106 & 102 & 102 & 101 & 108 & 115 & 96 & 118 & 88 \\
\hline 4-Am-2,6-DNT & 108 & 108 & 105 & 97 & 102 & 102 & 102 & 106 & 92 \\
\hline 2-Am-4,6-DNT & 111 & 107 & 101 & 100 & 103 & 101 & 109 & 104 & 95 \\
\hline 2,6-DNT & 96 & 88 & 86 & 93 & 89 & 80 & 85 & 88 & 89 \\
\hline 2,4-DNT & 96 & 87 & 117 & 84 & 94 & 83 & 82 & 91 & 86 \\
\hline 2-NT & 51 & 29 & 33 & 43 & 45 & 4 & 16 & 15 & 43 \\
\hline 4-NT & 61 & 56 & 58 & $69 *$ & $71^{*}$ & 24 & 51 & 44 & $67 *$ \\
\hline 3-NT & 58 & 44 & 48 & 54 & 61 & 12 & 20 & 30 & 55 \\
\hline PETN & 112 & 110 & 103 & 106 & 111 & 99 & 97 & 106 & 103 \\
\hline
\end{tabular}

Bold, italicized are IM compounds and degradation products. ND: not detected. Green: $75 \%-125 \%$; light green (*): $64 \%-74 \%$ or $126 \%-135 \%$; red $(\dagger):<64 \%$ or $>135 \%$ (DoD QSM Ver5.2 for Solids-lowest LCL: 4-Am-2,6-DNT, 64\%; highest UCL: Tetryl, 135\%) 
Table 15 (continued).

\begin{tabular}{|c|c|c|c|c|c|c|c|c|c|c|}
\hline \multirow[b]{3}{*}{ Compound } & \multicolumn{10}{|c|}{ Recoveries (\%) } \\
\hline & \multicolumn{3}{|c|}{ Riley } & \multicolumn{3}{|c|}{ Yuma } & \multicolumn{4}{|c|}{ ASTM Fat Clay } \\
\hline & $\mathrm{ACN}$ & $\mathrm{MeOH}$ & $\begin{array}{c}\mathrm{MeOH} / \\
\mathrm{H}_{2} \mathrm{O}\end{array}$ & $\mathrm{ACN}$ & $\mathrm{MeOH}$ & $\begin{array}{c}\mathrm{MeOH} / \\
\mathrm{H}_{2} \mathrm{O}\end{array}$ & $\mathrm{ACN}$ & $\mathrm{MeOH}$ & $\begin{array}{c}\mathrm{MeOH} / \\
\mathrm{H}_{2} \mathrm{O}\end{array}$ & $\mathrm{H}_{2} \mathrm{O}$ \\
\hline$N Q$ & $35+$ & 65 & 100 & $52+$ & 79 & 84 & $62+$ & 66 & 103 & 91 \\
\hline NTO $(210 \mathrm{~nm})$ & $23+$ & $21 \dagger$ & 64 & $24 \dagger$ & $43+$ & 95 & $8+$ & $17 \dagger$ & 107 & 105 \\
\hline HMX & 94 & $26+$ & 79 & 105 & $34 \dagger$ & 84 & 92 & $19+$ & 75 & 70 \\
\hline RDX & 97 & $32 \dagger$ & 88 & 99 & $33+$ & 94 & 92 & $23+$ & 86 & 99 \\
\hline$P A(210 \mathrm{~nm})$ & $38+$ & 99 & 108 & 92 & 106 & 130 & 96 & 109 & 122 & 129 \\
\hline 4-NP & 86 & 101 & 98 & 99 & 104 & 97 & 97 & 123 & 114 & 120 \\
\hline 1,3,5-TNB & 109 & 103 & $55+$ & 99 & 105 & 86 & 93 & 121 & 84 & $37 t$ \\
\hline 2,4-DNP & $42+$ & $51 \dagger$ & 99 & $23+$ & $56+$ & 97 & $32 \uparrow$ & $51 \dagger$ & 92 & 96 \\
\hline 1,2-DNB (surr.) & 94 & 93 & 93 & 94 & 87 & 84 & 95 & 113 & 92 & 101 \\
\hline 1,3-DNB & 97 & 97 & 89 & 91 & 90 & 83 & 91 & 117 & 96 & 87 \\
\hline $2-N P$ & $56+$ & 65 & 69 & $36+$ & $23+$ & $37+$ & $59+$ & $53+$ & $N D+$ & 77 \\
\hline NB & 85 & 86 & 76 & 101 & 105 & 95 & 92 & 117 & 101 & 71 \\
\hline 3,5-DNA (254 nm) & $57 \dagger$ & $54+$ & $59+$ & $11 \dagger$ & $8+$ & $9+$ & $45 t$ & $52 \dagger$ & $\mathrm{ND}+$ & $33+$ \\
\hline DNAN & 97 & 101 & 86 & 99 & 101 & 94 & 94 & 113 & 96 & 55 \\
\hline Tetryl & 97 & 93 & 79 & 107 & 70 & $31 \dagger$ & $17 \dagger$ & 65 & 66 & $35 \dagger$ \\
\hline$N G$ & 84 & 100 & 92 & 101 & 95 & 85 & 104 & 124 & 95 & 109 \\
\hline 2,4,6-TNT & 95 & 105 & 84 & 95 & 116 & 112 & 109 & $138+$ & 106 & 70 \\
\hline 4-Am-2,6-DNT & 80 & 85 & 78 & 103 & 106 & 113 & $18+$ & 121 & 110 & $6+$ \\
\hline 2-Am-4,6-DNT & 91 & 93 & 81 & 103 & 104 & 95 & 93 & 117 & 101 & 68 \\
\hline 2,6-DNT & 87 & 106 & 97 & 71 & 91 & 84 & 87 & $138+$ & 81 & 107 \\
\hline 2,4-DNT & 96 & 92 & 84 & 89 & 90 & 84 & 95 & 118 & 94 & 69 \\
\hline 2-NT & 73 & 69 & 68 & $35+$ & $20 \dagger$ & $20+$ & $55+$ & 64 & $\mathrm{ND}+$ & $43+$ \\
\hline 4-NT & 94 & 85 & 78 & $62 \dagger$ & $45 \dagger$ & $44 \dagger$ & $62+$ & 80 & $\mathrm{ND}+$ & $58+$ \\
\hline 3-NT & 76 & 79 & 74 & $38+$ & $32 \dagger$ & $32 \dagger$ & 67 & 71 & $\mathrm{ND}+$ & $50 \dagger$ \\
\hline PETN & 97 & 108 & 99 & 100 & 105 & 95 & 100 & 122 & 102 & $31 \dagger$ \\
\hline
\end{tabular}

Bold, italicized are IM compounds and degradation products. ND: not detected.

Green: $75 \%-125 \%$; light green (*): $64 \%-74 \%$ or $126 \%-135 \%$; red $(\dagger):<64 \%$ or $>135 \%$

(DoD QSM Ver5.2 for Solids-lowest LCL: 4-Am-2,6-DNT, 64\%; highest UCL: Tetryl, 135\%) 
Table 16. Recoveries (\%) from six laboratory-spiked soils using four different two- or three-stage ultrasonication sequences. (A) $6 \mathrm{~h}$ MeOH-14-h MeOH/water; (B) $6 \mathrm{~h}$ MeOH-14 h water; (C) $3 \mathrm{~h} \mathrm{MeOH}-3 \mathrm{~h}$ water-14 $\mathrm{h}$ water; (D) $3 \mathrm{~h} \mathrm{MeOH}-3 \mathrm{~h} \mathrm{MeOH}-14 \mathrm{~h}$ water. (AVG = average; SD = standard deviation)

\begin{tabular}{|c|c|c|c|c|c|c|c|c|c|c|c|c|c|c|c|c|}
\hline \multirow[b]{4}{*}{ Compound } & \multicolumn{16}{|c|}{ Recoveries (\%) } \\
\hline & \multicolumn{8}{|c|}{ Aberdeen } & \multicolumn{8}{|c|}{ Jefferson } \\
\hline & \multicolumn{2}{|l|}{ A } & \multicolumn{2}{|l|}{ B } & \multicolumn{2}{|l|}{ C } & \multicolumn{2}{|l|}{ D } & \multicolumn{2}{|l|}{ A } & \multicolumn{2}{|l|}{ B } & \multicolumn{2}{|l|}{ C } & \multicolumn{2}{|l|}{ D } \\
\hline & $\begin{array}{l}\text { AVG } \\
(n=3)\end{array}$ & SD & $\begin{array}{l}\text { AVG } \\
(n=3)\end{array}$ & SD & $\begin{array}{l}\text { AVG } \\
(n=3)\end{array}$ & SD & $\begin{array}{l}\text { AVG } \\
(n=3)\end{array}$ & SD & $\begin{array}{l}\text { AVG } \\
(n=3)\end{array}$ & SD & $\begin{array}{l}\text { AVG } \\
(n=3)\end{array}$ & SD & $\begin{array}{l}\text { AVG } \\
(n=3)\end{array}$ & SD & $\begin{array}{l}\text { AVG } \\
(n=3)\end{array}$ & SD \\
\hline$N Q$ & 98 & 10 & 102 & 5 & 120 & 3 & 117 & 8 & 106 & 10 & 104 & 4 & 119 & 1 & 109 & 6 \\
\hline NTO $(210 \mathrm{~nm})$ & 81 & 10 & 80 & 3 & 96 & 2 & 86 & 2 & 83 & 8 & 88 & 1 & 113 & 2 & 96 & 1 \\
\hline HMX & 87 & 5 & 80 & 2 & 107 & 1 & 91 & 3 & 83 & 3 & 78 & 2 & 100 & 3 & 87 & 3 \\
\hline RDX & 93 & 6 & 88 & 4 & 113 & 2 & 103 & 1 & 94 & 3 & 89 & 2 & 110 & 2 & 99 & 1 \\
\hline$P A(210 n m)$ & 105 & 7 & 106 & 8 & 120 & 8 & 117 & 4 & 109 & 5 & 101 & 4 & 114 & 8 & 115 & 9 \\
\hline $4-N P$ & 115 & 8 & 110 & 5 & 123 & 7 & $126^{*}$ & 2 & 121 & 4 & 113 & 5 & 122 & 6 & 124 & 7 \\
\hline $1,3,5-\mathrm{TNB}$ & 112 & 8 & 100 & 2 & 114 & 6 & 120 & 6 & 111 & 6 & 96 & 3 & $132 *$ & 3 & 119 & 2 \\
\hline $2,4-D N P$ & 104 & 7 & 99 & $<1$ & 120 & 3 & 114 & 4 & 95 & 4 & 88 & 3 & 107 & 6 & 96 & 2 \\
\hline 1,2-DNB (surrogate) & 123 & 6 & 118 & 4 & $125^{*}$ & 6 & $128^{*}$ & 1 & 121 & 10 & 117 & 6 & $127^{*}$ & 3 & 123 & 8 \\
\hline 1,3-DNB & 119 & 9 & 112 & 4 & $125^{*}$ & 8 & $128 *$ & 4 & 123 & 5 & 115 & 4 & 124 & 3 & $126^{*}$ & 3 \\
\hline $2-N P$ & 103 & 11 & 96 & 3 & 108 & 6 & 107 & 3 & 100 & 4 & 95 & 3 & 105 & 2 & 105 & 1 \\
\hline NB & 119 & 9 & 111 & 4 & $125^{*}$ & 8 & $128^{*}$ & 4 & 120 & 6 & 110 & 3 & 119 & 3 & 122 & 3 \\
\hline 3,5-DNA $(254 \mathrm{~nm})$ & 89 & 7 & 86 & 4 & 92 & 6 & 96 & 3 & 101 & 6 & 96 & 3 & 101 & 3 & 102 & 5 \\
\hline DNAN & 117 & 10 & 111 & 5 & 123 & 10 & $126^{*}$ & 6 & 121 & 6 & 109 & 2 & 115 & 3 & 124 & 3 \\
\hline Tetryl & 103 & 10 & 99 & 7 & 113 & 4 & 115 & 3 & 115 & 6 & 109 & 7 & 120 & 5 & 121 & 7 \\
\hline $\mathrm{NG}$ & 113 & 16 & 105 & 10 & 115 & 3 & 119 & 10 & 107 & 11 & 105 & 12 & 112 & 10 & 115 & 14 \\
\hline $2,4,6-\mathrm{TNT}$ & 116 & 8 & 106 & 6 & 120 & 7 & 123 & 5 & 117 & 1 & 105 & 3 & 112 & 3 & 120 & 5 \\
\hline 4-Am-2,6-DNT & 124 & 10 & 112 & 4 & $126^{*}$ & 9 & $129 *$ & 3 & 120 & 6 & 112 & 3 & 121 & 3 & 123 & 2 \\
\hline 2-Am-4,6-DNT & 120 & 9 & 111 & 4 & $125^{*}$ & 8 & $128^{*}$ & 3 & 123 & 5 & 114 & 3 & 123 & 3 & $126^{*}$ & 3 \\
\hline 2,6-DNT & 116 & 5 & 107 & 4 & 118 & 11 & 124 & 6 & 120 & 4 & 112 & 3 & 119 & 3 & 119 & 3 \\
\hline $2,4-\mathrm{DNT}$ & 118 & 6 & 110 & 4 & $125^{*}$ & 9 & $126^{*}$ & 6 & 123 & 8 & 111 & 6 & 117 & 7 & 124 & 6 \\
\hline 2-NT & 103 & 7 & 96 & 1 & 103 & 6 & 107 & 4 & 108 & 9 & 101 & 3 & 108 & 4 & 111 & 4 \\
\hline 4-NT & 110 & 6 & 98 & 5 & 110 & 9 & 118 & 5 & 115 & 10 & 106 & 2 & 113 & 4 & 114 & 5 \\
\hline $3-\mathrm{NT}$ & 103 & 7 & 98 & 3 & 107 & 6 & 112 & 4 & 110 & 7 & 103 & 4 & 110 & 5 & 112 & 5 \\
\hline
\end{tabular}




\begin{tabular}{|c|c|c|c|c|c|c|c|c|c|c|c|c|c|c|c|c|}
\hline \multirow[b]{4}{*}{ Compound } & \multicolumn{16}{|c|}{ Recoveries (\%) } \\
\hline & \multicolumn{8}{|c|}{ Aberdeen } & \multicolumn{8}{|c|}{ Jefferson } \\
\hline & \multicolumn{2}{|l|}{$A$} & \multicolumn{2}{|l|}{ B } & \multicolumn{2}{|l|}{$\mathrm{C}$} & \multicolumn{2}{|l|}{ D } & \multicolumn{2}{|l|}{$A$} & \multicolumn{2}{|l|}{ B } & \multicolumn{2}{|l|}{ C } & \multicolumn{2}{|l|}{ D } \\
\hline & $\begin{array}{l}\text { AVG } \\
(n=3)\end{array}$ & SD & $\begin{array}{l}\text { AVG } \\
(n=3)\end{array}$ & SD & $\begin{array}{l}\text { AVG } \\
(n=3)\end{array}$ & SD & $\begin{array}{l}\text { AVG } \\
(n=3)\end{array}$ & SD & $\begin{array}{l}\text { AVG } \\
(n=3)\end{array}$ & SD & $\begin{array}{l}\text { AVG } \\
(n=3)\end{array}$ & SD & $\begin{array}{l}\text { AVG } \\
(n=3)\end{array}$ & SD & $\begin{array}{l}\text { AVG } \\
(n=3)\end{array}$ & SD \\
\hline PETN & 114 & 8 & 109 & 3 & 124 & 8 & 123 & 3 & 121 & 8 & 114 & 3 & $125^{*}$ & 4 & 124 & 5 \\
\hline
\end{tabular}

Bold, italicized are IM compounds and degradation products. ND: not detected.

Green: $75 \%-125 \%$; light green (*): $64 \%-74 \%$ or $126 \%-135 \%$; red (†): $<64 \%$ or $>135 \%$

Table 16 (continued). (AVG = average; SD = standard deviation)

\begin{tabular}{|c|c|c|c|c|c|c|c|c|c|c|c|c|c|c|c|c|}
\hline \multirow[b]{4}{*}{ Compound } & \multicolumn{16}{|c|}{ Recoveries (\%) } \\
\hline & \multicolumn{8}{|c|}{ Memphis } & \multicolumn{8}{|l|}{ Riley } \\
\hline & \multicolumn{2}{|l|}{ A } & \multicolumn{2}{|l|}{ B } & \multicolumn{2}{|l|}{$\mathrm{C}$} & \multicolumn{2}{|l|}{$\mathrm{D}$} & \multicolumn{2}{|l|}{ A } & \multicolumn{2}{|l|}{ B } & \multicolumn{2}{|l|}{$\mathrm{C}$} & \multicolumn{2}{|l|}{ D } \\
\hline & $\begin{array}{l}\text { AVG } \\
(n=3)\end{array}$ & SD & $\begin{array}{l}\text { AVG } \\
(n=3)\end{array}$ & SD & $\begin{array}{l}\text { AVG } \\
(n=3)\end{array}$ & SD & $\begin{array}{l}\text { AVG } \\
(n=3)\end{array}$ & SD & $\begin{array}{l}\text { AVG } \\
(n=3)\end{array}$ & SD & $\begin{array}{l}\text { AVG } \\
(n=3)\end{array}$ & SD & $\begin{array}{l}\text { AVG } \\
(n=3)\end{array}$ & SD & $\begin{array}{l}\text { AVG } \\
(n=3)\end{array}$ & SD \\
\hline$N Q$ & 107 & 9 & 111 & 1 & 118 & 9 & 115 & 9 & 90 & 6 & 98 & 9 & 111 & 2 & 109 & 5 \\
\hline NTO $(210 \mathrm{~nm})$ & 115 & 15 & 106 & 2 & $125^{*}$ & 2 & 119 & 2 & 100 & 8 & 112 & 3 & $128^{*}$ & 2 & 119 & 4 \\
\hline HMX & 98 & 7 & 90 & 1 & 109 & 3 & 103 & 1 & $67 *$ & 2 & $66^{*}$ & 4 & 84 & 2 & $72 *$ & 3 \\
\hline RDX & 99 & 4 & 94 & $<1$ & 114 & 3 & 106 & 2 & 81 & 1 & 78 & 1 & 101 & 3 & 88 & 1 \\
\hline$P A(210 n m)$ & 121 & 6 & 111 & 5 & $126^{*}$ & 7 & 121 & 2 & 111 & 5 & 103 & 4 & 124 & 3 & 124 & 2 \\
\hline 4-NP & 120 & 4 & 112 & 4 & $126^{*}$ & 5 & 123 & 2 & 115 & 4 & 103 & 3 & 118 & 5 & 120 & $<1$ \\
\hline $1,3,5-\mathrm{TNB}$ & 122 & 4 & 108 & $<1$ & 121 & 4 & $125^{*}$ & 4 & 113 & 4 & 96 & 1 & 104 & 2 & 120 & $<1$ \\
\hline 2,4-DNP & 117 & 7 & 106 & 2 & 123 & 6 & 118 & 1 & 95 & 4 & 89 & 3 & 108 & 1 & 97 & 3 \\
\hline 1,2-DNB (surrogate) & 121 & 7 & 118 & 6 & $126^{*}$ & 6 & $127 *$ & 4 & 121 & 5 & 111 & 8 & $126^{*}$ & 5 & 124 & 4 \\
\hline 1,3-DNB & 123 & 3 & 115 & 2 & $127 *$ & 5 & $126^{*}$ & 3 & 121 & 4 & 108 & 1 & 120 & 4 & $125^{*}$ & 1 \\
\hline $2-N P$ & 91 & 4 & 88 & 1 & 101 & 5 & 96 & 4 & 106 & 4 & 96 & 2 & 105 & 5 & 108 & 2 \\
\hline NB & 124 & 3 & 116 & 1 & $128^{*}$ & 4 & $127 *$ & 3 & 110 & 3 & 93 & $<1$ & 103 & 3 & 111 & $<1$ \\
\hline $3,5-\mathrm{DNA}(254 \mathrm{~nm})$ & 86 & 4 & 81 & 1 & 88 & 6 & 85 & 3 & 108 & 3 & 100 & 2 & 108 & 5 & 112 & 2 \\
\hline$D N A N$ & 122 & 3 & 112 & 2 & $126^{*}$ & 5 & $125^{*}$ & 1 & 119 & 3 & 102 & 1 & 115 & 3 & 123 & 1 \\
\hline Tetryl & 86 & 14 & 82 & 5 & 102 & 4 & 97 & 7 & 112 & 8 & 100 & 4 & 112 & 5 & 117 & 5 \\
\hline
\end{tabular}




\begin{tabular}{|c|c|c|c|c|c|c|c|c|c|c|c|c|c|c|c|c|}
\hline \multirow[b]{4}{*}{ Compound } & \multicolumn{16}{|c|}{ Recoveries (\%) } \\
\hline & \multicolumn{8}{|c|}{ Memphis } & \multicolumn{8}{|l|}{ Riley } \\
\hline & \multicolumn{2}{|l|}{ A } & \multicolumn{2}{|l|}{ B } & \multicolumn{2}{|l|}{ C } & \multicolumn{2}{|l|}{$\mathrm{D}$} & \multicolumn{2}{|l|}{ A } & \multicolumn{2}{|l|}{$\mathrm{B}$} & \multicolumn{2}{|l|}{$C$} & \multicolumn{2}{|l|}{$\mathrm{D}$} \\
\hline & $\begin{array}{l}\text { AVG } \\
(n=3)\end{array}$ & SD & $\begin{array}{l}\text { AVG } \\
(n=3)\end{array}$ & SD & $\begin{array}{l}\text { AVG } \\
(n=3)\end{array}$ & SD & $\begin{array}{l}\text { AVG } \\
(n=3)\end{array}$ & SD & $\begin{array}{l}\text { AVG } \\
(n=3)\end{array}$ & SD & $\begin{array}{l}\text { AVG } \\
(n=3)\end{array}$ & SD & $\begin{array}{l}\text { AVG } \\
(n=3)\end{array}$ & SD & $\begin{array}{l}\text { AVG } \\
(n=3)\end{array}$ & SD \\
\hline NG & 118 & 11 & 113 & 9 & 117 & 13 & 118 & 8 & 111 & 15 & 103 & 11 & 111 & 10 & 118 & 13 \\
\hline 2,4,6-TNT & $130^{*}$ & 1 & 119 & 1 & $129 *$ & 4 & $129^{*}$ & 4 & 117 & 7 & 100 & 2 & 111 & 1 & 122 & 2 \\
\hline 4-Am-2,6-DNT & $127 *$ & 3 & 119 & 1 & $130^{*}$ & 4 & $129^{*}$ & 2 & 109 & 2 & 93 & 1 & 103 & 2 & 110 & 2 \\
\hline 2-Am-4,6-DNT & $125^{*}$ & 3 & 117 & 1 & $128^{*}$ & 4 & $127^{*}$ & 2 & 116 & 3 & 99 & $<1$ & 109 & 3 & 118 & 1 \\
\hline 2,6-DNT & 121 & 4 & 109 & 2 & 124 & 2 & 121 & 4 & 117 & 10 & 100 & 2 & 113 & 6 & $125^{*}$ & 6 \\
\hline 2,4-DNT & 123 & 4 & 115 & 3 & $125^{*}$ & 5 & $126^{*}$ & 2 & 119 & 2 & 106 & 2 & 115 & 6 & $126^{*}$ & 4 \\
\hline 2-NT & 99 & 4 & 91 & 2 & 101 & 5 & 100 & 6 & 112 & 5 & 103 & 1 & 112 & 5 & 119 & 2 \\
\hline 4-NT & 106 & 4 & 99 & 2 & 110 & 2 & 108 & 4 & 114 & 4 & 104 & 2 & 112 & 3 & 121 & 1 \\
\hline 3-NT & 101 & 5 & 93 & $<1$ & 103 & 5 & 101 & 3 & 114 & 3 & 104 & 2 & 112 & 7 & 116 & 4 \\
\hline PETN & 115 & 5 & 109 & 7 & 120 & 7 & 117 & 1 & 121 & 7 & 112 & 3 & 122 & 5 & $125^{*}$ & 5 \\
\hline
\end{tabular}

Bold, italicized are IM compounds and degradation products. ND: not detected.
Green: $75 \%-125 \%$; light green (*): $64 \%-74 \%$ or $126 \%-135 \%$; red (†): $<64 \%$ or $>135 \%$

Green: $75 \%-125 \%$; light green (*): $64 \%-74 \%$ or $126 \%-135 \%$; red (†): $<64 \%$ or $>135 \%$
(DoD QSM Ver5.2 for Solids-lowest LCL: 4-Am-2,6-DNT, 64\%; highest UCL: Tetryl, 135\%)

Table 16 (continued). (AVG = average; SD = standard deviation)

\begin{tabular}{|c|c|c|c|c|c|c|c|c|c|c|c|c|c|c|c|c|}
\hline \multirow[b]{4}{*}{ Compound } & \multicolumn{16}{|c|}{ Recoveries (\%) } \\
\hline & \multicolumn{8}{|l|}{ Yuma } & \multicolumn{8}{|c|}{ ASTM Fat Clay } \\
\hline & \multicolumn{2}{|l|}{ A } & \multicolumn{2}{|l|}{$B$} & \multicolumn{2}{|l|}{$\mathrm{C}$} & \multicolumn{2}{|l|}{ D } & \multicolumn{2}{|c|}{ A } & \multicolumn{2}{|l|}{ B } & \multicolumn{2}{|l|}{$\mathrm{C}$} & \multicolumn{2}{|l|}{$\mathrm{D}$} \\
\hline & $\begin{array}{l}\text { AVG } \\
(n=3)\end{array}$ & SD & $\begin{array}{l}\text { AVG } \\
(n=3)\end{array}$ & SD & $\begin{array}{l}\text { AVG } \\
(n=3)\end{array}$ & SD & $\begin{array}{l}\text { AVG } \\
(n=3)\end{array}$ & SD & $\begin{array}{l}\text { AVG } \\
(n=3)\end{array}$ & SD & $\begin{array}{l}\text { AVG } \\
(n=3)\end{array}$ & SD & $\begin{array}{l}\text { AVG } \\
(n=3)\end{array}$ & SD & $\begin{array}{l}\text { AVG } \\
(n=3)\end{array}$ & SD \\
\hline$N Q$ & 109 & 7 & 106 & 2 & 122 & 4 & 115 & 4 & 101 & 7 & 100 & 5 & 116 & 3 & 113 & 5 \\
\hline NTO (210nm) & 103 & 3 & 88 & 2 & 111 & 5 & 98 & 1 & 90 & 1 & 92 & 2 & 118 & 1 & 101 & 3 \\
\hline HMX & 86 & 4 & 84 & 3 & 105 & 2 & 93 & 2 & $66^{*}$ & 1 & $65^{*}$ & 1 & 92 & 2 & $75^{*}$ & 2 \\
\hline RDX & 92 & 3 & 89 & 2 & 111 & 2 & 98 & $<1$ & $72 *$ & 1 & $72 *$ & 1 & 101 & 1 & 82 & 2 \\
\hline$P A(210 n m)$ & 117 & 6 & 107 & 4 & $127^{*}$ & 6 & 123 & 3 & 106 & 5 & 103 & 7 & 119 & 5 & 120 & 2 \\
\hline $4-N P$ & 119 & 5 & 110 & 3 & $132 *$ & 10 & $125^{*}$ & 2 & 115 & 6 & 112 & 3 & 124 & 1 & $125^{*}$ & 1 \\
\hline
\end{tabular}




\begin{tabular}{|c|c|c|c|c|c|c|c|c|c|c|c|c|c|c|c|c|}
\hline \multirow[b]{4}{*}{ Compound } & \multicolumn{16}{|c|}{ Recoveries (\%) } \\
\hline & \multicolumn{8}{|l|}{ Yuma } & \multicolumn{8}{|c|}{ ASTM Fat Clay } \\
\hline & \multicolumn{2}{|l|}{$A$} & \multicolumn{2}{|l|}{ B } & \multicolumn{2}{|l|}{$\mathrm{C}$} & \multicolumn{2}{|l|}{$\mathrm{D}$} & \multicolumn{2}{|l|}{$A$} & \multicolumn{2}{|l|}{ B } & \multicolumn{2}{|l|}{ C } & \multicolumn{2}{|l|}{ D } \\
\hline & $\begin{array}{l}\text { AVG } \\
(n=3)\end{array}$ & SD & $\begin{array}{l}\text { AVG } \\
(n=3)\end{array}$ & SD & $\begin{array}{l}\text { AVG } \\
(n=3)\end{array}$ & SD & $\begin{array}{l}\text { AVG } \\
(n=3)\end{array}$ & SD & $\begin{array}{l}\text { AVG } \\
(n=3)\end{array}$ & SD & $\begin{array}{l}\text { AVG } \\
(n=3)\end{array}$ & SD & $\begin{array}{l}\text { AVG } \\
(n=3)\end{array}$ & SD & $\begin{array}{l}\text { AVG } \\
(n=3)\end{array}$ & SD \\
\hline $1,3,5-\mathrm{TNB}$ & 120 & 5 & 111 & 1 & $130 *$ & 7 & $127^{*}$ & 2 & 114 & 4 & 103 & 1 & 110 & 1 & 124 & 4 \\
\hline $2,4-D N P$ & 102 & 4 & 98 & 1 & 117 & 3 & 105 & 1 & 92 & 2 & 91 & 3 & 110 & 1 & 100 & 3 \\
\hline 1,2-DNB (surrogate) & 122 & 7 & 116 & 7 & $134^{*}$ & 16 & 124 & 5 & 121 & 10 & 115 & 7 & $125^{*}$ & 3 & $125^{*}$ & 1 \\
\hline $1,3-\mathrm{DNB}$ & 121 & 4 & 114 & 1 & $134^{*}$ & 9 & $127 *$ & 2 & 119 & 4 & 115 & 2 & $125^{*}$ & 1 & $129^{*}$ & 5 \\
\hline $2-N P$ & 85 & 5 & 81 & 4 & 99 & 6 & 93 & 1 & 89 & 2 & 88 & 2 & 102 & 3 & 93 & 5 \\
\hline NB & 122 & 4 & 116 & 1 & $135^{*}$ & 9 & $128^{*}$ & 2 & 118 & 5 & 113 & 2 & 122 & $<0$ & $127 *$ & 5 \\
\hline 3,5-DNA $(254 \mathrm{~nm})$ & $75^{*}$ & 3 & $72 *$ & 4 & 84 & 9 & 79 & 2 & 96 & 5 & 93 & 1 & 101 & 1 & 103 & 3 \\
\hline$D N A N$ & 120 & 4 & 114 & 2 & $133^{*}$ & 7 & $129^{*}$ & 1 & 117 & 4 & 110 & 2 & 119 & 2 & $127^{*}$ & 4 \\
\hline Tetryl & 93 & 11 & 93 & 5 & 118 & 6 & 113 & 6 & 99 & 4 & 98 & 2 & 111 & 3 & 111 & 1 \\
\hline NG & 114 & 11 & 106 & 8 & $125^{*}$ & 17 & 118 & 13 & 106 & 7 & 108 & 9 & 116 & 10 & 114 & 5 \\
\hline 2,4,6-TNT & $128^{*}$ & 5 & 119 & 2 & $138+$ & 12 & $130^{*}$ & 5 & 116 & 2 & 112 & 4 & 119 & 2 & 124 & 3 \\
\hline 4-Am-2,6-DNT & $126^{*}$ & 4 & 118 & 1 & $137 \dagger$ & 9 & $130^{*}$ & 2 & 121 & 4 & 117 & 4 & $126^{*}$ & 1 & $127^{*}$ & 2 \\
\hline 2-Am-4,6-DNT & 123 & 4 & 117 & 1 & $136 \dagger$ & 9 & $129^{*}$ & 2 & 119 & 4 & 113 & 2 & 122 & 1 & $126^{*}$ & 2 \\
\hline 2,6-DNT & 116 & 11 & 109 & 6 & $132 *$ & 4 & 121 & 3 & 118 & 4 & 109 & 6 & 123 & 5 & 124 & 4 \\
\hline 2,4-DNT & 123 & 2 & 115 & 2 & $135^{*}$ & 8 & $127^{*}$ & 1 & 114 & 4 & 112 & 3 & 122 & 2 & $125^{*}$ & 3 \\
\hline 2-NT & 88 & 5 & 83 & 3 & 98 & 9 & 92 & 2 & 105 & 4 & 101 & 1 & 110 & 4 & 111 & 3 \\
\hline 4-NT & 97 & 2 & 93 & 3 & 110 & 10 & 104 & 1 & 110 & 6 & 105 & 3 & 114 & 2 & 117 & 5 \\
\hline $3-\mathrm{NT}$ & 94 & 4 & 88 & 4 & 101 & 10 & 97 & 1 & 103 & 6 & 101 & 2 & 108 & $<1$ & 111 & 1 \\
\hline PETN & 120 & 7 & 113 & 1 & $130^{*}$ & 11 & 123 & 2 & 117 & 5 & 115 & 3 & 123 & 1 & $126^{*}$ & 3 \\
\hline
\end{tabular}

Bold, italicized are IM compounds and degradation products.

Green: $75 \%-125 \%$; light green $(*): 64 \%-74 \%$ or $126 \%-135 \%$; red $(\dagger):<64 \%$ or $>135 \%$

(DoD QSM Ver5.2 for Solids-lowest LCL: 4-Am-2,6-DNT, 64\%; highest UCL: Tetryl, 135\%) 


\subsection{SE method for tissues}

Current USEPA Method 8330B and ERDC-EL SE methods were modified to enable extraction of all 24 compounds of interest (and 2 surrogates) from environmental tissue samples. A single ultrasonication period using $\mathrm{MeOH}$ was predicted to be sufficient for extraction of the 26 compounds, as the tissues used during method development experiments were not previously lyophilized, and, therefore, contained a significant portion of water. Initial tests led to the adoption of a single-step, $18 \mathrm{~h} \mathrm{MeOH}$ extraction. Additionally, an extract interference reduction method was needed (adapted from Larson et al. 1999), as all of the tissues (fathead minnow [Pimephales promelas], polychaete worm [Alitta virens], earthworm [Eisenia fetida], and ryegrass [Lolium perenne]) suffered from varying degrees of analytical interference because of coeluting nontarget extracted components.

Compound recoveries prior to application of the interference reduction procedure are shown in Table 17 for all four tissue types. The DoD QSM Ver5.2 UCL and LCL accepted limits for solid (soil) matrices analyzed by USEPA Method 8330B were used as a benchmark (64\%-135\%), as they were during the soil SE method development described previously, since limits have not been established specifically for tissues matrices. A single ultrasonication period of $18 \mathrm{~h}$ using $\mathrm{MeOH}$ was shown to be sufficient to extract the majority of compounds ( 17 from earthworm, 22 from polychaete worm, 24 from minnow, and 23 from ryegrass) within the accepted range for solids according to DoD QSM Ver5.2. Tetryl was the only compound generally recovered poorly from all three tested animal tissue types, at $<5 \%$. The scientific literature highlights the matrix- and temperature-dependent stability of Tetryl (Harvey et al. 1992; Jenkins 1994; Jenkins and Walsh 1994; Boopathy 2000; Douglas et al. 2009), which was consistent with current and previous results obtained at ERDCEL. For this reason, it may be beneficial to investigate reduced ultrasonication periods to determine whether the full $18 \mathrm{~h}$ period is necessary for efficient recovery of the other compounds of interest or whether Tetryl recovery could be improved by having a shorter time period during which degradation could occur. While no compound stability studies were performed in tissue matrices for the current work, results for water and soil matrices are shown and discussed in section 3.9, with results for Tetryl consistent with referenced literature. 
Table 17. Recoveries (\%) from four laboratory-spiked tissues using one $18 \mathrm{~h}$ ultrasonic extraction with $\mathrm{MeOH}$, prior to undergoing chromatographic treatment to reduce analytical interference. (AVG = average; $S D=$ standard deviation)

\begin{tabular}{|c|c|c|c|c|c|c|c|c|}
\hline \multirow[b]{3}{*}{ Compound } & \multicolumn{8}{|c|}{ Recoveries (\%) } \\
\hline & \multicolumn{2}{|c|}{ Fathead minnow } & \multicolumn{2}{|c|}{ Earthworm } & \multicolumn{2}{|c|}{ Polychaete worm } & \multicolumn{2}{|c|}{ Ryegrass } \\
\hline & $\begin{array}{l}\text { AVG } \\
(n=4)\end{array}$ & SD & $\begin{array}{l}\text { AVG } \\
(n=2)\end{array}$ & SD & $\begin{array}{l}\text { AVG } \\
(n=5)\end{array}$ & SD & $\begin{array}{l}\text { AVG } \\
(n=3)\end{array}$ & SD \\
\hline$N Q$ & $73^{*}$ & 18.0 & $59+$ & 5.1 & $140+$ & 134.2 & 99 & 6.0 \\
\hline NTO $(210 \mathrm{~nm})$ & $1,112 \uparrow$ & 325.3 & $668+$ & 133.7 & $395+$ & 122.7 & $12 \uparrow$ & 1.4 \\
\hline o-NBA (surr.) & 85 & 6.7 & $54 \dagger$ & 35.3 & 119 & 14.5 & $24 \dagger$ & 1.8 \\
\hline HMX & 76 & 2.5 & 89 & 27.6 & $72 *$ & 2.9 & 81 & 7.2 \\
\hline RDX & $73 *$ & 1.1 & 84 & 18.8 & $74 *$ & 1.4 & 86 & 9.9 \\
\hline$P A(210 \mathrm{~nm})$ & 77 & 20.7 & 419+ & 335.8 & $60+$ & 4.5 & 85 & 9.1 \\
\hline 4-NP & 102 & 15.4 & 110 & 34.4 & 79 & 1.0 & 89 & 5.6 \\
\hline 1,3,5-TNB & $72 *$ & 4.0 & $234 \dagger$ & 192.7 & $74 *$ & 2.4 & 87 & 6.6 \\
\hline $2,4-D N P$ & 79 & 1.7 & 96 & 21.6 & 77 & 2.1 & 110 & 6.9 \\
\hline 1,2-DNB (surr.) & 82 & 0.6 & 83 & 2.4 & 82 & 0.8 & 86 & 7.5 \\
\hline 1,3-DNB & $74 *$ & 0.6 & 76 & 2.9 & $74 *$ & 0.8 & 87 & 7.0 \\
\hline $2-N P$ & $68 *$ & 1.5 & $69 *$ & 2.2 & $68 *$ & 1.8 & 86 & 6.7 \\
\hline NB & $75^{*}$ & 0.8 & 79 & 1.3 & $74 *$ & 1.7 & 87 & 7.6 \\
\hline 3,5-DNA (254 nm) & 83 & 2.2 & 85 & 2.6 & 83 & 1.0 & 90 & 7.0 \\
\hline$D N A N$ & $70 *$ & 6.8 & $73^{*}$ & 3.8 & $70 *$ & 2.5 & 90 & 6.4 \\
\hline Tetryl & $3+$ & 3.2 & $2 \dagger$ & 2.1 & $4 \dagger$ & 1.8 & $51+$ & 16.5 \\
\hline$N G$ & $73 *$ & 3.7 & $74 *$ & 0.1 & $72 *$ & 0.6 & 85 & 5.5 \\
\hline 2,4,6-TNT & $73 *$ & 3.9 & 77 & 1.3 & $74 *$ & 1.3 & 87 & 6.7 \\
\hline 4-Am-2,6-DNT & 75 & 3.4 & 78 & 0.8 & $73 *$ & 0.8 & 93 & 8.2 \\
\hline 2-Am-4,6-DNT & $73 *$ & 2.0 & 77 & 1.9 & $74 *$ & 1.3 & 94 & 7.3 \\
\hline 2,6-DNT & 91 & 17.3 & 85 & 5.0 & 82 & 2.4 & 88 & 7.2 \\
\hline 2,4-DNT & $74 *$ & 7.3 & $72 *$ & 4.3 & $71 *$ & 2.4 & 87 & 7.4 \\
\hline 2-NT & 79 & 1.0 & 82 & 0.1 & 76 & 2.3 & 87 & 7.1 \\
\hline 4-NT & 76 & 1.9 & 80 & 3.6 & $70 *$ & 3.7 & 89 & 5.4 \\
\hline 3-NT & 79 & 2.0 & 80 & 3.5 & 80 & 3.6 & 89 & 6.8 \\
\hline PETN & $72 *$ & 3.2 & $73 *$ & 2.7 & 83 & 10.2 & 92 & 5.1 \\
\hline
\end{tabular}

Bold, italicized are IM compounds and degradation products.

Green: $75 \%-125 \%$; light green (*): $64 \%-74 \%$ or $126 \%-135 \%$; red (†): $<64 \%$ or $>135 \%$

(DoD QSM Ver5.2 for Solids-lowest LCL: 4-Am-2,6-DNT, 64\%; highest UCL: Tetryl, 135\%) 
UV chromatograms of both unspiked and spiked tissue samples (not shown) revealed the presence of nontarget matrix components for each tissue type, with the majority occurring toward the beginning of the chromatographic separation ( $\mathrm{o}-16 \mathrm{~min}$ ), indicating more polar interferents. The presence of these components resulted in observed positive interferences for the more polar compounds of interest (mainly NQ, NTO, and PA), with the worst interference observed for earthworm tissue. Matrix-based analytical interferences occurred in three chromatographic regions for earthworm tissue, which resulted in large positive interference and very high recovery rates for NTO, PA, and 1,3,5TNB. In addition, NQ and $o$-NBA surrogate were recovered but not quite within current QSM accepted limits. Compound recovery from polychaete worm tissue was similar to earthworm tissue. However, positive interference was observed for NQ, PA recovery was slightly low, and 1,3,5TNB analysis was not affected by interference. Positive interference was still observed for NTO but to a lesser extent. For the fathead minnows, positive interference again inhibited accurate determination of NTO. No positive chromatographic interference was observed for ryegrass tissue; however, neither NTO (12\%) nor o-NBA (24\%) was recovered within current accepted QSM limits. The analytical interferences could have been due to coelution or coextraction of nontarget compounds that interfered with NTO or $o$-NBA detection during the HPLC analytical method, arising from $\mathrm{pH}$-related or other interactions. Therefore, it was predicted that subjecting plant tissue samples to an appropriate interference reduction procedure might eliminate these interferences as well. Interestingly, Tetryl recovery was approximately $50 \%$ from plant tissue, whereas it was $<5 \%$ for all animal tissue types.

\subsection{Chromatographic interference reduction method for tissue extracts}

Because of the chromatographic results obtained during tissue extraction method development, an interference reduction procedure for tissue matrix interferences was necessary to obtain accurate and reliable results for tissue extract analysis, especially extracts known or suspected of containing the more polar IM compounds like NQ, NTO, and PA. Furthermore, as mentioned briefly in section 2.8 , at cold temperatures, some tissue $\mathrm{MeOH}$ extracts developed a precipitate. This precipitation issue also occurred for certain extracts that had been prepared for analysis to a ratio of $50 / 50 \mathrm{MeOH} /$ water. The majority of the precipitation issue was observed for earthworm extracts, to a lesser extent for polychaete 
worm and minnow extracts, and not at all for ryegrass extracts. In the case of precipitation, samples underwent additional filtering at the point of collection or following dilution with reagent water in preparation for analysis. Additional filtering was performed using either a second $0.45 \mu \mathrm{m}$ PTFE hydrophobic or a $0.20 \mu \mathrm{m}$ Anotop 10 inorganic membrane disk filter. When HPLC-UV data for samples that had undergone additional filtering showed persistent chromatographic interference, further experiments were carried out to determine an effective interference reduction method.

As an alternative to additional filtration alone, either $0.1 \%$ or $1 \%$ TFA (final v/v) was added to $\mathrm{MeOH}$ extracts or 50/50 MeOH/water-prepared analytical samples to encourage "complete" precipitation, followed by additional filtering (if needed). The addition of acid yielded no further benefit than a second filtration step alone (data not shown). Therefore, a chromatographic interference reduction method was adapted from Larson et al (1999). Some changes were made to the method described in the original publication. The original $\mathrm{ACN}$ and basic alumina were changed to $\mathrm{MeOH}$ and neutral alumina, respectively. Instead of using a combination of alumina and florisil, either alumina or florisil was used initially to enable determination of the responsible component for the effect on HPLC-UV chromatography for each compound of interest. Initial trials of the adapted chromatographic method were performed only on polychaete worms (Table 18). For the experiment shown, treatment with alumina removed all of the analytical interferences, and even resulted in improved recoveries for many other compounds; however, it also caused a reduction in the detected $o$-NBA surrogate to $39 \%$. Meanwhile, treatment with florisil proved similar; however, both NTO and $o$-NBA recoveries were reduced to levels below the accepted DoD QSM Ver5.2 lower limit of 64\%.

Because of the preliminary success with the alumina and florisil methods, the same tests were repeated, using all four tissue matrices, shown in Table 19, with similar results. Further interference reduction methods were investigated, including mixed combinations of neutral alumina and florisil as well as basic alumina and silica. For these tests, $\mathrm{MeOH}$ extracts were obtained via $18 \mathrm{~h}$ ultrasonication of unspiked tissue. Post-extraction spiked $\mathrm{MeOH}$ extracts underwent chromatographic treatment as described in section 2.8. Compound recoveries (\%) for each tissue type using each of the five chromatographic methods are shown in Tables 18-23. 
Table 18. Recoveries (\%) from laboratory-spiked polychaete worm tissue $\mathrm{MeOH}$ extracts following either neutral alumina or florisil chromatographic treatment for interference reduction. (AVG = average; $S D=$ standard deviation)

\begin{tabular}{|c|c|c|c|c|}
\hline \multirow[b]{3}{*}{ Compound } & \multicolumn{4}{|c|}{ Polychaete worm-recoveries (\%) } \\
\hline & \multicolumn{2}{|c|}{ Alumina column } & \multicolumn{2}{|c|}{ Florisil column } \\
\hline & $\begin{array}{l}\text { AVG } \\
(n=2)\end{array}$ & SD & $\begin{array}{l}\text { AVG } \\
(n=2)\end{array}$ & SD \\
\hline$N Q$ & 117 & 5.0 & $129 *$ & 13.7 \\
\hline NTO $(210 \mathrm{~nm})$ & 93 & 16.2 & $26+$ & 4.2 \\
\hline o-NBA (surrogate) & $39+$ & 1.4 & $24+$ & 27.9 \\
\hline $\mathrm{HMX}$ & 82 & 2.0 & 90 & 3.3 \\
\hline RDX & 109 & 5.7 & 95 & 16.3 \\
\hline$P A(210 \mathrm{~nm})$ & 88 & 2.7 & 90 & 3.9 \\
\hline 4-NP & 92 & 2.1 & 97 & 4.1 \\
\hline 1,3,5-TNB & 90 & 0.7 & 96 & 1.4 \\
\hline 2,4-DNP & 95 & 0.5 & 96 & 4.6 \\
\hline 1,2-DNB (surrogate) & 91 & 2.3 & 96 & 2.4 \\
\hline 1,3-DNB & 91 & 1.1 & 96 & 2.1 \\
\hline $2-N P$ & $70 *$ & 3.4 & $71^{*}$ & 2.6 \\
\hline NB & 88 & 1.4 & 94 & 2.7 \\
\hline 3,5-DNA (254 nm) & 97 & 2.7 & 97 & 3.4 \\
\hline DNAN & 78 & 1.5 & 85 & 0.6 \\
\hline Tetryl & $4 \dagger$ & 0.3 & $5+$ & 1.6 \\
\hline$N G$ & 95 & 3.6 & 96 & 9.1 \\
\hline 2,4,6-TNT & 92 & 0.1 & 97 & 2.1 \\
\hline 4-Am-2,6-DNT & 87 & 0.7 & 91 & 4.3 \\
\hline 2-Am-4,6-DNT & 90 & 0.6 & 92 & 4.9 \\
\hline 2,6-DNT & 88 & 1.3 & 95 & 1.4 \\
\hline 2,4-DNT & 88 & 0.2 & 90 & 2.5 \\
\hline 2-NT & 98 & 4.1 & 94 & 13.9 \\
\hline 4-NT & 89 & 2.9 & 91 & 1.6 \\
\hline 3-NT & 98 & 3.6 & 103 & 2.6 \\
\hline PETN & 84 & 4.5 & 85 & 1.4 \\
\hline
\end{tabular}

Bold, italicized are IM compounds and degradation products.

Green: $75 \%-125 \%$; light green (*): $64 \%-74 \%$ or $126 \%-135 \%$; red $(\dagger):<64 \%$ or $>135 \%$ (DoD QSM Ver5.2 for Solids-lowest LCL: 4-Am-2,6-DNT, 64\%; highest UCL: Tetryl, 135\%) 
Table 19. Recoveries (\%) from laboratory-spiked tissues $\mathrm{MeOH}$ extract, following no interference reduction treatment, or treatment with either neutral alumina or florisil. (AVG = average; $S D=$ standard deviation)

\begin{tabular}{|c|c|c|c|c|c|c|c|c|c|c|c|c|}
\hline \multirow[b]{4}{*}{ Compound } & \multicolumn{12}{|c|}{ Recoveries (\%) } \\
\hline & \multicolumn{6}{|c|}{ Fathead minnow } & \multicolumn{6}{|c|}{ Earthworm } \\
\hline & \multicolumn{2}{|c|}{$\begin{array}{l}\text { No } \\
\text { chromatographic } \\
\text { interference } \\
\text { reduction }\end{array}$} & \multicolumn{2}{|c|}{ Alumina column } & \multicolumn{2}{|c|}{ Florisil column } & \multicolumn{2}{|c|}{$\begin{array}{l}\text { No } \\
\text { chromatographic } \\
\text { interference } \\
\text { reduction }\end{array}$} & \multicolumn{2}{|c|}{ Alumina column } & \multicolumn{2}{|c|}{ Florisil column } \\
\hline & $\begin{array}{l}\text { AVG } \\
(n=3)\end{array}$ & SD & $\begin{array}{l}\text { AVG } \\
(n=3)\end{array}$ & SD & $\begin{array}{l}\text { AVG } \\
(n=3)\end{array}$ & SD & $\begin{array}{l}\text { AVG } \\
(n=3)\end{array}$ & SD & $\begin{array}{l}\text { AVG } \\
(n=3)\end{array}$ & SD & $\begin{array}{l}\text { AVG } \\
(n=3)\end{array}$ & SD \\
\hline$N Q$ & $398+$ & 33.6 & $238+$ & 20.3 & $280+$ & 30.1 & 88 & 4.0 & $203+$ & 77.8 & $162+$ & 21.9 \\
\hline NTO $(210 \mathrm{~nm})$ & $4,363+$ & 422.6 & $4,441 \dagger$ & 81.1 & $5,659 \dagger$ & 723.5 & $3,095 \dagger$ & 346.1 & $3,532 \dagger$ & $1,845.6$ & $5,994 \dagger$ & $1,205.5$ \\
\hline NTO $(315 \mathrm{~nm})$ & $21 \dagger$ & 8.7 & 114 & 10.6 & $140 \dagger$ & 8.0 & $16+$ & 3.0 & $129 *$ & 10.1 & $162 \dagger$ & 5.1 \\
\hline o-NBA (surrogate) & 93 & 4.3 & 82 & 4.3 & 98 & 4.0 & $52 \dagger$ & 3.8 & 79 & 6.8 & 82 & 1.8 \\
\hline HMX & 87 & 2.6 & 88 & 5.7 & 96 & 1.6 & 102 & 5.0 & $60+$ & 6.0 & $54 \dagger$ & 2.1 \\
\hline RDX & 88 & 2.3 & 93 & 2.5 & 96 & 5.2 & 94 & 6.3 & 108 & 4.4 & 88 & 3.2 \\
\hline$P A(210 n m)$ & $70 *$ & 7.4 & 78 & 3.5 & 81 & 6.6 & $719+$ & 36.8 & $165 \dagger$ & 135.6 & $360+$ & 44.2 \\
\hline$P A(315 n m)$ & $71 *$ & 1.7 & $68 *$ & 2.4 & $73 *$ & 2.3 & $51 \dagger$ & 2.0 & $\boldsymbol{\theta}_{\dagger}$ & 0.0 & $7 \dagger$ & 0.4 \\
\hline 4-NP & 101 & 1.9 & 97 & 3.1 & 104 & 4.5 & $57 \dagger$ & 2.4 & $48+$ & 6.3 & $48+$ & 3.5 \\
\hline $1,3,5-\mathrm{TNB}$ & $52 \dagger$ & 0.6 & $64 *$ & 6.1 & $54+$ & 1.5 & $53+$ & 1.5 & $59+$ & 2.9 & $57 \dagger$ & 3.4 \\
\hline $2,4-D N P$ & $66 *$ & 1.9 & $62 \dagger$ & 3.0 & $73 *$ & 4.2 & $63+$ & 5.7 & $71 *$ & 4.9 & $67 *$ & 5.0 \\
\hline 1,2-DNB (surrogate) & 80 & 0.1 & 81 & 3.7 & 82 & 4.3 & 76 & 0.6 & 78 & 6.6 & 84 & 6.3 \\
\hline $1,3-\mathrm{DNB}$ & 89 & 1.4 & 90 & 3.5 & 94 & 1.4 & 76 & 1.3 & 79 & 0.9 & 78 & 2.4 \\
\hline $2-N P$ & 92 & 1.6 & 80 & 2.8 & 87 & 1.6 & $73 *$ & 1.9 & $67 *$ & 1.6 & $72 *$ & 4.1 \\
\hline NB & 78 & 1.2 & $75 *$ & 6.4 & 77 & 0.7 & $73 *$ & 1.2 & 77 & 3.8 & 77 & 3.7 \\
\hline 3,5-DNA (210nm) & 92 & 1.7 & 92 & 3.8 & 99 & 7.3 & 79 & 4.6 & 82 & 1.3 & 84 & 7.4 \\
\hline 3,5-DNA $(254 \mathrm{~nm})$ & 97 & 2.2 & 104 & 2.3 & 104 & 3.5 & 85 & 2.0 & 89 & 3.9 & 93 & 5.5 \\
\hline$D N A N$ & 107 & 3.2 & 107 & 3.9 & 109 & 6.1 & 76 & 2.4 & 89 & 2.9 & 92 & 2.2 \\
\hline Tetryl & $2 \dagger$ & 2.8 & $0 \dagger$ & 0.0 & $0 \dagger$ & 0.0 & $7 \dagger$ & 6.4 & $11 \dagger$ & 2.1 & $12 \dagger$ & 2.3 \\
\hline $\mathrm{NG}$ & $42 \dagger$ & 3.5 & $36+$ & 7.2 & $44 \dagger$ & 4.5 & $39+$ & 4.6 & $41 \dagger$ & 2.8 & $45 t$ & 2.7 \\
\hline $2,4,6-\mathrm{TNT}$ & 78 & 2.1 & 90 & 3.4 & 87 & 4.6 & $71 *$ & 2.7 & 87 & 1.6 & 86 & 2.8 \\
\hline
\end{tabular}




\begin{tabular}{|c|c|c|c|c|c|c|c|c|c|c|c|c|}
\hline \multirow[b]{4}{*}{ Compound } & \multicolumn{12}{|c|}{ Recoveries (\%) } \\
\hline & \multicolumn{6}{|c|}{ Fathead minnow } & \multicolumn{6}{|c|}{ Earthworm } \\
\hline & \multicolumn{2}{|c|}{$\begin{array}{l}\text { No } \\
\text { chromatographic } \\
\text { interference } \\
\text { reduction }\end{array}$} & \multicolumn{2}{|c|}{ Alumina column } & \multicolumn{2}{|c|}{ Florisil column } & \multicolumn{2}{|c|}{$\begin{array}{l}\text { No } \\
\text { chromatographic } \\
\text { interference } \\
\text { reduction }\end{array}$} & \multicolumn{2}{|c|}{ Alumina column } & \multicolumn{2}{|c|}{ Florisil column } \\
\hline & $\begin{array}{l}\text { AVG } \\
(n=3)\end{array}$ & SD & $\begin{array}{l}\text { AVG } \\
(n=3)\end{array}$ & SD & $\begin{array}{l}\text { AVG } \\
(n=3)\end{array}$ & SD & $\begin{array}{l}\text { AVG } \\
(n=3)\end{array}$ & SD & $\begin{array}{l}\text { AVG } \\
(n=3)\end{array}$ & SD & $\begin{array}{l}\text { AVG } \\
(n=3)\end{array}$ & SD \\
\hline 4-Am-2,6-DNT & $67 *$ & 0.5 & $66^{*}$ & 3.3 & $64 *$ & 5.5 & $64 \dagger$ & 2.3 & $69 *$ & 4.2 & $68 *$ & 3.0 \\
\hline 2-Am-4,6-DNT & 83 & 2.2 & 82 & 3.7 & 86 & 1.8 & $73 *$ & 2.5 & 79 & 2.8 & 77 & 9.5 \\
\hline 2,6-DNT & 88 & 6.0 & 96 & 4.3 & 100 & 0.4 & $72 *$ & 4.3 & $74 *$ & 2.7 & $72 *$ & 2.7 \\
\hline 2,4-DNT & 88 & 4.8 & 88 & 1.4 & 94 & 3.0 & $72 *$ & 2.7 & $75 *$ & 1.3 & 76 & 2.3 \\
\hline 2-NT & 91 & 3.2 & 91 & 5.0 & 97 & 6.8 & 77 & 5.7 & $75 *$ & 3.1 & 94 & 9.1 \\
\hline 4-NT & 86 & 1.2 & 78 & 7.5 & 88 & 3.4 & $71 *$ & 2.9 & $73 *$ & 7.8 & $70 *$ & 3.4 \\
\hline 3-NT & 85 & 2.4 & 88 & 2.1 & 97 & 1.3 & $71 *$ & 1.6 & 75 & 3.3 & $74 *$ & 2.7 \\
\hline PETN & $67 *$ & 5.6 & $59+$ & 1.6 & $65 *$ & 6.0 & $52 \dagger$ & 7.5 & $60 \dagger$ & 5.9 & $60 \dagger$ & 4.0 \\
\hline
\end{tabular}

Green: $75 \%-125 \%$; light green $(*)$ : $64 \%-74 \%$ or $126 \%-135 \%$; red $(\dagger):<64 \%$ or $>135 \%$

(DoD QSM Ver5.2 for Solids-lowest LCL: 4-Am-2,6-DNT, 64\%; highest UCL: Tetryl, 135\%)

Table 19 (continued). (AVG = average; SD = standard deviation)

\begin{tabular}{|c|c|c|c|c|c|c|c|c|c|c|c|c|}
\hline \multirow[b]{4}{*}{ Compound } & \multicolumn{12}{|c|}{ Recoveries (\%) } \\
\hline & \multicolumn{6}{|c|}{ Polychaete worm } & \multicolumn{6}{|c|}{ Ryegrass } \\
\hline & \multicolumn{2}{|c|}{$\begin{array}{l}\text { No } \\
\text { chromatographic } \\
\text { interference } \\
\text { reduction }\end{array}$} & \multicolumn{2}{|c|}{ Alumina column } & \multicolumn{2}{|c|}{ Florisil column } & \multicolumn{2}{|c|}{$\begin{array}{l}\text { No } \\
\text { chromatographic } \\
\text { interference } \\
\text { reduction }\end{array}$} & \multicolumn{2}{|c|}{ Alumina column } & \multicolumn{2}{|c|}{ Florisil column } \\
\hline & $\begin{array}{l}\text { AVG } \\
(n=3)\end{array}$ & SD & $\begin{array}{l}\text { AVG } \\
(n=3)\end{array}$ & SD & $\begin{array}{l}\text { AVG } \\
(n=3)\end{array}$ & SD & $\begin{array}{l}\text { AVG } \\
(n=3)\end{array}$ & SD & $\begin{array}{l}\text { AVG } \\
(n=3)\end{array}$ & SD & $\begin{array}{l}\text { AVG } \\
(n=3)\end{array}$ & SD \\
\hline NTO $(210 \mathrm{~nm})$ & $1,613 \dagger$ & 202.6 & 1,955 & 372.4 & 3,060 & 99.2 & 1,612 & 92.2 & 984 & 258.5 & 1,084 & $1,094.1$ \\
\hline NTO (315nm) & $20 \dagger$ & 1.9 & 109 & 11.6 & 174 & 11.2 & 8 & 5.7 & 86 & 27.9 & 363 & 493.2 \\
\hline
\end{tabular}




\begin{tabular}{|c|c|c|c|c|c|c|c|c|c|c|c|c|}
\hline \multirow[b]{4}{*}{ Compound } & \multicolumn{12}{|c|}{ Recoveries (\%) } \\
\hline & \multicolumn{6}{|c|}{ Polychaete worm } & \multicolumn{6}{|c|}{ Ryegrass } \\
\hline & \multicolumn{2}{|c|}{$\begin{array}{l}\text { No } \\
\text { chromatographic } \\
\text { interference } \\
\text { reduction }\end{array}$} & \multicolumn{2}{|c|}{ Alumina column } & \multicolumn{2}{|c|}{ Florisil column } & \multicolumn{2}{|c|}{$\begin{array}{l}\text { No } \\
\text { chromatographic } \\
\text { interference } \\
\text { reduction }\end{array}$} & \multicolumn{2}{|c|}{ Alumina column } & \multicolumn{2}{|c|}{ Florisil column } \\
\hline & $\begin{array}{l}\text { AVG } \\
(n=3)\end{array}$ & SD & $\begin{array}{l}\text { AVG } \\
(n=3)\end{array}$ & SD & $\begin{array}{l}\text { AVG } \\
(n=3)\end{array}$ & SD & $\begin{array}{l}\text { AVG } \\
(n=3)\end{array}$ & SD & $\begin{array}{l}\text { AVG } \\
(n=3)\end{array}$ & SD & $\begin{array}{l}\text { AVG } \\
(n=3)\end{array}$ & SD \\
\hline HMX & $68 *$ & 6.7 & $71 *$ & 2.0 & $71 *$ & 2.2 & 75 & 6.4 & 85 & 5.0 & $68 *$ & 23.1 \\
\hline RDX & 77 & 0.9 & 77 & 2.6 & 76 & 1.4 & 97 & 3.3 & 88 & 6.8 & 89 & 18.8 \\
\hline$P A(210 n m)$ & 75 * & 5.0 & 83 & 8.5 & 106 & 5.1 & $141 \dagger$ & 27.4 & $57 \dagger$ & 7.0 & 89 & 52.8 \\
\hline$P A(315 n m)$ & $67 *$ & 0.4 & $65 *$ & 3.7 & $64 *$ & 4.8 & 78 & 4.4 & 76 & 14.2 & 65 * & 21.5 \\
\hline 4-NP & 75 * & 0.6 & 75 & 1.3 & 78 & 1.2 & 83 & 4.5 & 81 & 3.5 & 78 & 12.3 \\
\hline $1,3,5$-TNB & $47 \dagger$ & 0.8 & $47 \dagger$ & 0.4 & $46 \dagger$ & 5.8 & 75 & 3.6 & 86 & 6.6 & 75 * & 20.2 \\
\hline 2-NP & 75 * & 3.4 & $66^{*}$ & 4.5 & $67 *$ & 1.8 & $73 *$ & 1.8 & $63+$ & 3.5 & $66^{*}$ & 11.4 \\
\hline NB & $60 t$ & 1.5 & $59+$ & 1.2 & $62+$ & 4.1 & $74 *$ & 3.7 & $66^{*}$ & 4.3 & $66^{*}$ & 16.8 \\
\hline 3,5 -DNA $(210 \mathrm{~nm})$ & 78 & 1.2 & 82 & 1.5 & 85 & 7.1 & $72 *$ & 1.8 & 70 * & 2.8 & $67 *$ & 15.5 \\
\hline $3,5-\mathrm{DNA}(254 \mathrm{~nm})$ & 81 & 3.0 & 81 & 4.6 & 86 & 5.9 & $72 *$ & 0.4 & $74 *$ & 5.1 & $71 *$ & 16.2 \\
\hline DNAN & 79 & 3.2 & $73 *$ & 1.6 & 77 & 5.0 & 83 & 1.1 & 82 & 8.1 & $69 *$ & 9.8 \\
\hline Tetryl & $0 \dagger$ & 0.0 & $0+$ & 0.0 & $0+$ & 0.0 & $20+$ & 2.6 & $17 \dagger$ & 2.2 & $18+$ & 0.9 \\
\hline NG & $68 *$ & 4.9 & $67 *$ & 7.4 & $63+$ & 2.4 & 104 & 4.9 & 104 & 9.1 & 86 & 19.1 \\
\hline 2,4,6-TNT & $64 \dagger$ & 1.7 & $64 *$ & 5.6 & $60 \dagger$ & 5.9 & $75 *$ & 4.6 & $75 *$ & 3.5 & $70 *$ & 13.0 \\
\hline 4-Am-2,6-DNT & $44 \dagger$ & 0.4 & $44 \dagger$ & 5.6 & $48+$ & 1.2 & $61 \dagger$ & 16.8 & $45+$ & 4.8 & $42 \dagger$ & 9.4 \\
\hline 2-Am-4,6-DNT & $65 *$ & 1.2 & $64 t$ & 6.6 & $68 *$ & 2.8 & $72 *$ & 7.8 & $73 *$ & 4.2 & $65 *$ & 11.9 \\
\hline 2,6-DNT & 80 & 1.5 & $75 *$ & 4.1 & 79 & 3.7 & $75 *$ & 3.7 & $72 *$ & 3.1 & $67 *$ & 20.2 \\
\hline
\end{tabular}




\begin{tabular}{|c|c|c|c|c|c|c|c|c|c|c|c|c|}
\hline \multirow[b]{4}{*}{ Compound } & \multicolumn{12}{|c|}{ Recoveries (\%) } \\
\hline & \multicolumn{6}{|c|}{ Polychaete worm } & \multicolumn{6}{|c|}{ Ryegrass } \\
\hline & \multicolumn{2}{|c|}{$\begin{array}{l}\text { No } \\
\text { chromatographic } \\
\text { interference } \\
\text { reduction }\end{array}$} & \multicolumn{2}{|c|}{ Alumina column } & \multicolumn{2}{|c|}{ Florisil column } & \multicolumn{2}{|c|}{$\begin{array}{l}\text { No } \\
\text { chromatographic } \\
\text { interference } \\
\text { reduction }\end{array}$} & \multicolumn{2}{|c|}{ Alumina column } & \multicolumn{2}{|c|}{ Florisil column } \\
\hline & $\begin{array}{l}\text { AVG } \\
(n=3)\end{array}$ & SD & $\begin{array}{l}\text { AVG } \\
(n=3)\end{array}$ & SD & $\begin{array}{l}\text { AVG } \\
(n=3)\end{array}$ & SD & $\begin{array}{l}\text { AVG } \\
(n=3)\end{array}$ & SD & $\begin{array}{l}\text { AVG } \\
(n=3)\end{array}$ & SD & $\begin{array}{l}\text { AVG } \\
(n=3)\end{array}$ & SD \\
\hline 4-NT & 86 & 4.8 & $69 *$ & 6.1 & $75 *$ & 3.8 & $73 *$ & 6.7 & 75 & 4.2 & $62 \dagger$ & 12.1 \\
\hline $3-\mathrm{NT}$ & 81 & 4.4 & 79 & 3.5 & 82 & 1.9 & $68 *$ & 2.9 & $73 *$ & 1.4 & $64 *$ & 9.1 \\
\hline PETN & $61 \dagger$ & 2.2 & $57 \dagger$ & 2.0 & $59+$ & 2.5 & 82 & 7.4 & $74 *$ & 7.2 & $72 *$ & 10.7 \\
\hline
\end{tabular}

Green: $75 \%-125 \%$; light green $(*): 64 \%-74 \%$ or $126 \%-135 \%$; red $(\dagger):<64 \%$ or $>135 \%$ (DoD QSM Ver5.2 for Solids-lowest LCL: 4-Am-2,6-DNT, 64\%; highest UCL: Tetryl, 135\%) 
Each chromatographic treatment option was effective for fathead minnow tissue (Table 20). A reduction of NQ recovery was observed for neutral alumina-florisil combinations (to $77 \%-81 \%$ ), compared to a positive NQ interference introduced by basic alumina ( $150 \%$ recovery). With the exception of a slightly higher than acceptable recovery for NTO using the silica gel option (141\%), NTO detected at $315 \mathrm{~nm}$ (detection wavelength selection discussed below) was within DoD QSM Ver5.2 accepted limits $(64 \%-135 \%)$ for each treatment option.

For earthworm tissue (Table 21), again several chromatographic treatment options were successful at reducing or eliminating matrix-related interference. For the three neutral alumina-florisil combinations, all compounds were recovered within current DoD QSM Ver5.2 accepted limits. The silica gel option resulted in acceptable recoveries for all compounds as well, with the exception of NTO, which was slightly high at $138 \%$. Treatment with basic alumina resulted in three out-of-spec recoveries, including $o$-NBA surrogate (146\%), Tetryl (58\%), and NG $(169 \%)$.

For polychaete worm tissue (Table 22), analytical interferences were previously observed for NQ, NTO, and $o$-NBA surrogate. All five chromatographic interference reduction options resulted in $o$-NBA recoveries of approximately $100 \%$. NTO interference was also greatly reduced. NTO recoveries were only slightly above the accepted limit (135\%) for mixed neutral alumina-florisil (136\%) and silica gel (140\%) and within limits for two stacked alumina-florisil options (132\%-134\%). Unlike for other tissue types, polychaete worm tissue also suffered from analytical interference of NQ. All five chromatographic treatments were able to reduce this interference as well, with the silica gel option yielding the best NQ recovery result (92\%), followed by basic alumina (80\%) and mixed neutral alumina-florisil (72\%). Neither stacked neutral aluminaflorisil option completely removed the NQ interference. However, because each chromatographic interference removal procedure tested demonstrated specific successes and failures, all remain options for specific applications if needed.

For ryegrass plant tissue (Table 23), analytical interferences were observed for NQ, NTO, $o$-NBA surrogate, and 2,4-DNP in the original untreated extracts. With each of the five chromatographic options, the NQ and the 
2,4-DNP interferences were completely removed. In addition, all but the mixed neutral alumina-florisil were able to remove the $o$-NBA interference to yield recoveries within or just above the accepted DoD QSM Ver5.2 limit. Meanwhile, NTO interference was reduced by all but the basic alumina option. On the basis of the results from all four tissue types using each of the five chromatographic options, the silica gel option was chosen as the preferred option. This choice was made because of (1) the ability to remove the majority of interferences from the majority of tissue matrices, (2) the generally higher recoveries, and (3) the simplicity as compared to a combination of neutral alumina-florisil, which typically yielded similar recovery results. 
Table 20. Recoveries (\%) from postextraction spiked fathead minnow tissue MeOH extract, following five different chromatographic treatment options for matrix-related analytical interference reduction.

( $A V G=$ average $; \mathrm{SD}=$ standard deviation $)$

\begin{tabular}{|c|c|c|c|c|c|c|c|c|c|c|}
\hline \multirow[b]{3}{*}{ Compound } & \multicolumn{10}{|c|}{ Fathead minnow-recoveries (\%) } \\
\hline & \multicolumn{2}{|c|}{$\left.\right|_{\text {florisil }} ^{\text {Neutral alumina }}$} & \multicolumn{2}{|c|}{$\left.\right|_{\text {neutral alumina }} ^{\text {Florisil }}$} & \multicolumn{2}{|c|}{$\begin{array}{l}\text { Mixed neutral } \\
\text { alumina-florisil }\end{array}$} & \multicolumn{2}{|c|}{ Basic alumina } & \multicolumn{2}{|c|}{ Silica gel } \\
\hline & $\begin{array}{l}\text { AVG } \\
(n=3)\end{array}$ & SD & $\begin{array}{l}\text { AVG } \\
(n=2)\end{array}$ & SD & $\begin{array}{l}\text { AVG } \\
(n=3)\end{array}$ & SD & $\begin{array}{l}\text { AVG } \\
(n=3)\end{array}$ & SD & $\begin{array}{l}\text { AVG } \\
(n=3)\end{array}$ & SD \\
\hline$N Q$ & 81 & 6.7 & 81 & 0.7 & 77 & 9.8 & $150 \dagger$ & 8.7 & 92 & 4.7 \\
\hline NTO (210nm) & $2,280 \dagger$ & 747.3 & $1,766+$ & 41.0 & $1,797 \dagger$ & 157.0 & $3,924 \dagger$ & 189.3 & $2,054 \dagger$ & 179.0 \\
\hline NTO (315nm) & $130 *$ & 1.7 & 116 & 2.0 & 119 & 9.4 & $127 *$ & 10.6 & $141 \dagger$ & 5.3 \\
\hline o-NBA (surrogate) & 100 & 3.6 & 93 & 0.1 & 96 & 5.3 & 105 & 2.8 & 95 & 5.4 \\
\hline HMX & 104 & 9.9 & 94 & 1.5 & 94 & 6.3 & 100 & 4.1 & 98 & 3.3 \\
\hline RDX & 99 & 3.5 & 97 & 1.5 & 94 & 9.7 & 106 & 1.1 & 99 & 2.9 \\
\hline$P A(210 n m)$ & 119 & 29.2 & 115 & 31.0 & $127 *$ & 60.9 & 101 & 3.7 & 124 & 14.1 \\
\hline$P A(315 n m)$ & 96 & 3.3 & 97 & 0.7 & 99 & 2.5 & 121 & 7.2 & 99 & 3.6 \\
\hline 4-NP & 108 & 2.2 & 107 & 0.5 & 110 & 1.7 & 106 & 4.3 & 112 & 2.0 \\
\hline $1,3,5-\mathrm{TNB}$ & 102 & 4.5 & 97 & 4.6 & 97 & 3.4 & 97 & 4.5 & 106 & 4.1 \\
\hline $2,4-D N P$ & 106 & 9.7 & 91 & 2.7 & 98 & 7.6 & 96 & 1.5 & 94 & 4.2 \\
\hline 1,2-DNB (surrogate) & 101 & 3.3 & 97 & 3.7 & 97 & 6.8 & 102 & 4.6 & 100 & 4.6 \\
\hline $1,3-\mathrm{DNB}$ & 100 & 6.5 & 96 & 0.8 & 101 & 4.9 & 99 & 3.2 & 98 & 2.6 \\
\hline $2-N P$ & 106 & 25.8 & 90 & 0.9 & 104 & 18.5 & 97 & 2.5 & 92 & 4.3 \\
\hline NB & 95 & 4.8 & 96 & 5.1 & 93 & 11.3 & 97 & 4.1 & 96 & 1.0 \\
\hline 3,5-DNA (210nm) & 88 & 7.1 & 91 & 8.3 & 89 & 11.5 & 111 & 3.8 & 91 & 3.2 \\
\hline $3,5-\mathrm{DNA}(254 \mathrm{~nm})$ & 94 & 0.9 & 94 & 1.0 & 96 & 2.1 & 106 & 8.1 & 97 & 1.7 \\
\hline$D N A N$ & 104 & 3.5 & 100 & 10.8 & 98 & 10.8 & 101 & 8.1 & 104 & 3.7 \\
\hline Tetryl & 92 & 3.8 & 102 & 2.4 & 102 & 7.8 & 89 & 2.7 & 96 & 3.6 \\
\hline $\mathrm{NG}$ & 91 & 5.5 & 100 & 3.9 & 104 & 9.0 & 111 & 5.7 & 88 & 11.6 \\
\hline 2,4,6-TNT & 98 & 8.6 & 100 & 7.1 & 102 & 4.8 & 99 & 7.0 & 95 & 6.5 \\
\hline 4-Am-2,6-DNT & 94 & 7.1 & 93 & 0.5 & 97 & 3.5 & 92 & 3.9 & 88 & 3.8 \\
\hline
\end{tabular}




\begin{tabular}{|c|c|c|c|c|c|c|c|c|c|c|}
\hline \multirow[b]{3}{*}{ Compound } & \multicolumn{10}{|c|}{ Fathead minnow-recoveries (\%) } \\
\hline & \multicolumn{2}{|c|}{ Neutral alumina } & \multicolumn{2}{|c|}{$\left.\right|_{\text {neutral alumina }} ^{\text {Florisil }}$} & \multicolumn{2}{|c|}{$\begin{array}{l}\text { Mixed neutral } \\
\text { alumina-florisil }\end{array}$} & \multicolumn{2}{|c|}{ Basic alumina } & \multicolumn{2}{|c|}{ Silica gel } \\
\hline & $\begin{array}{l}\text { AVG } \\
(n=3)\end{array}$ & SD & $\begin{array}{l}\text { AVG } \\
(n=2)\end{array}$ & SD & $\begin{array}{l}\text { AVG } \\
(n=3)\end{array}$ & SD & $\begin{array}{l}\text { AVG } \\
(n=3)\end{array}$ & SD & $\begin{array}{l}\text { AVG } \\
(n=3)\end{array}$ & SD \\
\hline 2-Am-4,6-DNT & 102 & 10.5 & 97 & 3.9 & 104 & 6.4 & 97 & 5.6 & 99 & 7.4 \\
\hline 2,6-DNT & 106 & 12.6 & 120 & 2.2 & 98 & 8.5 & 104 & 5.8 & 96 & 6.2 \\
\hline 2,4-DNT & 97 & 1.7 & 98 & 2.2 & 99 & 5.9 & 97 & 7.1 & 101 & 3.8 \\
\hline 2-NT & 94 & 0.8 & 95 & 0.6 & 100 & 1.3 & 99 & 5.8 & 99 & 2.6 \\
\hline 4-NT & 101 & 14.0 & 94 & 0.3 & 100 & 5.0 & 96 & 7.3 & 97 & 4.6 \\
\hline $3-\mathrm{NT}$ & 96 & 3.7 & 98 & 6.1 & 101 & 2.6 & 98 & 8.9 & 97 & 5.8 \\
\hline PETN & 101 & 7.7 & 91 & 0.4 & 98 & 6.0 & 96 & 6.9 & 94 & 8.2 \\
\hline
\end{tabular}

Bold, italicized are IM compounds and degradation products.

Green: $75 \%-125 \%$; light green $(*): 64 \%-74 \%$ or $126 \%-135 \%$; red $(t):<64 \%$ or $>135 \%$

(DoD QSM Ver5.2 for Solids-lowest LCL: 4-Am-2,6-DNT, 64\%; highest UCL: Tetryl, 135\%) 
Table 21. Recoveries (\%) from postextraction spiked earthworm tissue $\mathrm{MeOH}$ extract, following five different chromatographic treatment options for matrix-related analytical interference reduction.

(AVG = average; $\mathrm{SD}=$ standard deviation)

\begin{tabular}{|c|c|c|c|c|c|c|c|c|c|c|}
\hline \multirow[b]{3}{*}{ Compound } & \multicolumn{10}{|c|}{ Earthworm-recoveries (\%) } \\
\hline & \multicolumn{2}{|c|}{ Neutral alumina } & \multicolumn{2}{|c|}{ neutral alumina } & \multicolumn{2}{|c|}{$\begin{array}{l}\text { Mixed neutral } \\
\text { alumina-florisil }\end{array}$} & \multicolumn{2}{|c|}{ Basic alumina } & \multicolumn{2}{|c|}{ Silica gel } \\
\hline & $\begin{array}{l}\text { AVG } \\
(n=3)\end{array}$ & SD & $\begin{array}{l}\text { AVG } \\
(n=3)\end{array}$ & SD & $\begin{array}{l}\text { AVG } \\
(n=3)\end{array}$ & SD & $\begin{array}{l}\text { AVG } \\
(n=3)\end{array}$ & SD & $\begin{array}{l}\text { AVG } \\
(n=3)\end{array}$ & SD \\
\hline$N Q$ & 95 & 1.2 & $67 *$ & 1.2 & 84 & 9.7 & 98 & 1.0 & 116 & 4.9 \\
\hline NTO $(210 \mathrm{~nm})$ & $1,814 \dagger$ & 19.8 & $2,081 \dagger$ & 180.4 & $1,971 \dagger$ & 69.4 & $746+$ & 255.7 & $2,244 \dagger$ & 54.6 \\
\hline NTO (315nm) & 121 & 5.7 & 115 & 10.5 & 117 & 2.6 & 82 & 8.7 & $138+$ & 6.2 \\
\hline o-NBA (surrogate) & 86 & 15.9 & 89 & 12.8 & 76 & 7.3 & $146 \dagger$ & 17.0 & 78 & 5.5 \\
\hline HMX & 89 & 9.6 & 91 & 11.8 & 86 & 7.8 & 91 & 2.8 & 81 & 7.1 \\
\hline RDX & 76 & 33.7 & 96 & 3.2 & 96 & 3.0 & 107 & 7.4 & 99 & 0.1 \\
\hline$P A(210 n m)$ & $170 \dagger$ & 103.3 & $175+$ & 82.1 & $149+$ & 70.8 & 86 & 10.4 & 112 & 63.4 \\
\hline$P A(315 n m)$ & 93 & 6.9 & 84 & 16.9 & 80 & 9.7 & 87 & 23.2 & $67 *$ & 14.8 \\
\hline 4-NP & 113 & 27.3 & 92 & 9.2 & 90 & 0.7 & 101 & 0.7 & 89 & 10.4 \\
\hline $1,3,5-\mathrm{TNB}$ & 96 & 10.9 & 92 & 3.7 & 92 & 4.4 & 98 & 0.4 & 89 & 8.5 \\
\hline $2,4-D N P$ & 95 & 1.5 & 96 & 2.4 & 96 & 1.5 & 104 & 12.3 & 95 & 4.1 \\
\hline 1,2-DNB (surrogate) & 97 & 2.8 & 100 & 0.7 & 98 & 1.0 & 104 & 9.6 & 101 & 2.8 \\
\hline 1,3-DNB & 95 & 1.5 & 98 & 1.2 & 96 & 2.3 & 100 & 0.4 & 96 & 2.0 \\
\hline $2-N P$ & 101 & 14.4 & 91 & 3.1 & 91 & 1.5 & 85 & 3.7 & 88 & 3.6 \\
\hline NB & 99 & 2.0 & 98 & 6.4 & 98 & 3.0 & $131 *$ & 15.3 & 98 & 2.7 \\
\hline 3,5 -DNA $(210 \mathrm{~nm})$ & 97 & 14.3 & 94 & 4.4 & 88 & 3.0 & 100 & 0.6 & 90 & 4.4 \\
\hline $3,5-\mathrm{DNA}(254 \mathrm{~nm})$ & 94 & 2.6 & 96 & 1.6 & 94 & 2.2 & 112 & 5.5 & 94 & 2.6 \\
\hline$D N A N$ & 104 & 14.2 & 102 & 6.2 & 95 & 3.2 & 113 & 8.2 & 98 & 6.4 \\
\hline Tetryl & 89 & 13.0 & 103 & 11.4 & 106 & 4.2 & $58 \dagger$ & 2.7 & 104 & 6.1 \\
\hline $\mathrm{NG}$ & $70 *$ & 32.3 & 111 & 16.7 & 107 & 20.8 & $169+$ & 11.6 & 116 & 19.2 \\
\hline 2,4,6-TNT & 95 & 5.5 & 99 & 5.1 & 103 & 7.0 & 108 & 1.4 & 104 & 8.3 \\
\hline 4-Am-2,6-DNT & 104 & 10.5 & 98 & 5.0 & 97 & 1.6 & 104 & 7.8 & 95 & 0.9 \\
\hline 2-Am-4,6-DNT & 105 & 7.4 & 97 & 1.3 & 98 & 3.0 & 104 & 9.5 & 100 & 2.7 \\
\hline
\end{tabular}




\begin{tabular}{|c|c|c|c|c|c|c|c|c|c|c|}
\hline \multirow[b]{3}{*}{ Compound } & \multicolumn{10}{|c|}{ Earthworm-recoveries (\%) } \\
\hline & \multicolumn{2}{|c|}{ Neutral alumina } & \multicolumn{2}{|c|}{$\left.\right|_{\text {neutral alumina }} ^{\text {Florisil }}$} & \multicolumn{2}{|c|}{$\begin{array}{l}\text { Mixed neutral } \\
\text { alumina-florisil }\end{array}$} & \multicolumn{2}{|c|}{ Basic alumina } & \multicolumn{2}{|c|}{ Silica gel } \\
\hline & $\begin{array}{l}\text { AVG } \\
(n=3)\end{array}$ & SD & $\begin{array}{l}\text { AVG } \\
(n=3)\end{array}$ & SD & $\begin{array}{l}\text { AVG } \\
(n=3)\end{array}$ & SD & $\begin{array}{l}\text { AVG } \\
(n=3)\end{array}$ & SD & $\begin{array}{l}\text { AVG } \\
(n=3)\end{array}$ & SD \\
\hline 2,6-DNT & 96 & 8.9 & 90 & 2.5 & 93 & 6.7 & 102 & 2.4 & 85 & 1.0 \\
\hline 2,4-DNT & 99 & 4.8 & 99 & 3.2 & 96 & 3.6 & 101 & 1.1 & 97 & 2.9 \\
\hline 2-NT & 98 & 4.1 & 101 & 4.1 & 101 & 1.1 & 117 & 2.1 & 98 & 2.8 \\
\hline 4-NT & 97 & 2.9 & 104 & 9.7 & 94 & 5.9 & 99 & 4.6 & 100 & 0.8 \\
\hline 3-NT & 99 & 5.1 & 100 & 3.7 & 100 & 4.0 & 109 & 9.0 & 97 & 2.1 \\
\hline PETN & 99 & 1.4 & 89 & 5.4 & 89 & 6.5 & 95 & 2.0 & 95 & 6.4 \\
\hline
\end{tabular}

Bold, italicized are IM compounds and degradation products.

Green: $75 \%-125 \%$; light green $(*): 64 \%-74 \%$ or $126 \%-135 \%$; red $(\dagger):<64 \%$ or $>135 \%$ (DoD QSM Ver5.2 for Solids-lowest LCL: 4-Am-2,6-DNT, 64\%; highest UCL: Tetryl, 135\%) 
Table 22. Recoveries (\%) from postextraction spiked polychaete worm tissue $\mathrm{MeOH}$ extract, following five different chromatographic treatment options for matrix-related analytical interference reduction.

(AVG = average; $\mathrm{SD}=$ standard deviation)

\begin{tabular}{|c|c|c|c|c|c|c|c|c|c|c|}
\hline \multirow[b]{3}{*}{ Compound } & \multicolumn{10}{|c|}{ Polychaete worm-recoveries (\%) } \\
\hline & \multicolumn{2}{|c|}{ Neutral alumina } & \multicolumn{2}{|c|}{ neutral alumina } & \multicolumn{2}{|c|}{$\begin{array}{l}\text { Mixed neutral } \\
\text { alumina-florisil }\end{array}$} & \multicolumn{2}{|c|}{ Basic alumina } & \multicolumn{2}{|c|}{ Silica gel } \\
\hline & $\begin{array}{l}\text { AVG } \\
(n=3)\end{array}$ & SD & $\begin{array}{l}\text { AVG } \\
(n=3)\end{array}$ & SD & $\begin{array}{l}\text { AVG } \\
(n=3)\end{array}$ & SD & $\begin{array}{l}\text { AVG } \\
(n=3)\end{array}$ & SD & $\begin{array}{l}\text { AVG } \\
(n=3)\end{array}$ & SD \\
\hline$N Q$ & $140+$ & 100.4 & $183+$ & 123.6 & $72 *$ & 5.4 & 80 & 5.3 & 92 & 6.3 \\
\hline NTO (210nm) & $977+$ & 218.1 & $848 \dagger$ & 49.0 & $836 \dagger$ & 25.5 & $1,860+$ & 642.5 & 939† & 61.5 \\
\hline NTO (315nm) & $134 *$ & 2.1 & $132 *$ & 7.6 & $136+$ & 5.1 & $148+$ & 5.2 & $140+$ & 7.3 \\
\hline o-NBA (surrogate) & 102 & 2.0 & 100 & 0.7 & 102 & 3.6 & 105 & 6.2 & 98 & 6.8 \\
\hline HMX & 98 & 3.2 & 95 & 2.5 & 97 & 3.5 & 92 & 1.7 & 91 & 8.2 \\
\hline RDX & 99 & 3.7 & 101 & 3.1 & 100 & 3.5 & 95 & 1.8 & 95 & 6.7 \\
\hline$P A(210 n m)$ & 98 & 5.2 & 102 & 11.9 & 122 & 7.1 & 93 & 1.7 & 101 & 8.9 \\
\hline$P A(315 n m)$ & 98 & 1.3 & 99 & 0.7 & 99 & 2.4 & 95 & 6.6 & 94 & 7.3 \\
\hline 4-NP & 99 & 1.7 & 99 & 0.4 & 100 & 3.5 & 96 & 1.6 & 95 & 6.3 \\
\hline $1,3,5-\mathrm{TNB}$ & 97 & 2.8 & 96 & 1.5 & 107 & 16.0 & 93 & 2.0 & 94 & 8.3 \\
\hline $2,4-D N P$ & 98 & 3.9 & 97 & 2.3 & 90 & 9.5 & 94 & 1.9 & 99 & 8.0 \\
\hline 1,2-DNB (surrogate) & 104 & 3.9 & 102 & 1.5 & 92 & 9.4 & 97 & 2.3 & 101 & 7.9 \\
\hline 1,3-DNB & 99 & 1.1 & 99 & 2.2 & 100 & 3.4 & 97 & 5.1 & 96 & 8.0 \\
\hline $2-N P$ & 91 & 4.3 & 90 & 4.7 & 89 & 4.1 & 103 & 7.6 & 89 & 5.2 \\
\hline NB & 98 & 2.6 & 99 & 0.4 & 98 & 5.1 & 91 & 2.5 & 97 & 9.9 \\
\hline 3,5-DNA (210nm) & 96 & 7.9 & 100 & 5.5 & 99 & 8.7 & 108 & 0.1 & 90 & 9.1 \\
\hline 3,5-DNA (254nm) & 103 & 3.9 & 102 & 2.6 & 104 & 7.1 & 105 & 11.1 & 93 & 8.6 \\
\hline$D N A N$ & 98 & 9.3 & 100 & 6.5 & 92 & 1.4 & 91 & 4.8 & 94 & 8.6 \\
\hline Tetryl & 101 & 2.6 & 97 & 0.7 & 97 & 3.6 & 89 & 0.4 & 95 & 8.4 \\
\hline $\mathrm{NG}$ & 106 & 5.6 & 95 & 3.7 & 98 & 16.7 & 103 & 2.0 & 98 & 13.6 \\
\hline 2,4,6-TNT & 101 & 1.5 & 98 & 1.0 & 103 & 7.1 & 95 & 1.3 & 95 & 6.7 \\
\hline 4-Am-2,6-DNT & 99 & 2.7 & 98 & 5.5 & 101 & 9.5 & 91 & 1.6 & 93 & 9.2 \\
\hline 2-Am-4,6-DNT & 97 & 3.3 & 95 & 7.4 & 96 & 0.8 & 95 & 2.1 & 91 & 8.0 \\
\hline
\end{tabular}




\begin{tabular}{|c|c|c|c|c|c|c|c|c|c|c|}
\hline \multirow[b]{3}{*}{ Compound } & \multicolumn{10}{|c|}{ Polychaete worm-recoveries (\%) } \\
\hline & \multicolumn{2}{|c|}{ Neutral alumina } & \multicolumn{2}{|c|}{$\left.\right|_{\text {neutral alumina }} ^{\text {Florisil }}$} & \multicolumn{2}{|c|}{$\begin{array}{l}\text { Mixed neutral } \\
\text { alumina-florisil }\end{array}$} & \multicolumn{2}{|c|}{ Basic alumina } & \multicolumn{2}{|c|}{ Silica gel } \\
\hline & $\begin{array}{l}\text { AVG } \\
(n=3)\end{array}$ & SD & $\begin{array}{l}\text { AVG } \\
(n=3)\end{array}$ & SD & $\begin{array}{l}\text { AVG } \\
(n=3)\end{array}$ & SD & $\begin{array}{l}\text { AVG } \\
(n=3)\end{array}$ & SD & $\begin{array}{l}\text { AVG } \\
(n=3)\end{array}$ & SD \\
\hline 2,6-DNT & 97 & 2.4 & 100 & 3.9 & 96 & 4.3 & 105 & 6.0 & 103 & 15.2 \\
\hline 2,4-DNT & 99 & 3.3 & 94 & 3.4 & 99 & 5.5 & 94 & 2.9 & 96 & 7.3 \\
\hline 2-NT & 100 & 3.0 & 99 & 4.1 & 102 & 8.8 & 103 & 3.3 & 92 & 6.8 \\
\hline 4-NT & 99 & 1.4 & 96 & 9.5 & 99 & 1.1 & 94 & 0.9 & 93 & 6.8 \\
\hline $3-\mathrm{NT}$ & 106 & 4.7 & 104 & 4.2 & 106 & 5.3 & 101 & 1.8 & 96 & 8.6 \\
\hline PETN & 100 & 0.5 & 95 & 4.8 & 99 & 2.9 & 95 & 7.8 & 90 & 8.5 \\
\hline
\end{tabular}

Bold, italicized are IM compounds and degradation products.

Green: $75 \%-125 \%$; light green $(*): 64 \%-74 \%$ or $126 \%-135 \%$; red $(\dagger):<64 \%$ or $>135 \%$ (DoD QSM Ver5.2 for Solids-lowest LCL: 4-Am-2,6-DNT, 64\%; highest UCL: Tetryl, 135\%) 
Table 23. Recoveries (\%) from postextraction spiked ryegrass tissue $\mathrm{MeOH}$ extract, following five different chromatographic treatment options for matrix-related analytical interference reduction. (AVG = average; SD = standard deviation)

\begin{tabular}{|c|c|c|c|c|c|c|c|c|c|c|}
\hline \multirow[b]{3}{*}{ Compound } & \multicolumn{10}{|c|}{ Ryegrass-recoveries (\%) } \\
\hline & \multicolumn{2}{|c|}{ Neutral alumina } & \multicolumn{2}{|c|}{ neutral alumina } & \multicolumn{2}{|c|}{$\begin{array}{l}\text { Mixed neutral } \\
\text { alumina-florisil }\end{array}$} & \multicolumn{2}{|c|}{ Basic alumina } & \multicolumn{2}{|c|}{ Silica gel } \\
\hline & $\begin{array}{l}\text { AVG } \\
(n=3)\end{array}$ & SD & $\begin{array}{l}\text { AVG } \\
(n=3)\end{array}$ & SD & $\begin{array}{l}\text { AVG } \\
(n=3)\end{array}$ & SD & $\begin{array}{l}\text { AVG } \\
(n=3)\end{array}$ & SD & $\begin{array}{l}\text { AVG } \\
(n=3)\end{array}$ & SD \\
\hline$N Q$ & 97 & 4.7 & 82 & 7.6 & 88 & 0.7 & 100 & 3.5 & 90 & 7.0 \\
\hline NTO (210nm) & $573+$ & 147.7 & $576 \dagger$ & 63.6 & $500 \dagger$ & 45.4 & $1,081 \dagger$ & $1,272.6$ & $595 \dagger$ & 29.7 \\
\hline NTO $(315 \mathrm{~nm})$ & 114 & 3.2 & 112 & 3.0 & 113 & 3.9 & $174 \dagger$ & 146.1 & $130 *$ & 4.9 \\
\hline o-NBA (surrogate) & $138+$ & 29.6 & $127 *$ & 15.0 & $171+$ & 6.3 & 107 & 8.4 & $146 \dagger$ & 8.0 \\
\hline HMX & 98 & 2.7 & 93 & 5.5 & 101 & 4.0 & 99 & 5.0 & 96 & 9.9 \\
\hline RDX & 100 & 5.2 & 100 & 2.7 & 101 & 3.1 & 101 & 2.9 & 99 & 2.8 \\
\hline$P A(210 n m)$ & 96 & 12.1 & 84 & 3.1 & 101 & 2.8 & 90 & 15.6 & 96 & 5.4 \\
\hline$P A(315 n m)$ & 100 & 3.5 & 101 & 1.8 & 101 & 2.5 & 87 & 12.5 & 93 & 3.4 \\
\hline 4-NP & 101 & 1.0 & 100 & 3.1 & 98 & 1.8 & 98 & 4.2 & 96 & 3.9 \\
\hline $1,3,5-\mathrm{TNB}$ & 99 & 3.6 & 100 & 6.1 & 98 & 2.7 & 96 & 3.4 & 96 & 5.8 \\
\hline $2,4-D N P$ & 98 & 2.4 & 106 & 10.8 & 104 & 4.3 & 95 & 6.1 & 96 & 4.8 \\
\hline 1,2-DNB (surrogate) & 108 & 1.3 & 112 & 5.8 & 106 & 2.4 & 104 & 1.7 & 103 & 9.3 \\
\hline 1,3-DNB & 100 & 2.4 & 101 & 1.4 & 99 & 2.1 & 99 & 2.1 & 97 & 4.2 \\
\hline $2-N P$ & 92 & 4.2 & 84 & 3.6 & 95 & 4.7 & 84 & 15.1 & 88 & 4.1 \\
\hline $\mathrm{NB}$ & 103 & 1.4 & 103 & 4.0 & 100 & 0.5 & 97 & 3.9 & 103 & 2.6 \\
\hline 3,5-DNA (210nm) & 101 & 2.9 & 113 & 6.2 & 96 & 1.2 & 98 & 20.6 & 97 & 4.0 \\
\hline 3,5-DNA (254nm) & 101 & 1.4 & 103 & 3.3 & 97 & 4.1 & 99 & 25.7 & 94 & 1.6 \\
\hline$D N A N$ & 102 & 4.7 & 115 & 7.3 & 96 & 1.9 & 92 & 5.0 & 100 & 3.7 \\
\hline Tetryl & 100 & 3.6 & 97 & 3.6 & 94 & 2.8 & 95 & 8.4 & 96 & 7.5 \\
\hline $\mathrm{NG}$ & 109 & 8.3 & 100 & 2.1 & 94 & 2.4 & 109 & 7.3 & 86 & 13.3 \\
\hline $2,4,6-\mathrm{TNT}$ & 110 & 8.2 & 105 & 8.5 & 98 & 4.1 & 100 & 2.8 & 97 & 3.3 \\
\hline 4-Am-2,6-DNT & 98 & 1.7 & 99 & 3.7 & 98 & 2.6 & 96 & 5.4 & 104 & 9.9 \\
\hline 2-Am-4,6-DNT & 98 & 0.4 & 100 & 6.0 & 97 & 2.6 & 99 & 2.0 & 95 & 6.1 \\
\hline
\end{tabular}




\begin{tabular}{|c|c|c|c|c|c|c|c|c|c|c|}
\hline \multirow[b]{3}{*}{ Compound } & \multicolumn{10}{|c|}{ Ryegrass-recoveries (\%) } \\
\hline & \multicolumn{2}{|c|}{ Neutral alumina } & \multicolumn{2}{|c|}{$\left.\right|_{\text {neutral alumina }} ^{\text {Florisil }}$} & \multicolumn{2}{|c|}{$\begin{array}{l}\text { Mixed neutral } \\
\text { alumina-florisil }\end{array}$} & \multicolumn{2}{|c|}{ Basic alumina } & \multicolumn{2}{|c|}{ Silica gel } \\
\hline & $\begin{array}{l}\text { AVG } \\
(n=3)\end{array}$ & SD & $\begin{array}{l}\text { AVG } \\
(n=3)\end{array}$ & SD & $\begin{array}{l}\text { AVG } \\
(n=3)\end{array}$ & SD & $\begin{array}{l}\text { AVG } \\
(n=3)\end{array}$ & SD & $\begin{array}{l}\text { AVG } \\
(n=3)\end{array}$ & SD \\
\hline 2,6-DNT & 98 & 3.1 & 97 & 8.2 & 96 & 2.0 & 93 & 9.8 & 108 & 8.5 \\
\hline 2,4-DNT & 98 & 2.0 & 101 & 1.7 & 101 & 5.5 & 99 & 2.3 & 95 & 3.8 \\
\hline 2-NT & 99 & 3.0 & 101 & 5.7 & 102 & 3.3 & 93 & 23.3 & 97 & 2.6 \\
\hline 4-NT & 101 & 0.3 & 99 & 1.1 & 99 & 4.2 & 97 & 7.3 & 96 & 2.7 \\
\hline $3-\mathrm{NT}$ & 107 & 6.1 & 98 & 7.1 & 99 & 9.8 & 92 & 16.4 & 95 & 7.0 \\
\hline PETN & 100 & 2.3 & 97 & 3.8 & 101 & 5.4 & 107 & 7.3 & 99 & 1.1 \\
\hline
\end{tabular}

Bold, italicized are IM compounds and degradation products.

Green: $75 \%-125 \%$; light green $(*): 64 \%-74 \%$ or $126 \%-135 \%$; red $(\dagger):<64 \%$ or $>135 \%$ (DoD QSM Ver5.2 for Solids-lowest LCL: 4-Am-2,6-DNT, 64\%; highest UCL: Tetryl, 135\%) 
During method development for tissue matrix-related interference reduction, comparative analysis of NTO and of PA using detection wavelengths of $210 \mathrm{~nm}$ and $315 \mathrm{~nm}$ showed that much of the analytical interferences observed at $210 \mathrm{~nm}$ were absent at $315 \mathrm{~nm}$; therefore, use of $315 \mathrm{~nm}$ was preferred for determinations of NTO and PA in tissue extracts. A detection wavelength of $315 \mathrm{~nm}$ may also be preferred for NTO and PA in water and soil matrices as a measure to combat the contribution of interferent compounds in munition compound determinations. In addition, lower MDLs were obtained for both NTO and PA in water and soil by detecting at $315 \mathrm{~nm}$ rather than $210 \mathrm{~nm}$ (Table 6, section 3.1).

Finally, pre-extraction spiked tissue sample $\mathrm{MeOH}$ extracts were treated with the silica gel interference reduction option. Overall, the results (Table 24) showed that using a single $18 \mathrm{~h} \mathrm{MeOH}$ extraction in combination with silica gel treatment proved sufficient to yield recoveries for most compounds within current DoD QSM limits. The only compound recovered poorly from all four tissue matrices was Tetryl, with the highest recovery obtained for plant tissue, which again may point to the matrixdependent stability of this compound. The silica gel treatment removed or reduced the majority of interferences previously observed for each tissue type. Nontarget chromatographic peaks remained in the chromatographic region surrounding NTO, $o$-NBA surrogate, and 1,3,5-TNB (for earthworm). Of these remaining observed interferences, only the $1,3,5^{-}$ TNB determination was affected. For polychaete worm, the $1,3,5$-TNB and 4-Am-2,6-DNT recoveries were somewhat low but had been shown in previous experiments to be recovered within QSM Ver5.2 accepted limits. Therefore, $18 \mathrm{~h} \mathrm{MeOH}$ extraction in combination with silica gel chromatographic treatment for interference reduction was selected for future work. 
Table 24. Recoveries (\%) from pre-extraction spiked tissue $\mathrm{MeOH}$ extracts, following chromatographic treatment with silica gel for matrix-related analytical interference reduction. (AVG = average; SD = standard deviation)

\begin{tabular}{|c|c|c|c|c|}
\hline \multirow[b]{2}{*}{ Compound } & \multicolumn{4}{|c|}{ Recoveries (\%) } \\
\hline & Fathead minnow & Polychaete worm & Earthworm & Ryegrass \\
\hline$N Q$ & 113 & $73^{\star}$ & 86 & $68^{\star}$ \\
\hline NTO $(210 \mathrm{~nm})$ & $8,477 \dagger$ & $5,318+$ & $4,503+$ & $149+$ \\
\hline NTO $(315 \mathrm{~nm})$ & 87 & 113 & 98 & $133^{\star}$ \\
\hline o-NBA (surrogate) & 101 & 82 & 111 & $67 *$ \\
\hline $\mathrm{HMX}$ & 81 & $66 *$ & 79 & 99 \\
\hline RDX & 86 & $66 *$ & 93 & 85 \\
\hline$P A(210 \mathrm{~nm})$ & 79 & $73^{\star}$ & $37 t$ & 79 \\
\hline$P A(315 \mathrm{~nm})$ & $66^{\star}$ & $66^{*}$ & $68^{\star}$ & $71^{*}$ \\
\hline 4-NP & 83 & $71^{*}$ & $72^{\star}$ & 84 \\
\hline 1,3,5-TNB & 84 & $52 \dagger$ & $3,670 \dagger$ & 83 \\
\hline 2,4-DNP & 110 & $72^{\star}$ & 81 & 93 \\
\hline 1,2-DNB (surrogate) & 93 & $72 *$ & 82 & $73 *$ \\
\hline 1,3-DNB & 76 & $65 v$ & $65 *$ & 86 \\
\hline $2-N P$ & 105 & 81 & $74^{*}$ & 94 \\
\hline NB & 84 & 94 & 83 & 90 \\
\hline 3,5-DNA $(210 \mathrm{~nm})$ & $183+$ & $139+$ & $73 *$ & 90 \\
\hline 3,5-DNA $(254 \mathrm{~nm})$ & $69 *$ & $75 *$ & 80 & $73 *$ \\
\hline DNAN & 123 & $72^{\star}$ & 86 & 76 \\
\hline Tetryl & $16 \dagger$ & $6+$ & $4 \dagger$ & $62 \dagger$ \\
\hline$N G$ & 116 & $132 *$ & 87 & 125 \\
\hline 2,4,6-TNT & 119 & 100 & 80 & 80 \\
\hline 4-Am-2,6-DNT & 78 & $57 \dagger$ & $74 *$ & 88 \\
\hline 2-Am-4,6-DNT & 102 & $67 *$ & 88 & 85 \\
\hline 2,6-DNT & 110 & $71 *$ & 79 & 85 \\
\hline 2,4-DNT & 108 & $67 *$ & $69 *$ & 88 \\
\hline 2-NT & $129 *$ & 101 & $68 *$ & 89 \\
\hline 4-NT & 95 & $73 *$ & $69 *$ & 80 \\
\hline 3-NT & $64 *$ & $64 *$ & $68 *$ & 86 \\
\hline PETN & 109 & $74 *$ & $67 *$ & 91 \\
\hline
\end{tabular}

Bold, italicized are IM compounds and degradation products.

Green: $75 \%-125 \%$; light green (*): $64 \%-74 \%$ or $126 \%-135 \%$; red $(\dagger):<64 \%$ or $>135 \%$

(DoD QSM Ver5.2 for Solids-lowest LCL: 4-Am-2,6-DNT, 64\%; highest UCL: Tetryl, 135\%) 


\subsection{Stability study}

Extraction and analysis hold-time studies were carried out in reagent water (direct injection and SPE) and three soils (Riley, Yuma, and ASTM fat clay, described in Table 14) spiked with the 17 legacy and 7 IM compounds of interest and two surrogates. Currently accepted preextraction hold times are 7 days for waters and 14 days for solid matrices, and postextraction hold time for analysis is 40 days for samples analyzed by USEPA Method 8330 B, which references USEPA SW-846 section 4.1 guidelines for semi-volatile organics (USEPA 2014). As these hold times were adopted for methods including only legacy munition compounds, experiments were carried out to test whether the limits would also be appropriate for the seven compounds of interest and $o$-NBA surrogate added under SERDP-ER2722. Soils with varying physicochemical properties were tested in order to observe any potential matrix-related variability.

Results for the pre-extraction hold-time experiments for water are shown in Table 25. For direct-injection water samples, the majority of compounds were recovered within current DoD QSM limits on Day o and Day 7, so most compounds were stable under all three storage conditions for at least seven days. However, NTO recovery was $<57 \%$ on Day 7 for samples stored at room temperature in clear containers. For unknown reasons, NTO determinations were generally very high in this study, possibly suffering from analytical interference not observed elsewhere in the current project. Still, the recoveries for NTO stored at room temperature in clear containers were extremely low compared to those for samples stored under the other two conditions. Therefore, NTO determinations in samples stored in light for extended periods might not be reliable.

In general, SPE option B proved more effective at NQ recovery than option A, and option B was selected during SPE method finalization. Apart from possible NTO instability, only NQ showed possible instability at room temperature. NQ recoveries were lower for room temperature than for cold samples and were lower in samples stored in clear containers than those stored in amber containers. Thus, NQ determinations in samples stored at room temperature (especially in light) for extended periods might not be reliable.

Results for the postextraction hold-time experiments for water are shown in Table 26. Again, for unknown reasons, NTO determinations were 
generally very high in this study, possibly due to analytical interference. Overall, though, NTO recoveries decreased from Day o to Day 40, and were lower in room temperature samples, especially those stored in clear containers. However, all of the NTO recoveries were nominally within current DoD QSM limits. Therefore, determination of NTO might be affected by possible instability issues.

On the other hand, NQ determinations in SPE samples differed significantly depending on the SPE cartridge option used to extract and preconcentrate the water sample. For SPE option A, recoveries for NQ were much higher (about 100\%) in Day 40 samples, whereas the average recovery on Day o was very low (19\%). There could be a positive analytical interferent, such as a degradation product, accumulating over the course of the 40-day storage period and enhancing the NQ recovery determination. Alternately, for SPE option B, recoveries for NQ were fairly stable over the 40-day period.

In addition, instability of the three NTs was observed in direct-injection samples and SPE samples, with recoveries for each of them generally decreasing with increased temperature and light exposure. Recoveries of these compounds were within current DoD QSM limits for Day 40 samples stored in cold temperatures, indicating that the instability could be reduced by avoiding elevated temperatures and keeping with current recommendations to store at $\leq 4^{\circ} \mathrm{C}$.

Results for the pre-extraction hold-time experiments for soil are shown in Table 27. For unknown reasons, in the Day o soil samples, a few compounds were recovered at lower than usual levels, especially for the Riley field soil. In addition, NTO, HMX, and RDX recoveries were recovered at levels below current limits $(<64 \%)$ at Day 14 . This lower recovery was observed for two of the soils for HMX and RDX, and for all three soils for NTO, indicating that pre-extraction holding-time limits might need shortening for soils where these compounds are known or suspected to be present. Overall, though, the majority of compounds were recovered within current DoD QSM limits at both Day o and Day 14, including all other IM compounds tested.

Results for the postextraction hold-time experiments for soil are shown in Table 28. Again, for unknown reasons, NTO determinations were 
generally very high in this study, possibly because of analytical interference. 
Table 25. Extraction hold-time stability for laboratory-spiked reagent water samples over seven days. (AVG = average; SD = standard deviation)

\begin{tabular}{|c|c|c|c|c|c|c|c|c|c|c|c|c|c|c|c|c|c|c|c|c|c|c|c|c|}
\hline \multirow[b]{5}{*}{ Compound } & \multicolumn{24}{|c|}{ Recoveries (\%) } \\
\hline & \multirow{2}{*}{\multicolumn{6}{|c|}{ Waters Day 0 extraction and analysis }} & \multicolumn{18}{|c|}{ Waters Day 7 extraction and analysis } \\
\hline & & & & & & & \multicolumn{6}{|c|}{ Cold/Dark } & \multicolumn{6}{|c|}{ Room temperature / Dark } & \multicolumn{6}{|c|}{ Room temperature / Light } \\
\hline & \multicolumn{2}{|c|}{ SPE A (evap) } & \multicolumn{2}{|c|}{ SPE B (evap) } & \multicolumn{2}{|c|}{ Direct injection } & \multicolumn{2}{|c|}{ SPE A (no evap) } & \multicolumn{2}{|c|}{ SPE B (no evap) } & \multicolumn{2}{|c|}{ Direct injection } & \multicolumn{2}{|c|}{ SPE A (no evap) } & \multicolumn{2}{|c|}{ SPE B (no evap) } & \multicolumn{2}{|c|}{ Direct injection } & \multicolumn{2}{|c|}{ SPE A (no evap) } & \multicolumn{2}{|c|}{ SPE B (no evap) } & \multicolumn{2}{|c|}{ Direct injection } \\
\hline & $\begin{array}{l}\mathrm{AVG} \\
(n=3)\end{array}$ & SD & $\begin{array}{l}\text { AVG } \\
(n=3)\end{array}$ & SD & $\begin{array}{l}\text { AVG } \\
(n=3) \\
\end{array}$ & SD & $\begin{array}{l}\text { AVG } \\
(n=3)\end{array}$ & SD & $\begin{array}{l}\text { AVG } \\
(n=3)\end{array}$ & SD & $\begin{array}{l}\text { AVG } \\
(n=3)\end{array}$ & SD & $\begin{array}{l}\text { AVG } \\
(n=3)\end{array}$ & SD & $\begin{array}{l}\mathrm{AVG} \\
(n=3)\end{array}$ & SD & $\begin{array}{l}\text { AVG } \\
(n=3)\end{array}$ & SD & $\begin{array}{l}\text { AVG } \\
(n=3)\end{array}$ & SD & $\begin{array}{l}\text { AVG } \\
(n=3)\end{array}$ & SD & $\begin{array}{l}\text { AVG } \\
(n=3)\end{array}$ & SD \\
\hline$N Q$ & $19+$ & 1.4 & $42+$ & 1.9 & 74 & 13.6 & $14 \dagger$ & 2.9 & $34 \dagger$ & 4.3 & 75 & 20.8 & $15+$ & 2.1 & $26+$ & 1.1 & 88 & 9.8 & $15+$ & 0.7 & $21 \dagger$ & 6.4 & 80 & 9.9 \\
\hline NTO $(210 \mathrm{~nm})$ & $261 \dagger$ & 2.5 & $286+$ & 14.1 & $138+$ & 2.8 & $305+$ & 37.8 & $311 \dagger$ & 4.2 & 79 & 19.2 & $293+$ & 17.7 & $303+$ & 6.3 & 80 & 3.8 & $300+$ & 11.7 & $229+$ & 62.9 & $29+$ & 22.9 \\
\hline NTO $(315 \mathrm{~nm})$ & $270+$ & 2.4 & $292 \dagger$ & 15.2 & 99 & 14.2 & $306+$ & 40.9 & $307 \dagger$ & 2.4 & 78 & 25.0 & $291 \dagger$ & 16.4 & $299+$ & 2.3 & $68^{*}$ & 17.1 & $300+$ & 9.9 & $227 \dagger$ & 66.6 & $53+$ & 8.9 \\
\hline o-NBA (surrogate) & 107 & 0.9 & 112 & 7.0 & 106 & 10.6 & 106 & 16.1 & 104 & 4.7 & 100 & 23.0 & 99 & 5.3 & 99 & 2.1 & 101 & 4.2 & 103 & 3.4 & $66^{*}$ & 30.3 & 107 & 1.8 \\
\hline HMX & 91 & 0.8 & 98 & 5.1 & 88 & 9.6 & 104 & 10.2 & 108 & 2.3 & 95 & 0.6 & 100 & 3.9 & 104 & 0.7 & 100 & 4.7 & 104 & 3.2 & 103 & 10.5 & 99 & 1.5 \\
\hline $\mathrm{RDX}$ & 77 & 4.3 & 88 & 7.8 & $68^{*}$ & 10.3 & 93 & 20.9 & 102 & 2.4 & 91 & 3.1 & 78 & 19.0 & 101 & 3.3 & 90 & 0.3 & 96 & 0.7 & 95 & 14.4 & 116 & 10.0 \\
\hline PA (210nm) & 81 & 1.5 & 93 & 5.4 & 84 & 5.8 & 101 & 21.7 & 111 & 0.3 & 97 & 5.6 & 88 & 21.6 & 107 & 5.4 & 116 & 6.5 & 104 & 3.5 & 101 & 17.0 & $125^{\star}$ & 15.8 \\
\hline$P A(315 n m)$ & 93 & 1.1 & 100 & 5.4 & 83 & 4.9 & 107 & 6.9 & 109 & 0.9 & 97 & 0.3 & 101 & 6.0 & 107 & 2.1 & 103 & 7.6 & 108 & 1.8 & 106 & 9.1 & 96 & 0.5 \\
\hline 4-NP & 90 & 0.8 & 97 & 5.0 & 92 & 6.3 & 110 & 7.0 & 114 & 1.0 & 109 & 1.0 & 105 & 6.4 & 111 & 0.3 & 105 & 5.2 & 110 & 4.4 & 111 & 10.4 & 112 & 1.6 \\
\hline 1,3,5-TNB & 89 & 1.3 & 95 & 4.9 & 87 & 7.0 & 104 & 6.5 & 105 & 1.2 & 102 & 1.2 & 99 & 6.1 & 102 & 0.8 & 104 & 1.0 & 105 & 2.8 & 102 & 9.9 & 107 & 7.3 \\
\hline 2,4-DNP & 85 & 0.6 & 90 & 4.3 & 96 & 2.5 & 106 & 18.7 & 114 & 0.8 & 119 & 7.9 & 95 & 19.5 & 112 & 0.7 & $136+$ & 4.7 & 110 & 5.3 & 112 & 12.4 & $125^{\star}$ & 5.7 \\
\hline 1,2-DNB (surrogate) & 87 & 0.8 & 79 & 7.0 & 97 & 5.3 & 114 & 8.9 & 115 & 3.6 & 116 & 10.3 & 109 & 5.4 & 113 & 1.6 & 115 & 3.7 & 115 & 2.5 & 113 & 11.4 & 116 & 7.0 \\
\hline 1,3-DNB & 84 & 0.8 & 77 & 6.7 & 87 & 6.2 & 104 & 5.6 & 106 & 1.0 & 104 & 3.1 & 100 & 5.5 & 104 & 1.6 & 104 & 1.7 & 105 & 2.1 & 98 & 16.8 & 106 & 1.0 \\
\hline $2-N P$ & $5+$ & 3.0 & $0+$ & 0.0 & 87 & 0.8 & 88 & 5.9 & 93 & 1.9 & 87 & 5.6 & 82 & 5.5 & 89 & 0.6 & 92 & 5.7 & 81 & 13.2 & 87 & 12.8 & 98 & 3.0 \\
\hline NB & 90 & 2.3 & 97 & 7.9 & 79 & 9.7 & 104 & 7.1 & 106 & 0.6 & 106 & 5.1 & 98 & 6.1 & 104 & 0.2 & 108 & 6.0 & 104 & 1.3 & 102 & 10.9 & 107 & 4.8 \\
\hline 3,5-DNA (210nm) & $1+$ & 1.1 & $0+$ & 0.0 & 88 & 9.4 & 93 & 8.0 & 101 & 1.4 & 107 & 12.2 & 81 & 0.1 & 98 & 1.9 & 101 & 6.7 & 91 & 3.5 & 93 & 16.2 & 109 & 2.0 \\
\hline 3,5-DNA $(254 \mathrm{~nm})$ & $1 \dagger$ & 0.8 & $0+$ & 0.0 & 87 & 10.8 & 93 & 7.5 & 102 & 2.2 & 98 & 3.6 & 86 & 5.3 & 99 & 1.6 & 96 & 2.0 & 93 & 4.4 & 93 & 16.3 & 97 & 3.5 \\
\hline DNAN & 88 & 0.5 & 92 & 6.5 & $72^{\star}$ & 5.4 & 98 & 5.2 & 98 & 1.4 & 109 & 0.1 & 92 & 6.3 & 96 & 1.7 & 100 & 2.5 & 97 & 3.1 & 89 & 22.0 & 113 & 14.8 \\
\hline Tetryl & 89 & 1.8 & 95 & 4.6 & 86 & 16.1 & 100 & 5.7 & 103 & 1.0 & 96 & 8.0 & 95 & 5.5 & 100 & 0.7 & 86 & 6.7 & 101 & 0.3 & 97 & 9.3 & 75 & 16.2 \\
\hline$N G$ & 86 & 0.6 & 85 & 5.9 & $39+$ & 10.3 & 97 & 5.7 & 97 & 1.0 & 93 & 10.5 & 91 & 4.8 & 95 & 3.2 & 92 & 4.4 & 99 & 3.3 & 98 & 8.8 & 89 & 11.4 \\
\hline 2,4,6-TNT & 87 & 0.9 & 91 & 5.5 & $60 *$ & 12.2 & 103 & 6.2 & 103 & 1.8 & 101 & 2.2 & 98 & 5.8 & 100 & 1.7 & 96 & 5.3 & 100 & 7.6 & 98 & 16.5 & 99 & 3.9 \\
\hline 4-Am-2,6-DNT & 90 & 0.2 & 97 & 4.9 & 85 & 8.0 & 101 & 7.8 & 106 & 1.0 & 104 & 10.7 & 97 & 6.6 & 102 & 0.3 & 110 & 2.7 & 102 & 0.9 & 101 & 11.1 & 102 & 3.8 \\
\hline 2-Am-4,6-DNT & 92 & 2.4 & 99 & 4.9 & 88 & 6.9 & 101 & 6.6 & 105 & 1.6 & 108 & 15.4 & 97 & 6.5 & 102 & 1.7 & 109 & 2.8 & 105 & 3.9 & 99 & 15.4 & 106 & 8.6 \\
\hline 2,6-DNT & 74* & 2.6 & $38+$ & 10.0 & 100 & 11.8 & 96 & 4.8 & 96 & 1.8 & $68^{*}$ & 6.4 & 92 & 6.3 & 95 & 1.5 & $71^{*}$ & 1.6 & 96 & 2.0 & 86 & 20.5 & 81 & 7.4 \\
\hline 2,4-DNT & 84 & 0.8 & $70 *$ & 7.2 & 91 & 13.5 & 100 & 6.6 & 99 & 1.9 & 78 & 7.5 & 94 & 6.4 & 96 & 3.2 & $69 *$ & 13.4 & 99 & 1.2 & 81 & 28.0 & 77 & 4.3 \\
\hline 2-NT & $1 \dagger$ & 0.5 & $1 \dagger$ & 0.0 & $65^{*}$ & 19.5 & 86 & 8.5 & 96 & 2.6 & 81 & 17.8 & 78 & 4.5 & 93 & 1.1 & 84 & 6.7 & 84 & 5.9 & 84 & 21.1 & 94 & 13.7 \\
\hline 4-NT & $4 t$ & 1.8 & $1 \dagger$ & 0.3 & 88 & 9.9 & 92 & 6.4 & 100 & 4.8 & 99 & 5.5 & 88 & 6.7 & 95 & 3.3 & 94 & 11.7 & 92 & 4.5 & 82 & 26.8 & 93 & 18.3 \\
\hline 3-NT & $2+$ & 1.3 & $1 \dagger$ & 0.1 & $75^{*}$ & 11.7 & 91 & 7.6 & 103 & 2.3 & 92 & 10.2 & 86 & 5.8 & 99 & 3.2 & 96 & 1.7 & 91 & 4.4 & 86 & 27.0 & 98 & 3.8 \\
\hline PETN & 92 & 1.4 & 88 & 14.7 & $73^{*}$ & 12.8 & 103 & 7.4 & 107 & 0.8 & 108 & 24.7 & 98 & 7.9 & 102 & 5.7 & 101 & 8.3 & 104 & 2.0 & 103 & 12.9 & 107 & 3.0 \\
\hline
\end{tabular}


Table 26. Analysis hold-time stability for laboratory-spiked reagent water samples over 40 days. (AVG = average; $S D=$ standard deviation)

\begin{tabular}{|c|c|c|c|c|c|c|c|c|c|c|c|c|c|c|c|c|c|c|c|c|c|c|c|c|c|c|c|c|}
\hline \multirow[b]{5}{*}{ Compound } & \multicolumn{28}{|c|}{ Recoveries (\%) } \\
\hline & \multirow{2}{*}{\multicolumn{6}{|c|}{ Waters Day 0 extraction and analysis }} & \multicolumn{22}{|c|}{ Waters Day 0 extraction, Day 40 analysis } \\
\hline & & & & & & & \multicolumn{10}{|c|}{ Cold/Dark } & \multicolumn{6}{|c|}{ Room temperature / Dark } & \multicolumn{6}{|c|}{ Room temperature / Light } \\
\hline & \multicolumn{2}{|c|}{ SPE A (evap) } & \multicolumn{2}{|c|}{ SPE B (evap) } & \multicolumn{2}{|c|}{$\begin{array}{l}\text { Direct } \\
\text { injection }\end{array}$} & \multicolumn{2}{|c|}{ SPE A (evap) } & \multicolumn{2}{|c|}{$\begin{array}{l}\text { SPE A } \\
\text { (no evap) }\end{array}$} & \multicolumn{2}{|c|}{ SPE B (evap) } & \multicolumn{2}{|c|}{\begin{tabular}{|l|} 
SPE B \\
(no evap)
\end{tabular}} & \multicolumn{2}{|c|}{$\begin{array}{l}\text { Direct } \\
\text { injection }\end{array}$} & \multicolumn{2}{|c|}{ SPE A (evap) } & \multicolumn{2}{|c|}{ SPE B (evap) } & \multicolumn{2}{|c|}{$\begin{array}{l}\text { Direct } \\
\text { injection }\end{array}$} & SPEA & (evap) & SPE B & (evap) & $\begin{array}{l}\text { Direct } \\
\text { injectic }\end{array}$ & \\
\hline & $\begin{array}{l}\text { AVG } \\
(n=3)\end{array}$ & SD & $\begin{array}{l}\text { AVG } \\
(n=3)\end{array}$ & SD & $\begin{array}{l}\text { AVG } \\
(n=3)\end{array}$ & SD & \begin{tabular}{|l|} 
AVG \\
$(n=3)$
\end{tabular} & SD & $\begin{array}{l}\text { AVG } \\
(n=3)\end{array}$ & SD & $\begin{array}{l}\text { AVG } \\
(n=3)\end{array}$ & SD & \begin{tabular}{|l|} 
AVG \\
$(n=3)$
\end{tabular} & SD & $\begin{array}{l}\text { AVG } \\
(n=3)\end{array}$ & SD & \begin{tabular}{|l|} 
AVG \\
$(n=3)$
\end{tabular} & SD & $\begin{array}{l}\text { AVG } \\
(n=3)\end{array}$ & SD & \begin{tabular}{|l|} 
AVG \\
$(n=3)$
\end{tabular} & SD & $\begin{array}{l}\text { AVG } \\
(n=3)\end{array}$ & SD & $\begin{array}{l}\text { AVG } \\
(n=3)\end{array}$ & SD & $\begin{array}{l}\text { AVG } \\
(n=3)\end{array}$ & SD \\
\hline$N Q$ & $19+$ & 1.4 & $42+$ & 1.9 & $74^{\star}$ & 13.6 & 102 & 16.8 & $17 \dagger$ & 2.9 & $37 \dagger$ & 5.0 & $38+$ & 1.7 & 89 & 20.0 & 100 & 14.3 & $42+$ & 4.1 & 83 & 12.9 & 98 & 21.0 & $39+$ & 4.5 & 77 & 3.9 \\
\hline NTO $(210 \mathrm{~nm})$ & $261+$ & 2.5 & $286+$ & 14.1 & $138+$ & 2.8 & $126^{*}$ & 2.0 & 123 & 1.2 & $134^{\star}$ & 5.1 & $134^{\star}$ & 9.0 & $136+$ & 3.3 & $128^{*}$ & 2.3 & $142 \dagger$ & 0.0 & $136+$ & 3.3 & $127^{*}$ & 2.9 & $139+$ & 3.2 & 120 & 2.7 \\
\hline NTO $(315 \mathrm{~nm})$ & $270+$ & 2.4 & $292+$ & 15.2 & 99 & 14.2 & $128^{*}$ & 2.6 & 123 & 0.8 & $133^{*}$ & 4.9 & $131^{*}$ & 9.0 & $130^{*}$ & 4.5 & $130^{*}$ & 3.0 & $142+$ & 0.0 & $131^{\star}$ & 3.1 & $128^{*}$ & 3.2 & $140+$ & 3.0 & $126^{*}$ & 1.2 \\
\hline o-NBA (surrogate) & 107 & 0.9 & 112 & 7.0 & 106 & 10.6 & 109 & 1.1 & 111 & 1.9 & 112 & 1.5 & 118 & 4.9 & 117 & 4.6 & 106 & 0.5 & 109 & 5.1 & 117 & 5.9 & 105 & 3.3 & 108 & 4.3 & 118 & 1.4 \\
\hline HMX & 91 & 0.8 & 98 & 5.1 & 88 & 9.6 & 81 & 30.6 & 108 & 0.8 & 117 & 4.3 & 116 & 7.8 & 96 & 2.4 & 113 & 2.4 & 125 & 1.9 & 99 & 2.4 & 112 & 2.7 & 123 & 2.6 & 98 & 3.1 \\
\hline RDX & 77 & 4.3 & 88 & 7.8 & $68^{*}$ & 10.3 & 116 & 2.4 & 113 & 1.7 & 120 & 4.7 & 120 & 8.4 & 106 & 3.3 & 118 & 2.7 & $127^{*}$ & 2.4 & 107 & 5.4 & 117 & 3.3 & $126^{*}$ & 2.6 & 105 & 3.5 \\
\hline PA (210nm) & 81 & 1.5 & 93 & 5.4 & 84 & 5.8 & 88 & 2.1 & 81 & 1.6 & 93 & 5.0 & 88 & 1.7 & 114 & 10.6 & 89 & 1.1 & 99 & 2.0 & 111 & 4.0 & 88 & 2.2 & 99 & 2.1 & $139+$ & 7.0 \\
\hline$P A(315 \mathrm{~nm})$ & 93 & 1.1 & 100 & 5.4 & 83 & 4.9 & 94 & 1.6 & 83 & 1.5 & 102 & 1.6 & 92 & 2.6 & 97 & 3.1 & 96 & 1.4 & 108 & 2.2 & 113 & 3.7 & 95 & 2.2 & 107 & 1.8 & $135 *$ & 4.0 \\
\hline 4-NP & 90 & 0.8 & 97 & 5.0 & 92 & 6.3 & 106 & 1.6 & 100 & 1.1 & 111 & 4.5 & 108 & 6.9 & 107 & 3.2 & 108 & 2.3 & 119 & 2.2 & 109 & 1.2 & 107 & 2.7 & 117 & 2.3 & 109 & 1.5 \\
\hline 1,3,5-TNB & 89 & 1.3 & 95 & 4.9 & 87 & 7.0 & 109 & 2.2 & 109 & 1.4 & 111 & 5.8 & 115 & 7.2 & 111 & 3.7 & 110 & 1.6 & 116 & 0.9 & 115 & 0.3 & 108 & 2.0 & 113 & 1.9 & 116 & 3.1 \\
\hline 2,4-DNP & 85 & 0.6 & 90 & 4.3 & 96 & 2.5 & 110 & 1.5 & 108 & 1.9 & 112 & 5.8 & 119 & 5.3 & 99 & 8.9 & 111 & 2.4 & 120 & 4.1 & 100 & 10.4 & 110 & 2.1 & 118 & 4.5 & 106 & 12.0 \\
\hline 1,2-DNB (surrogate) & 87 & 0.8 & 79 & 7.0 & 97 & 5.3 & 108 & 1.2 & 114 & 2.1 & 97 & 7.6 & 120 & 9.6 & 110 & 3.0 & 106 & 2.2 & 99 & 8.3 & 102 & 7.8 & 105 & 1.7 & 98 & 8.0 & 107 & 10.8 \\
\hline 1,3-DNB & 84 & 0.8 & 77 & 6.7 & 87 & 6.2 & 106 & 2.1 & 110 & 0.4 & 102 & 19.7 & 116 & 6.3 & 104 & 3.6 & 109 & 2.2 & 104 & 0.2 & 101 & 6.8 & 109 & 3.0 & 99 & 5.8 & 103 & 3.5 \\
\hline $2-N P$ & $5+$ & 3.0 & ot & 0.0 & 87 & 0.8 & $7+$ & 3.8 & 103 & 0.6 & $0+$ & 0.0 & 106 & 3.1 & 91 & 40.7 & $6+$ & 3.3 & ot & 0.0 & 82 & 52.9 & $6+$ & 3.5 & ot & 0.0 & 92 & 42.0 \\
\hline NB & 90 & 2.3 & 97 & 7.9 & 79 & 9.7 & 116 & 2.8 & 105 & 0.2 & 116 & 0.1 & 112 & 7.0 & 111 & 6.1 & 116 & 2.4 & 121 & 7.5 & $127 *$ & 0.1 & 110 & 1.4 & 123 & 0.2 & 120 & 3.6 \\
\hline 3,5-DNA (210nm) & $1 \dagger$ & 1.1 & $0+$ & 0.0 & 88 & 9.4 & $0+$ & 0.0 & 102 & 0.8 & $0+$ & 0.0 & 104 & 3.0 & 89 & 68.7 & $0+$ & 0.0 & $0+$ & 0.0 & 75 & 65.1 & $0+$ & 0.0 & $0+$ & 0.0 & $129 *$ & 1.6 \\
\hline 3,5-DNA (254nm) & $1 \dagger$ & 0.8 & $0+$ & 0.0 & 87 & 10.8 & $0+$ & 0.0 & 117 & 0.7 & $0+$ & 0.0 & 119 & 4.0 & 81 & 66.7 & $0+$ & 0.0 & $0+$ & 0.0 & 111 & 2.0 & $0+$ & 0.0 & $0+$ & 0.0 & $74^{*}$ & 63.7 \\
\hline DNAN & 88 & 0.5 & 92 & 6.5 & $72^{\star}$ & 5.4 & 104 & 2 & 89 & 0 & 104 & 1 & 94 & 4 & 92 & 6 & 106 & 2 & 110 & 2 & 93 & 4 & 102 & 2 & 109 & 2 & 91 & 2.6 \\
\hline Tetryl & 89 & 1.8 & 95 & 4.6 & 86 & 16.1 & 110 & 2 & 111 & 1 & 113 & 1 & 117 & 7 & 101 & 4 & 114 & 2 & 117 & 2 & 78 & 9 & 111 & 3 & 111 & 3 & $49+$ & 7.1 \\
\hline$N G$ & 86 & 0.6 & 85 & 5.9 & $39+$ & 10.3 & 115 & 1.6 & 121 & 4.2 & 112 & 6.5 & $129 *$ & 8.4 & 101 & 5.7 & 107 & 3.6 & 117 & 4.5 & 96 & 10.3 & 105 & 1.3 & 115 & 4.8 & 94 & 8.2 \\
\hline 2,4,6-TNT & 87 & 0.9 & 91 & 5.5 & $60 *$ & 12.2 & 113 & 2.2 & 112 & 3.6 & 115 & 4.0 & 120 & 7.4 & 110 & 4.2 & 114 & 2.3 & 122 & 2.0 & 107 & 4.3 & 112 & 2.4 & 120 & 2.1 & 109 & 2.9 \\
\hline 4-Am-2,6-DNT & 90 & 0.2 & 97 & 4.9 & 85 & 8.0 & 110 & 2.1 & 106 & 2.4 & 114 & 4.9 & 11 & 8.5 & 100 & 7.2 & 111 & 1.9 & 108 & 13.1 & 98 & 9.8 & 107 & 3.2 & 102 & 15.6 & 106 & 7.1 \\
\hline 2-Am-4,6-DNT & 92 & 2.4 & 99 & 4.9 & 88 & 6.9 & 112 & 2.3 & 106 & 2.2 & 116 & 4.8 & 117 & 9.0 & 107 & 6.6 & 112 & 4.1 & 114 & 11.7 & 102 & 11.2 & 110 & 2.2 & 117 & 0.1 & 116 & 7.3 \\
\hline 2,6-DNT & $74 *$ & 2.6 & $38+$ & 10.0 & 100 & 11.8 & 99 & 1.0 & 111 & 3.3 & $49+$ & 11.1 & 113 & 1.2 & 80 & 19.9 & 103 & 1.5 & $57 *$ & 1.0 & $68 *$ & 15.4 & 104 & 6.8 & $59 *$ & 0.4 & $70 *$ & 14.4 \\
\hline 2,4-DNT & 84 & 0.8 & $70 *$ & 7.2 & 91 & 13.5 & 94 & 4.8 & 104 & 4.7 & 80 & 3.3 & 106 & 7.5 & 102 & 3.1 & 99 & 4.7 & $73^{*}$ & 40.4 & 93 & 12.2 & 97 & 1.3 & 79 & 28.0 & 103 & 7.5 \\
\hline 2-NT & $1 \dagger$ & 0.5 & $1 \dagger$ & 0.0 & $65^{*}$ & 19.5 & $0+$ & 0.0 & 110 & 2.1 & $0+$ & 0.0 & 110 & 3.8 & $74 *$ & 65.1 & $0+$ & 0.0 & $1 \dagger$ & 1.5 & $73 *$ & 63.2 & $0+$ & 0.0 & $1 \dagger$ & 1.7 & 108 & 1.8 \\
\hline 4-NT & $4 \dagger$ & 1.8 & $1 \dagger$ & 0.3 & 88 & 9.9 & $4 t$ & 2.9 & 109 & 2.6 & $0 t$ & 0.0 & 108 & 4.1 & $67 *$ & 58.7 & $2 t$ & 0.0 & $1 \dagger$ & 0.3 & $52+$ & 47.0 & $2 t$ & 0.0 & $1 \dagger$ & 1.0 & $54 \dagger$ & 47.5 \\
\hline 3-NT & $2+$ & 1.3 & $1 \dagger$ & 0.1 & $75 *$ & 11.7 & $2+$ & 1.3 & 108 & 1.3 & $0+$ & 0.0 & 104 & 6.5 & $65^{*}$ & 56.4 & $2+$ & 1.2 & $0+$ & 0.2 & $59 *$ & 51.7 & $2+$ & 1.2 & $0+$ & 0.2 & $57+$ & 49.4 \\
\hline PETN & 92 & 1.4 & 88 & 14.7 & $73^{*}$ & 12.8 & 110 & 2.5 & 112 & 3.8 & 109 & 15.8 & 117 & 8.2 & 117 & 14.0 & 99 & 5.7 & $132 *$ & 30.2 & 115 & 7.8 & 97 & 3.6 & $134 *$ & \begin{tabular}{|l}
31.4 \\
\end{tabular} & 120 & 11.2 \\
\hline
\end{tabular}


Table 27. Extraction hold-time stability for three laboratory-spiked soil samples over 14 days. (AVG = average; SD = standard deviation)

\begin{tabular}{|c|c|c|c|c|c|c|c|c|c|c|c|c|c|c|c|c|c|c|c|c|c|c|c|c|}
\hline \multirow[b]{5}{*}{ Compound } & \multicolumn{24}{|c|}{ Recoveries (\%) } \\
\hline & \multirow{2}{*}{\multicolumn{6}{|c|}{ Soils Day 0 extraction and analysis }} & \multicolumn{18}{|c|}{ Soils Day 14 extraction and analysis } \\
\hline & & & & & & & \multicolumn{6}{|c|}{ Cold/Dark } & \multicolumn{6}{|c|}{ Room temperature / Dark } & \multicolumn{6}{|c|}{ Room temperature / Light } \\
\hline & \multicolumn{2}{|l|}{ Riley } & \multicolumn{2}{|l|}{ Yuma } & \multicolumn{2}{|c|}{ ASTM FC } & \multicolumn{2}{|l|}{ Riley } & \multicolumn{2}{|l|}{ Yuma } & \multicolumn{2}{|c|}{ ASTM FC } & \multicolumn{2}{|l|}{ Riley } & \multicolumn{2}{|l|}{ Yuma } & \multicolumn{2}{|c|}{ ASTM FC } & \multicolumn{2}{|l|}{ Riley } & \multicolumn{2}{|l|}{ Yuma } & \multicolumn{2}{|c|}{ ASTM FC } \\
\hline & $\begin{array}{l}\text { AVG } \\
(n=3)\end{array}$ & SD & $\begin{array}{l}\text { AVG } \\
(n=3)\end{array}$ & SD & $\begin{array}{l}\text { AVG } \\
(n=3)\end{array}$ & SD & \begin{tabular}{|l|} 
AVG \\
$(n=3)$ \\
\end{tabular} & SD & $\begin{array}{l}\text { AVG } \\
(n=3)\end{array}$ & SD & $\begin{array}{l}\text { AVG } \\
(n=3)\end{array}$ & SD & $\begin{array}{l}\text { AVG } \\
(n=3)\end{array}$ & SD & \begin{tabular}{|l|} 
AVG \\
$(n=3)$ \\
\end{tabular} & SD & $\begin{array}{l}\text { AVG } \\
(n=3)\end{array}$ & SD & $\begin{array}{l}\text { AVG } \\
(n=3)\end{array}$ & SD & $\begin{array}{l}\text { AVG } \\
(n=3)\end{array}$ & SD & $\begin{array}{l}\text { AVG } \\
(n=3)\end{array}$ & SD \\
\hline$N Q$ & $65^{\star}$ & 4.7 & $65^{*}$ & 4.1 & $64^{\star}$ & 4.1 & 98 & 8.3 & $147 \dagger$ & 10.1 & 102 & 6.9 & 90 & 6.9 & 116 & 10.0 & 95 & 3.3 & 98 & 4.9 & 119 & 14.0 & 103 & 8.2 \\
\hline NTO (210nm) & $260+$ & 7.4 & $73^{*}$ & 1.5 & 78 & 4.9 & $33+$ & 3.3 & $35 t$ & 1.4 & $34 \dagger$ & 2.7 & $31 \dagger$ & 2.2 & $35+$ & 2.6 & $35+$ & 1.5 & $31 \dagger$ & 1.8 & $38+$ & 3.8 & $30 t$ & 1.3 \\
\hline o-NBA (surrogate) & 108 & 1.0 & 100 & 1.7 & 97 & 4.1 & 91 & 6.2 & 99 & 1.2 & 95 & 1.8 & 90 & 3.2 & 96 & 2.0 & 93 & 0.8 & 90 & 7.9 & 101 & 1.0 & 97 & 3.4 \\
\hline HMX & $41 \dagger$ & 0.6 & $71^{*}$ & 3.2 & $57 *$ & 14.2 & $43+$ & 1.2 & $64 *$ & 2.3 & $39+$ & 2.1 & $38+$ & 4.6 & $63 *$ & 1.7 & $38+$ & 2.9 & $47 \dagger$ & 1.9 & $68^{*}$ & 2.3 & $41 \dagger$ & 4.1 \\
\hline $\mathrm{RDX}$ & 91 & 1.4 & 113 & 3.4 & 112 & 2.3 & $53+$ & 4.1 & $64 *$ & 7.7 & $44 \dagger$ & 1.3 & $53+$ & 1.0 & $63^{*}$ & 3.9 & $42 \dagger$ & 3.0 & $56+$ & 4.9 & $65 *$ & 5.9 & $44 t$ & 7.9 \\
\hline$P A(210 \mathrm{~nm})$ & $56+$ & 0.5 & 81 & 3.3 & $59 *$ & 0.4 & 83 & 8.0 & 119 & 1.3 & 111 & 0.6 & $67 *$ & 12.2 & 125 & 1.5 & 109 & 2.6 & $69 *$ & 12.3 & $131 *$ & 0.6 & 114 & 0.6 \\
\hline 4-NP & $125^{\star}$ & 1.9 & $125^{*}$ & 1.0 & $127^{\star}$ & 1.4 & 115 & 0.7 & 119 & 0.9 & 120 & 0.9 & 103 & 5.8 & 114 & 0.7 & 117 & 0.8 & 113 & 3.0 & 121 & 0.4 & 122 & 2.1 \\
\hline 1,3,5-TNB & 102 & 2.7 & 115 & 0.7 & 112 & 3.2 & 97 & 0.6 & 109 & 0.7 & 103 & 0.3 & 87 & 3.9 & 107 & 1.4 & 98 & 1.8 & 89 & 4.5 & 114 & 0.6 & 103 & 1.1 \\
\hline 2,4-DNP & 92 & 4.0 & 102 & 5.3 & 103 & 1.0 & 90 & 3.7 & 103 & 1.5 & 101 & 0.5 & 75 & 3.7 & 100 & 3.0 & 96 & 1.6 & 83 & 1.3 & 105 & 1.4 & 102 & 2.4 \\
\hline 1,2-DNB (surrogate) & $125 *$ & 4.3 & 124 & 2.0 & 124 & 5.1 & 121 & 2.7 & 122 & 3.8 & 119 & 0.7 & 110 & 5.8 & 115 & 1.3 & 118 & 2.8 & 117 & 4.0 & 122 & 2.8 & 122 & 2.0 \\
\hline 1,3-DNB & 117 & 1.7 & 118 & 0.6 & 120 & 1.2 & 108 & 0.3 & 111 & 1.0 & 112 & 0.6 & 95 & 4.4 & 106 & 1.0 & 110 & 1.3 & 104 & 2.4 & 112 & 0.3 & 113 & 2.0 \\
\hline $2-N P$ & 98 & 3.9 & 80 & 0.3 & 81 & 1.3 & 90 & 0.4 & 82 & 2.2 & 80 & 0.4 & 81 & 3.3 & 78 & 1.4 & 76 & 0.7 & 89 & 1.5 & 85 & 1.9 & 81 & 1.4 \\
\hline NB & 101 & 1.2 & 113 & 2.3 & 115 & 0.7 & 87 & 1.4 & 110 & 0.2 & 110 & 0.6 & $64 *$ & 4.7 & 105 & 0.9 & 102 & 2.2 & $67 *$ & 1.9 & 112 & 1.2 & 107 & 1.6 \\
\hline 3,5-DNA (210nm) & 114 & 1.7 & 91 & 0.6 & 103 & 9.8 & 99 & 3.1 & 96 & 4.8 & 98 & 4.4 & 92 & 5.1 & 89 & 1.7 & 95 & 2.9 & 103 & 8.0 & 96 & 4.9 & 101 & 2.3 \\
\hline DNAN & 103 & 2.8 & 104 & 1.0 & 109 & 3.3 & 102 & 2.6 & 112 & 1.4 & 107 & 4.1 & 89 & 5.7 & 107 & 1.5 & 102 & 2.5 & 98 & 0.2 & 113 & 3.0 & 105 & 2.6 \\
\hline Tetryl & 114 & 3.9 & 111 & 0.6 & 112 & 0.7 & 100 & 1.3 & 104 & 4.4 & 104 & 3.5 & $68^{*}$ & 7.6 & $66^{*}$ & 3.2 & 75 & 2.7 & $63^{*}$ & 4.7 & $70 *$ & 2.1 & 78 & 2.0 \\
\hline$N G$ & 123 & 4.2 & 118 & 3.5 & 120 & 6.1 & 101 & 0.9 & 105 & 4.7 & 106 & 1.2 & $67 *$ & 5.2 & 102 & 3.7 & 106 & 2.1 & 71* & 3.0 & 106 & 3.9 & 109 & 2.6 \\
\hline 2,4,6-TNT & 118 & 2.0 & 121 & 2.7 & 122 & 3.6 & 104 & 1.6 & 108 & 2.1 & 108 & 0.7 & 82 & 4.0 & 91 & 2.3 & 90 & 3.3 & 84 & 3.7 & 97 & 0.8 & 94 & 2.6 \\
\hline 4-Am-2,6-DNT & 105 & 1.9 & 115 & 1.8 & 117 & 1.4 & 87 & 2.1 & 111 & 1.8 & 112 & 1.8 & $61^{*}$ & 4.0 & 100 & 0.6 & 105 & 2.8 & $64 *$ & 3.2 & 112 & 10.9 & 108 & 1.6 \\
\hline 2-Am-4,6-DNT & 108 & 2.4 & 114 & 3.3 & 115 & 0.8 & 100 & 1.3 & 111 & 1.5 & 111 & 1.1 & 82 & 4.1 & 104 & 1.2 & 106 & 1.9 & 88 & 2.2 & 114 & 5.7 & 111 & 3.4 \\
\hline 2,6-DNT & 116 & 0.6 & 113 & 1.6 & 116 & 1.8 & 115 & 0.2 & 113 & 2.5 & 115 & 0.6 & $74 *$ & 6.4 & 107 & 0.6 & 114 & 2.1 & 115 & 3.1 & 114 & 0.4 & 118 & 1.4 \\
\hline 2,4-DNT & 112 & 0.7 & 115 & 1.0 & 117 & 1.8 & 106 & 1.6 & 112 & 2.1 & 113 & 1.3 & 92 & 2.0 & 107 & 1.1 & 108 & 2.1 & 100 & 3.1 & 113 & 2.0 & 113 & 2.6 \\
\hline 2-NT & 112 & 2.0 & 95 & 3.3 & 102 & 9.1 & 107 & 0.7 & 102 & 2.1 & 108 & 1.5 & 100 & 5.1 & 99 & 0.3 & 106 & 0.6 & 108 & 2.6 & 103 & 2.0 & 109 & 2.7 \\
\hline 4-NT & 113 & 3.1 & 96 & 4.1 & 102 & 9.3 & 109 & 1.3 & 103 & 2.9 & 109 & 1.3 & 96 & 5.5 & 99 & 1.3 & 107 & 1.0 & 105 & 1.5 & 102 & 1.6 & 108 & 2.3 \\
\hline 3-NT & 113 & 0.9 & 96 & 1.5 & 105 & 9.2 & 107 & 0.8 & 101 & 3.9 & 107 & 0.7 & 97 & 5.5 & 98 & 1.2 & 105 & 1.5 & 105 & 2.6 & 103 & 1.1 & 110 & 2.0 \\
\hline PETN & 116 & 4.6 & 111 & 4.6 & 118 & 3.9 & 109 & 1.9 & 109 & 2.4 & 110 & 1.9 & 91 & 5.5 & 102 & 2.5 & 111 & 5.4 & 99 & 2.8 & 110 & 2.4 & 115 & 1.9 \\
\hline
\end{tabular}




\begin{tabular}{|c|c|c|c|c|c|c|c|c|c|c|c|c|c|c|c|c|c|c|c|c|c|c|c|c|}
\hline \multirow[b]{5}{*}{ Compound } & \multicolumn{24}{|c|}{ Recoveries (\%) } \\
\hline & \multirow{2}{*}{\multicolumn{6}{|c|}{ Soils Day 0 extraction and analysis }} & \multicolumn{18}{|c|}{ Soils Day 0 extraction, Day 40 analysis } \\
\hline & & & & & & & \multicolumn{6}{|c|}{ Cold/Dark } & \multicolumn{6}{|c|}{ Room temperature / Dark } & \multicolumn{6}{|c|}{ Room temperature / Light } \\
\hline & \multicolumn{2}{|l|}{ Riley } & \multicolumn{2}{|l|}{ Yuma } & \multicolumn{2}{|c|}{ ASTM FC } & \multicolumn{2}{|l|}{ Riley } & \multicolumn{2}{|l|}{ Yuma } & \multicolumn{2}{|c|}{ ASTM FC } & \multicolumn{2}{|l|}{ Riley } & \multicolumn{2}{|l|}{ Yuma } & \multicolumn{2}{|c|}{ ASTM FC } & \multicolumn{2}{|l|}{ Riley } & \multicolumn{2}{|l|}{ Yuma } & \multicolumn{2}{|c|}{ ASTM FC } \\
\hline & $\begin{array}{l}\text { AVG } \\
(n=3)\end{array}$ & SD & $\begin{array}{l}\text { AVG } \\
(n=3)\end{array}$ & SD & $\begin{array}{l}\text { AVG } \\
(n=3)\end{array}$ & SD & $\begin{array}{l}\text { AVG } \\
(n=3)\end{array}$ & SD & $\begin{array}{l}\text { AVG } \\
(n=3)\end{array}$ & SD & $\begin{array}{l}\text { AVG } \\
(n=3)\end{array}$ & SD & $\begin{array}{l}\text { AVG } \\
(n=3)\end{array}$ & SD & $\begin{array}{l}\text { AVG } \\
(n=3)\end{array}$ & SD & $\begin{array}{l}\text { AVG } \\
(n=3)\end{array}$ & SD & $\begin{array}{l}\text { AVG } \\
(n=3)\end{array}$ & SD & $\begin{array}{l}\text { AVG } \\
(n=3)\end{array}$ & SD & $\begin{array}{l}\text { AVG } \\
(n=3)\end{array}$ & SD \\
\hline$N Q$ & $65^{\star}$ & 4.7 & $65^{*}$ & 4.1 & $64^{*}$ & 4.1 & 85 & 4.1 & 104 & 3.9 & 94 & 0.8 & 84 & 4.0 & 102 & 3.1 & 92 & 2.2 & 83 & 4.0 & 102 & 8.9 & 93 & 2.2 \\
\hline NTO $(210 \mathrm{~nm})$ & $260+$ & 7.4 & $73^{\star}$ & 1.5 & 78 & 4.9 & $148+$ & 4.7 & $149+$ & 1.4 & $143+$ & 3.5 & $149+$ & 5.9 & 153† & 0.9 & $146+$ & 4.1 & $144 \dagger$ & 4.0 & $150+$ & 1.7 & $144 \dagger$ & 3.1 \\
\hline o-NBA (surrogate) & 108 & 1.0 & 100 & 1.7 & 97 & 4.1 & 87 & 8.8 & 97 & 0.9 & 91 & 1.1 & 87 & 8.3 & 99 & 2.9 & 90 & 0.9 & 86 & 8.6 & 97 & 1.3 & 91 & 2.0 \\
\hline HMX & $41 \dagger$ & 0.6 & 71* & 3.2 & $57 \mathrm{v}$ & 14.2 & $35+$ & 2.5 & $60 *$ & 2.5 & $39+$ & 1.0 & $36+$ & 3.8 & $60 *$ & 3.5 & $39 \dagger$ & 0.9 & $35+$ & 3.5 & $61^{*}$ & 2.5 & $39 \dagger$ & 2.0 \\
\hline RDX & 91 & 1.4 & 113 & 3.4 & 112 & 2.3 & $60^{*}$ & 1.7 & $74^{\star}$ & 2.5 & 98 & 4.7 & $60^{*}$ & 1.9 & $72^{\star}$ & 3.2 & $51 \dagger$ & 0.9 & $57^{\star}$ & 6.7 & $71^{\star}$ & 2.8 & $50+$ & 0.4 \\
\hline PA (210 $\mathrm{nm})$ & $56+$ & 0.5 & 81 & 3.3 & $59 *$ & 0.4 & 88 & 2.3 & 104 & 3.4 & 98 & 4.7 & 111 & 4.5 & $152 \dagger$ & 3.1 & $143+$ & 5.9 & 120 & 3.1 & $153 \dagger$ & 3.6 & $142 \dagger$ & 6.2 \\
\hline 4-NP & $125^{\star}$ & 1.9 & $125^{\star}$ & 1.0 & $127^{\star}$ & 1.4 & 107 & 1.2 & 108 & 2.9 & 108 & 4.0 & 107 & 1.5 & 107 & 1.9 & 106 & 4.1 & 106 & 0.8 & 107 & 2.1 & 107 & 3.9 \\
\hline 1,3,5-TNB & 102 & 2.7 & 115 & 0.7 & 112 & 3.2 & 96 & 1.8 & 109 & 1.0 & 102 & 1.9 & 96 & 0.9 & 109 & 1.7 & 103 & 1.8 & 95 & 2.0 & 109 & 0.4 & 103 & 1.7 \\
\hline 2,4-DNP & 92 & 4.0 & 102 & 5.3 & 103 & 1.0 & 87 & 3.3 & 98 & 0.7 & 96 & 2.7 & 86 & 2.7 & 100 & 2.4 & 96 & 2.0 & 88 & 2.0 & 99 & 1.2 & 95 & 2.0 \\
\hline 1,2-DNB (surrogate) & $125 *$ & 4.3 & 124 & 2.0 & 124 & 5.1 & 115 & 1.3 & 117 & 1.7 & 115 & 2.6 & 119 & 0.3 & 117 & 0.7 & 119 & 1.8 & 118 & 0.2 & 119 & 0.9 & 118 & 2.0 \\
\hline 1,3-DNB & 117 & 1.7 & 118 & 0.6 & 120 & 1.2 & 106 & 2.2 & 109 & 1.0 & 110 & 1.9 & 107 & 0.8 & 110 & 1.7 & 110 & 1.9 & 106 & 1.5 & 110 & 0.6 & 110 & 1.3 \\
\hline $2-N P$ & 98 & 3.9 & 80 & 0.3 & 81 & 1.3 & 85 & 1.6 & $71^{\star}$ & 2.1 & $71^{*}$ & 2.0 & 85 & 1.9 & $72^{\star}$ & 1.4 & $71^{\star}$ & 1.4 & 85 & 1.4 & $71^{\star}$ & 0.3 & $71^{\star}$ & 1.7 \\
\hline NB & 101 & 1.2 & 113 & 2.3 & 115 & 0.7 & 89 & 1.6 & 103 & 0.9 & 102 & 2.1 & 92 & 0.3 & 105 & 2.1 & 102 & 2.4 & 91 & 0.7 & 105 & 0.4 & 103 & 1.3 \\
\hline 3,5-DNA (210nm) & 114 & 1.7 & 91 & 0.6 & 103 & 9.8 & 112 & 1.5 & 93 & 1.9 & 110 & 1.0 & 113 & 0.8 & 94 & 1.2 & 111 & 1.1 & 112 & 1.7 & 94 & 0.7 & 110 & 0.7 \\
\hline DNAN & 103 & 2.8 & 104 & 1.0 & 109 & 3.3 & 76 & 0.3 & 82 & 1.0 & 78 & 3.0 & 77 & 0.8 & 82 & 1.3 & 79 & 1.6 & 77 & 0.6 & 82 & 0.9 & 80 & 1.9 \\
\hline Tetryl & 114 & 3.9 & 111 & 0.6 & 112 & 0.7 & 94 & 2.4 & $52 \dagger$ & 2.6 & $55 \dagger$ & 1.4 & $35 t$ & 7.5 & $0 \dagger$ & 0.0 & $0+$ & 0.0 & $4 \dagger$ & 0.3 & $0+$ & 0.0 & $0 \dagger$ & 0.0 \\
\hline$N G$ & 123 & 4.2 & 118 & 3.5 & 120 & 6.1 & 86 & 5.6 & 98 & 2.7 & 97 & 2.5 & 101 & 2.7 & 94 & 7.3 & 99 & 5.4 & 109 & 0.2 & 78 & 3.8 & 84 & 7.8 \\
\hline 2,4,6-TNT & 118 & 2.0 & 121 & 2.7 & 122 & 3.6 & 98 & 2.9 & $135 *$ & 4.7 & $130 *$ & 3.4 & 106 & 0.9 & 112 & 0.3 & 110 & 1.7 & 98 & 0.9 & 109 & 0.3 & 105 & 4.6 \\
\hline 4-Am-2,6-DNT & 105 & 1.9 & 115 & 1.8 & 117 & 1.4 & 94 & 1.4 & 112 & 1.1 & 113 & 1.9 & 87 & 1.3 & 99 & 1.1 & 105 & 10.0 & 97 & 9.1 & 99 & 1.1 & 99 & 0.6 \\
\hline 2-Am-4,6-DNT & 108 & 2.4 & 114 & 3.3 & 115 & 0.8 & 98 & 1.7 & 109 & 1.1 & 107 & 1.5 & 87 & 0.5 & 93 & 1.2 & 97 & 10.4 & 96 & 8.2 & 93 & 0.9 & 92 & 1.0 \\
\hline 2,6-DNT & 116 & 0.6 & 113 & 1.6 & 116 & 1.8 & 96 & 1.7 & 89 & 3.4 & 91 & 7.1 & 100 & 8.1 & 95 & 2.1 & 94 & 4.9 & 95 & 6.2 & 96 & 2.7 & 95 & 1.4 \\
\hline 2,4-DNT & 112 & 0.7 & 115 & 1.0 & 117 & 1.8 & 100 & 4.5 & 111 & 2.5 & 110 & 5.1 & 99 & 4.2 & 107 & 4.0 & 109 & 8.4 & 103 & 2.8 & 106 & 1.2 & 108 & 2.3 \\
\hline 2-NT & 112 & 2.0 & 95 & 3.3 & 102 & 9.1 & 104 & 1.9 & 92 & 1.5 & 104 & 1.5 & 107 & 5.5 & 91 & 1.8 & 103 & 1.5 & 106 & 2.1 & 93 & 2.3 & 103 & 1.1 \\
\hline 4-NT & 113 & 3.1 & 96 & 4.1 & 102 & 9.3 & 104 & 2.3 & 95 & 2.2 & 105 & 2.9 & 106 & 4.6 & 95 & 2.0 & 105 & 1.7 & 106 & 1.3 & 94 & 0.9 & 105 & 0.6 \\
\hline 3-NT & 113 & 0.9 & 96 & 1.5 & 105 & 9.2 & 106 & 3.2 & 92 & 1.0 & 103 & 0.9 & 106 & 2.2 & 92 & 1.1 & 104 & 0.7 & 105 & 2.4 & 92 & 1.4 & 104 & 0.4 \\
\hline PETN & 116 & 4.6 & 111 & 4.6 & 118 & 3.9 & 106 & 1.9 & 110 & 1.0 & 110 & 3.8 & 110 & 2.1 & 110 & 2.6 & 110 & 2.0 & 111 & 2.3 & 111 & 3.5 & 111 & 2.6 \\
\hline
\end{tabular}

Green: $75 \%-125 \%$; light green (*): $64 \%-74 \%$ or $126 \%-135 \%$; red (†): <64\% or $>135 \%$
(DoD QSM Ver5.2 for Solids-lowest LCL: 4-Am-2,6-DNT, $64 \%$, highest UCL: Tetryl, 135\%) 
In contrast to the NQ determinations described above, NTO recoveries were fairly stable from Day o to Day 40, with no storage conditiondependent trends. Only three compounds were detected at reduced levels at Day 40, including HMX, RDX, and Tetryl. HMX recoveries did not seem to depend on storage condition, while RDX recoveries were slightly lower for room temperature samples than those stored at colder temperatures. Tetryl recoveries were much lower for room temperature samples than for cold samples; however, even the cold samples were detected at $50 \%$ of the levels observed on Day o. As in the soil pre-extraction stability study, the majority of compounds in the analysis hold-time stability study were recovered within current DoD QSM limits at both Day o and Day 40, including all other IM compounds tested.

Compound recovery results obtained for Day o of the water stability study also yielded information on compound volatility, as several compounds, specifically 2-NP, 3,5-DNA, 2,6-DNT and 2-/3-/4-NT, were recovered at lower levels on Day o than on Day 7. The compounds were detected at their usual levels within current DoD QSM limits on Day 7 but were nearly absent in samples from Day o. Since samples prepared on Day o were stored for extraction on Day 7 , if the compounds were lost from the original water samples, they would not have been detected in the Day 7 extracts. Because they were, the loss of these more volatile compounds from Day o extracts likely occurred when the extracts obtained by SPE on Day o underwent evaporative concentration under nitrogen. This phenomenon was also observed during SPE method development. Therefore, in general, and especially when any of these compounds are known or suspected to be present in a sample, evaporative concentration of extracts is not recommended.

\subsection{Interlaboratory batch analysis}

A cross-laboratory batch study was carried out at ERDC-EL and ERDCCRREL using five water sources (Table 8) and six soil sources (Table 14). Multiple source samples were used to observe any potential matrix-related variability of extraction and analysis method efficiency. Both high-level (direct-injection) and low-level (SPE) water samples were used. Samples were extracted using the extraction methods and primary HPLC-UV method described in section 2.

Compound recovery results for direct-injection and SPE water extracts are shown in Table 29. For samples that underwent extraction and 
preconcentration by SPE, the majority of compounds were recovered from all five water source samples at similar levels to those observed during SPE method development (Table 10, option B). As expected, NQ recoveries averaged approximately 50\% for SPE extracts at ERDC-EL; however, much higher recoveries were obtained for NQ at ERDC-CRREL, so further investigation is merited. In general, at ERDC-EL, recoveries from reagent water tended to be slightly higher than usual, and at ERDC-CRREL, recovery of Tetryl from all water sources tended to be lower than usual. At both laboratories, it became apparent that using a detection wavelength of $315 \mathrm{~nm}$ rather than $210 \mathrm{~nm}$ for NTO might be preferred, to avoid positive interferences that appear at $210 \mathrm{~nm}$ for field samples. In addition, both laboratories observed low recoveries for NTO, 4-NP, 2-NP, NB (ERDC-EL only), 3,5-DNA and Tetryl (ERDC-CRREL only), and 4-Am-2,6-DNT in tap water samples (pH 9.2) that underwent SPE. Because of the consistency between laboratories, the high $\mathrm{pH}$ of the water samples, and the chemical properties of the compounds affected (acidic or unstable at high $\mathrm{pH}$ ), the low recoveries may have been due to insufficient $\mathrm{pH}$ reduction during the second SPE elution step (using $2 \% \mathrm{HCl} / \mathrm{MeOH}$ ).

In the same manner, during the direct injection cross-laboratory study, much lower recoveries for NTO, and in some cases $o$-NBA surrogate (ERDC-CRREL), were observed for field water samples than for reagent water. As this trend appeared to be $\mathrm{pH}$ related, with NTO recovery being lower for higher-pH water samples (see Table 27), further experiments were carried out in which the $\mathrm{pH}$ of samples to be analyzed by direct injection was adjusted, as discussed in section 3.4.

Compound recovery results for cross-laboratory soil studies are shown in Table 30. The majority of compounds were recovered within current DoD QSM limits, with some compounds having inconsistent recoveries from one soil to another, especially for NQ, NTO, $o$-NBA, and HMX. Some discrepancies were observed between the recoveries obtained by ERDC-EL and ERDC-CRREL, but for the most part, all compounds were recovered within current limits from most soils. 


\begin{tabular}{|c|c|c|c|c|c|c|c|c|c|c|c|c|c|c|c|c|c|c|c|c|c|c|c|c|}
\hline \multirow[b]{4}{*}{ Compound } & \multicolumn{24}{|c|}{ Recoveries (\%) } \\
\hline & \multirow{3}{*}{$\begin{array}{l}\text { Blank } \\
\text { (reagent } \\
\text { water) }\end{array}$} & \multirow{3}{*}{$\begin{array}{l}\text { Blank } \\
\text { spike } \\
\text { (reagent } \\
\text { water) }\end{array}$} & \multirow{3}{*}{\begin{tabular}{|l} 
Matrix \\
spike \\
(HSCN) \\
\end{tabular}} & \multirow{3}{*}{$\begin{array}{l}\text { Matrix } \\
\text { spike } \\
\text { duplicate } \\
\text { (HSCN) }\end{array}$} & \multicolumn{10}{|c|}{ SPE (0.10 mg/L) } & \multicolumn{10}{|c|}{ Direct injection $(2 \mathrm{mg} / \mathrm{L})$} \\
\hline & & & & & \multicolumn{2}{|c|}{ Reagent water } & \multicolumn{2}{|c|}{ Tap water } & \multicolumn{2}{|c|}{$\begin{array}{l}\text { Houston } \\
\text { Shipping } \\
\text { Channel } \\
\text { (North of } \\
\text { Morgan's } \\
\text { Point) water }\end{array}$} & \multicolumn{2}{|c|}{$\begin{array}{l}\text { Yazoo River } \\
\text { water }\end{array}$} & \multicolumn{2}{|c|}{$\begin{array}{l}\text { Rayville, LA } \\
\text { well water }\end{array}$} & \multicolumn{2}{|c|}{ Reagent water } & \multicolumn{2}{|c|}{ Tap water } & \multicolumn{2}{|c|}{$\begin{array}{l}\text { Houston } \\
\text { Shipping } \\
\text { Channel } \\
\text { (North of } \\
\text { Morgan's } \\
\text { Point) water }\end{array}$} & \multicolumn{2}{|c|}{$\begin{array}{l}\text { Yazoo River } \\
\text { water }\end{array}$} & \multicolumn{2}{|c|}{$\begin{array}{l}\text { Rayville, LA } \\
\text { well water }\end{array}$} \\
\hline & & & & & \begin{tabular}{|l} 
AVG \\
$(n=3)$
\end{tabular} & SD & \begin{tabular}{|l} 
AVG \\
$(n=3)$
\end{tabular} & SD & $\begin{array}{l}\text { AVG } \\
(n=3)\end{array}$ & SD & $\begin{array}{l}\text { AVG } \\
(n=3)\end{array}$ & SD & $\begin{array}{l}\text { AVG } \\
(n=3)\end{array}$ & SD & $\begin{array}{l}\text { AVG } \\
(n=3)\end{array}$ & SD & $\begin{array}{l}\text { AVG } \\
(n=3)\end{array}$ & SD & \begin{tabular}{|l} 
AVG \\
$(n=3)$
\end{tabular} & SD & $\begin{array}{l}\text { AVG } \\
(n=3)\end{array}$ & SD & $\begin{array}{l}\text { AVG } \\
(n=3)\end{array}$ & SD \\
\hline NQ & 0 & 23 & 32 & 36 & 50 & 8.6 & 1 & 0.5 & 47 & 3.0 & 50 & 12.4 & 43 & 9.4 & 99 & 3.3 & 92 & 6.6 & 88 & 1.9 & 114 & 8.4 & 84 & 4.6 \\
\hline NTO (210nm) & 0 & 127 & 113 & 136 & 154 & 17.0 & 27 & 14.8 & 158 & 18.1 & 212 & 42.5 & 129 & 17.2 & 115 & 0.9 & 3 & 0.2 & 11 & 0.5 & 15 & 0.7 & 2 & 0.1 \\
\hline NTO $(315 \mathrm{~nm})$ & 0 & 124 & 97 & 120 & 141 & 14.6 & 0 & 0.3 & 110 & 11.3 & 131 & 24.1 & 117 & 15.4 & 116 & 0.7 & 3 & 0.5 & 10 & 0.6 & 14 & 0.8 & 2 & 0.3 \\
\hline o-NBA (surrogate) & 133 & 94 & 93 & 109 & 113 & 10.7 & 111 & 29.1 & 96 & 11.2 & 105 & 10.5 & 112 & 10.7 & 102 & 0.3 & 100 & 0.9 & 105 & 2.1 & 103 & 3.1 & 104 & 2.4 \\
\hline HMX & 0 & 89 & 106 & 107 & 123 & 22.0 & 105 & 19.0 & 103 & 3.7 & 103 & 22.3 & 107 & 6.5 & 98 & 1.2 & 96 & 1.0 & 100 & 0.9 & 100 & 1.2 & 103 & 5.3 \\
\hline $\mathrm{RDX}$ & 0 & 94 & 109 & 110 & 123 & 19.4 & 109 & 12.8 & 106 & 4.9 & 111 & 19.5 & 109 & 8.2 & 102 & 2.6 & 99 & 1.1 & 104 & 0.3 & 103 & 1.1 & 102 & 2.7 \\
\hline PA (210nm) & 0 & 91 & 94 & 120 & 126 & 15.2 & 107 & 28.0 & 109 & 3.7 & 107 & 18.8 & 114 & 8.2 & 88 & 5.8 & 96 & 13.2 & 99 & 12.8 & 96 & 8.4 & 98 & 3.3 \\
\hline$P A(315 \mathrm{~nm})$ & 0 & 86 & 97 & 114 & 114 & 16.1 & 103 & 18.6 & 98 & 8.0 & 96 & 12.2 & 102 & 5.7 & 89 & 1.8 & 91 & 0.9 & 94 & 0.4 & 92 & 1.1 & 92 & 1.3 \\
\hline 4-NP & 0 & 86 & 103 & 105 & 123 & 23.6 & 39 & 5.3 & 103 & 0.4 & 106 & 17.2 & 105 & 4.1 & 94 & 1.2 & 94 & 0.8 & 97 & 1.0 & 95 & 2.0 & 94 & 2.0 \\
\hline 1,3,5-TNB & 0 & 95 & 103 & 110 & 140 & 22.8 & 116 & 23.1 & 109 & 1.2 & 104 & 19.0 & 118 & 8.8 & 100 & 1.4 & 100 & 0.8 & 105 & 2.2 & 103 & 4.2 & 103 & 2.0 \\
\hline 2,4-DNP & 0 & 89 & 104 & 101 & 122 & 20.6 & 104 & 22.8 & 101 & 6.1 & 100 & 15.6 & 108 & 5.7 & 101 & 2.5 & 101 & 1.4 & 105 & 1.8 & 104 & 3.6 & 100 & 2.2 \\
\hline 1,2-DNB (surrogate) & 110 & 89 & 106 & 107 & 124 & 27.6 & 97 & 23.3 & 104 & 5.6 & 108 & 21.1 & 113 & 9.1 & 97 & 1.9 & 96 & 0.5 & 99 & 2.3 & 99 & 1.0 & 99 & 2.5 \\
\hline 1,3-DNB & 0 & 97 & 100 & 114 & 132 & 12.5 & 114 & 25.0 & 109 & 8.0 & 105 & 10.7 & 118 & 13.5 & 100 & 0.8 & 100 & 1.2 & 103 & 0.3 & 102 & 0.5 & 101 & 1.1 \\
\hline $2-N P$ & 0 & 93 & 100 & 105 & 131 & 17.4 & 20 & 3.3 & 109 & 2.1 & 106 & 10.4 & 114 & 2.9 & 104 & 0.2 & 97 & 1.0 & 108 & 0.9 & 107 & 0.6 & 105 & 0.9 \\
\hline NB & 0 & 91 & 101 & 108 & 133 & 24.1 & 52 & 7.2 & 105 & 1.9 & 113 & 21.0 & 114 & 9.5 & 99 & 1.3 & 99 & 0.9 & 102 & 0.9 & 101 & 0.5 & 99 & 0.2 \\
\hline 3,5-DNA (210nm) & 0 & 95 & 103 & 114 & 128 & 9.5 & 90 & 10.9 & 106 & 5.1 & 102 & 3.8 & 117 & 8.6 & 103 & 1.0 & 104 & 2.2 & 108 & 1.3 & 104 & 1.3 & 104 & 0.3 \\
\hline 3,5-DNA (254nm) & 0 & 96 & 102 & 110 & 130 & 9.4 & 108 & 16.6 & 110 & 5.9 & 103 & 2.3 & 117 & 10.1 & 104 & 0.7 & 104 & 1.1 & 107 & 0.9 & 106 & 0.2 & 105 & 0.3 \\
\hline DNAN & 0 & 104 & 102 & 121 & 132 & 1.6 & 109 & 20.0 & 107 & 8.7 & 106 & 4.8 & 128 & 8.0 & 105 & 2.8 & 104 & 2.3 & 109 & 1.4 & 105 & 0.6 & 107 & 3.4 \\
\hline Tetryl & 0 & 95 & 91 & 93 & 132 & 23.3 & 75 & 15.5 & 88 & 3.4 & 85 & 19.6 & 96 & 10.8 & 91 & 1.9 & 85 & 5.9 & 97 & 1.0 & 94 & 1.8 & 98 & 2.1 \\
\hline$N G$ & 0 & 94 & 105 & 104 & 129 & 25.0 & 127 & 34.8 & 100 & 7.5 & 113 & 21.4 & 141 & 7.3 & 94 & 2.7 & 97 & 6.9 & 101 & 5.4 & 96 & 2.4 & 98 & 3.3 \\
\hline 2,4,6-TNT & 0 & 94 & 101 & 108 & 129 & 19.3 & 109 & 29.2 & 99 & 4.9 & 95 & 15.1 & 122 & 12.9 & 100 & 4.8 & 103 & 3.6 & 105 & 2.8 & 102 & 3.5 & 100 & 1.0 \\
\hline 4-Am-2,6-DNT & 0 & 92 & 96 & 97 & 143 & 31.1 & 5 & 1.4 & 95 & 6.1 & 116 & 34.3 & 112 & 12.1 & 97 & 1.3 & 95 & 1.5 & 103 & 1.5 & 100 & 0.2 & 99 & 2.2 \\
\hline 2-Am-4,6-DNT & 0 & 96 & 99 & 106 & 136 & 22.2 & 106 & 19.7 & 100 & 8.3 & 109 & 15.2 & 118 & 15.0 & 97 & 2.0 & 99 & 1.2 & 102 & 3.0 & 99 & 1.6 & 98 & 3.1 \\
\hline 2,6-DNT & 0 & 92 & 96 & 113 & 117 & 6.0 & 91 & 23.9 & 94 & 4.9 & 89 & 8.3 & 103 & 11.2 & 97 & 1.3 & 96 & 2.7 & 104 & 1.9 & 100 & 3.2 & 96 & 1.0 \\
\hline 2,4-DNT & 0 & 103 & 99 & 114 & 121 & 9.5 & 113 & 22.4 & 113 & 6.9 & 100 & 1.3 & 112 & 9.9 & 101 & 1.7 & 102 & 1.6 & 105 & 1.7 & 104 & 0.9 & 103 & 0.8 \\
\hline 2-NT & 0 & 95 & 96 & 106 & 112 & 4.2 & 105 & 15.1 & 104 & 7.1 & 94 & 6.8 & 114 & 11.7 & 102 & 0.4 & 104 & 2.8 & 105 & 1.1 & 104 & 0.8 & 100 & 1.4 \\
\hline 4-NT & 0 & 96 & 93 & 106 & 108 & 13.9 & 95 & 24.6 & 107 & 7.3 & 86 & 10.6 & 109 & 11.4 & 100 & 0.7 & 101 & 1.7 & 104 & 5.0 & 104 & 1.8 & 101 & 4.3 \\
\hline 3-NT & 0 & 92 & 92 & 101 & 110 & 10.9 & 102 & 27.3 & 108 & 8.0 & 94 & 5.9 & 110 & 13.4 & 99 & 1.4 & 99 & 3.0 & 101 & 0.2 & 99 & 0.7 & 100 & 2.7 \\
\hline PETN & 0 & 87 & 101 & 102 & 117 & 20.5 & 94 & 14.6 & 101 & 11.2 & 100 & 26.7 & 97 & 8.6 & 94 & 3.5 & 95 & 4.3 & 101 & 2.6 & 96 & 5.6 & 95 & 3.8 \\
\hline
\end{tabular}




\begin{tabular}{|c|c|c|c|c|c|c|c|c|c|c|c|c|c|c|c|c|c|c|c|c|c|c|c|c|}
\hline \multirow[t]{4}{*}{ ERDC-CRREL } & \multicolumn{24}{|c|}{ Recoveries (\%) } \\
\hline & \multirow{3}{*}{\begin{tabular}{|l} 
Blank \\
(reagent \\
water)
\end{tabular}} & \multirow{3}{*}{$\begin{array}{l}\text { Blank } \\
\text { spike } \\
\text { (reagent } \\
\text { water) }\end{array}$} & \multirow{3}{*}{$\begin{array}{l}\text { Matrix } \\
\text { spike } \\
\text { (Yazoo) }\end{array}$} & \multirow{3}{*}{$\begin{array}{l}\text { Matrix } \\
\text { spike } \\
\text { duplicate } \\
\text { (Yazoo) }\end{array}$} & \multicolumn{10}{|c|}{ SPE (0.10 mg/L) } & \multicolumn{10}{|c|}{ Direct injection $(2 \mathrm{mg} / \mathrm{L})$} \\
\hline & & & & & \multicolumn{2}{|c|}{ Reagent water } & \multicolumn{2}{|c|}{ Tap water } & \multicolumn{2}{|c|}{$\begin{array}{l}\text { Houston } \\
\text { Shipping } \\
\text { Channel } \\
\text { (North of } \\
\text { Morgan's } \\
\text { Point) Water }\end{array}$} & \multicolumn{2}{|c|}{$\begin{array}{l}\text { Yazoo River } \\
\text { water }\end{array}$} & \multicolumn{2}{|c|}{$\begin{array}{l}\text { Rayville, LA } \\
\text { well water }\end{array}$} & \multicolumn{2}{|c|}{ Reagent water } & \multicolumn{2}{|c|}{ Tap water } & \multicolumn{2}{|c|}{$\begin{array}{l}\text { Houston } \\
\text { Shipping } \\
\text { Channel } \\
\text { (North of } \\
\text { Morgan's } \\
\text { Point) water }\end{array}$} & \multicolumn{2}{|c|}{$\begin{array}{l}\text { Yazoo River } \\
\text { water }\end{array}$} & \multicolumn{2}{|c|}{$\begin{array}{l}\text { Rayville, LA } \\
\text { well water }\end{array}$} \\
\hline & & & & & $\begin{array}{l}\text { AVG } \\
(n=3)\end{array}$ & SD & $\begin{array}{l}\text { AVG } \\
(n=3)\end{array}$ & SD & $\begin{array}{l}\text { AVG } \\
(n=3)\end{array}$ & SD & $\begin{array}{l}\text { AVG } \\
(n=3)\end{array}$ & SD & $\begin{array}{l}\text { AVG } \\
(n=3)\end{array}$ & SD & $\begin{array}{l}\text { AVG } \\
(n=3)\end{array}$ & SD & $\begin{array}{l}\text { AVG } \\
(n=3)\end{array}$ & SD & $\begin{array}{l}\text { AVG } \\
(n=3)\end{array}$ & SD & $\begin{array}{l}\text { AVG } \\
(n=3)\end{array}$ & SD & \begin{tabular}{|l} 
AVG \\
$(n=3)$
\end{tabular} & SD \\
\hline NQ & 0 & 92 & $73^{*}$ & 82 & 86 & 7.6 & ot & 0.0 & 82 & 4.7 & $67^{*}$ & 10.4 & $62^{\star}$ & 3.0 & 76 & 15.6 & 88 & 2.2 & 104 & 2.9 & 106 & 1.8 & 103 & 3.0 \\
\hline NTO & 0 & $169 t$ & $161 \dagger$ & $164 t$ & 124 & 2.4 & ot & 0.0 & $140+$ & 17.4 & $144 \dagger$ & 12.6 & $138 t$ & 6.4 & 120 & 26.2 & $2+$ & 0.5 & $8+$ & 1.6 & $11 \dagger$ & 2.0 & $6+$ & 1.4 \\
\hline o-NBA (surrogate) & 117 & $0+$ & $0 \dagger$ & $0+$ & $0+$ & 0.0 & $0 \dagger$ & 0.0 & $0+$ & 0.0 & $0+$ & 0.0 & $0+$ & 0.0 & $286+$ & 159.3 & $30 t$ & 24.7 & $62 *$ & 50.6 & $23+$ & 19.4 & $16 \dagger$ & 13.0 \\
\hline HMX & 0 & $125^{*}$ & 108 & 120 & 115 & 5.4 & 113 & 3.1 & 119 & 4.9 & 110 & 9.6 & 122 & 6.2 & 100 & 3.4 & 98 & 3.7 & 97 & 3.2 & 99 & 3.5 & 96 & 3.2 \\
\hline $\mathrm{RDX}$ & 0 & 118 & 106 & 117 & 83 & 45.9 & 111 & 1.3 & 116 & 8.5 & 103 & 7.6 & 123 & 2.6 & 115 & 4.8 & 117 & 4.9 & 107 & 6.8 & 105 & 6.6 & 106 & 7.9 \\
\hline$P A$ & 0 & 116 & 109 & 118 & 103 & 3.5 & 109 & 0.4 & 119 & 12.4 & 100 & 10.3 & 124 & 4.6 & 98 & 0.9 & 99 & 1.6 & 97 & 0.0 & 98 & 0.5 & 96 & 0.3 \\
\hline 4-NP & 0 & 116 & 96 & 110 & 107 & 5.0 & $33+$ & 1.2 & 112 & 0.9 & 105 & 2.2 & 114 & 2.2 & 101 & 3.1 & 97 & 3.3 & 98 & 2.8 & 99 & 3.1 & 96 & 2.9 \\
\hline 1,3,5-TNB & 0 & 116 & 89 & 108 & 107 & 5.9 & 106 & 4.7 & 101 & 5.4 & $65^{*}$ & 11.0 & 115 & 6.1 & 102 & 4.9 & 99 & 5.1 & 98 & 4.6 & 100 & 4.8 & 97 & 4.6 \\
\hline 2,4-DNP & 0 & $126^{*}$ & 104 & 119 & 122 & 9.6 & $126^{*}$ & 2.8 & 122 & 1.4 & 115 & 2.7 & 125 & 2.5 & 99 & 8.0 & $71^{\star}$ & 4.6 & 91 & 5.2 & $71^{\star}$ & 4.3 & $68^{*}$ & 3.9 \\
\hline 1,2-DNB (surrogate) & 84 & 113 & 100 & 111 & 103 & 6.5 & 99 & 3.2 & 102 & 4.8 & 93 & 9.9 & 108 & 5.4 & $231 \dagger$ & 117.1 & $164 \dagger$ & 115.8 & $162 \dagger$ & 113.4 & $163+$ & 115.0 & $159+$ & 113.0 \\
\hline 1,3-DNB & 0 & 116 & 105 & 110 & 101 & 5.1 & 97 & 4.0 & 109 & 6.6 & 95 & 10.4 & 103 & 5.1 & 101 & 3.3 & 99 & 3.2 & 98 & 2.8 & 99 & 3.2 & 96 & 3.1 \\
\hline $2-N P$ & 0 & 112 & 102 & 108 & 100 & 5.6 & $10+$ & 0.2 & 107 & 5.0 & 96 & 9.6 & 107 & 3.6 & 113 & 13.4 & 99 & 13.0 & 104 & 13.1 & 105 & 13.4 & 103 & 13.3 \\
\hline NB & 0 & 113 & 105 & 107 & 99 & 4.9 & 96 & 4.0 & 106 & 5.3 & 95 & 8.8 & 101 & 3.7 & 101 & 2.8 & 99 & 3.2 & 98 & 2.6 & 99 & 2.7 & 97 & 2.9 \\
\hline 3,5-DNA & 0 & 115 & 104 & 108 & 103 & 6.0 & $44 t$ & 2.0 & 105 & 5.4 & 107 & 9.3 & 106 & 5.9 & 100 & 2.8 & 98 & 3.0 & 98 & 2.6 & 99 & 2.9 & 96 & 2.4 \\
\hline DNAN & 0 & 117 & 106 & 109 & 100 & 4.5 & 98 & 3.9 & 108 & 7.2 & 96 & 10.4 & 102 & 3.0 & 99 & 1.7 & 98 & 1.4 & 97 & 1.2 & 98 & 1.7 & 96 & 1.6 \\
\hline Tetryl & 0 & 118 & $64 *$ & 78 & 108 & 11.1 & $55 t$ & 3.6 & $60^{*}$ & 18.8 & $44 t$ & 3.4 & $42 \dagger$ & 23.1 & $131^{*}$ & 54.4 & 83 & 42.1 & 102 & 39.1 & 101 & 38.2 & 106 & 39.0 \\
\hline$N G$ & 0 & 124 & 95 & 112 & 104 & 6.4 & 113 & 11.6 & 115 & 13.3 & 117 & 10.6 & $128^{*}$ & 14.7 & 98 & 20.4 & 88 & 8.6 & 90 & 5.7 & 98 & 15.2 & 107 & 13.5 \\
\hline 2,4,6-TNT & 0 & 114 & 99 & 111 & 100 & 4.2 & 96 & 3.7 & 103 & 8.4 & 78 & 10.5 & 114 & 4.4 & 103 & 0.9 & 103 & 2.7 & 101 & 2.3 & 103 & 2.3 & 99 & 1.9 \\
\hline 4-Am-2,6-DNT & 0 & 113 & 98 & 104 & 102 & 6.6 & $5+$ & 1.6 & 91 & 4.5 & 95 & 8.9 & 104 & 5.9 & 100 & 2.5 & 98 & 3.1 & 98 & 2.5 & 99 & 2.7 & 96 & 2.8 \\
\hline 2-Am-4,6-DNT & 0 & 115 & 104 & 108 & 102 & 5.7 & $61^{*}$ & 2.2 & 105 & 5.9 & 97 & 9.7 & 105 & 6.2 & 101 & 3.4 & 99 & 3.7 & 98 & 3.3 & 99 & 3.5 & 97 & 3.4 \\
\hline 2,6-DNT & 0 & 114 & 108 & 113 & 93 & 5.3 & 86 & 3.0 & 101 & 7.6 & 86 & 8.9 & 93 & 1.4 & 101 & 2.8 & 99 & 3.5 & 99 & 2.7 & 100 & 3.1 & 96 & 2.4 \\
\hline 2,4-DNT & 0 & 114 & 109 & 114 & 95 & 5.2 & 90 & 3.5 & 105 & 8.9 & 89 & 9.5 & 96 & 4.1 & 101 & 2.8 & 99 & 3.8 & 98 & 1.7 & 100 & 3.4 & 96 & 2.9 \\
\hline 2-NT & 0 & 111 & 103 & 106 & 94 & 4.0 & 92 & 3.5 & 102 & 5.7 & 90 & 8.6 & 97 & 2.0 & 100 & 2.6 & 98 & 2.8 & 97 & 2.4 & 99 & 2.6 & 96 & 2.6 \\
\hline 4-NT & 0 & 113 & 104 & 107 & 96 & 3.6 & 93 & 3.1 & 103 & 7.1 & 91 & 8.6 & 96 & 1.5 & 101 & 3.9 & 99 & 3.6 & 98 & 3.3 & 99 & 3.7 & 97 & 3.6 \\
\hline 3-NT & 0 & 117 & 104 & 107 & 102 & 4.6 & 101 & 3.5 & 113 & 7.9 & 99 & 11.2 & 105 & 2.4 & 99 & 2.0 & 98 & 2.2 & 97 & 1.8 & 98 & 1.8 & 96 & 2.0 \\
\hline PETN & 0 & 115 & 96 & 111 & 108 & 8.2 & 103 & 4.1 & 107 & 4.1 & 100 & 3.5 & 114 & 3.6 & 101 & 3.4 & 99 & 4.2 & 98 & 4.2 & 100 & 4.0 & 95 & 3.0 \\
\hline
\end{tabular}


Table 30. Cross-laboratory batch analysis tests using six different soil sources and the two-stage SE method developed under SERDP ER-2722. (AVG = average; $\mathrm{SD}=$ standard deviation)

\begin{tabular}{|c|c|c|c|c|c|c|c|c|c|c|c|c|c|c|c|c|}
\hline \multirow[t]{4}{*}{ ERDC-EL } & \multicolumn{16}{|l|}{ Recoveries (\%) } \\
\hline & \multirow[b]{3}{*}{$\begin{array}{l}\text { Blank } \\
\text { (hydromatrix) }\end{array}$} & \multirow[b]{3}{*}{$\begin{array}{l}\text { Blank spike } \\
\text { (hydromatrix) }\end{array}$} & \multirow[b]{3}{*}{$\begin{array}{l}\text { Matrix spike } \\
\text { (Aberdeen) }\end{array}$} & \multirow[b]{3}{*}{$\begin{array}{l}\text { Matrix spike } \\
\text { duplicate } \\
\text { (Aberdeen) }\end{array}$} & \multicolumn{12}{|c|}{ Spiked soil (20 mg/kg) } \\
\hline & & & & & \multicolumn{2}{|c|}{ Aberdeen } & \multicolumn{2}{|c|}{ Jefferson } & \multicolumn{2}{|c|}{ Memphis } & \multicolumn{2}{|l|}{ Riley } & \multicolumn{2}{|l|}{ Yuma } & \multicolumn{2}{|c|}{ ASTM Fat Clay } \\
\hline & & & & & $\begin{array}{l}\text { AVG } \\
(n=3)\end{array}$ & SD & $\begin{array}{l}\text { AVG } \\
(n=3)\end{array}$ & SD & $\begin{array}{l}\text { AVG } \\
(n=3)\end{array}$ & SD & $\begin{array}{l}\text { AVG } \\
(n=3)\end{array}$ & SD & $\begin{array}{l}\text { AVG } \\
(n=3)\end{array}$ & SD & $\begin{array}{l}\text { AVG } \\
(n=3)\end{array}$ & SD \\
\hline$N Q$ & 0 & 99 & 100 & 94 & 90 & 1.6 & 85 & 0.7 & 93 & 1.7 & 79 & 4.0 & 98 & 1.4 & 82 & 1.8 \\
\hline NTO (210nm) & 0 & 124 & 76 & $74^{\star}$ & 76 & 0.8 & $72^{\star}$ & 1.8 & 105 & 2.2 & $129^{\star}$ & 3.1 & 104 & 0.9 & 97 & 0.5 \\
\hline NTO $(315 \mathrm{~nm})$ & 0 & 120 & $69^{*}$ & $68^{\star}$ & $64^{*}$ & 0.9 & $66^{*}$ & 1.7 & 98 & 1.5 & 84 & 2.0 & 100 & 1.2 & 90 & 0.7 \\
\hline o-NBA (surrogate) & 116 & 108 & 100 & 97 & 95 & 1.0 & $75^{*}$ & 2.2 & 102 & 0.7 & 86 & 1.2 & 105 & 1.7 & 93 & 1.1 \\
\hline $\mathrm{HMX}$ & 0 & 106 & 90 & 89 & 83 & 2.6 & $70 *$ & 1.0 & 91 & 1.0 & $55+$ & 2.7 & 86 & 2.6 & $56+$ & 1.0 \\
\hline RDX & 0 & 106 & 96 & 94 & 89 & 3.8 & 76 & 1.2 & 93 & 1.5 & $66^{*}$ & 2.2 & 96 & 1.5 & $65^{*}$ & 2.0 \\
\hline$P A(210 n m)$ & 0 & 101 & 92 & 86 & 84 & 1.5 & 87 & 7.5 & 90 & 4.4 & 82 & 4.7 & 99 & 6.2 & 82 & 2.4 \\
\hline$P A(315 \mathrm{~nm})$ & 0 & 98 & 94 & 92 & 88 & 2.3 & 85 & 1.2 & 94 & 2.0 & 79 & 2.9 & 98 & 1.4 & 89 & 0.9 \\
\hline 4-NP & 0 & 100 & 97 & 95 & 91 & 1.4 & 90 & 2.7 & 94 & 1.5 & 86 & 1.0 & 99 & 2.0 & 92 & 2.0 \\
\hline 1,3,5-TNB & 0 & 107 & 98 & 96 & 93 & 1.1 & 84 & 1.0 & 100 & 1.1 & 82 & 0.4 & 106 & 1.5 & 92 & 1.5 \\
\hline $2,4-D N P$ & 0 & 104 & 100 & 98 & 95 & 1.6 & 82 & 1.8 & 99 & 1.1 & 80 & 2.0 & 103 & 6.7 & 91 & 2.7 \\
\hline 1,2-DNB (surrogate) & 121 & 103 & 99 & 98 & 98 & 0.6 & 96 & 0.5 & 100 & 2.3 & 95 & 1.8 & 103 & 2.2 & 97 & 0.5 \\
\hline 1,3-DNB & 0 & 105 & 103 & 100 & 99 & 0.3 & 98 & 0.7 & 102 & 0.8 & 94 & 0.9 & 107 & 1.4 & 99 & 0.7 \\
\hline $2-N P$ & 0 & 109 & 103 & 101 & 94 & 0.4 & 90 & 0.1 & 84 & 1.0 & 91 & 1.7 & 93 & 1.6 & 85 & 0.9 \\
\hline NB & 0 & 107 & 102 & 100 & 97 & 0.7 & 86 & 0.3 & 100 & 1.5 & 77 & 0.8 & 105 & 1.2 & 96 & 0.5 \\
\hline 3,5-DNA (210nm) & 0 & 113 & 102 & 101 & 93 & 2.7 & 92 & 1.3 & 77 & 3.8 & 93 & 3.2 & 90 & 0.5 & 92 & 0.9 \\
\hline 3,5-DNA (254nm) & 0 & 111 & 101 & 99 & 93 & 0.3 & 91 & 0.9 & 76 & 1.6 & 93 & 1.5 & 88 & 0.7 & 91 & 1.0 \\
\hline$D N A N$ & 0 & 113 & 108 & 104 & 101 & 1.8 & 100 & 3.0 & 105 & 4.0 & 94 & 1.5 & 112 & 1.6 & 101 & 0.1 \\
\hline Tetryl & 0 & 95 & 96 & 91 & 90 & 2.8 & 97 & 0.8 & 89 & 1.7 & 84 & 1.0 & 99 & 1.1 & 89 & 3.4 \\
\hline NG & 0 & 110 & 94 & 90 & 96 & 4.7 & 94 & 2.1 & 97 & 2.5 & 90 & 1.6 & 107 & 2.6 & 99 & 4.7 \\
\hline 2,4,6-TNT & 0 & 113 & 94 & 94 & 95 & 4.0 & 94 & 0.4 & 99 & 2.3 & 86 & 3.2 & 107 & 2.1 & 94 & 2.8 \\
\hline 4-Am-2,6-DNT & 0 & 98 & 101 & 98 & 96 & 1.5 & 87 & 1.7 & 99 & 1.0 & $73 *$ & 0.8 & 103 & 1.3 & 95 & 1.2 \\
\hline 2-Am-4,6-DNT & 0 & 101 & 102 & 99 & 98 & 2.3 & 94 & 2.0 & 101 & 2.4 & 86 & 1.5 & 103 & 2.6 & 97 & 0.6 \\
\hline 2,6-DNT & 0 & 104 & 107 & 102 & 102 & 4.5 & 102 & 5.1 & 107 & 4.4 & 99 & 3.7 & 109 & 4.0 & 102 & 4.4 \\
\hline 2,4-DNT & 0 & 105 & 102 & 95 & 96 & 0.8 & 96 & 0.9 & 100 & 1.2 & 89 & 0.6 & 106 & 2.8 & 96 & 0.2 \\
\hline 2-NT & 0 & 107 & 101 & 100 & 94 & 1.2 & 92 & 0.3 & 80 & 1.7 & 93 & 1.2 & 89 & 0.8 & 92 & 1.4 \\
\hline 4-NT & 0 & 108 & 102 & 94 & 94 & 1.8 & 91 & 2.7 & 82 & 2.3 & 91 & 3.9 & 89 & 1.4 & 88 & 1.1 \\
\hline 3-NT & 0 & 104 & 99 & 95 & 92 & 1.2 & 91 & 1.6 & 76 & 1.7 & 90 & 2.8 & 86 & 1.8 & 88 & 1.0 \\
\hline
\end{tabular}




\begin{tabular}{|c|c|c|c|c|c|c|c|c|c|c|c|c|c|c|c|c|}
\hline PETN & 0 & 99 & 105 & 92 & 94 & 3.1 & 94 & 3.1 & 96 & 4.4 & 88 & 2.7 & 99 & 7.4 & 98 & 0.9 \\
\hline ERDC-CRREL & \multicolumn{16}{|l|}{ Recoveries (\%) } \\
\hline & \multirow[b]{3}{*}{$\begin{array}{l}\text { Blank } \\
\text { (hydromatrix) }\end{array}$} & \multirow[b]{3}{*}{$\begin{array}{l}\text { Blank spike } \\
\text { (hydromatrix) }\end{array}$} & \multirow[b]{3}{*}{$\begin{array}{l}\text { Matrix spike } \\
\text { (Yuma) }\end{array}$} & \multirow[b]{3}{*}{$\begin{array}{l}\text { Matrix spike } \\
\text { duplicate } \\
\text { (Yuma) }\end{array}$} & \multicolumn{12}{|c|}{ Spiked soil (20 mg/kg) } \\
\hline & & & & & \multicolumn{2}{|c|}{ Aberdeen } & \multicolumn{2}{|c|}{ Jefferson } & \multicolumn{2}{|c|}{ Memphis } & \multicolumn{2}{|l|}{ Riley } & \multicolumn{2}{|l|}{ Yuma } & \multicolumn{2}{|c|}{ ASTM Fat Clay } \\
\hline Compound & & & & & $\begin{array}{l}\text { AVG } \\
(n=3)\end{array}$ & SD & $\begin{array}{l}\text { AVG } \\
(n=3)\end{array}$ & SD & $\begin{array}{l}\text { AVG } \\
(n=3)\end{array}$ & SD & $\begin{array}{l}\text { AVG } \\
(n=3)\end{array}$ & SD & $\begin{array}{l}\text { AVG } \\
(n=3)\end{array}$ & SD & $\begin{array}{l}\text { AVG } \\
(n=3)\end{array}$ & SD \\
\hline$N Q$ & 0 & $186+$ & 120 & 117 & $148+$ & 3.5 & 89 & 3.7 & $133^{\star}$ & 23.6 & $147 \dagger$ & 7.3 & 108 & 3.9 & 87 & 2.3 \\
\hline NTO & 0 & $58^{\star}$ & $38+$ & 81 & $29+$ & 3.1 & $74^{*}$ & 9.5 & $37 t$ & 7.7 & $40+$ & 6.9 & 76 & 10.7 & $53+$ & 5.4 \\
\hline o-NBA (surrogate) & 119 & 123 & 90 & 97 & $44 \dagger$ & 2.6 & 92 & 5.3 & 90 & 41.4 & $44 t$ & 3.1 & 98 & 2.6 & 95 & 2.6 \\
\hline HMX & 0 & $126^{*}$ & 90 & 90 & 96 & 1.0 & 85 & 1.7 & 101 & 4.5 & $73 *$ & 0.5 & 91 & 0.2 & $71^{*}$ & 2.1 \\
\hline RDX & 0 & $140 \dagger$ & 115 & 118 & 114 & 3.5 & 103 & 2.7 & 120 & 7.5 & 99 & 2.0 & 112 & 0.9 & 97 & 2.5 \\
\hline$P A$ & 0 & $141 \dagger$ & 123 & $127^{\star}$ & 117 & 5.3 & 110 & 2.3 & 122 & 9.0 & 100 & 1.7 & 115 & 1.4 & 107 & 3.3 \\
\hline 4-NP & 0 & $131 *$ & 122 & $131^{\star}$ & 119 & 5.7 & 111 & 2.6 & 120 & 10.3 & 113 & 1.7 & 117 & 1.4 & 110 & 3.9 \\
\hline 1,3,5-TNB & 0 & $125 *$ & 120 & $129 *$ & 116 & 5.3 & 100 & 2.4 & 119 & 10.5 & 102 & 1.8 & 117 & 1.4 & 105 & 3.9 \\
\hline $2,4-D N P$ & 0 & 114 & 97 & 105 & 109 & 4.0 & 94 & 3.7 & 103 & 6.2 & 88 & 0.7 & 103 & 1.4 & 92 & 2.2 \\
\hline 1,2-DNB (surrogate) & 101 & $128 *$ & 121 & $129 *$ & 121 & 6.3 & 112 & 1.8 & 118 & 10.8 & 112 & 1.6 & 116 & 2.0 & 110 & 3.4 \\
\hline 1,3-DNB & 0 & 125 & 119 & $128^{*}$ & 118 & 5.5 & 110 & 1.3 & 113 & 11.8 & 111 & 0.9 & 115 & 2.9 & 109 & 4.2 \\
\hline $2-N P$ & 0 & 117 & 98 & 100 & 108 & 3.2 & 98 & 0.2 & 87 & 7.6 & 103 & 0.2 & 95 & 3.3 & 88 & 1.1 \\
\hline NB & 0 & $133^{*}$ & 105 & 112 & 109 & 3.9 & 100 & 0.5 & 84 & 8.6 & 108 & 0.4 & 97 & 3.2 & 96 & 2.8 \\
\hline 3,5-DNA & 0 & $127 *$ & 119 & $130 *$ & 117 & 5.6 & 101 & 2.6 & 118 & 10.8 & 95 & 1.8 & 116 & 1.4 & 108 & 3.9 \\
\hline DNAN & 0 & 121 & 120 & $130^{*}$ & 119 & 5.8 & 110 & 2.2 & 119 & 11.1 & 110 & 1.7 & 117 & 1.1 & 109 & 4.0 \\
\hline Tetryl & 0 & $35 \dagger$ & $58^{*}$ & $133 v$ & 103 & 20.0 & 119 & 16.3 & $73 *$ & 33.3 & 121 & 4.7 & 99 & 14.4 & 75 & 4.7 \\
\hline NG & 0 & $152 \dagger$ & 111 & 121 & 114 & 9.1 & 99 & 0.4 & 116 & 22.3 & 101 & 8.0 & 103 & 4.0 & 123 & 17.0 \\
\hline 2,4,6-TNT & 0 & $137 \dagger$ & 123 & 123 & 113 & 6.8 & 106 & 1.3 & 106 & 13.6 & 100 & 1.3 & 111 & 4.2 & 105 & 4.0 \\
\hline 4-Am-2,6-DNT & 0 & 127 (* $^{*}$ & 120 & 131 (* & 118 & 5.9 & 103 & 2.2 & 120 & 10.6 & 92 & 2.4 & 116 & 1.3 & 111 & 4.0 \\
\hline 2-Am-4,6-DNT & 0 & 124 & 120 & 130 (* & 120 & 5.8 & 110 & 2.5 & 121 & 10.9 & 105 & 2.0 & 117 & 1.2 & 111 & 3.9 \\
\hline 2,6-DNT & 0 & $0 \dagger$ & 121 & 131(* & 117 & 6.3 & 109 & 1.6 & 112 & 12.7 & 112 & 1.0 & 115 & 3.9 & 109 & 5.4 \\
\hline 2,4-DNT & 0 & 111 & 120 & 131 (* & 117 & 6.6 & 109 & 2.2 & 112 & 13.3 & 110 & 1.4 & 114 & 3.9 & 109 & 4.7 \\
\hline $2-N T$ & 0 & $133{ }^{*}$ & 108 & 115 & 110 & 3.9 & 102 & 0.1 & 88 & 10.6 & 109 & 0.2 & 99 & 4.2 & 97 & 3.8 \\
\hline 4-NT & 0 & 129 (* & 107 & 113 & 114 & 4.1 & 102 & 0.8 & 84 & 12.2 & 107 & 0.6 & 98 & 4.9 & 93 & 4.3 \\
\hline 3-NT & 0 & 1351* & 106 & 112 & 109 & 4.0 & 100 & 1.0 & 81 & 11.3 & 105 & 0.8 & 95 & 5.1 & 92 & 3.3 \\
\hline PETN & 0 & 123 & 124 & $132{ }^{*}$ & 120 & 6.9 & 112 & 2.3 & 122 & 12.1 & 115 & 2.9 & 117 & 2.0 & 112 & 4.8 \\
\hline
\end{tabular}

Green: $75 \%-125 \%$; light green $\left({ }^{*}\right)$ : $64 \%-74 \%$ or $126 \%-135 \%$; red $(\dagger):<64 \%$ or $>135 \%$

(DoD QSM Ver5.2 for Solids-lowest LCL: 4-Am-2,6-DNT, 64\%; highest UCL: Tetryl, 135\%) 


\section{Conclusions and Implications for Future Research and Implementation}

The primary objective of this project was to fulfill the requirements of SERDP SON ERSON-17-02 by developing new methods of extraction, preconcentration, and analytical separation and quantitation of 17 legacy as well as 7 IM compounds, daughter products of IM, and other munition compounds absent from USEPA Method $8330 \mathrm{~B}$. The goal was to produce a single, standardized method for simultaneous analysis of legacy and IM compounds in environmental matrices. HPLC-UV and HPLC-MS methods were developed as well as extraction methods for waters (direct-injection and SPE), soils (two-stage SE), and tissues (one-stage SE). An interference reduction procedure was also developed for tissues. The development of these methods should produce cost savings with a minimal increase in environmental monitoring efforts and no modification of existing sample collection procedures.

During this project, two separate HPLC-UV column separation methods were developed, enabling orthogonal confirmation of analyte concentration down to low $\mu \mathrm{g} / \mathrm{L}$ levels in water, soil or sediment, and tissue samples. Preconcentration of water samples using SPE can lower analyte detection levels to sub $\mu \mathrm{g} / \mathrm{L}$ levels with sufficient concentration factors applied. A less sensitive HPLC-MS scan mode method was developed, which can be used as an alternative to a secondary column confirmation method. Sample preparation and solvent gradients were refined for optimal method performance. Furthermore, the SPE and SE methods (and interference reduction method for tissues) developed for this project yield compound recoveries for all analytes of interest and surrogates within currently accepted limits, with the recoveries for many of the compounds consistently better than current methods.

The development of these extraction and analysis methods to simultaneously analyze environmentally copresent legacy and IM compounds was necessary to enable future monitoring of co-occurring components at firing ranges, demilitarization facilities, manufacturing facilities, and environmental sites, where munitions are tested, produced, and detected (Felt et al. 2013; Walsh et al. 2014). The primary and secondary HPLC-UV methods reduce total analysis time by approximately 
$25 \%$ versus using four different analytical methods as has previously been required (two methods for legacy and two different methods for IM). In addition, the labor and supply cost savings because of coextraction and sample preparation is at least $50 \%$, as only a single extraction procedure and analytical sample preparation are required versus up to four (including confirmation analyses), because the sample preparation for the primary and secondary methods are the same. Furthermore, the products of this work will contribute to the ability to conduct fate and transport studies for IM compounds by providing a standardized method for quantitation of IM and legacy materials needed to determine long-term effects.

The method development work executed under SERDP ER-2722 will continue under ESTCP ER19-D1-5078 (started February 2019) to validate the methods. The validation will consist of round-robin comparison studies, carried out with the cooperation of USEPA, with the end goal of producing an addendum to the current USEPA Method 8330B. Eight participants, including DoD laboratories (ERDC-EL and -CRREL), another federal laboratory (USGS National Water Quality Laboratory, NELAP certified), a munition manufacturing laboratory (American Ordnance), and several ELAP- or NELAP-certified, or both, commercial laboratories are participating in the validation studies. The standardization and publication of the validated methods will enable commercial and DoD laboratories to perform the standardized methodology on a broad commercial scale. 


\section{References}

Avci, G. F. Y., B. Anilanmert, and S. Cengiz. 2017. Rapid and Simple Analysis of Trace Levels of Three Explosives in Soil by Liquid Chromatography-Tandem Mass Spectrometry. Acta Chromatographica, 29(1), 45-56.

Barrie, A. 2013. New Generation of Explosives for the Army. http:// www.military.com/dailynews/2013/04/01/new-generation-of-explosives- for-the-army.html. (Accessed 27 Jun 2019).

Bauer, C. F., T. F. Jenkins, S. M. Koza, P. W. Schumacher, P. H. Miyares, M. E. Walsh. 1989. Development of an Analytical Method for the Determination of Explosive Residues in Soil, Part 3, Collaborative Test Results and Final Performance Evaluation. USACE Cold Regions Research and Engineering Laboratory [Hanover, NH], CRREL Report 89-9.

Bednar, A. J. Analytical Method Development for Simultaneous Determination of Legacy and IM Constituents. Presented at the SERDP/ESTCP Symposium, Washington, D.C., Nov 28, 2018.

Boopathy, R. 2000. Formation of Aniline as a Transient Metabolite during the Metabolism of Tetryl by a Sulfate-Reducing Bacterial Consortium. Curr. Microbiol., 40, 190-193.

Brannon, J. M., T. F. Jenkins, L. V. Parker, P. Deliman, J. A. Gerald, C. Ruiz, B. Porter, and W. M. Davis. 2000. Procedures for Determining Integrity of UXO and Explosives Soil Contamination at Firing Ranges. ERDC TR-oo-4, Vicksburg, MS.

Chendorain, M. D., L. D. Stewart, and B. Packer. 2005. Corrosion of Unexploded Ordnance in Soil-Field Results. Environmental Science and Technology, 39, 2442-2447.

Crouch, R. A., J. C. Smith, B. S. Stromer, C. T. Hubley, S. Beal, G. R. Lotufo, A. D. Butler, et al. 2020. "Methods for Simultaneous Determination of Legacy and Insensitive Munition (IM) Constituents in Aqueous, Soil/Sediment, and Tissue Matrices. Talanta 217: 121008. https://doi.org/10.1016/j.talanta.2020.121008.

Crouch, R. A., C. T. Hubley, J. C. Smith, S. Beal, A. L. Russell, G. R. Lotufo, J. G. Coleman, J. L. Clausen, B. C. Giordano, M. T. Montgomery, and A. J. Bednar. 2018. Development and Optimization of New Methods for Simultaneous Extraction and Quantitation of Legacy and Insensitive Munition Compounds. Presented at the 2018 Department of Defense Environmental Monitoring and Data Quality Workshop, Orlando, FL, Apr 10-12, 2018.

Crouch, R. A., J. C. Smith, C. T. Hubley, S. Beal, G. R. Lotufo, A. D. Butler, D. A. Rosado, A. L. Russell, J. G. Coleman, J. L. Clausen, B. C. Giordano, M. T. Montgomery, and A. J. Bednar. 2018. Development and Optimization of Preparatory and Analytical Methods for Simultaneous Determination of Insensitive and Legacy Munition Compounds in Complex Environmental Matrices. Presented at the SERDP/ESTCP Symposium, Washington, D.C., Nov 27, 2018. 
De Vries, J. E., and E. St. Clair-Gantz. 1954. Spectrophotometric Studies of Dissociation Constants of Nitroguanidines, Triazoles and Tetrazoles. JACS, 76(4), 1008-1010.

Dontsova, K., S. Taylor, R. Pesce-Rodriguez, M. Brusseau, J. Arthur, N. Mark, M. Walsh, J. Lever, and J. Šimůnek. 2014. "Dissolution of NTO, DNAN, and Insensitive Munitions Formulations and Their Fates in Soils.” ERDC/CRREL TR-14-23. Hanover, NH: USACE Cold Regions Research and Engineering Laboratory.

Douglas, T. A., L. Johnson, M. Walsh, and C. Collins. 2009. A Time Series Investigation of the Stability of Nitramine and Nitroaromatic Explosives in Surface Water Samples at Ambient Temperature. Chemosphere, 76, 1-8.

Felt, D., L. Gurtowski, C. C. Nestler, J. Johnson, and S. Larson. 2016. A Two-Stage Extraction Procedure for Insensitive Munition (IM) Explosive Compounds in Soils. Chemosphere, 165, 18-26.

Felt, D., J. L. Johnson, S. Larson, B. Hubbard, K. Henry, C. Nestler, and J. H. Ballard. 2013. "Evaluation of Treatment Technologies for Wastewater from Insensitive Munitions Production: Phase 1: Technology Down-Selection.” ERDC/EL TR-1320. Vicksburg, MS: US Army Corps of Engineers, Engineer Research and Development Center.

Fung, V., B. Schreiber, C. Patel, P. Samuels, P. Vinh, and X.-L. Zhao. 2012. Process Improvement and Optimization of Insensitive Explosive IMX-101. Presented at the 2012 Insensitive Munitions \& Energetic Material Technology Symposium, Las Vegas, NV, May 16, 2012.

Gapeev, A., M. Sigman, and J. Yinon. 2003. Liquid Chromatography/Mass Spectrometry Analysis of Explosives: RDX Adduct Ions. Rapid Comm. Mass Spec., 17, 943-948.

Goerlitz, D. F. 1979. Analysis of Picric Acid in Water by High-Performance Liquid Chromatography. US Geological Survey Open-File Report, 79-207, 12 pp.

Harvey, S. D., R. J. Fellows, J. A. Campbell, and D. A. Cataldo. 1992. Determination of the Explosive 2,4,6-Trinitrophenylmethylnitramine (Tetryl) and its Transformation Products in Soil. J. of Chromatography, 605, 227-240.

Hawari, J., F. Manteil-Rivera, N. Perreault, A. Halasz, L. Paquet, Z. Radovic-Hrapovic, S. Dechamps, S. Thiboutot, and G. Ampleman. 2015. Environmental Fate of 2,4Dinitroanisole (DNAN) and its Related Products. Chemosphere, 119, 16-23.

Hubley, C. T. 2017. Extraction and Analysis of IMX Formulations in the Presence of Legacy and other Munitions. Presented at the SERDP/ESTCP Symposium, Washington, D.C.

Hubley, C. T., J. C. Smith, S. Beal, A. L. Russell, G. R. Lotufo, J. G. Coleman, J. L. Clausen, B. C. Giordano, M. T. Montgomery, and A. J. Bednar. 2017. Development and Optimization of New Methods for Simultaneous Extraction and Quantitation of Legacy and Insensitive Munition Compounds. Presented at the 2017 Department of Defense Environmental Monitoring and Data Quality Workshop, Phoenix, AZ. 
Jenkins, T. F., J. C. Pennington, T. A. Ranney, T. E. Berry, Jr., P. H. Miyares, M. E. Walsh, A. D. Hewitt, N. Perron, L. V. Parker, C. A. Hayes, and Maj E. Wahlgren. 2001. "Characterization of Explosives Contamination at Military Firing Ranges." ERDC/CRREL TR-01-05. Hanover, NH: U. S. Army Engineer Research and Development Center.

Jenkins, T. F. 1994. "Evaluation of Pre-Extraction Analytical Holding Times for Tetryl in Soil.” ERDC/CRREL SR-94-5. Hanover, NH: USACE Cold Regions Research and Engineering Laboratory.

Jenkins, T. F., A. D. Hewitt, C. L. Grant, S. Thiboutot, G. Ampleman, M. E. Walsh, T. A. Ranney, C. A. Ramsey, A. J. Palazzo, and J. C. Pennington. 2006. Identity and Distribution of Residues of Energetic Compounds at Army Live-Fire Training Ranges. Chemosphere 63, 1280-1290.

Jenkins, T. F., S. Thiboutot, G. Ampleman, A. D. Hewitt, M. E. Walsh, T. A. Ranney, C. A. Ramsey, C. L. Grant, C. M. Collins, S. Brochu, S. R. Bigl, and J. C. Pennington. 2005. "Identity and Distribution of Residues of Energetic Compounds at Military Live-Fire Training Ranges.” ERDC/CRREL TR-05-10. Hanover, NH: U.S. Army Research and Engineering Laboratory.

Jenkins, T. F., and M. E. Walsh. 1994. Instability of Tetryl to Soxhlet Extraction. $J$. Chrom. A, 662, 178-184.

Jiang, G. 2010. Simultaneous UHPLC/MS Analyses of Explosive Compounds. Thermo Fisher Scientific Application Note, 51879.

Kaplan, D. L., J. H. Cornell, and A. M. Kaplan. 1982. Decomposition of Nitroguanidine. Environ. Sci. Technol., 16(8), 488-492.

Kiebler, R., and P. Manz. 2010. Picatinny Insensitive Munitions (IM) Efforts Paying Dividends. Army AL\&T: Joint Systems and Equipment, Apr-Jun 2010, pp 48-50.

Kinghorn, R., C. Milner, and J. Zweigenbaum. 2005. Analysis of Trace Residues of Explosive Materials by Time-of-Flight LC/MS. Agilent Technologies Application Note, 5989-2449EN.

Larson, S. L., R. P. Jones, L. Escalon, and D. Parker. 1999. Classification of Explosives Transformation Products in Plant Tissue. Environ. Tox. \& Chem., 18(6), 12701276.

Lide, D.R. (Ed.). (2005) CRC Handbook of Chemistry and Physics. CRC Press, Boca Raton, FL.

Mainiero, C. 2015. Picatinny Employees Recognized for Insensitive Munitions. https://www.army.mil/article/148873/picatinny_employees_recognized_for_insensitive_muniti ons. (Accessed 27 Jun 2019).

Newman, K. E. 2010. Army Insensitive Munitions Board (AIMB) Aids in Weapon Systems' Development and Acquisition. Army AL\&T: Joint Systems and Equipment, Apr-Jun 2010, pp 44-47. 
Pennington, J. C., T. F. Jenkins, G. Ampleman, S. Thiboutot, J. M. Brannon, J. Lynch, T. A. Ranney, et al. 2002. "Distribution and Fate of Energetics on DoD Test and Training Ranges: Report 2.” ERDC TR-02-8. Vicksburg, MS: U.S. Army Engineer Research and Development Center.

Pennington, J. C., T. F. Jenkins, G. Ampleman, S. Thiboutot, J. M. Brannon, J. Lewis, J. E. Delaney, et al. 2003. "Distribution and Fate of Energetics on DoD Test and Training Ranges: Report 3.” ERDC TR-03-2. Vicksburg, MS: U.S. Army Engineer Research and Development Center.

Pennington, J. C., T. F. Jenkins, G. Ampleman, S. Thiboutot, J. M. Brannon, J. Clausen, A. D. Hewitt, et al. 2004. "Distribution and Fate of Energetics on DoD Test and Training Ranges: Interim Report 4.” ERDC TR-04-4. Vicksburg, MS: U.S. Army Engineer Research and Development Center.

Pennington, J. C., T. F. Jenkins, J. M. Brannon, J. Lynch, T. A. Ranney, T. E. Berry, Jr., C. A. Hayes, et al. 2001. "Distribution and Fate of Energetics on DoD Test and Training Ranges: Interim Report 1.” ERDC TR-01-13. Vicksburg, MS: U.S. Army Engineer Research and Development Center.

Pennington, J. C., T. F. Jenkins, S. Thiboutot, G. Ampleman, J. Clausen, A. D. Hewitt, J. Lewis, et al. 2005. "Distribution and fate of energetics on DoD test and training ranges. Report 5.” ERDC TR-05-2. Vicksburg, MS: U.S. Army Engineer Research and Development Center.

Pennington, J. C., T. F. Jenkins, S. Thiboutot, G. Ampleman, S. Thiboutot, H. Colby, A. D. Hewitt, et al. 2006. "Distribution and Fate of Energetics on DoD Test and Training Ranges: Report 6.” ERDC Technical Report. Vicksburg, MS: U.S. Army Engineer Research and Development Center.

Picatinny Public Affairs. (2010) Army Approves Safer Explosive to Replace TNT. https://www.army.mil/article/43553/army_approves_safer_explosive_to_replace_tnt. (Accessed 27 Jun 2019).

Roos, B. 2007. The Characterization of IM Explosive Candidates for TNT Replacement. Presented at the 2007 Insensitive Munitions and Energetic Materials Technology Symposium, Miami, FL.

Russell, A. L., J. M. Seiter, J. G. Coleman, B. Winstead, and A. J. Bednar. 2014. Analysis of Munitions Constituents in IMX Formulations by HPLC and HPLC-MS. Talanta, 128, 524-530.

Taylor, S., A. Hewitt, J. Lever, C. Hayes, L. Perovich, P. Thorne, and P. Daghalin. 2004. TNT Particle Size Distribution for Detonated 155-mm Howitzer Rounds. Chemosphere 55, 357-367.

Thurman, E. M., and I. Ferrar. 2012. Adapting EPA Method 8330 for Analysis of Explosives in Water to SPE and LC/MS/MS. Agilent Technologies Application Note, 5991-0676EN.

US Environmental Protection Agency. 1996. Method 8332 (SW-846): Nitroglycerine by High Performance Liquid Chromatography, Revision o. Washington, D.C. 
US Environmental Protection Agency. 2006. Method 8330B (SW-846): Nitroaromatics, Nitroamines, and Nitrate Esters by High Performance Liquid Chromatography (HPLC), Revision 2. Washington, D.C.

US Environmental Protection Agency. 2007. Method 3535A (SW-846): Solid-Phase Extraction (SPE), Revision 1. Washington, D.C.

US Environmental Protection Agency. 2007. Method 8321B (SW-846): SolventExtractable Nonvolatile Compounds by High-Performance Liquid Chromatography/Thermospray/Mass Spectrometery (HPLC/TS/MS) or Ultraviolet (UV) Detection, Revision 2. Washington, D.C.

US Environmental Protection Agency. 2014. SW-846, Chapter 4: Organic Analytes, Revision 5, Section 4.1 Sampling Considerations, pp 11. Washington, D.C.

Walsh, M. E. 2001. Determination of Nitroaromatic, Nitramine, and Nitrate Ester Explosives in Soil by Gas Chromatography and an Electron Capture Detector. Talanta, 54, 427-438.

Walsh, M. E. 2016. Analytical Methods for Detonation Residues of Insensitive Munitions. Journal of Energetic Materials, 34, 76-91.

Walsh, M. E., and T. F. Jenkins. 1990. Liquid Chromatographic Separation of 2,4,6Trinitrotoluene and Its Principal Reduction Products. Analytica Chimica Acta, $231,313-315$.

Walsh, M. R., M. E. Walsh, C. A. Ramsey, S. Thiboutot, G. Ampleman, E. Diaz, and J. E. Zufelt. 2014. Energetic Residues from the Detonation of IMX-104 Insensitive Munitions. Propellants, Explosives, Pyrotechnics, 39, 243-250.

Xu, X., A. M. van de Craats, E. M. Kok, P. C. A. M. de Bruyn. 2004. Trace Analysis of Peroxide Explosives by High Performance Liquid Chromatography-Atmospheric Pressure Chemical Ionisation-Tandem Mass Spectrometry (HPLC-APCI-MS/MS) for Forensic Applications. J. Forensic Sci, 49 (6): 1-7. 


\section{List of Acronyms}

\begin{tabular}{|c|c|}
\hline $\mathrm{ACN}$ & acetonitrile \\
\hline AEC & anion exchange capacity \\
\hline 4-Am-2,6-DNT & 4-amino-2,6-dinitrotoluene \\
\hline 2-Am-4,6-DNT & 2-amino-4,6-dinitrotoluene \\
\hline ASTM & American Society for Testing and Materials \\
\hline BIP & blow in place \\
\hline CEC & cation exchange capacity \\
\hline $\mathrm{CH}_{3}$ & methyl \\
\hline Comp-B & Composition-B \\
\hline CRREL & Cold Regions Research and Engineering Laboratory \\
\hline 3,5-DNA & 3,5-dinitroaniline \\
\hline DNAN & 2,4-dinitroanisole \\
\hline 1,2-DNB & 1,2-dinitrobenzene \\
\hline 1,3-DNB & 1,3-dinitrobenzene \\
\hline 2,4-DNP & 2,4-dinitrophenol \\
\hline 2,4-DNT & 2,4-dinitrotoluene \\
\hline 2,6-DNT & 2,6-dinitrotoluene \\
\hline DoD & Department of Defense \\
\hline EL & Environmental Laboratory \\
\hline ER & Environmental Restoration \\
\hline ERDC & Engineer Research and Development Center \\
\hline ESTCP & Environmental Security Technology Certification Program \\
\hline FA & formic acid \\
\hline GAC & granular activated carbon \\
\hline $\mathrm{H}$ & hydrogen atom, proton \\
\hline HOAc & acetic acid \\
\hline $\mathrm{HCl}$ & hydrochloric acid \\
\hline HMX & octahydro-1,3,5-7-tetranitro-1,3,5,7-tetrazocine \\
\hline HPLC & high-performance liquid chromatography \\
\hline IM & insensitive munition \\
\hline LCL & lower control limit \\
\hline LDR & linear dynamic range \\
\hline MDL & method detection limit \\
\hline $\mathrm{MeOH}$ & methanol \\
\hline meq & mole equivalent \\
\hline MS & mass spectrometer or mass spectrometry \\
\hline NB & nitrobenzene \\
\hline ND & not detected \\
\hline$N G$ & nitroglycerine \\
\hline 2-NP & 2-nitrophenol \\
\hline 4-NP & 4-nitrophenol \\
\hline NQ & nitroguanidine \\
\hline
\end{tabular}




\begin{tabular}{|c|c|}
\hline 2-NT & 2-nitrotoluene \\
\hline 3-NT & 3-nitrotoluene \\
\hline 4-NT & 4-nitrotoluene \\
\hline NTO & 3-nitro-1,2,4-triazol-5-one \\
\hline o-NBA & ortho-nitrobenzoic acid \\
\hline PA & picric acid \\
\hline PETN & pentaerythritol tetranitrate \\
\hline PTFE & polytetrafluoroethylene \\
\hline QSM & quality systems manual \\
\hline RDX & hexahydro-1,3,5-trinitro-s-triazine \\
\hline SERDP & Strategic Environmental Research and Development Program \\
\hline SPE & solid phase extraction \\
\hline SE & solvent extraction \\
\hline Tetryl & $N$-methyl- $N$-(2,4,6-trinitrophenyl) nitramide \\
\hline TFA & trifluoroacetic acid \\
\hline TIC & total ion chromatogram \\
\hline $1,3,5-T N B$ & 1,3,5-trinitrobenzene \\
\hline 2,4,6-TNT & 2,4,6-trinitrotoluene \\
\hline TNT & trinitrotoluene \\
\hline TDS & total dissolved solids \\
\hline TOC & total organic carbon \\
\hline UCL & upper control limit \\
\hline UL & upper limit \\
\hline USEPA & United States Environmental Protection Agency \\
\hline UV & ultraviolet \\
\hline UXO & unexploded ordnance \\
\hline $\mathrm{v} / \mathrm{v}$ & volume/volume \\
\hline $\mathrm{vol} / \mathrm{vol}$ & volume/volume \\
\hline
\end{tabular}




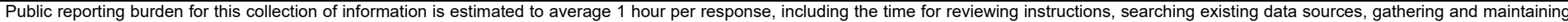

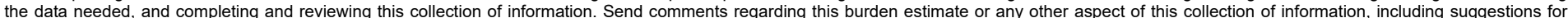

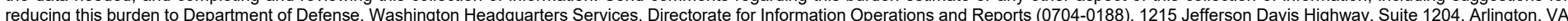

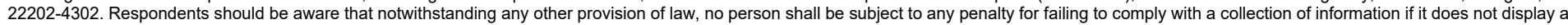
currently valid OMB control number. PLEASE DO NOT RETURN YOUR FORM TO THE ABOVE ADDRESS.
1. REPORT DATE (DD-MM-YYYY) 2. REPORT TYPE
August 2021
Final Technical Report

\section{TITLE AND SUBTITLE}

Preparative, Extraction, and Analytical Methods for Simultaneous Determination of Legacy and Insensitive Munition (IM) Constituents in Aqueous, Soil or Sediment, and

Tissue Matrices

\section{AUTHOR(S)}

\section{DATES COVERED (From - To)}

5a. CONTRACT NUMBER

5b. GRANT NUMBER

5c. PROGRAM ELEMENT NUMBER

5d. PROJECT NUMBER

Rebecca A. Crouch, Jared C. Smith, Bobbi S. Stromer, Christian T. Hubley, Samuel Beal, Guilherme R. Lotufo, Afrachanna D. Butler, Michelle T. Wynter, Dale A. Rosado,

Amber L. Russell, Jessica G. Coleman, Jay L. Clausen, and Anthony J. Bednar

\section{PERFORMING ORGANIZATION NAME(S) AND ADDRESS(ES)}

U.S. Army Engineer Research and Development Center

Environmental Laboratory

3909 Halls Ferry Road

Cold Regions Research and Engineering Laboratory

72 Lyme Road

Vicksburg, MS 39180

Hanover, NH 03755

9. SPONSORING / MONITORING AGENCY NAME(S) AND ADDRESS(ES)

Strategic Environmental Research and Development Program

4800 Mark Center Drive, Suite 16F16

Alexandria, VA 22350-3605

\section{5e. TASK NUMBER}

5f. WORK UNIT NUMBER

8. PERFORMING ORGANIZATION REPORT NUMBER

ERDC TR-21-12

10. SPONSOR/MONITOR'S ACRONYM(S)

SERDP

11. SPONSOR/MONITOR'S REPORT NUMBER(S)

\section{DISTRIBUTION / AVAILABILITY STATEMENT}

Approved for public release; distribution is unlimited.

\section{SUPPLEMENTARY NOTES}

Funded under MIPR W74RDV70604798.

\section{ABSTRACT}

No standard method exists for determining levels of insensitive munition (IM) compounds in environmental matrices. This project resulted in new methods of extraction, analytical separation and quantitation of 17 legacy and 7 IM compounds, daughter products of IM, and other munition com-pounds absent from USEPA Method 8330B. Extraction methods were developed for aqueous (directinjection and solid-phase extraction [SPE]), soil, sediment, and tissue samples using laboratory-spiked samples. Aqueous methods were tested on 5 water sources, with 23 of 24 compounds recovered within DoD QSM Ver5.2 limits. New solvent extraction (SE) methods enabled recovery of all 24 compounds from 6 soils within QSM limits, and a majority of the 24 compounds were recovered at acceptable levels from 4 tissues types. A modified chromatographic treatment method removed analytical interferences from tissue extracts. Two orthogonal high-performance liquid chromatography-ultraviolet (HPLC-UV) separation methods, along with an HPLC-mass spectrometric (HPLC-MS) method, were developed. Implementing these new methods should reduce labor and supply costs by approximately 50\%, requiring a single extraction and sample preparation, and 2 analyses rather than 4 . These new methods will support environmental monitoring of IM and facilitate execution of risk-related studies to determine long-term effects of IM compounds.

\section{SUBJECT TERMS}

Chemical agents (Munitions), Explosives--Environmental aspects, Environmental monitoring, Bioaccumulation, Soils-Testing, Water-Testing, Tissues--Testing

\section{SECURITY CLASSIFICATION OF:}

\section{a. REPORT}

Unclassified

\section{b. ABSTRACT}

Unclassified

\section{c. THIS PAGE}

Unclassified
17. LIMITATION OF ABSTRACT

SAR
18. NUMBER OF PAGES

110 19a. NAME OF RESPONSIBLE PERSON

19b. TELEPHONE NUMBER (include area code) 